Государственное бюджетное образовательное учреждение высшего профессионального образования «Курский государственный медицинский университет»

Министерства здравоохранения Российской Федерации

Т.В. Кубрушко, В.А. Коробкин, Е.В. Милова, М.А. Лунёв, С.С. Хайн

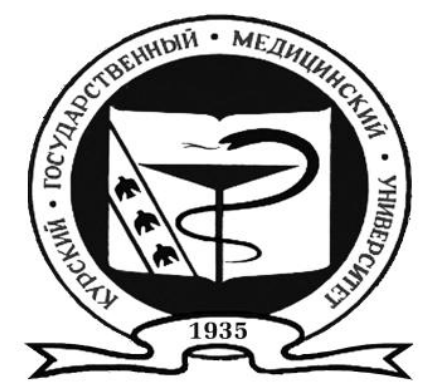

\title{
СИНДРОМНО-СХОДНЫЕ ЗАБОЛЕВАНИЯ ОРГАНОВ ПОЛОСТИ РТА И ЧЕЛЮСТНО-ЛИЦЕВОЙ ОБЛАСТИ
}

\section{Учебное пособие}

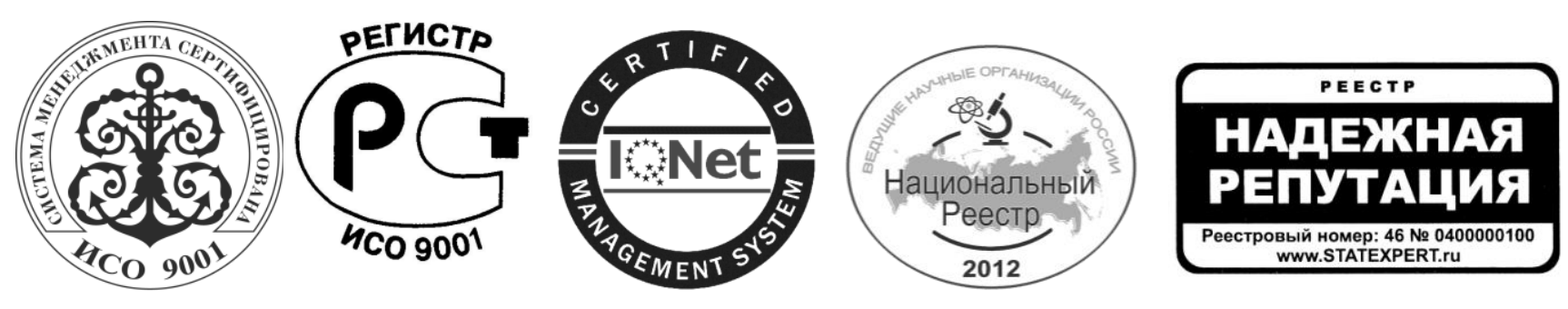

Курск - 2013 
Кубрушко Т.В., Коробкин В.А., Милова Е.В., Лунёв М.А., Хайн С.С. Синдромно-сходные заболевания органов полости рта и челюстно-лицевой области. Курск: ГБОУ ВПО КГМУ Минздрава России - 2013 г.-172с

В пособии освещены вопросы прикладной анатомии челюстнолицевой области, знания которой так необходимы для диагностического поиска синдромно-сходных заболеваний на врачебном приёме врача стоматолога общей практики. Приведены схемы ООД при диагностическом поиске синдромно-сходных заболеваний - острая боль, нарушение конфигурации лица, заболевания СОПР. Согласно рекомендациям ВОЗ и на основе МКБ-10 проведена диагностика заболеваний органов полости рта. Описаны методы доказательной медицины при применении математических индексов во время обследования органов полости рта. В пособии отмечено, что в зубочелюстной системе чаще всего наблюдается сочетание различных заболеваний и их осложнений, знание которых способствует формированию системного клинического мышления врача-стоматолога общей практики, позволяет врачу обнаружить болезнь до клинических проявлений.

( Кубрушко Т.В., Коробкин В.А., Милова Е.В.КГМУ, 2013

(C) ГБОУ ВПО КГМУ Минздрава России, 2013 
Содержание

Предисловие.......................................... 2

Введение.......................................... 5

Синдромно-сходные заболевания органов полости рта и 9 челюстно-лицевой области. ...

Раздел I. Прикладная анатомия челюстно-лицевой области..... 9

1.1. Анатомо-физиологические особенности развития че- 9 люстно-лицевой области. Эмбриогенез.

1.2. Анатомо-физиологические особенности верхней и нижней челюсти...................................... 11

1.3. $\quad$ Зубные ряды...................................... 16

1.4. $\quad$ Виды физиологического и аномального прикуса......... 20

1.5. Мышцы челюстно-лицевой области...................... 23

1.6. Анатомо-физиологические особенности височно- 27 нижнечелюстного сустава.............................

1.7. Антропометрические закономерности................... 29

1.8 Высота нижнего отдела лица............................ 30

Раздел II. Диагностический поиск синдромно-сходных заболеваний...................................................... 32

2.1. Острая боль...................................... 34

2.2. Tриггерные точки крыловидной, височной, жевательной мышц................................................. 35

2.3 Парестезии........................................... 37

2.4 Нарушения конфигурации лица: 38

Острые одонтогенные воспалительные заболевания.

2.5 Травматические повреждения челюстно-лицевой обла- 45 сти

2.6 Опухолевые процессы в челюстно-лицевой области...... 49

2.7 Морфологические элементы при заболеваниях слизи- 50 стой оболочки полости рта, языка, губ.

Раздел III. Методы обследования при заболеваниях челюстно- 66 лицевой области...........................................

3.1. Субъективные методы обследования челюстно-лицевой 67 области..................................................

3.2. Объективное обследование челюстно-лицевой области. 72 Рекомендации. ВОЗ Внеротовая область.

3.3. Околоротовые и внутриротовые мягкие ткани........... 79

Раздел IV Зубы и ткани пародонта................................. 83

4.1. Некариозные поражения................................ 98

4.2. Кариес зубов..................................... 99

4.3. Заболевания пародонта. Математические индексы в 102 стоматоло- 
гии.

4.4. Способ определения интенсивности заболеваний тка- 106 ней пародонта

4.5.

Рецессия десны

Раздел V Частичное и полное отсутствие зубов.................... 109

5.1.

Деформаций зубных рядов и прикуса.

5.2 .

Обследование больного при полном отсутствии зубов...

6. Клинический диагноз

Деонтологические аспекты на амбулаторном приёме врача стоматолога

8.

Первичная документация на амбулаторном приёме вра- 125

9. ча стоматолога

10. Заключение

10.1 . Приложение Европей Приложение Международная классификация стомато- 136 логических болезней на основе МКБ-10.

10.3 . Приложение Рентгенодиагностика заболеваний органов 166 полости рта и челюстно-лицевой области 
«Нужно, конечно, стремиться к техническому

прогрессу в медицине, но так, чтобь

не растерять драгоченные качества врача -

сердечность, любовь к людям, человечность.

Несмотря на техническое вооружение, медичина не перестаёт быть медичиной личности».

А.Ф. Билибин

В повседневной практике врачу дано увидеть лишь внешние, иногда весьма скудные и трудноразличимые заболевания органов полости рта и челюстно-лицевой области и их проявления. В других случаях проявления болезни, напротив, оказываются множественными, общая картина заболевания становится неопределённой. Врачу необходимо отличить не только болезненное состояние от здоровья, но и определить форму, тяжесть и стадию развития патологии.

Современная стоматология характеризуется тесным сближением всех ее разделов с основными направлениями общей клинической медицины, изучающей этиологию, патогенез болезней и повреждений твёрдых тканей зубов, тканей пародонта, слизистой полости рта, языка, губ, деформаций и повреждений челюстно-лицевой области и разрабатывающей методы их диагностики, лечения и профилактики.

Общеизвестно, что подавляющая часть населения обращается к стоматологу только при возникновении какого-либо стоматологического заболевания (заболевания твёрдых тканей зуба, пародонта, СОПР, ВНЧС, частичная потеря зубов и др.). Обращения, которые сопровождаются симптомами острого заболевания, требуют от врача проведения неотложных, нередко радикальных мероприятий. Стоматологическое состояние у различных больных находится в прямой зависимости от его стоматологической осведомлённости, мотивации на профилактику и лечение развившейся патологии.

Основным направлением реформирования здравоохранения в России является поэтапный переход на работу по принципу врача общей практики. В приказе МЗ РФ № 337 от 27.08.1999 г. «О номенклатуре специальностей в учреждениях здравоохранения Российской Федерации» была введена новая специальность «Стоматология», а в дальнейшем согласно приказу МЗ и СР РФ № 553 от 20.08.2007 г. и № 112н от 11.03.2008 г. - «Стоматология общей практики». Врач-стоматолог общей практики обязан обладать суммой знаний, которые необходимы для обеспечения своевременной диагностики, лечения и профилактики широкого круга заболеваний, независимо от пола и возраста пациента. Возникает необходимость в подготовке врача, который сможет обеспечить и отвечать за конечный результат - здоровье конкретного человека и членов его семьи. Профессиональ- 
ная подготовка врача по специальности «Стоматология общей практики» должна предусматривать оптимальный объём теоретических знаний и практических навыков, необходимых в повседневной работе, с учетом специфики оказания стоматологической помощи широкому кругу пациентов и разнообразия видов стоматологической помощи.

В своей профессиональной деятельности стоматолог должен руководствоваться не только принципом «не навреди», но и стараться предотвращать заболевания полости рта. 


\section{ВВЕДЕНИЕ}

Профессиональные функции врача должны выполняться в соответствии с принципом «не навреди». На протяжении тысячелетий к врачу обращались с различными проблемами, которые тем или иным образом связаны со здоровьем и общим самочувствием пациента, когда причины возникновения большинства заболеваний не были известны. Постепенно выявлялись и описывались различные симптомы, характерные для тех или иных заболеваний.

Развитие и проявление патологических процессов (травма, инфекция, опухолевые процессы) в челюстно-лицевой области находятся в прямой зависимости от строения и характера окружающих органов и тканей. Знания прикладной анатомии способствуют диагностическому поиску синдромно-сходных заболеваний челюстно-лицевой области: острая боль, нарушение конфигурации лица, заболевания СОПР. Математические индексы, применяемые во время проведения обследования органов полости рта, основаны на методах доказательной медицины.

Для правильного проведения диагностического процесса необходимо применять на практике все методы исследований, уметь фиксировать и правильно интерпретировать обнаруженные при этом симптомы. Знать основные и специфические признаки заболеваний зубочелюстной системы, их классификации, владеть особенностями врачебного мышления на этапах обследования, особенно при анализе и синтезе полученных субъективных и объективных данных для установления этиологии заболевания, его патогенеза и, наконец, для постановки диагноза и определения метода лечения и врачебной тактики.

В профессиональной практике врача-стоматолога оказание неотложной помощи связано, прежде всего, с проявлением боли, которая проявляется в виде гетеротопической, психогенной, кардиологической и дентальной боли.

Острое воспаление в челюстно-лицевой области является состоянием, требующим оказания неотложной помощи из-за болевого синдрома и дальнейшего распространения воспалительного процесса. Знания патоморфологических и клинических проявлений позволяют в профессиональной деятельности врача-стоматолога своевременно выбрать метод лечения, снижающий болевой синдром и препятствующий дальнейшему распространению воспалительного процесса.

Этиологическими факторами острой боли являются: одонтогенный воспалительный процесс в пульпе зуба, периодонте, неправильно изготовленный мостовидный протез или кламмер, завышение поставленной пломбы или коронки, а также в результате перегрузки (хронической травмы) при частичном отсутствии зубов.

Острая боль локализованного характера в слизистой оболочке может быть обусловлена травмой при глубоком прикусе или при частичной потере зубов, осложненной глубоким резцовым перекрытием, дистальным 
смещением нижней челюсти и снижением окклюзионной высоты, а также при супраокклюзионном смещении одного или группы зубов (феномен Попова-Годона), при снижении окклюзионной высоты. Боль, жжение, покалывание, пощипывание разлитого характера обусловлены механической травмой, аллергической реакцией на базисный материал при пользовании съемным протезом, заболеваниями крови или желудочно-кишечного тракта.

Ряд симптомов являются признаками различных заболеваний. В рассказе больного часто превалируют субъективно оцениваемые и наиболее важные с его точки зрения явления, которые, доминируя в физиологическом и психологическом восприятии, могут вуалировать другие сложные заболевания зубочелюстной системы, но протекающие без субъективных для больного ощущений. Важно помнить, что в зубочелюстной системе чаще всего имеется сочетание различных заболеваний и их осложнений.

Независимо от жалоб больного и клинических симптомов необходимо исследовать всю зубочелюстно-лицевую область и каждый ее орган, должно быть оценено общее состояние организма, уточнены сопутствующие общесоматические заболевания. Достигнуть этого можно, применяя так называемый методический тип диагностического исследования.

Медицина XXI века - это медицина превентивная, сохраняющая и оберегающая здоровье человека. Превентивная медицина с целью тщательного сканирования рисков заболевания, использует все известные методы диагностики и позволяет обнаружить болезнь до ее клинических проявлений и вовремя принять предупредительные меры. Превентивная медицина является врачебным искусством, которым не смогут овладеть все врачи, поэтому в настоящее время актуальным является разработка диагностических систем, которые позволят сделать диагностику доступной для многих врачей. Стране и обществу необходима новая медицинская научно-практическая школа для распространения системного клинического мышления.

На основании вышеизложенного, авторами предложен диагностический поиск синдромно-сходных заболеваний в виде схем ориентировочных основ действия. В пособии отмечено, что наличие ряда симптомов являются признаками различных заболеваний, что и отражено в схеме ориентировочной основы действий «Методы обследования с целью диагностики заболеваний органов полости рта».

Рассмотрены очень важные направления в диагностическом поиске синдромно-сходных заболеваний такие как, схемы ориентировочной основы действия «Методы обследования с целью диагностики заболеваний слизистой полости рта, языка, губ» и «Диагностические признаки глоссалгии, глоссодинии и глоссита». Именно заболевания слизистой полости рта, языка, губ являются первыми признаками соматических заболеваний организма, знания которых могут способствовать ранней диагностике злокачественных новообразований. 
В условиях целостного организма не может быть изолированных органов и систем. Врачу не только по специальности «Стоматология общей практики», но и специальности «Лечебное дело», необходимо иметь представление о взаимосвязи и взаимообусловленности как физиологических, так патологических процессов, протекающих в организме. Известно, что наличие хронических свищевых ходов при остеомиелите и периостите челюсти является противопоказанием для проведения «чистых» плановых операций в хирургической клинике, так как одонтогенная инфекция может явиться причиной гнойного осложнения в послеоперационном периоде. Поэтому врачу, окончившему лечебный или педиатрический факультет, необходимы знания и умения обследования больных для своевременной диагностики травм челюстно-лицевой области, кровотечения после удаления зуба, больных с флегмонами челюстно-лицевой области и т.д.

Стоматолог может устранить или, по крайней мере, снизить боль. Он может способствовать достижению здоровья полости рта, улучшить эстетические характеристики зубов и лица. Однако он не может ни пообещать, ни тем более обеспечить достижения состояния полного телесного, психического и социального благополучия.

Коллектив авторов надеется, что предложенное методическое пособие позволит сформировать единый комплексный подход в методах обследования больных в конкретной клинической ситуации.

\section{СИНДРОМНО-СХОДНЫЕ ЗАБОЛЕВАНИЯ.}

\section{РАЗДЕЛ 1. ПРИКЛАДНАЯ АНАТОМИЯ ЧЕЛЮСТНО-ЛИЦЕВОЙ ОБЛАСТИ \\ 1.1. АНАТОМО-ФИЗИОЛОГИЧЕСКИЕ ОСОБЕННОСТИ РАЗВИ- ТИЯ ЧЕЛЮСТНО-ЛИЦЕВОЙ ОБЛАСТИ. ЭМБРИОГЕНЕЗ}

Стоматология - это раздел медицинской науки и практики, который решает проблемы профилактики, распознование и лечение одних из самых распостранённых патологий, какими являются стоматологические заболевания. На амбулаторном приеме врачу дано увидеть лишь внешние, иногда весьма скудные и трудноразличимые заболевания и их проявления. В других случаях проявления болезни, напротив, оказываются множественными, общая картина заболевания становится неопределённой, необходимо отличить не только болезненное состояние от здоровья, но и определить форму, тяжесть и стадию развития патологии.

Для понимания особенностей проявления патологических процессов (травма, инфекция, опухолевые процессы) в челюстно-лицевой области, развитие и проявление которых находятся в прямой зависимости от строения и характера окружающих органов и тканей, необходимы знания не только клинических дисциплин, но и знания анатомии, физиологии, гистологии, микробиологии и др. 
Такое направление отмечено в работах Е.В. Боровского, Т.Ф. Виноградовой, А.И. Грудянова, В.Ю. Курлянского, В.Н. Копейкина, А.А. Колесова, Г.Д. Овруцкого, Т.Г. Робустовой, А.И. Рыбакова, Л.Л. Параскевич, М.М. Соловьева, А.А. Тимофеева и др.

Зубочелюстная система - совокупность органов и тканей, взаимосвязанных анатомически и функционально, выполняющих различные, но соподчиненные функции. В нее входят:

- $\quad$ твердые ткани - кости лицевого скелета, включая верхнюю и нижнюю челюсти;

- $\quad$ зубы, образующие зубные ряды - система органов, предназначенная для откусывания, дробления и размельчения пищи;

- височно-нижнечелюстной сустав (два сустава) - подвижное соединение нижней челюсти с височной костью черепа;

- $\quad$ жевательные и надподъязычные мышцы, обеспечивающие пространственное перемещение нижней челюсти по отношению к неподвижной верхней челюсти;

- $\quad$ комплекс тканей, выполняющих функцию захватывания пищи, формирования и глотания пищевого комка и функцию речиэто мимические мышцы, губы, щеки, нёбо, язык

- $\quad$ слюнные железы, предназначенные для смачивания и первичной ферментативной обработки пищи.

Воздействию неблагоприятных внутренних и внешних факторов, подвержены в онтогенезе мозговой и лицевой череп, которые часто приводят к нарушению развития отдельных органов и систем в лицевой области. Профилактика и лечение этих нарушений базируются на полном представлении последовательности этапов формирования и развития лицевой области головы человека.

В процессе развития мозговой и лицевой скелет, мускулатура и органы полости рта в течение миллионов лет прошли этапы формирования, совершенствования и видоизменений. Под влиянием воздействия внешней среды всё это происходило в результате естественного отбора, изменчивости, наследственности и выживаемости, мозговой и лицевой череп подвергался формированию и перестройке. Основной особенностью является непрерывное морфологическое и функциональное их развитие и взаимное влияние друг на друга. В лицевой области развиваются и перестраиваются челюстные кости, развиваются мышцы и другие органы полости рта. Лицевой череп и органы полости рта продолжают расти после рождения, причём рост костей головы происходит неравномерно. Кости лицевого скелета развиваются быстрее. Рост челюстей наиболее выражен в период формирования и прорезывания молочных и постоянных зубов, что обусловливает изменения в пропорциональном соотношении лицевого и мозгового черепа. У новорождённого лицевая часть головы представляет собой лишь незначительный придаток к мозговой части. У 6-летнего ребёнка лицо равно половине мозговой части, а после 6 лет значительно опережает рост моз- 
говой части. У взрослого высота лица соотносится к высоте мозгового черепа 2:1.

Развитие лица и челюстей в эмбриональном периоде происходит в определённой последовательности. Развивающиеся органы закладываются в известном порядке в течение определённого периода, развитие одних из них связано с развитием других. Образование лицевой части головы происходит за счёт разрастания жаберных дуг. Лицевая часть головы начинает оформляться с 2-й недели эмбрионального развития и формируется из 7 отростков жаберной дуги: 2 носовых, 2 верхнечелюстных, 2 нижнечелюстных и лобного.

В 12-дневном эмбрионе, длина которого равна 2,5 мм, появляется небольшое углубление (первичный рот). Ротовое отверстие к концу первого месяца ограничивается снизу нижнечелюстными отростками, сверху и в наружном отрезке - верхнечелюстными, сверху и по средней линии - носовыми отростками. На втором месяце развития эмбриона вдоль всего края верхнего и нижнего челюстных отростков появляется утолщение покровного эпителия, выступающее в полость рта в виде шнурка. Размножаясь по мере развития эмбриона, покровный эпителий постепенно приобретает дугообразную форму и разделяется на две пластинки - наружную (щёчногубную) и внутреннюю (зубную). Из внутренней пластинки формируются зубы. Рост лица усиливается, начиная с 5 недели, к концу 2 месяца лицо принимает уже вид человека: наружный носовой отросток превращается в крыло носа, нижняя часть внутреннего носового отростка, срастаясь с верхнечелюстными отростками, образуют верхнюю челюсть. Из внутреннего носового отростка развивается межчелюстная кость в нёбные отростки, срастающиеся между собой и с крылонёбными отростками.

Ограничение полости рта от полости носа происходит на 3 месяце, когда заканчивается формирование твёрдого и мягкого нёба. Нёбные отростки срастаются к концу 8-й недели, на 9-й неделе уже имеется свод твёрдого нёба, а на 12-й образуется свод мягкого нёба.

При нарушениях эмбриональных процессов развития лица в период первых двух месяцев возникают уродства в виде так называемой заячьей губы (labium leporinum) и волчьей пасти (faux lupinum).

Лицевой скелет состоит из парных неподвижных костей - верхней челюсти, скуловых, нёбных и подвижной кости - нижней челюсти. Костные швы между костями лицевого скелета и основанием черепа более податливы, чем сами кости. Поэтому переломы проходят часто по линии костных швов. 


\section{2. Анатомо-физиологические особенности верхней и нижней челюсти. Верхняя челюсть}

Верхняя челюсть состоит из тела челюсти и четырёх отростков: лобного, нёбного, скулового и альвеолярного. Тело челюсти содержит полость - sinus maxillaries, или гайморову пазуху, клетки решётчатого лабиринта, лобные пазухи. Стенки тела верхней челюсти представлены на большей части её поверхности тонкими костными пластинками, содержащими небольшой слой костномозгового вещества. Тело верхней челюсти соединяется с телом противоположной одноимённой кости по средней линии костным швом. При помощи отростков - нёбного, лобного и скулового верхняя челюсть соединяется с костями черепа, со скуловой костью. В альвеолярном отростке расположены лунки зубов. Следует отметить, что верхушки корней моляров (особенно первых), премоляров в некоторых случаях располагаются интимно к слизистой дна гайморовой пазухи, что создаёт возможность возникновения в гайморовой пазухе воспалительного процесса. Кроме того, при удалении указанных зубов возможна перфорация дна пазухи с образованием хронического свищевого хода.

На передней стенки тела верхней челюсти имеется отверстие (foramen infraorbitale) нижнеглазничного канала - место выхода сосудистонервного пучка.

Анатомо-топографические особенности верхней челюсти предопределяют характер патологических процессов, развивающихся в ней. Остеомиелит верхней челюсти чаще бывает ограниченным, так как тонкая кортикальная пластинка не является серьёзным препятствием для проникновения экссудата из внутрикостного очага воспаления. Этому же способствует относительно малое содержание в челюсти костного мозга и рассыпной тип кровеносных сосудов, ограниченный масштаб поражения кости.

Форма верхней челюсти и структура кости зависят от степени развития зубной системы и гайморовой полости. Рост альвеолярных отростков верхней челюсти находится в полной зависимости от развития заложенных в ней зубных зачатков, которые отделены от полости рта тонким слоем тканей. С возрастом гайморова полость постепенно становится шире. Она непрерывно оттесняет альвеолярный отросток книзу от дна глазницы. На 3-м и 4-м году жизни гайморова полость переходит за границы canalis infraorbitalis, а кзади подходит к альвеоле первого моляра.

Верхняя челюсть представляет собой парную кость, состоящую из симметричных половин. Обе половины челюсти соединяются между собой и другими костями лицевого скелета костными швами.

Часть верхней челюсти, рассматриваемую в полости рта, можно разделить на три отдела: вести булярный, альвеолярный и небный.

Различают ряд анатомических образований: переходную складку слизистой оболочки, уздечку верхней губы и боковые слизистые оболочки 
складки. Переходная складка образуется на месте перехода слизистой оболочки с альвеолярного отростка на верхнюю губу и щеки. В месте перехода слизистой оболочки на верхнюю губу и щеки имеется хорошо выраженный подслизистый слой. Уздечка верхней губы (frenulum labii superioris) располагается на альвеолярном отростке по средней линии.

У взрослого она отстоит от него на расстоянии 5-8 мм.

Боковые слизистые оболочки складки (plicae buccalis) располагаются в области премоляров. Альвеолярный отросток с вестибулярной стороны покрыт плотной слизистой оболочкой с маловыраженным подслизистым слоем.

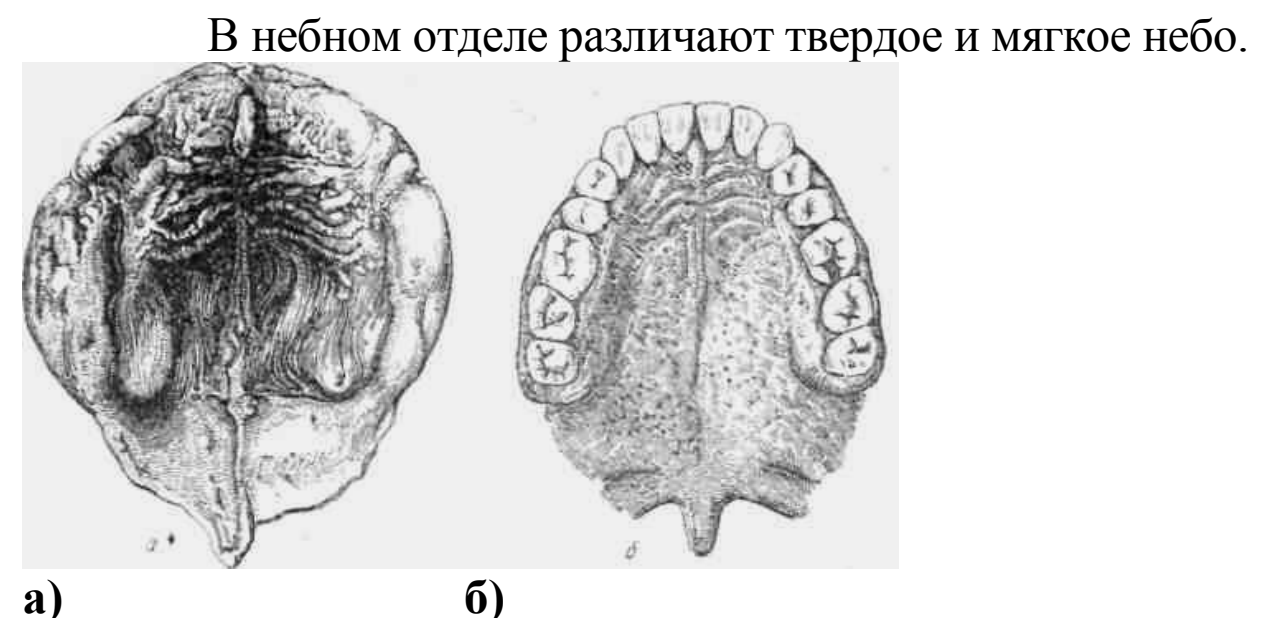

Рис. 1. Твердое и мягкое небо: а) у новорожденного; б) у взрослого.

Твердое небо (palatum durum) состоит из межчелюстной кости, небных отростков и горизонтальной части небной кости. Межчелюстная кость и альвеолярная часть небных отростков образует оральную часть альвеолярного отростка. Задний край твердого неба имеет вид двух дуг, соединенных внутренними концами в виде выступа - задней носовой ости (spina nasalis posterior).Твердое небо имеет ряд каналов и канальцев, открывающихся на ротовой его поверхности. Через них выходят сосуды и нервы. Ротовая поверхность твердого неба представляется неровной, с наличием возвышений, углублений и мелких борозд для сосудов и нервов, слизистая оболочка, покрывающая твердое небо, чрезвычайно плотная. По мере роста и развития верхней челюсти и альвеолярного отростка твердое небо меняет свою конфигурацию: оно плоское у плода и имеет высокий купол у взрослого (рис.1). После потери зубов твердое небо становится вновь плоским.

Слизистая оболочка твердого неба в передней трети плотно сращена с надкостницей. В области небного шва она тонкая и чувствительная к давлению. В передней трети слизистая оболочка представляется в виде валикообразных возвышений (rugae palatinae). В средней и задней частях твердого неба по сторонам от шва имеется выраженный подслизистый слой, жировая и железистая ткань. Мягкое небо спереди граничит с задним краем твердого неба, по сторонам связано с боковыми стенками глотки, сзади оканчивается свободным краем, повторяющим фигуру заднего края костей твердого неба. 
В строении верхней челюсти как функционального образования рассматривают контрфорсы (рис. 2). Контрфорсы - это устои, воспринимающие жевательное давление и удары, возникающие во время смыкания зубных рядов. Различают четыре контрфорса:

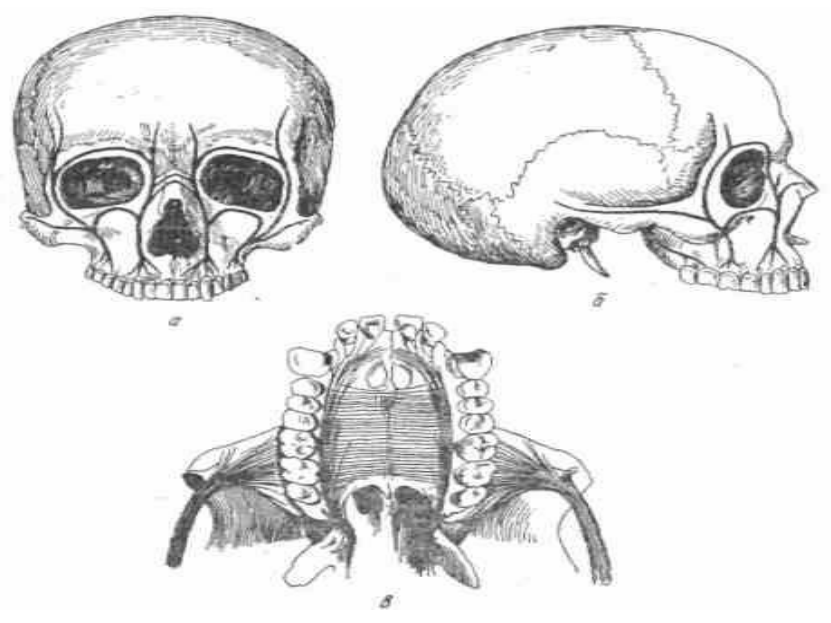

Рис. 2. Контрфорсы. Первый - лобно-носовой контрфорс.

Второй - скуловой контрфорс. Третий - крыло-небный контрфорс. Четвертый - небный, контрфорс.

Горизонтальным контрфорсом является небный отросток, который противостоит боковым силам и рассредотачивает жевательное давление по высоте кости.

К вертикальным контрфорсам относятся: 1) лобный контрфорс; 2) скуловой контрфорс; 3) медиальная стенка гайморовой полости - пристеночный медиально-гайморовый контрфорс: 4) латеральная стенка (подвисочная) гайморовой полости - пристеночный гайморово-латеральный контрфорс; 5) сошник - сошниковый контрфорс.

Все вертикальные устои при акте откусывания и размалывания пищи работают на сжатие. Местами приложения сил в вертикальных устоях являются альвеолярный и небный отростки, а местами опоры - кости лицевого и мозгового черепа.

\section{Нижняя челюсть}

Нижняя челюсть является непарной костью; в ней различают тело, две ветви челюсти. Кроме альвеолярного отростка, нижняя челюсть имеет на каждой стороне суставной и венечный отросток. Альвеолярный отросток располагается по верхнему краю вдоль тела челюсти. Суставной отросток заканчивается суставной головкой. Между суставным и венечным отростком ветви челюсти образуется полулунная вырезка. Движение нижней челюсти осуществляется при помощи височно-нижнечелюстного сустава, который состоит из суставной головки, суставной ямки височной кости, хрящевого мениска, суставной сумки и связочного аппарата.

На внутренней поверхности ветви нижней челюсти располагается отверстие (foramen mandibulare), которое является началом нижнечелюстно- 
го канала, где проходит сосудисто-нервный пучок (нижнеальвеолярные артерия, вена и нерв). На уровне премоляров с вестибулярной стороны нижнечелюстной канал открывается подбородочным отверстием (foramen mentale), из которого выходит артерия, вена и нерв. В отличие от верхней челюсти нижняя челюсть содержит большое количество костного мозга, сосредоточенного в теле челюсти. Плотные, сравнительно толстые кортикальные пластинки, затрудняя прорыв гноя на наружную поверхность кости, способствуют диффузному поражению челюсти.

Нижняя челюсть единственная подвижная кость лицевого скелета; к ней прикрепляется большое количество мышц, приводящих ее в движение. Эта особенность определяет сложность строения нижней челюсти и влияние на развитие лицевого скелета и покрывающих скелет мягких тканей.

Развитие нижней челюсти (os mandibula) идет параллельно с развитием верхней челюсти. Развивается нижняя челюсть как парная кость из нескольких точек окостенения, появляющихся в середине второго месяца жизни плода. При окостенении их и срастании с покровной костью формируется суставной отросток нижней челюсти (processus condyloideus), coчленяющийся с височной костью, и расположенный впереди неё венечный отросток (processus coronoideus). С образованием этих отростков в нижней челюсти плода различают горизонтально расположенное тело кости (corpus) и ветви (rami). Верхний край тела кости является альвеолярным отростком, в котором находятся зачатки зубов. К моменту рождения обе половины нижней челюсти соединяются волокнистым хрящом.

В отличие от верхней челюсти нижняя челюсть содержит большое количество костного мозга, сосредоточенного в теле челюсти.

Нижняя челюсть является подвижной костью лицевого скелета, состоящей из тела, ветви, угла. Тело переходит в альвеолярную часть, где располагаются корни зубов. Ветвь имеет два отростка - мыщелковый, заканчивающийся головкой нижней челюсти, и венечный.

Соотношение высоты ветви к протяжённости тела челюсти у взрослых составляет 6,5-7:10. Угол нижней челюсти в норме 120+_5 (Трезубов) 100-110 гр. (Курляндский), у детей 135-140 гр.

На наружной и внутренней поверхности челюсти имеются собственно косая и челюстно-подъязычная линии, которые учитываются при съёмном протезировании. Нижняя челюсть участвует во множестве функций: жевания, звукообразования, речи, глотания и др. Из всех этих функций следует выделить движения, связанные с жеванием.

Таким образом, нижняя челюсть человека может совершать движения в нескольких направлениях: вертикальном (вверх-вниз), что соответствует открыванию и закрыванию рта; сагиттальном (вперед-назад); трансверзальном (вправо-влево); диагональном или косом (вправо-вперед; влево-вперед). Рост челюсти происходит на протяжении 15-16 лет; в течение этого времени идет и созревание зубных фолликулов постоянных зубов. Сращение половин нижней челюсти начинается в возрасте 6 месяцев и заканчивается к концу первого года. Тело нижней челюсти новорожденного 
развито слабо. Венечные и суставные отростки вместе с полулунной вырезкой после рождения только намечены. Суставные отростки едва поднимаются над уровнем альвеолярного отростка. Угол нижней челюсти равен в среднем $150-160^{\circ}$.

При недоразвитии челюсти и некоторых видах прикуса угол челюсти остается тупым. При полной потере зубов угол челюсти также становится тупым. Это является следствием изменения условий работы беззубой челюсти, при которых нижняя челюсть получает возможность перемещаться больше кверху, что ведет к функциональной перестройке угла челюсти.

Нижняя челюсть связана с основанием черепа суставом, который имеет все признаки истинного сустава: покрытые хрящом суставные поверхности, синовиальную оболочку и суставную полость.

Зубная система в процессе онтогенеза приобретает определенную функциональную ориентацию, различную для каждого индивидуума. Определенную функциональную ориентацию имеют и альвеолярные отростки, поэтому альвеолярный отросток на верхней и нижней челюстях в различных отделах обладает различным строением. Это обусловлено функциональными особенностями различных групп зубов. Компактная вестибулярная пластинка альвеолярного отростка в области фронтальных зубов верхней челюсти тонкая. В области премоляров и моляров компактная щечная пластинка более толстая.

На нижней челюсти в области фронтальных зубов язычная стенка альвеолярного отростка значительно толще губной и образует изгиб, обеспечивающий большую сопротивляемость этой части жевательному давлению, направленному спереди назад. Структура кости в области премоляров характеризуется тем, что стенки альвеолярного отростка более толстые, причем язычная стенка также несколько толще вестибулярной. Это результат влияния наибольшей нагрузки на язычную стенку альвеолы в связи с наклонным положением (по направлению к языку) премоляров, жевательная нагрузка в язычную сторону больше, чем нагрузка в щечную сторону (А.Я. Катц). Структура кости в области моляров отличается тем, что внутренняя и наружная косые линии (linea obliqua interna et externa) значительно упрочняют этот отдел альвеолярного отростка.

Альвеолярные отростки играют главную роль в фиксации зубов. На них в первую очередь падает жевательное давление, и в них раньше всего происходит перестройка при ортодонтическом и ортопедическом лечении. 


\section{3. Зубные ряды}

Составной частью жевательно-речевого аппарата являются зубные органыl, в количестве 28 - 32 зубных органа.

Каждый зубной орган состоит из зуба; луночки и прилегающей к ней части челюсти, покрытой слизистой оболочкой десны; связочного комплекса (периодонта), удерживающего зуб в луночке; сосудов и нервов.

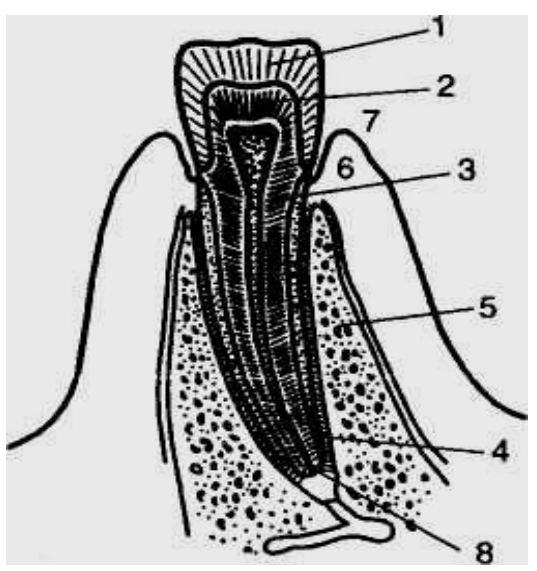

Puc. 3. Схема зубного органа (по И.С. Кудрину):

1 - эмаль; 2 - дентин; 3 - цемент; 4 - периодонт; 5 - альвеолярная часть; 6 - слизистая оболочка десны; 7 - десневая бороздка; 8 - отверстие верхушки корня.

В сформированной зубочелюстной системе определенную приспособленность к нагрузке имеют и зубные ряды. Этому особенно способствует жевательная нагрузка, которая падает на них в вертикальном и горизонтальном направлениях.

Форма зубных рядов у взрослого меняется по сравнению с формой зубных рядов прикуса молочных зубов у детей. Это происходит за счет числа прорезываемых жевательных зубов. Зубной ряд верхней челюсти у взрослого имеет форму эллипсоидную, нижней челюсти - параболоидную (рис. 4).

Зубы прилежат один к другому, образуя выпуклыми поверхностями коронок контактные пункты. Контактные пункты расположены близко к жевательной или режущей поверхности зубов. С возрастом в силу наличия физиологической подвижности у каждого зуба и трения зуба о зуб в точках их соприкосновения контактные пункты превращаются в выраженные контактные площадки. При физиологическом стирании зубов в местах соприкосновения с воз- 
растом зубной ряд укорачивается, причем, по мнению некоторых авторов, укорочение зубного ряда может доходить до 1 см. Контактные пункты укрепляют зубной ряд при нагрузке на отдельные зубы и предохраняют десневой край с апроксимальных сторон зубов от травмы его пищей.

Зубы нижней челюсти наклонены коронками внутрь, а корнями кнаружи. Выпуклость зубной дуги, форма и положение зубов нижней челюсти создают, таким образом для нижнего зубного ряда устойчивость, подобную крепости свода арки, построенной из кирпичей трапециевидной формы. Коронки нижних моляров, кроме того, наклонены вперед, а корни - назад. Это обстоятельство мешает сдвигу зубного ряда назад.

Менее благоприятен для устойчивости зубов верхней челюсти наклон зубов. Зубы верхней челюсти наклонены коронками наружу, а корнями внутрь. Горизонтально действующие силы, возникающие при жевании, способны лишь усилить наклон зуба, который по мере его отклонения наружу все больше лишается поддержки соседнего зуба. Эта особенность расположения зубов компенсируется большим количеством корней у верхних жевательных зубов.

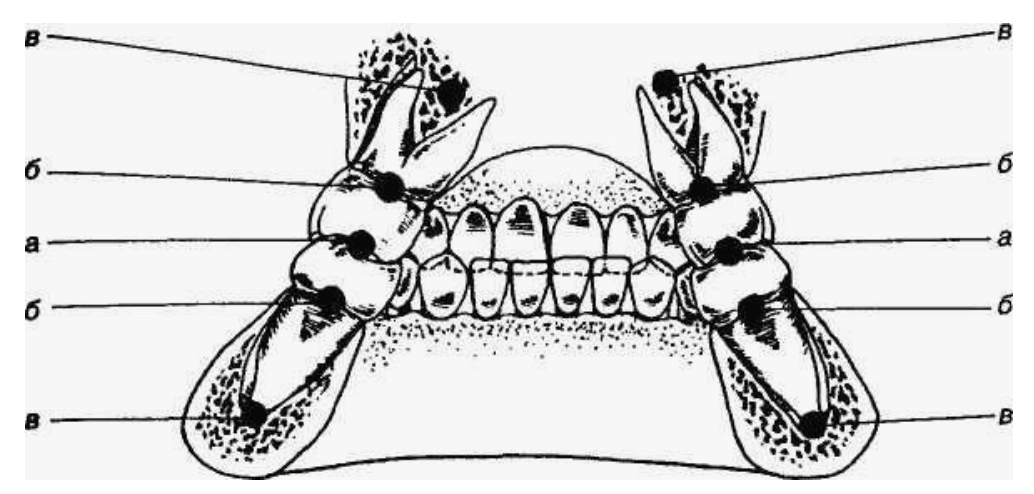

Рис. 5. Соотношение зубных (а), альвеолярных (б) и базальных (апикальных) (в) дуг.

По направлению от мест соприкосновения зубов к десневому краю между зубами образуются межзубные промежутки в виде треугольников, вершина которых обращена к месту соприкосновения зубов, основание - к десневому краю (к шейке зуба).

Межзубные промежутки в практике используют для проведения через них различных лигатур с целью прикрепления к зубам лечебных аппаратов.

Зубной ряд верхней челюсти наклонен несколько вперед и наружу. Режущие края и жевательные поверхности премоляров образуют окклюзионную поверхность. В области жевательных зубов окклюзионная поверхность имеет типичное искривление книзу, что именуют окклюзионной кривой, которая определяется к 11-13 годам. Окклюзионная кривая образуется в силу разности расположения моляров по сравнению с 
другими зубами. Это особенно выражено у вторых и третьих моляров (рис. 6). Так называемая саггитальная окклюзионная кривая - кривая Шпее.

Окклзозионная кривая начинается от медиаль-

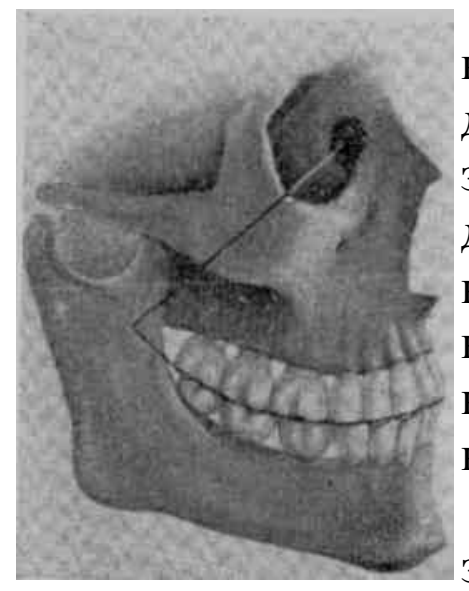
ной поверхности первого моляра и оканчивается у дистального бугра третьего моляра. Устойчивость зубному ряду верхней челюсти и каждому зубу в отдельности придают большие корни зубов. Зубной ряд нижней челюсти характеризуется тем, что резцы и клыки располагаются перпендикулярно по отношению к альвеолярному отростку, жевательные зубы несколько наклонены в сторону языка.

В зубном ряду человека имеются однокорневые зубы - резцы, клыки и премоляры (кроме первого верхнего), двухкорневые - нижние моляры и первые верхние премоляры и трёхкорневые зубы - верхние моляры. Анатомически в каждом зубе различают коронку, шейку и корень. Наружный слой коронки представлен эмалью - самой твёрдой тканью человеческого организма. Шейка зуба находится под десневым краем. На уровне шейки зуба закачивается эмалевое покрытие коронки зуба. Основное назначение корня заключается в фиксации зуба в лунке челюсти при помощи мощного связочного аппарата. В коронковой части зуба находится зубная полость, которая переходит в канал корня зуба, заканчивающийся корневым отверстием. В полости зуба находится рыхлая ткань - пульпа зуба.

Анатомо - топографически выделяют коронковую и корневую пульпу зуба. В коронке зуба ткань пульпы заполняет полость зуба и образует своеобразные выросты - рога пульпы, которые соответствуют бугоркам жевательной поверхности премоляров и моляров и режущего края резцов и клыков. В однокорневых зубах коронковая пульпа незаметно переходит в корневую пульпу, а в многокорневых - между коронковой и корневой пульпой имеется выраженная граница. У лиц среднего возраста свод коронковой полости расположен приблизительно на уровне шейки зуба. Через верхушечное отверстие корня зуба из периодонта в пульпу проникает сосудисто-нервный пучок, соединительная ткань пульпы находится в непосредственной близости от аналогичной ткани периодонта.

Кровоснабжение и иннервация пульпы осуществляется благодаря зубным артериальным, венозным и нервным веточкам (aa. dentales, nn. dentales) соответствующих артерий, вен и нервов челюстей. Проникая в полость зуба через апикальное отверстие канала корня зуба, они распадаются на более мелкие ветви, пронизывая пульпу и образуя густые сплетения. Пульпа способствует регенеративным процессам, которые проявляются в образовании вторичного или третичного дентина при кариозном процессе, является биологическим барьером, препятствующим проникновению микробов из кариозной полости через канал корня зуба в периодонт.

Знания анатомо-топографических особенностей строения пульпы необходимы в практической деятельности стоматолога при диагностике 
осложнённых форм кариеса и выборе метода лечения, алгоритме их выполнения.

Зуб фиксируется в лунке зуба при помощи связочного аппарата, состоящего из прочных соединительнотканых волокон, идущих от шейки и корня зуба к кортикальной костной пластинке, выстилающей лунку челюсти. В области шейки зуба эти пучки имеют почти горизонтальное направление и совместно с десной и надкостницей челюсти образуют так называемую круговую связку зуба, которая отделяет пространство между корнем и стенкой альвеолы от внешней среды. Узкая щель между корнем зуба и стенкой альвеолы в норме заполнена связочным аппаратом зуба, кровеносными, лимфатическими сосудами и нервами и называется периодонтом.

Связочный аппарат зуба выполняет не только фиксирующую, но и амортизирующую роль, что обеспечивается наличием между пучками соединительнотканых волокон рыхлой клетчатки и межтканевой жидкости.

При акте жевания на каждый моляр падает нагрузка от 50 до 80 кг. Несмотря на значительную нагрузку при акте жевания, связочный аппарат удерживает зуб в подвешенном положении, предупреждая тем самым травму дна лунки смещающимся по продольной оси корнем зуба. Через многочисленные отверстия в стенке лунки между сосудами периодонта и сосудами челюсти проходят анастомозы, а сам периодонт сообщается с костномозговым веществом челюсти. Это способствует свободному проникновению инфекции при воспалительном процессе из периодонта в костный мозг челюсти, что может явиться причиной одонтогенного остеомиелита.

\section{4. Виды физиологического и аномального прикуса}

Основные виды физиологического прикуса: ортогнатический, физиологическая прогения, бипрогнатический и прямой.

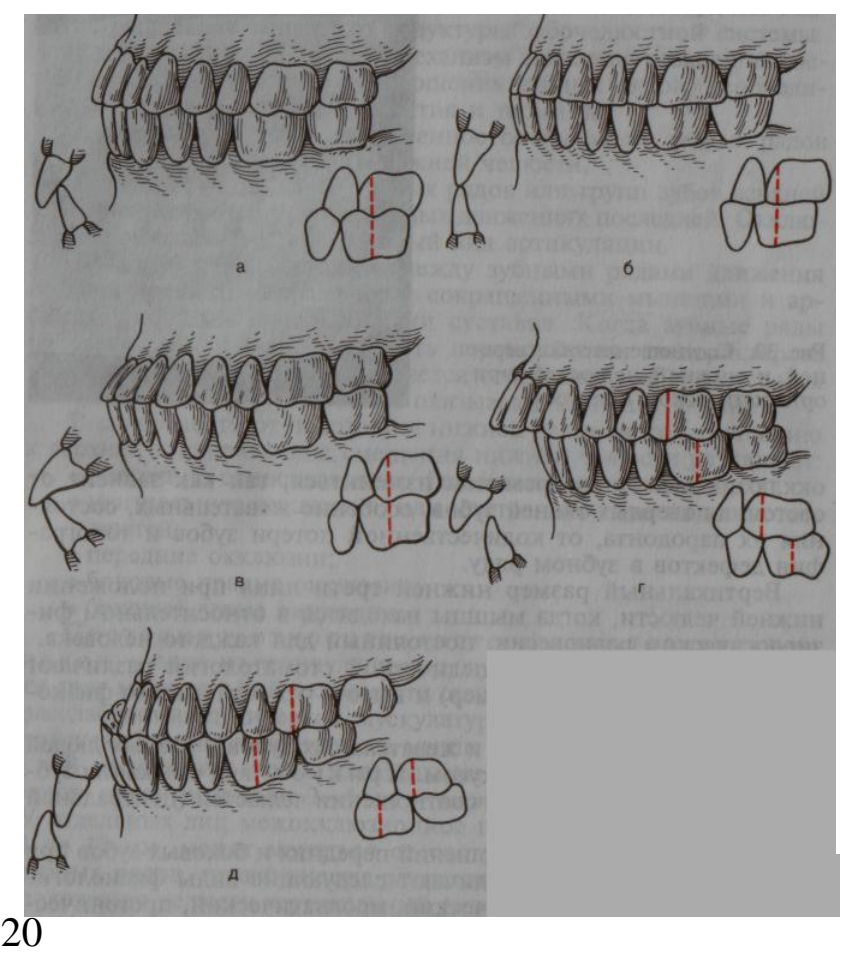

Рис. 7. Физиологические виды прикуса: a - ортогнатический; б - прямой; в - бипрогнатия; г - прогнатия, д - прогения.

Сбоку слева - соотношение резцов, справа - соотношение первых постоян ных моляров. 
Ортогнатический прикус, сформированный из постоянных зубов, характеризуется основными признаками: на челюсти все зубы; каждый зуб верхней и нижней челюсти смыкается с одноименным зубомантагонистом, который именуют главным и побочным (исключение составляют центральные резцы нижней челюсти и третьи моляры верхней челюсти, которые смыкаются только с одноименными антагонистами). Средние линии, проходящие между центральными резцами верхней и нижней челюсти, лежат в одной сагиттальной плоскости. Верхние передние зубы перекрывают нижние приблизительно на $1-3$ коронки; нижние передние зубы своими режущими поверхностями контактируют с зубным бугорком верхних зубов. Щечные бугорки верхних премоляров и моляров расположены кнаружи от одноименных бугорков нижних премоляров и моляров (благодаря этому небные бугорки верхних зубов попадают в продольные бороздки нижних, а нижние щечные - в продольные бороздки верхних зубов). Передний щечный бугорок первого верхнего моляра располагается на щечной стороне нижнего первого моляра в поперечной борозде между щечными бугорками.

При отсутствии основных характеристик, присущих физиологическому прикусу, различают восемь основных типов аномалийного прикуса (классификация зубочелюстных аномалий ВОЗ): дистальная окклюзия, мезиальная окклюзия, чрезмерное перекрытие - горизонтальный перекрывающий прикус, чрезмерное перекрытие - вертикальный перекрывающий прикус, открытый прикус, перекрестный прикус боковых зубов, лингвоокклюзия боковых зубов нижней челюсти, смещение от средней линии. Например: «Глубокая резцовая окклюзия» ( рис.8)

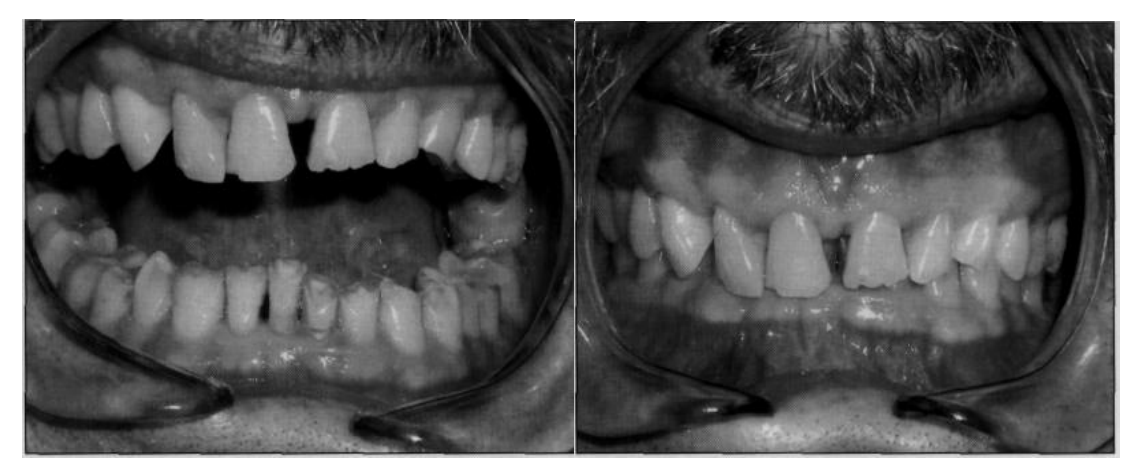

Рис. 8. Частичное отсутствие зубов на верхней челюсти. Генерализованное повышенное стирание твёрдых тканей зубов (смешанная форма). Деформация зубных рядов. Локализованный пародонтит в области зубов 4.2, 4.1, 3.1 лёгкой степени. Дистальное смещение нижней челюсти. Снижение высоты нижнего отдела лица на 4 мм. Глубокая резцовая окклюзия. Диастема на верхней челюсти. 
Сложное переплетение внутренних и внешних факторов, определяющих развитие жевательного аппарата, приводит к формированию переходных вариантов, которые невозможно отнести к норме и которые необходимо определять как патологические. Например, верхние резцы располагаются в челюсти по несколько изогнутой дуге, иногда почти по прямой линии.

Вследствие часто имеющего место несоответствия размеров верхних резцов размерам альвеолярного отростка они нередко располагаются скученно.

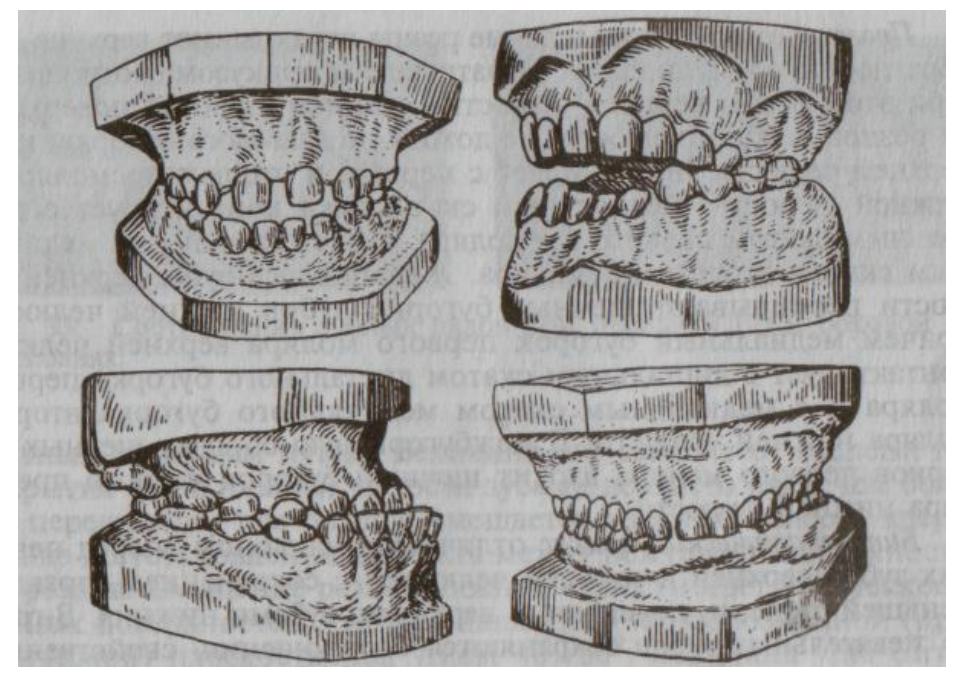

Рис. 9. Аномальные виды прикуса.

Оценку прикуса и сохранность окклюзионных соотношений проводят при сомкнутых зубных рядах и при положении нижней челюсти в физиологическом покое.

Чаще всего центральные резцы смещаются в вестибулярном направлении, а латеральные - в небном, но может быть и наоборот. Нередко сокращение длины зубного ряда в области резцов образуется за счет поворота последних вокруг оси. Уменьшение переднего отдела верхнего зубного ряда довольно часто происходит за счет редукции латеральных резцов (от уменьшения размеров и изменения форм коронки до полного отсутствия зачатков). В ряду верхних резцов наблюдаются явления противоположного порядка, а именно: наличие дополнительных (сверхкомплектных) зубов. Чаще всего сверхкомплектный зуб располагается между центральными резцами. Наибольшее значение имеет диастема между центральными резцами, которая связанна с чрезмерным развитием соединительной ткани в этой области.

Верхние клыки, как правило, не подвержены значительной редукции. Это устойчивые, хорошо развитые зубы. Случаи сверхкомплектных клыков отмечаются, но значительно реже резцов. Клык обычно выступает несколько в вестибулярном направлении. Довольно часто верхний клык аномалийно прорезывается или ретенируется. 
Верхние премоляры располагаются на закругленном отрезке дуги альвеолярного отростка верхней челюсти. Скученность премоляров может проявляться в сдвиге одного из них в небном направлении. Промежутков между премолярами, как правило, не бывает. В области верхних премоляров наблюдаются как процессы дифференциации (массивность и угловатость вестибулярных бугорков, выраженность гребней и борозд, образование дополнительных бугорков), так и процессы редукции (сглаженность рельефа коронки, уменьшение ее размера, уменьшение межбугорковой бороздки).

При нормальной эллипсовидной форме альвеолярного отростка верхние моляры располагаются по дуге. При параболоидной форме альвеолярного отростка они располагаются почти прямо. Верхние моляры в альвеолярном отростке располагаются веерообразно, т.к. коронки наклонены в вестибулярную сторону. Наиболее стабильным (ключевым) зубом является первый моляр, наиболее вариабельным - третий моляр. Третий моляр часто бывает ретенирован или аномалийно расположен. Это связано с недостатком места на альвеолярном отростке. Реже в ряду верхних моляров наблюдается гиперодонтия (четвертый моляр).

Нижние резцы, как правило, располагаются на альвеолярном отростке выпуклой кнаружи дугой. Они часто имеют скученное положение с различным поворотом вокруг оси. Редукция нижних резцов выражена незначительно, следовательно, гиподентия встречается крайне редко. Также редко встречается сверхкомплектный нижний резец между центральными резцами. Между резцами встречается диастема, хотя значительно реже, чем на верхней челюсти.

Нижние клыки, как и верхние, несколько выступают в вестибулярном направлении. Клык - зуб мало подверженный редукции. Нижний клык очень часто расположен аномалийно (чаще смещен в вестибулярном направлении). Между нижним клыком и первым премоляром часто наблюдается трема.

Форма премоляров широко варьирует - от клыкообразного до моляроподобного. Нижние премоляры нередко располагаются скученно.

Нижние моляры у современного человека располагаются приблизительно по прямой линии, хотя третий моляр может занимать различное положение вплоть до расположения его в ветви челюсти. Вертикальные оси нижних моляров наклонены в язычную сторону. Наиболее стабильным в этом ряду является первый моляр. Третий нижний моляр - зуб наиболее вариабельный, его коронка может иметь от 3 до 6 бугорков.

Этот зуб нередко бывает ретенирован. Промежутки (тремы) между нижними молярами наблюдаются весьма редко.

Таким образом, зуб представляет собой орган с довольно сложным строением, знание которого необходимо для правильного представления о физиологических и патологических процессах, происходящих в нём. 


\section{5. Мышцы челюстно-лицевой области}

Рост мышц челюстно-лицевой области и их развитие происходит одновременно с развитием лицевого скелета и в процессе функционирования. Развиваясь, мышцы влияют на лицевой скелет, на соединительную ткань, на кожу, определяют внешний вид лица. Взаимно влияя друг на друга (скелет и мускулатура), органы челюстно-лицевой области приобретают определенную функциональную направленность.

Нарушения в развитии скелета или мускулатуры ведут к аномалийному формированию органов, которые обладают сниженной работоспособностью и малой резистентностью к отрицательно воздействующим внутренним и внешним факторам.

Мышцы челюстно-лицевой области развиваются из мезенхимы, окружающей первую челюстную дугу. Все мышцы челюстно-лицевой области состоят из нескольких самостоятельных групп и объединяются в одно целое лишь с анатомической точки зрения и в соответствии с их конечной комплексной функцией.

К самостоятельным мышечным группам относятся: 1) мимическая мускулатура, 2) жевательная мускулатура, 3) мышцы языка, 4) мышцы мягкого неба и 5) мышцы глотки.

Деление это условно, как условно любое выделение частей организованного целого. Все эти мышцы принимают участие в разнообразных сочетанных функциях органов этой области, и каждая группа мышц имеет свою главную функциональную ориентацию. Так, например, мимические мышцы преимущественно участвуют в мимике, дыхании и речи, меньше - в жевании. Жевательные - в жевании и речи, меньше - в дыхании.

Работа мышц происходит под влиянием центральной нервной системы на основе импульсов как исходящих из внешней среды, так и возникающих в самом организме. У человека в связи с высокой дифференциацией головного мозга эти качества достигают наибольшего развития.

Подробное изучение мышц челюстно-лицевой области в норме и при патологических состояниях дает возможность рационально построить план лечения, включая миогимнастику.

Схема действия жевательных мышц

\begin{tabular}{|l|l|l|l|}
\hline Наименование мышцы & $\begin{array}{l}\text { Собственная } \\
\text { функция мыш- } \\
\text { цы }\end{array}$ & $\begin{array}{l}\text { Одновременное } \\
\text { сокращение же- } \\
\text { вательных мышц } \\
\text { на одной стороне }\end{array}$ & $\begin{array}{l}\text { Одновременное } \\
\text { двустороннее со- } \\
\text { кращение жева- } \\
\text { тельных мышц }\end{array}$ \\
\hline $\begin{array}{l}\text { Собственно жевательная } \\
\text { (m. masseter) }\end{array}$ & $\begin{array}{l}\text { Поднимает } \\
\text { нижнюю че- } \\
\text { люсть, продви- } \\
\text { гает }\end{array}$ & \\
\hline
\end{tabular}




\begin{tabular}{|c|c|c|c|}
\hline $\begin{array}{l}\text { Внутренняя крыловидная } \\
\text { (m. pterygoideus internus) }\end{array}$ & $\begin{array}{l}\text { Поднимает ниж- } \\
\text { нюю челюсть, } \\
\text { продвигает впе- } \\
\text { ред, отводит } \\
\text { в свою сторону }\end{array}$ & $\begin{array}{l}\text { Поднимает ниж- } \\
\text { нюю челюсть и } \\
\text { отводит её в про- } \\
\text { тивоположную } \\
\text { сторону }\end{array}$ & $\begin{array}{l}\text { Поднимает } \\
\text { нижнюю че- } \\
\text { люсть или под- } \\
\text { нимает ниж- } \\
\text { нюю челюсть и } \\
\text { отводит кзади }\end{array}$ \\
\hline Височная (m. temporalis) & $\begin{array}{l}\text { Поднимает ниж- } \\
\text { нюю челюсть, от- } \\
\text { тягивает назад, } \\
\text { отводит в проти- } \\
\text { воположную сто- } \\
\text { рону }\end{array}$ & & \\
\hline $\begin{array}{l}\text { Подбородочно-язычная } \\
\text { (m. genio-glosus) }\end{array}$ & $\begin{array}{lr}\text { Отводит } & \text { нижнюю } \\
\text { челюсть } & \text { кзади, } \\
\text { поднимает } \\
\text { кверху }\end{array}$ & $\begin{array}{l}\text { Отводит нижнюю } \\
\text { челюсть в проти- } \\
\text { воположную сто- } \\
\text { рону }\end{array}$ & $\begin{array}{l}\text { Поднимает } \\
\text { нижнюю че- } \\
\text { люсть и отво- } \\
\text { дит кзади }\end{array}$ \\
\hline $\begin{array}{l}\text { Наружная крыловидная } \\
\text { (m. pterygoideus externus) }\end{array}$ & $\begin{array}{l}\text { Продвигает ниж- } \\
\text { нюю челюсть } \\
\text { вперёд, отводит } \\
\text { вниз в противопо- } \\
\text { ложную сторону }\end{array}$ & $\begin{array}{l}\text { Продвигает ниж- } \\
\text { нюю челюсть впе- } \\
\text { ред, опускает её и } \\
\text { отводит в проти- } \\
\text { воположную сто- } \\
\text { рону }\end{array}$ & $\begin{array}{l}\text { Продвигает } \\
\text { нижнюю че- } \\
\text { люсть вперед и } \\
\text { опускает её }\end{array}$ \\
\hline $\begin{array}{l}\text { Двубрюшная (m. digas- } \\
\text { tricus) }\end{array}$ & $\begin{array}{l}\text { Опускает ниж- } \\
\text { нюю челюсть, от- } \\
\text { тягивает кзади, и } \\
\text { отводит в проти- } \\
\text { воположную сто- } \\
\text { рону }\end{array}$ & $\begin{array}{l}\text { Опускает ниж- } \\
\text { нюю челюсть и } \\
\text { отводит в проти- } \\
\text { воположную сто- } \\
\text { рону }\end{array}$ & $\begin{array}{l}\text { Опускает ниж- } \\
\text { нюю челюсть и } \\
\text { оттягивает кза- } \\
\text { ди }\end{array}$ \\
\hline $\begin{array}{l}\text { Подбородочно- } \\
\text { подъязычная (m. geniohy- } \\
\text { oideus) }\end{array}$ & $\begin{array}{l}\text { Опускает нижнюю } \\
\text { челюсть и отводит } \\
\text { кзади }\end{array}$ & $\begin{array}{l}\text { Отводит нижнюю } \\
\text { челюсть в проти- } \\
\text { воположную сто- } \\
\text { рону }\end{array}$ & \\
\hline
\end{tabular}

\section{Мимическая мускулатура}

Индивидуальные особенности лица человека, психологические реакции, связанные с изменением выражения лица (радость, грусть, испуг и др.) обеспечивает большая группа мимических мышц. Отсутствие адекватной реакции лица на тот или иной факт говорят о маскообразном выражении лица. Для человека характерна игра мимической мускулатуры, отражающая психологическую настроенность субъекта в данный момент. 
Поверхностная мышца шеи, мышцы лица и головы являются собирательной мимической мускулатурой, обусловливают функцию ротовой щели, органов полости рта, глотки и глаз и обладают самостоятельной мимической функцией. Работа мышц лица определяется как содружественной их деятельностью, так и наличием антагонизма между отдельными мышцами и между группами мышц. Кроме содружественной работы мышц обеих сторон имеет место самостоятельное функционирование мимических мышц левой и правой стороны.

Опорой для мышц лица с одной стороны служит кость (место начала- лицевой скелет), с другой - лабильные мягкие ткани (место прикрепления), главным образом mm. orbicularis oris et orbicularis oculi, которые, образуя опору для многих мышц, одновременно являются их основными антагонистами.

\section{Язык и его мышцы}

Функции органов полости рта - жевания и речи - принадлежит языку. При поражении языка (парез, паралич, ампутация) акт обработки пищи нарушается. Аномалии мышц языка (увеличение размеров) нарушают развитие зубочелюстной системы. Язык состоит из мышц, расположенных в поперечном, вертикальном и продольном направлениях. Все мышцы переплетаются между собой.

Различают мышцы, начинающиеся на костях, и мышцы, начинающиеся в мягких тканях, - собственные мышцы языка. Мышцы, начинающиеся на костях, обеспечивают перемещение языка во всех направлениях, при этом они перемещают и натягивают ткани дна полости рта, изменяя их форму. Изменение положения языка осуществляется подбородочноязычными мышцами (mm. genioglossus), подъязычно-язычными мышцами (mm. hyoglossus) и шилоязычными мышцами (mm. styloglossus).

\section{Участие мышщ языка в разных его перемешениях}

\begin{tabular}{|c|c|c|}
\hline $\begin{array}{l}\text { Направление } \\
\text { перемещения } \\
\text { мышц языка }\end{array}$ & $\begin{array}{l}\text { Основные мышцы, пере- } \\
\text { мещающие язык }\end{array}$ & $\begin{array}{l}\text { Мышцы или пучки их, принима- } \\
\text { ющие участие в перемещении } \\
\text { языка }\end{array}$ \\
\hline Вперед & $\begin{array}{l}\text { Подбородочно-язычные } \\
\text { мышцы }\end{array}$ & 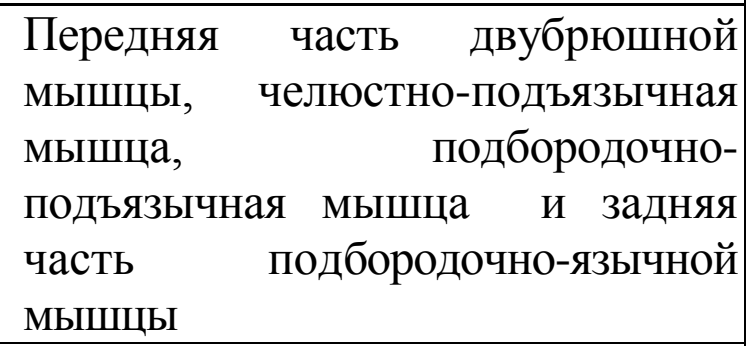 \\
\hline Назад & $\begin{array}{l}\text { Шилоязычные мышцы и } \\
\text { задние отделы подъя- } \\
\text { зычно-язычных мышц }\end{array}$ & $\begin{array}{l}\text { Мышцы, фиксирующие подъ- } \\
\text { язычную кость }\end{array}$ \\
\hline
\end{tabular}




\begin{tabular}{|l|l|l|}
\hline Книзу & $\begin{array}{l}\text { Подъязычн-язычные } \\
\text { мышцы и средняя часть } \\
\text { подбородочно-язычных } \\
\text { мышц }\end{array}$ & $\begin{array}{l}\text { Мышцы, фиксирующие подъ- } \\
\text { язычую кость }\end{array}$ \\
\hline Кверху & $\begin{array}{l}\text { Шилоязычные, двуб- } \\
\text { рюшные и шило- } \\
\text { подъязычные мышцы }\end{array}$ & $\begin{array}{l}\text { Пелюстно-подъязычные, } \\
\text { подбородочно-подъязычные, } \\
\text { отделы) и мышцы мягкого неба }\end{array}$ \\
\hline В сторону & $\begin{array}{l}\text { Шилоязычная и подъ- } \\
\text { язычно-язычная мышцы } \\
\text { (с одной стороны) }\end{array}$ & $\begin{array}{l}\text { Мышцы, фиксирующие } \\
\text { подъязычную кость }\end{array}$ \\
\hline
\end{tabular}

Все движения языка могут происходить либо при расслабленной мускулатуре языка, либо при условии сокращений собственных мышц языка. Часто необходима при этом плотная фиксация подъязычной кости.

Собственные мышцы языка, сокращаясь, делают язык плоским или утолщают его, или же придают ему желобообразную форму.

Слизистая оболочка языка в различных местах имеет различное строение и снабжена многочисленными сосочками: 1) нитевидные (papillae filiformes), 2) грибовидные (papillae fungiformes); 3) желобоватые сосочки (papillae vallatae); 4) листовидные (papillae foliatae)

\section{6. Анатомо-физиологические особенности височно-нижнечелюстного сустава}

Строение височно-нижнечелюстного сустава (ВНЧС) характеризуется некоторыми анатомическими и функциональными особенностями по сравнению с другими суставами человека.

ВНЧС сформировался в филогенезе в зависимости от характера прикуса и движения нижней челюсти и от эволюции лицевого и мозгового отделов черепа. Он сложен не только по анатомическому строению, но и по функции, и представляется как замкнутая кинематическая система, движение в одном суставе вызывает движение и в другом. ВНЧС относится к двухосным суставам, движения в нем происходят по двум осям - горизонтальной и вертикальной. Сустав обладает тремя степенями свобод движения - в вертикальном, сагиттальном и поперечном направлениях. Большую роль в комбинации суставных движений играет нейрогенный фактор. Височно-нижнечелюстной сустав состоит из двух сочленений, связанных нижней челюстью. Движения только в одном сочленении являются невозможными (оба сочленения обязательно должны работать одновременно).

Сустав инконгруэнтный. ВНЧС - это специфический сустав, присущий только человеку. По мнению В.А. Хватовой, инконгруэнтность суставных поверхностей создает неустойчивость внутрисуставных взаимоот- 
ношений, а также полную зависимость этих взаимоотношений от смыкания зубных рядов и состояния жевательных мышц.

Элементами нижнечелюстного сустава являются: нижнечелюстная ямка, суставной бугорок, головка нижней челюсти и мыщелковый отросток, суставной диск, суставная капсула, нижнечелюстные суставные связки. Височно-нижнечелюстной сустав - сочленение, образованное височной и нижнечелюстной костью. Суставная ямка и суставной бугорок являются частью височной кости; суставная (нижнечелюстная) головка и суставной (мыщелковый) отросток относятся к нижнечелюстной кости.

У новорождённого элементы височно-нижнечелюстного сустава слабо развиты и не имеют чёткой функциональной ориентированности, после 6-7-летнего возраста происходит формирование элементов височнонижнечелюстного сустава.

Височно-нижнечелюстной сустав состоит из суставной ямки, расположенной на височных костях, и суставной головки нижней челюсти.

Каждое сочленение имеет хрящ-диск, суставную сумку, связочный аппарат. Форма элементов, составляющих височно-нижнечелюстное сочленение строго индивидуальна, и зависит от движений, происходящих в суставе. Движения в суставе обусловливаются работой жевательных мышц. Изменения работы мышц всегда ведут к изменению работы суставов, в результате чего появляются и изменения формы элементов. Височнонижнечелюстное сочленение индивидуально и зависит от движений, происходящих в суставе. Типичную форму приобретают элементы височнонижнечелюстного сустава при аномалиях развития зубочелюстной системы, что указывает на их зависимость. Изменения в форме височнонижнечелюстного сустава наблюдаются и при потере зубов, так как при этом изменяется работа жевательной мускулатуры. Перестройка в височнонижнечелюстном суставе происходит и под действием ортопедического лечения височно-нижнечелюстного сустава.

Функция височно-нижнечелюстного сустава. Особенностью движений суставной головки является комбинация поступательных и вращательных движений в суставе. Любое движение в суставе начинается с поступательного движения-скольжения суставной головки по заднему скату суставного бугорка, затем присоединяется вращательное движение вокруг горизонтальной оси головки. Эта характерная функциональная особенность отличает височно-нижнечелюстной сустав от других суставов скелета человека. Она обусловлена наличием в полости сустава суставного диска, который делит полость сустава на две камеры. В верхней камере происходят поступательные движения, и головка смещается вниз по заднему скату суставного бугорка. В нижней камере одновременно происходят вращательные движения вокруг горизонтальной оси, т.е. два отдела сустава, изолированные друг от друга диском, едины при выполнении функции, так как разнонаправленные движения в суставе происходят одновременно.

Другой функциональной особенностью височно-нижнечелюстного сустава является синхронность движений в двух суставах, так как оба су- 
става (правый и левый) связаны между собой непарной нижнечелюстной костью. Эту особенность необходимо учитывать при диагностике заболеваний височно-нижнечелюстного сустава.

a)

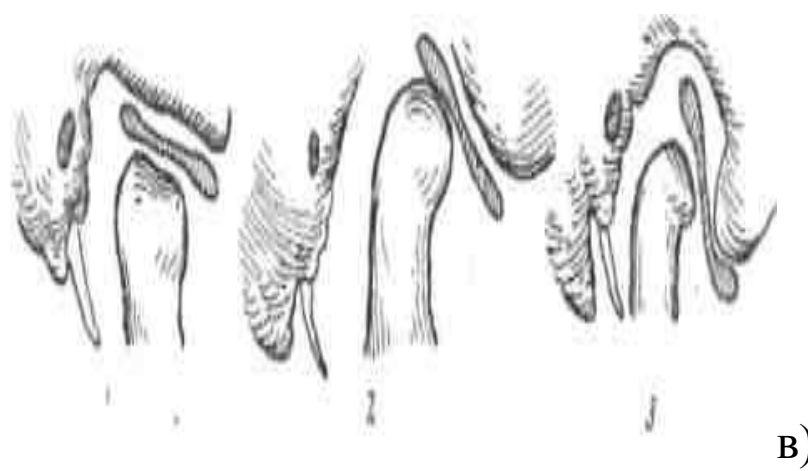

Puc. 10. Три формы суставного бугорка: а) плоская; б) средняя;

в) крутая.

Суставные головки при жевании совершают движения следующих плоскостях:

- вертикальной (открывание и закрывание рта);

- саггитальной (поступательное движение кпереди и кзади);

- трансверзальной (смещение вправо и влево).

Стабильность положения нижней челюсти обеспечивают окклюзионные контакты жевательных зубов, которые препятствуют смещению нижней челюсти, осуществляя «окклюзионную защиту» ВНЧС.

Предрасполагающими к развитию патологии являются четыре типа ВНЧС:

1 - эталон нормы - высокая суставная ямка, хорошо развитый мыщелок, умеренно развитый мениск, мыщелок располагается в центре суставной ямки,

2 - глубокая суставная головка, небольшой по размеру мыщелок и мощный мениск,

3 - глубокая, узкая суставная ямка, хорошо развитый мыщелок и уплощённый мениск,

4 - широкая уплотнённая суставная ямка при небольшом по размеру мыщелке при хорошо развитом мениске.

\section{7. Антропометрические закономерности}

Индивидуальные особенности строения лица и антропометрические закономерности его строения являются важными для диагностики заболеваний органов полости рта и челюстно-лицевой области. 
Тип лица обусловливается размерами челюстей. Чем больше высота челюстей, тем длиннее лицо. Высота верхней челюсти с зубами колеблется в пределах 20-30 мм. Высота нижней челюсти с зубами равна 32-50 мм.

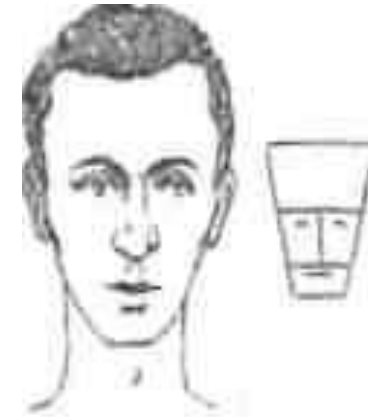

a)

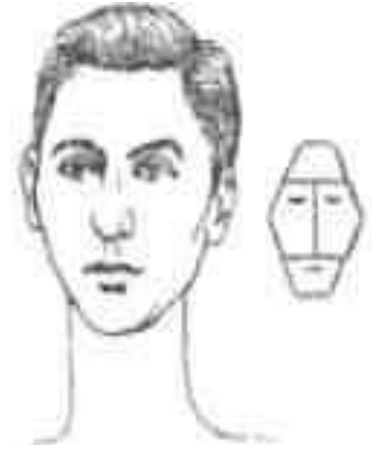

б)

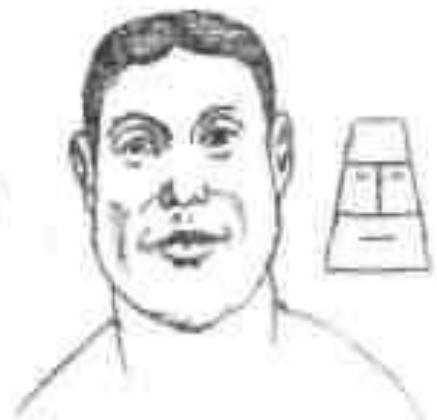

B)

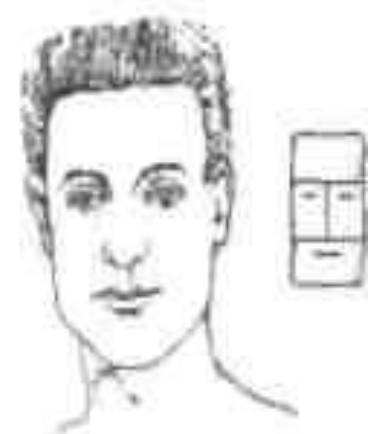

г)

Рис. 11. Типы лица (по Бауэру) а) церебральный; б) респираторный; в) дигестивный; г) мышечный

На тип лица оказывает влияние развитость мозгового черепа, дыхательного аппарата, жевательного аппарата или костно-мышечной системы. Соответственно можно различать четыре типа лица: церебральный, респираторный, дигестивный и мышечный.

Высота лицевого черепа измеряется от точки basion до точки gnathion, ширина (скуловой диаметр) - между наиболее выступающими участками скуловых дуг. Высокий и широкий лобный отдел лица резко преобладает над остальными отделами, вследствие чего лицо приобретает пирамидальную (коническую) форму с основанием, направленным кверху. Мимика при церебральном типе лица концентрируется обычно в лобном отделе, вокруг больших и живых глаз.

Респираторный тип характеризуется преобладающим развитием среднего отдела лица (дыхательный аппарат), лицевая часть головы, шея и туловище приобретают ряд характерных особенностей. Сильно развиты полости носа и его придатки, верхнечелюстные пазухи велики, скулы немного выступают. Лицо имеет ромбовидную форму, нос сильно развит в длину, его спинка нередко выпукла.

Дигестивный тип характеризуется преобладающим развитием нижнего отдела лица (жевательный аппарат). Верхняя и нижняя челюсти чрезмерно развиты. Расстояние между углами нижней челюсти велико. Ветвь нижней челюсти очень широка, массивна, ее венечный отросток короток и широк, жевательные мышцы сильно развиты. Рот окаймлен толстыми губами. Подбородок широк и высок. Вследствие сильного развития нижнего отдела лица при относительной узости лобной части лицо приобретает иногда характерную форму трапеции (обратноконическое лицо). Линия границы волос нередко выпукла кверху. Мимика концентрируется преимущественно в нижнем отделе лица. 
Мышечный тип - верхний и нижний отделы лица приблизительно равны, граница волос обычно прямая, лицо квадратной формы. Исследования показывают, чаще всего один тип сочетается с другим, а различие устанавливается только на основании преобладания тех или иных признаков, определяющих тип лица.

Следует отметить, что лицо человека диспропорционально: отмечается асимметрия в строении левой и правой половины. Это проявляется в том, что левая половина мозгового черепа больше правой половины, а левая половина лица длиннее. Спинка носа не совпадает со средней линией, кончик носа сдвинут на сторону. Расстояние между наружным углом глаза и углом рта не одинаково на обеих половинах лица, правая скуловая кость и нижняя половина верхней челюсти сдвинуты вправо, правая собачья ямка (Fosa canina) более глубокая и узкая. Зубы верхней челюсти и нижняя часть перегородки носа сдвинуты вправо.

\section{8. Высота нижнего отдела лица}

В стоматологии довольно часто применялся термин «высота прикуса». Одни под этим понимают высоту нижней трети лица, другие - расстояние между альвеолярными отростками челюстей, а некоторые отождествляют оба эти расстояния в качестве определяющих одну и ту же величину. Термин «высота прикуса» неверен, так как прикус - это тип соотношения зубных рядов, который, естественно, не может иметь ни высоты, ни ширины. Заменяющим термин «высота прикуса» является термин «высота нижнего отдела лица», что следует из общепризнанных антропометрических положений. В антропологии различают мозговой и лицевой череп. Для характеристики формы, размеров и соотношений различных частей установлены условные определенные точки: края костей, бугры, отверстия, швы - места пересечения линий и плоскостей.

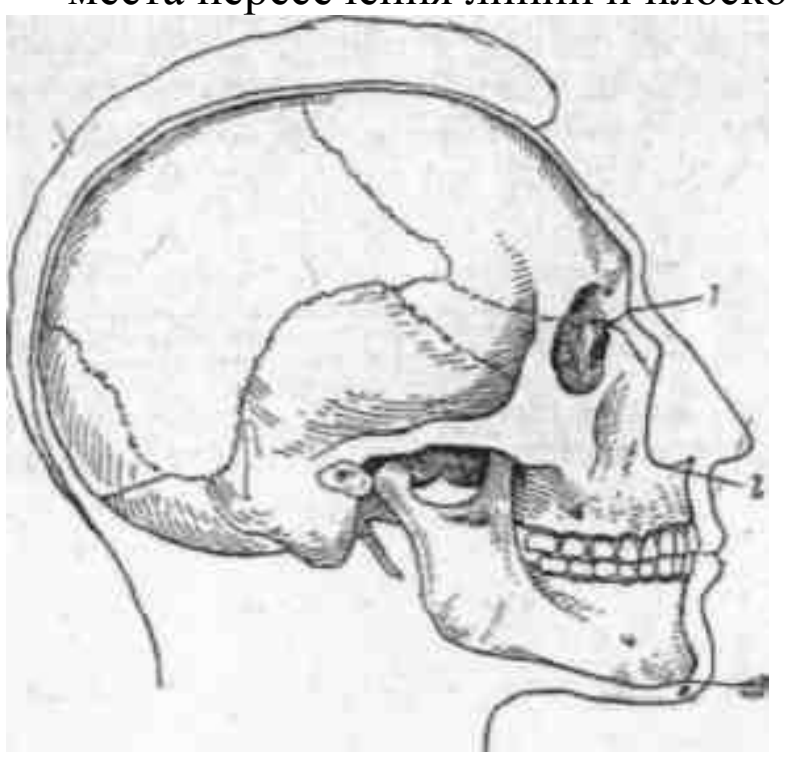

Рис. 12. Антропометрические точки для определения высоты лицевого черепа: 1) nasion; 2) nasospinate; 3) gnathion. 
Антропометрическими точками, определяющими высоту лицевого черепа, являются: точка на середине основания носа - nasion, лежащая в месте пересечения sutura nasofrontalis и sutura internasalis; челюстная точка gnathion, наиболее выступающая книзу точка, расположенная на нижнем крае нижней челюсти по медианной плоскости. Точка nasospinate самая глубокая точка, расположенная ниже нижнего края apertura piriformis, лежащая в медианной плоскости; она залегает у основания spina nasalis anterior и делит лицевой череп на верхний и нижний отделы (рис. 8).

Лицо делят на три части: от границы волосистой части лба до середины линии надбровных дуг - верхняя треть лица, средняя треть лица начинается от середины линии надбровных дуг и кончается краями крыльев носа, от края крыльев носа до нижней части подбородка - нижняя треть лица. Лицо может быть разделено также с помощью четырех горизонталей: первая горизонталь проводится по границе волос на лбу, вторая - по верхнему краю бровей, третья - через носовую точку и четвертая - через подбородочную. 


\section{РАЗДЕЛ ІІ. ДИАГНОСТИЧЕСКИЙ ПОИСК СИНДРОМНО- СХОДНЫХ ЗАБОЛЕВАНИЙ}

Обследования челюстно-лицевой области больного является звеном общего обследования всего организма и изучения условий его существования во внешней среде и не имеет самостоятельного значения. В условиях целостного организма нет изолированных органов и систем.

Исследование челюстно-лицевой области должно входить в план общего обследования больного врачом любой специальности.

Первым этапом обследования больного является сбор анамнеза, включающего жалобы больного, историю заболевания и жизни больного. Круг вопросов, которые задает больному врач, зависит от характера болезни.

Врач-стоматолог при сборе анамнеза должен обратить внимание на сопутствующие заболевания. Иногда при расспросе удается установить, что ухудшение состояния зубочелюстной системы наступило в период обострения заболеваний желудочно-кишечного тракта или после гриппа.

Для облегчения диагностического и лечебного процессов жалобы больного условно можно классифицировать как основные (главные) и второстепенные. Нередко пациенты предъявляют жалобы, которые на их взгляд являются основными (главными), а с точки зрения врача являются второстепенными. Например, пациенты обращают внимание на некрасивое положение переднего зуба, не замечая при этом тяжелой аномалии зубных дуг в виде их сужения. Обычно больные фиксируют внимание врача на местном поражении и реже жалуются на связь местного заболевания с нарушением функции других органов. Например, пациенты предъявляют жалобы на стоматологическую патологию и не связывают ее с появившимися нарушениями деятельности желудочно-кишечного тракта.

Наиболее характерными из них являются жалобы на болевые ощущения, которые могут быть постоянными или временными, острыми или тупыми, локализованными или разлитыми, самопроизвольными или связанными с прикосновением к зубу, участку тканей лица, челюстей и другими раздражениями.

Больные могут жаловаться на затрудненное пережевывание пищи (кариес, заболевания пародонта, травматическая окклюзия, отсутствие нескольких или всех зубов). На боль и кровоточивость в деснах, слизистой оболочке, на обильное слюнотечение или наоборот сухость во рту, патологическую стираемость или подвижность зубов, могут предъявлять жалобы по поводу дефекта или деформации лица, которые вызывают функциональные и эстетические нарушения.

Мышечная дисфункция может вызывать головные боли и боли в области шеи и плечевого пояса, спины, боли в области ВНЧС, нарушение осанки, неприятные ощущения в области глаз, боль за ушами, нарушения слуха, бруксизм, переломы коронковой части зубов, реставраций, онемение и парестезии в области пальцев рук, головокружение и общую уста- 
лость. Все эти симптомы могут быть вызваны незначительным (от нескольких микрон до 1мм) отклонением нижней челюсти в положении физиологического покоя.

Жалобы больных на слабость, недомогание, повышение температуры, асимметрию лица, боли при открывании рта в области височнонижнечелюстного сустава, утреннюю скованность, шумовые реакции в области сустава, ограничение подвижности нижней челюсти, невозможность длительно пережевывать пищу (ревматоидный артрит ВНЧС), болью в обоих височно-нижнечелюстных, а также других, особенно крупных суставах (ревматический артрит ВНЧС). При артрозе боль усиливается к вечеру, для бруксизма характерна боль во время или после сна. При артрите, как и при воспалении пульпы зуба, тканей периодонта, альвеолите, перекоронорите, папиллитете, наблюдается острая, тупая, ноющая, стреляющая, иррадиирующая боль. Такая же боль наблюдается и при неврите лицевого нерва, невралгии тройничного нерва, синусите. Затруднение, либо невозможность с силой сомкнуть зубные ряды, определяется при парафункции мышц, опускающих нижнюю челюсть. При остром бактериальном артрите, артрозах наблюдаются непроизвольные движения языка, мнимое жевание, утомляемость мышц, наличие болевых ощущений в мышцах, на лице, в области ВНЧС, а также боль, усиливающаяся при малейшей попытке движения нижней челюсти, которая иррадиирует в ухо, височную область, шею.

При артрозах утром больной чувствует заметное улучшение. Типичны стартовые боли, возникающие при первых движениях нижней челюсти, затем сустав как бы разрабатывается. Отмечается чувство усталости жевательных мышц, и боль в височной области при приеме твердой пищи. Нередко при артрозах ВНЧС больные предъявляют жалобы на появления парестезии кожи лица в околоушно-суставной области, что связывают с невритом ушно-височного нерва. Кроме того, наблюдаются иррадиации боли на стороне больного сустава, головная боль, парестезия слизистой оболочки полости рта, понижение слуха, глоссалгия (артриты, артрозы), что также вызвано дегенеративными изменениями в шейном отделе позвоночника (остеохондроз).

Туберкулёзный артрит характеризуется умеренными, локальными болями, ограничением функции сустава, наличием абсцессов с образованием свищей на коже лица и наружного слухового прохода. При актиномикотическом артрите наблюдаются синюшность кожных покровов, контрактуры жевательных мышц, наличие плотных, длительно развивающиеся инфильтратов, периодическим обострением процесса с образованием свищей с «пышными» грануляциями. Вывихи, подвывихи характеризуются щелканьем в суставах различной интенсивности, непривычными движениями нижней челюсти (плавные, зигзагообразные, круговые, толчкообразные, движение нижней челюсти в сторону) облизыванием губ, упором кончиком языка в щеку во время покоя нижней челюсти. 
Патологические процессы, развивающиеся в челюстно-лицевой области, в большинстве случаев бывают признаками воспаления, чаще одонтогенной природы. Они отличаются определенным характером болей, что может служить основанием для дифференциальной диагностики некоторых заболеваний. Субъективные симптомы являются отражением объективных процессов в организме и зубочелюстной системе, однако трактовка их зависит от состояния нервной системы.

\section{1. ОСТРАЯ БОЛЬ}

Для острых форм пульпита К04.01 (МКБ-10) характерны следующие симптомы:

Самопроизвольная боль, возникающая без воздействия внешних раздражителей. Возникновение самопроизвольных болей объясняется многими причинами - нарушением кровообращения, раздражением нервных окончаний бактериальными токсинами и продуктами распада органической субстанции дентина и пульпы, изменением $\mathrm{pH}$ в очаге воспаления и др.

Приступообразный характер болей, т.е. частое чередование болей с безболевыми промежутками, характерен для острого пульпита и обострений хронического пульпита. Такое чередование связано, вероятно, с адаптационной способностью организма к восприятию длительной боли, переутомляемостью нервной системы, периодическим сдавлением нервных рецепторов в результате отека пульпы и т.д.

Усиление болей ночью характерно для острого пульпита и обострения хронического пульпита. Известно, что симптом боли, сопровождающий любое заболевание, ночью воспринимается сильнее, чем днем. Это объясняется превалированием в ночное время деятельности парасимпатической нервной системы над симпатической системой. Усиление болей также связано с замедлением ночью ритма сердечной деятельности, а, следовательно, и кровообращения, что ведет к накоплению в пульпе токсических продуктов обмена, вызывающих раздражение нервных рецепторов.

Действие раздражителей - механических, химических и температурных - при кариесе вызывают кратковременную боль, которая ликвидируется немедленно после прекращения действия раздражителя. При пульпите, наоборот, болевой приступ продолжается и после устранения раздражителя. Болевая реакция при пульпите возникает обычно и от воздействия весьма слабых раздражителей. Так, если здоровая пульпа воспринимает тепло при температуре $50-60^{\circ} \mathrm{C}$ и ощущает холод при $15-20^{\circ} \mathrm{C}$, то диапазон температурных колебаний, на который отвечает воспаленная пульпа, значительно сужается и орошение зуба водой температуры 28 $30^{\circ} \mathrm{C}$ уже вызывает боль.

Боли, которые связаны с первичной дисфункцией скелетной мускулатуры, часто остаются нераспознанными, так как связаны с объективны- 
ми диагностическими трудностями, и с малой информированностью врачей о триггерных точках и миофасциальных болях.

Триггерная точка - участок повышенной чувствительности (гиперраздражимая область) в пределах локального мышечного уплотнения, проявляющийся резкой болезненностью при пальпации и принимающий участие в различных мышечно-тонических и вегетативных реакциях (синонимы: локальный гипертонус мышцы, миофасциальная триггерная точка).

Триггерные точки могут формироваться практически во всех мягких тканях (в том числе и в фасциях), но преобладают в крупных скелетных мышцах, выполняющих статические функции. Наиболее часто тригерные точки встречаются в мышцах шеи и плечевого пояса (трапециевидная, ротаторы шеи, лестничные, поднимающая лопатку, надлопаточная, надостная, подостная мышцы), а также в области таза и в жевательной мускулатуре.

Большое значение в развитии триггерных точек имеют однотипные движения; длительное, вынужденное положение тела или отдельных его частей (статические позно-тонические перегрузки мышц); в т.ч. значительные кинетические напряжения опорно-двигательного аппарата; неравномерный ритм рабочих операций, травмы, микротравмы.

Триггерные точки главным образом образуются от перенапряжения мышц, которое бывает при статических нарушениях, нарушении осанки, заболеваниях опорно-двигательного аппарата, неврологических заболеваниях и после травм. У больных с дисфункцией височно-челюстного сустава и болевой иррадиацией выявляется дискоординация активности жевательных мышц. Боль, вызванная ишемией мышцы, приводит к серьезному нарушению почерка, тогда как такая же ишемия без боли не нарушает почерка.

Проявлениями болевого фактора триггерных точек могут быть рецидивы хронических висцеральных заболеваний, а также переохлаждение и аллергия.

\section{2. Триггерные точки крыловидной, височной, жевательной мышц}

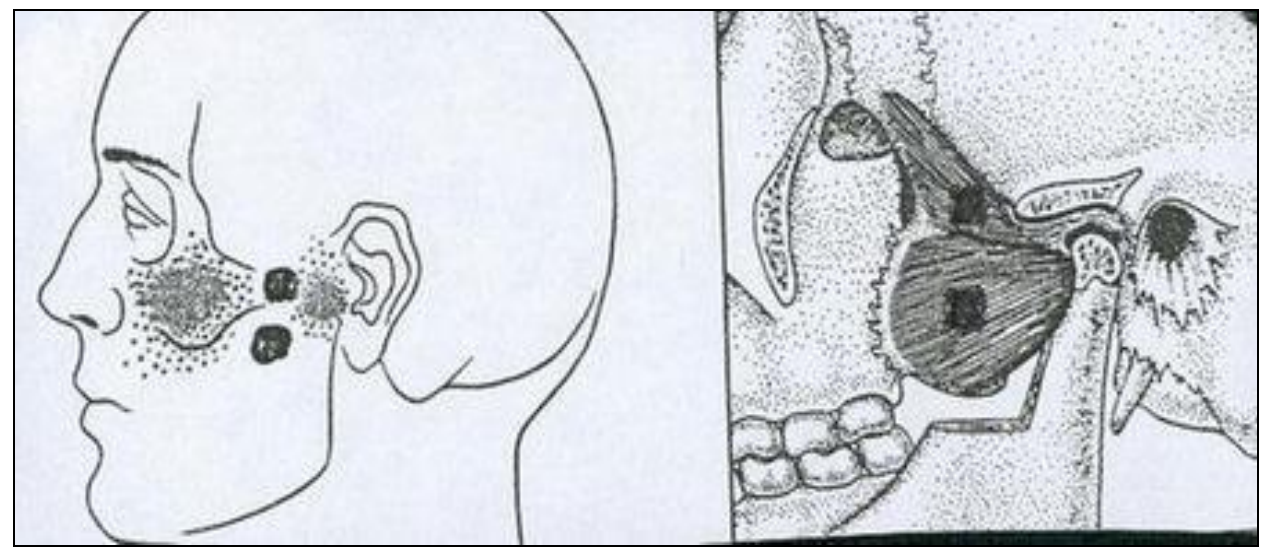

Рис. 12. Схема распространения боли при локализации триггерных точек в разных частях латеральной крыловидной мышцы. 


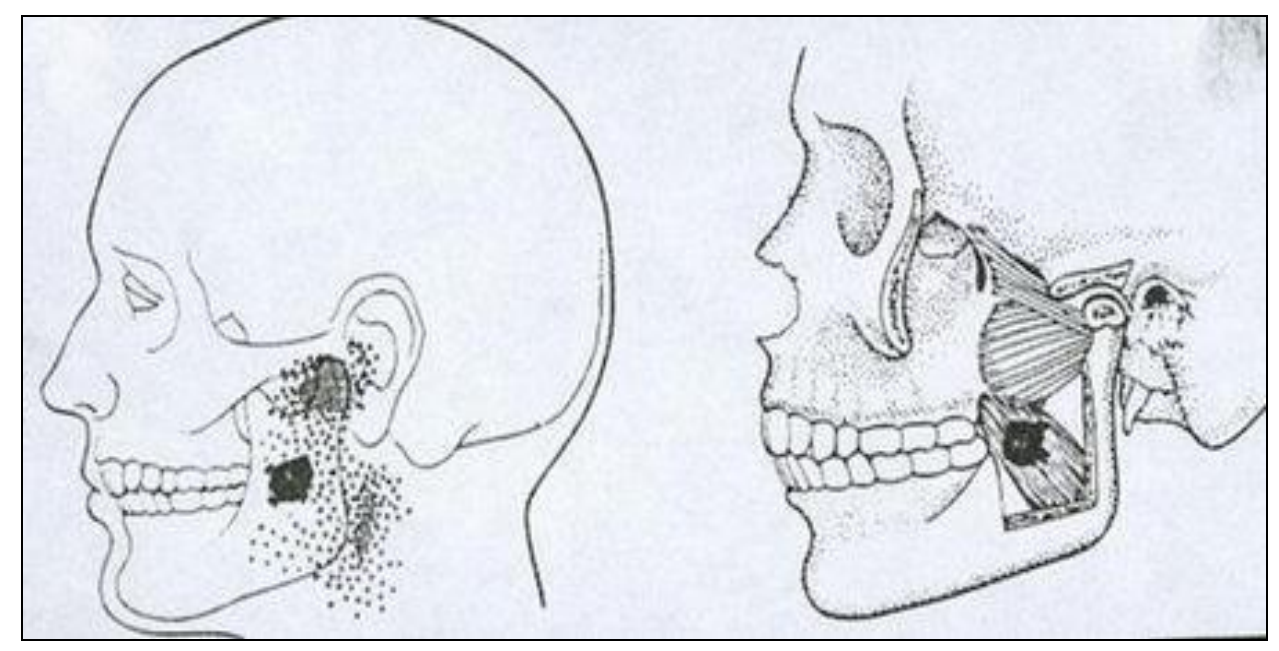

Рис. 13. Схема распространения боли при локализации триггерных точек в разных частях медиальной крыловидной мышцы.

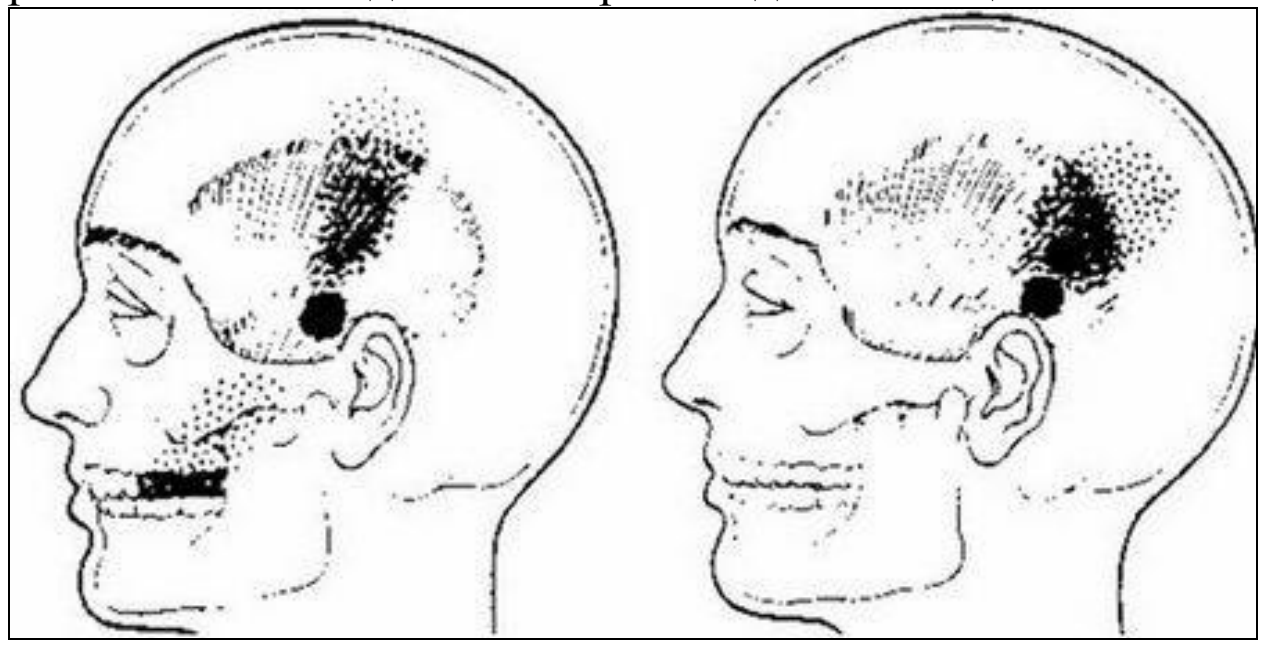

Рис. 14. Схема распространения боли при локализации триггерных точек в разных частях височной мышцы.

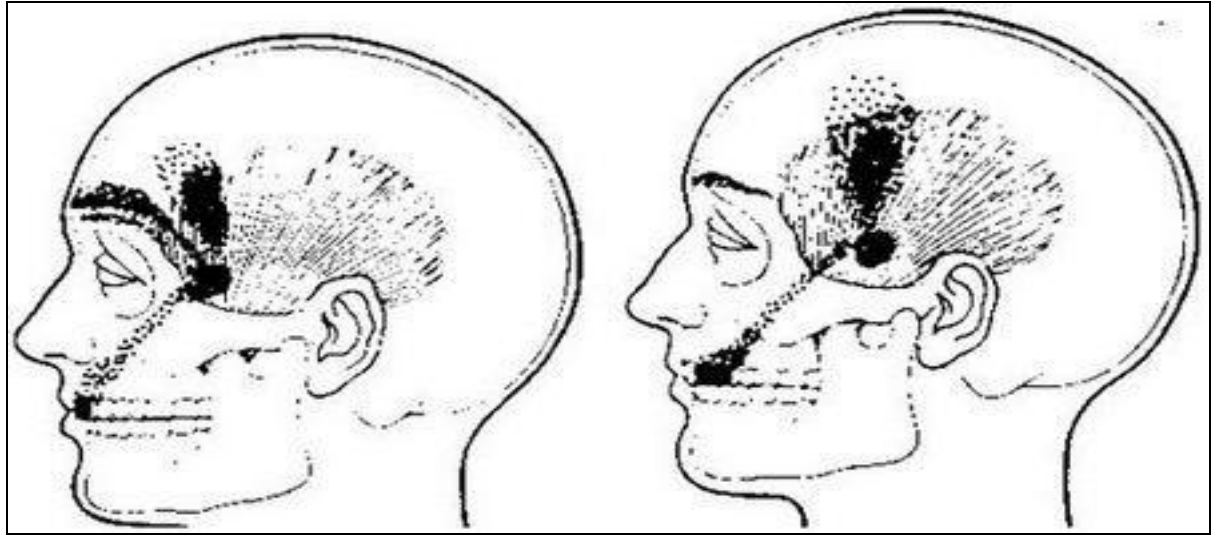

Рис.15. Схема распространения боли при локализации триггерных точек в разных частях височной мышцы. 


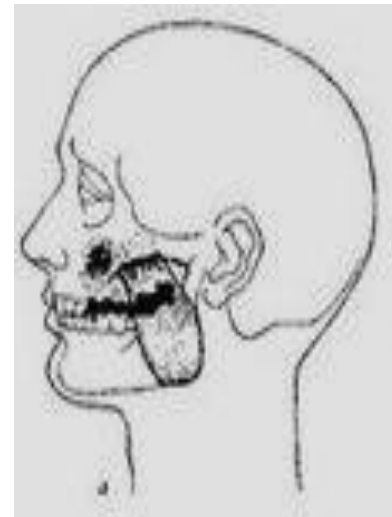

a

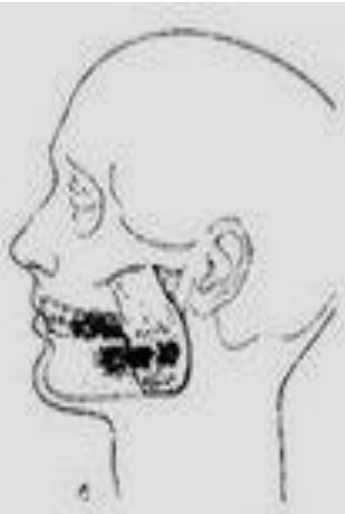

6

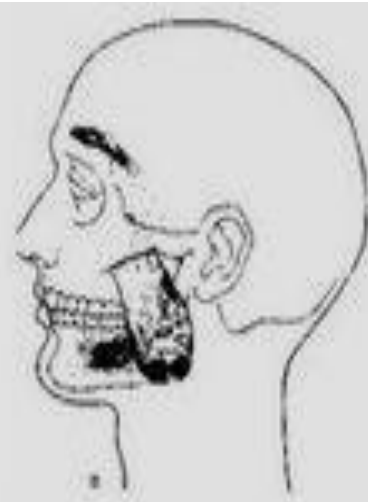

B

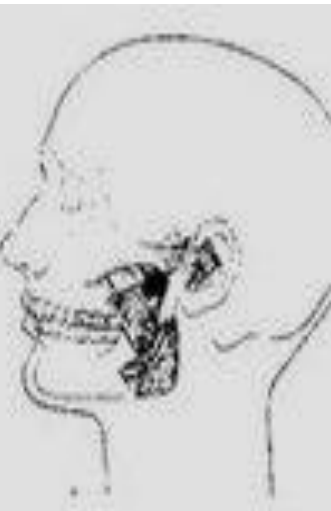

$\Gamma$

Рис. 16. Схема распространения боли при локализации триггерных точек в разных частях жевательной мышцы

Боль в области височно-нижнечелюстного сустава (ВНЧС), жевательных и височных мышцах может быть следствием нарушения окклюзионных взаимоотношений зубных рядов, уменьшения межальвеолярной высоты из-за стираемости зубов или дефектов в зубных рядах. Врачу необходимо уточнить локализацию боли, ее характер и интенсивность.

Критерии диагностики миофасциального синдрома: жалобы на региональную боль; пальпируемый «тугой» тяж в мышце; в пределах «тугого» тяжа имеется участок повышенной чувствительности; характерный паттерн отраженной боли или чувствительных расстройств; ограничение объема движений.

\section{3. Парестезии}

Жалобы на жжение, покалывание, саднение, онемение, пощипывание, чувство жара, боли ломящего, давящего характера в языке и на нёбе. Нарушение вкусовых ощущений, набухание, тяжесть, неловкость, невнятная речь, симптом щажения языка.

Диагностические признаки К14.68 (МКБ-10) глоссалгии, К14.61 (МКБ-10) глоссодинии и К14.0 (МКБ10) глоссита.

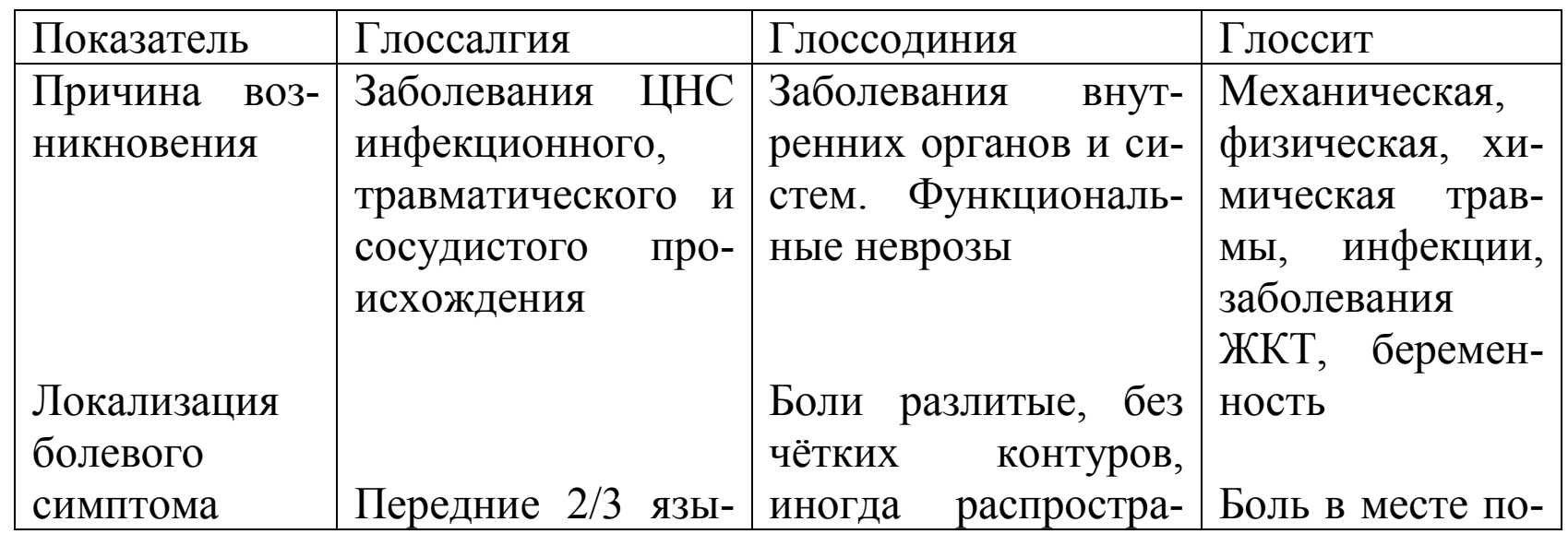




\begin{tabular}{|c|c|c|c|}
\hline & $\begin{array}{l}\text { ка, весь язык, ко- } \\
\text { рень языка }\end{array}$ & $\begin{array}{l}\text { няются на слизистую } \\
\text { полости рта, нёба }\end{array}$ & вреждения \\
\hline $\begin{array}{l}\text { Характер } \\
\text { ощущений }\end{array}$ & $\begin{array}{l}\text { Набухание, тя- } \\
\text { жесть, неловкость, } \\
\text { невнятная речь, } \\
\text { симптом щажения } \\
\text { языка. Боль во } \\
\text { время еды не ис- } \\
\text { чезает }\end{array}$ & $\begin{array}{l}\text { Жжение, покалыва- } \\
\text { ние, саднение, оне- } \\
\text { мение, пощипыва- } \\
\text { ние, чувство жара, } \\
\text { боли ломящего, да- } \\
\text { вящего характера. } \\
\text { Боль во время еды } \\
\text { исчезает }\end{array}$ & $\begin{array}{l}\text { Ноющая боль, } \\
\text { во время еды } \\
\text { усиливается } \\
\text { под влиянием } \\
\text { механических, } \\
\text { физических, хи- } \\
\text { мических фак- } \\
\text { торов }\end{array}$ \\
\hline $\begin{array}{l}\text { Вегетативные } \\
\text { расстройства }\end{array}$ & $\begin{array}{l}\text { Гиперемия или по- } \\
\text { бледнение слизи- } \\
\text { стой языка или по- } \\
\text { лости рта, отёч- } \\
\text { ность языка и щек }\end{array}$ & $\begin{array}{l}\text { Ксеростомия, осо- } \\
\text { бенно ночью }\end{array}$ & Нет \\
\hline $\begin{array}{l}\text { Влияние ане- } \\
\text { стезирующих } \\
\text { веществ на } \\
\text { болевой } \\
\text { симптом }\end{array}$ & $\begin{array}{l}\text { Боль исчезает по- } \\
\text { сле блокады регио- } \\
\text { нарных, ганглио- } \\
\text { нарных, перивас- } \\
\text { кулярных, вегета- } \\
\text { тивных или симпа- } \\
\text { тических нервных } \\
\text { образований }\end{array}$ & $\begin{array}{l}\text { Блокада нервных об- } \\
\text { разований не даёт } \\
\text { длительного лечеб- } \\
\text { ного эффекта }\end{array}$ & $\begin{array}{l}\text { Кратковремен- } \\
\text { ное исчезнове- } \\
\text { ние боли после } \\
\text { аппликационной } \\
\text { анестезии }\end{array}$ \\
\hline
\end{tabular}

\section{4. Нарушения конфигурации лица: острые одонтогенные воспалительные заболевания}

Для острого периодонтита К04.4 (МКБ-10) характерны острые, локализованные боли в зубе, боли при накусывании. Далее они усиливаются, становятся постоянными и иррадиируют по ходу ветвей чувствительных нервов.

Острый гнойный периостит К04.7 (МКБ-10) челюсти проявляется распространением боли от причинного зуба на участок челюсти, т.е. боль носит разлитой характер. Боли при остром остеомиелите челюсти в зависимости от локализации процесса и протяженности поражения кости разнообразны: острые, иррадиирущие по ходу нервов, сверлящие, разлитые.

Абсцессы, острый лимфаденит, специфические воспалительные процессы головы, шеи, челюстей характеризуются болями ноющего характе- 
ра, локализующимися в участке пораженных тканей. При пальпации они могут усиливаться.

При флегмоне К12.2 (МКБ-10), аденофлегмоне, фурункулах, карбункулах боли носят разлитой, постоянный характер. В дальнейшем интенсивность болей усиливается, они становятся дергающими, пульсирующими. Помимо локальных болей, при воспалительных процессах наблюдаются головные боли, недомогание, потеря аппетита, сна, озноб и другие проявления, отражающие степень интоксикации. Болевые ощущения могут возникать при движении нижней челюсти, языка, глотании, дыхании, разговоре. Это наблюдается при воспалительных, онкологических заболеваниях, травмах мягких и костных тканей лица, органов полости рта. Возможно нарушение жевания, глотания, открывания рта, вкуса, дыхания. Затрудненное глотание, дыхание - симптомы, при которых требуется безотлагательное дальнейшее обследование больного.

Фурункулы и карбункулы в 64,2\% случаев локализуются на лице, чаще всего локализуются в периорбитальной, щечной, подглазничной областях и верхней губе.

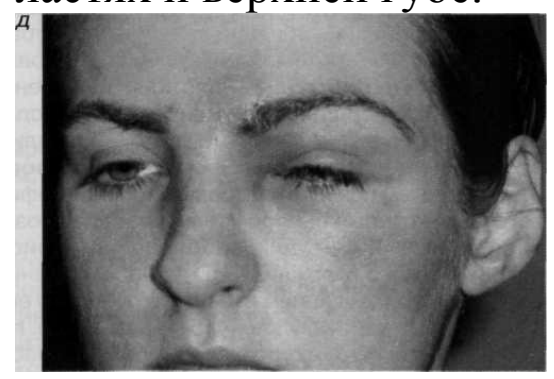

Рис. 17. Фурункул надбровной области.

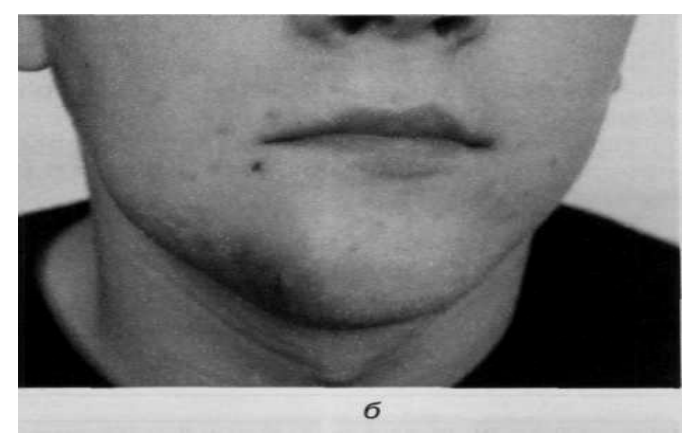

Рис. 18. Фурункул подбородка.

Карбункулы - на верхней и нижней губе, области подбородка 


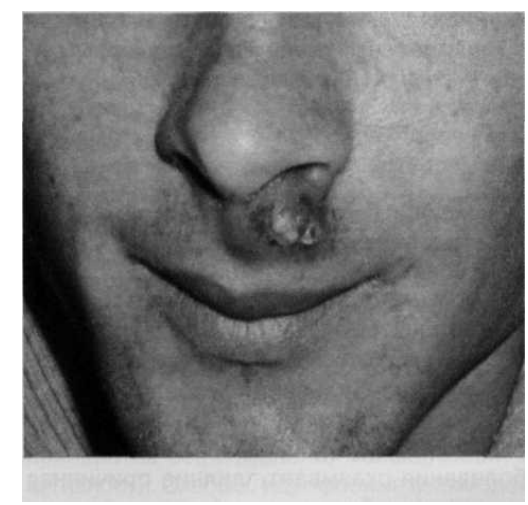

Рис. 19. Карбункул верхней губы.

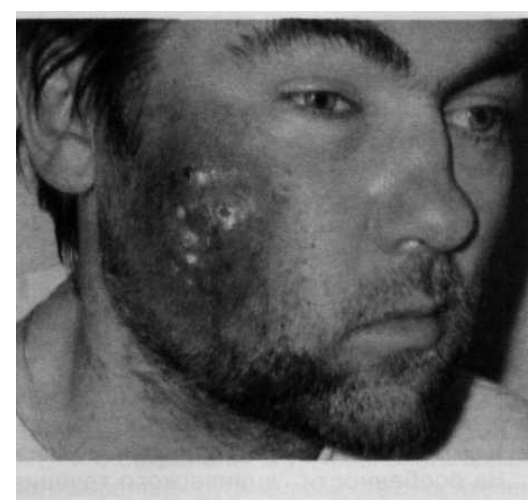

Рис. 20. Карбункул щеки.

Одонтогенные абсцессы и флегмоны делят на три группы.

1. Абсцессы и флегмоны К12.2 (МКБ-10), располагающиеся около нижней челюсти. Поверхностные - расположены в подчелюстной, подподбородочной, околоушно-жевательной областях. Глубокие - крыловидно-челюстного, окологлоточного, подъязычного пространства и дна полости рта.

2. Абсцессы и флегмоны, располагающиеся около верхней челюсти. Поверхностные находятся в подглазничной, щёчной областях; глубокие - в подвисочной, крыло-нёбной ямках.

3. Абсцессы и флегмоны соседних с околочелюстными тканями областей (скуловой, височной, позаднечелюстной областей, глазницы, языка, шеи), куда гнойный процесс распространяется по протяжению.

По тяжести клинического течения всех больных с флегмонами челюстно-лицевой области разделяют на три группы:

1. - больные с флегмонами, локализующимися в одном клеточном пространстве;

2 - больные с тяжёлыми формами флегмон, вовлекающими два и более двух клеточных пространств;

3 - больные с флегмонами и сопутствующими общими заболеваниями (сахарный диабет, болезни крови, сердечно-сосудистая недостаточность и другие), отягощающими течение воспалительного процесса в челюстно-лицевой области. 
По сравнению с абсцессами флегмоны характеризуются более выраженными общими симптомами: головная боль, слабость, плохой сон, потеря аппетита, повышение температуры тела - 39-39 гр., лейкоцитоз, увеличение СОЭ (Приложение 4), нарушение иммунитета, белкового обмена и др. Одонтогенные флегмоны характеризуются быстро увеличивающейся, резко болезненной припухлостью в околочелюстных тканях. Следует отметить, что боль в причинном зубе значительно уменьшается, и он становится подвижным, но при обследовании соседних зубов изменений нет.

В диагностике одонтогенных флегмон имеют значение четыре местных признака, встречающиеся в различных комбинациях.

Первый признак, так называемого «причинного» зуба выявляется на основании жалоб больного, осмотра, инструментального обследования полости рта, рентгенографии даёт представление о распространении одонтогенной инфекции в ближайшее к зубу клетчатое пространство лица.

Второй признак - признак выраженности разлитого воспалительного уплотнения (инфильтрата) и окружающего его отёка мягких тканей околочелюстной области, покрытых напряжённой, лоснящейся, покрасневшей кожей, что характерно для поверхностных флегмон. При флегмонах глубоких клетчаточных пространств лица, мало доступных для осмотра и прощупывания, этот признак слабо выражен или отсутствует, что успокаивает больного, несмотря на постоянные боли.

Третий признак - нарушение двигательной функции нижней челюсти от ограничения до невозможности открывать рот - характерен для глубоких флегмон и абсцессов крыловидно-челюстного, жевательного, подъязычного пространств, подвисочной, крыло-нёбной и височной ямок, при которых гнойник располагается под жевательными мышцами.

Четвёртый местный признак - признак болезненного глотания отмечается при глубоких флегмонах и абсцессах крыловидно-челюстного, подъязычного пространств, дна полости рта и языка. У больных флегмоной окологлоточного пространства глотание не только болезненное, но и затрудненое, нарушается речь и дыхание.

Больные могут предъявлять жалобы на болезненность и припухание слюнных желез, сухость в полости рта, неприятный солоноватый привкус, связанный с приемом пищи, что характерно для заболеваний слюнных желез.

Больные нередко жалуются на нарушение симметрии лица. Это может происходить вследствие воспалительной отёчности мягких тканей лица, новообразования тканей лица, челюстей, деформации отдельных его участков, нарушения акта речи (из-за отсутствия фронтальных зубов или неправильно изготовленных протезов).

Сопоставляя жалобы на боли с характером припухлости, в одних случаях можно говорить о заболеваниях воспалительного характера, в других - об опухоли или опухолеподобном образовании, о заболеваниях ВНЧС и др. 
Схема ориентировочной основы действия по диагностике острых одонтогенных периоститов челюстей - К10.22(МКБ-10)

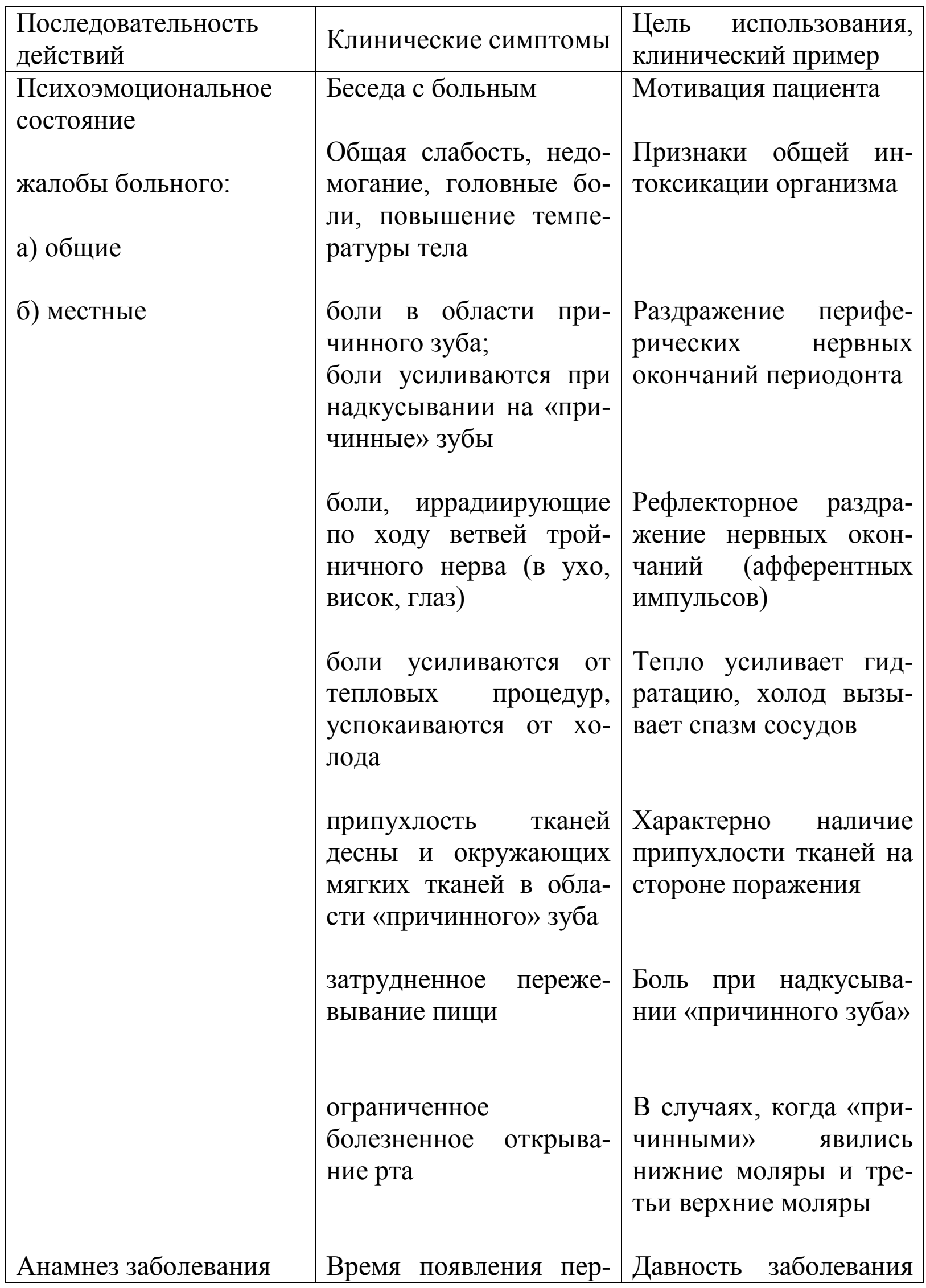




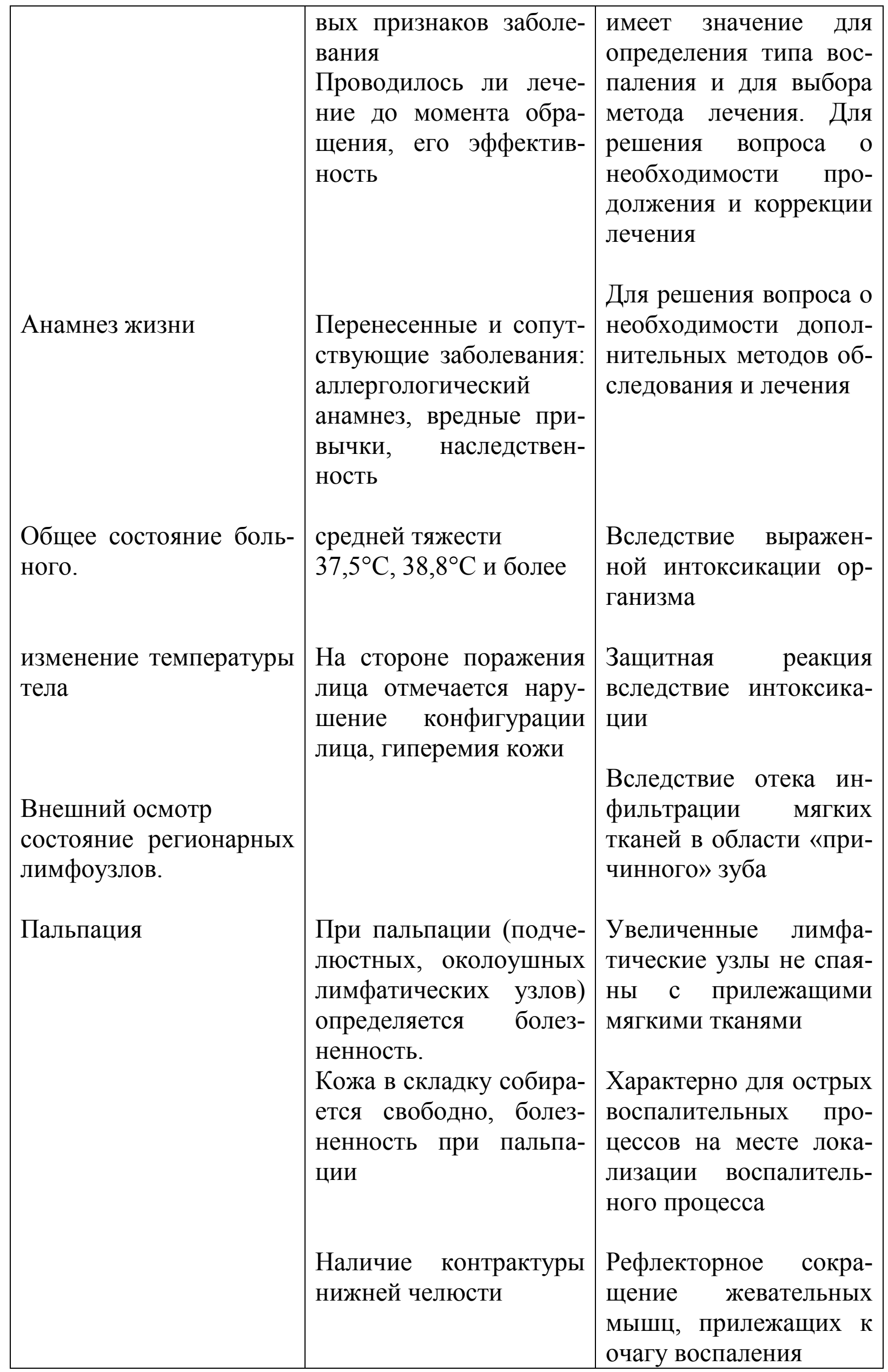




\begin{tabular}{|c|c|c|}
\hline Осмотр полости рта & $\begin{array}{l}\text { Нарушение (болезнен- } \\
\text { ное) глотания }\end{array}$ & $\begin{array}{l}\text { При периоститах, ис- } \\
\text { ходящих от третьих } \\
\text { моляров, отмечается } \\
\text { болезненное глотание } \\
\text { за счет вовлечения в } \\
\text { воспалительный про- } \\
\text { цесс тканей глоточного } \\
\text { кольца } \\
\text { Источником одонто- } \\
\text { генной инфекции яв- } \\
\text { ляются пораженные } \\
\text { кариесом зубы }\end{array}$ \\
\hline & $\begin{array}{l}\text { Наличие разрушенных } \\
\text { или подвижных зубов, } \\
\text { перкуссия «причинно- } \\
\text { го» зуба болезненна. } \\
\text { Подвижность зубов (I, } \\
\text { II, III степени) }\end{array}$ & $\begin{array}{l}\text { Раздражение вовле- } \\
\text { ченных в воспалитель- } \\
\text { ный процесс нервных } \\
\text { окончаний в периодон- } \\
\text { те, пародонте }\end{array}$ \\
\hline & $\begin{array}{l}\text { Гиперемия, отечность и } \\
\text { синюшность слизистой } \\
\text { оболочки переходной } \\
\text { складки в области } \\
\text { «причинных» зубов }\end{array}$ & $\begin{array}{l}\text { Расплавление гнойным } \\
\text { процессом тканей пе- } \\
\text { риодонта и пародонта, } \\
\text { характерные признаки } \\
\text { воспалительного про- } \\
\text { цесса }\end{array}$ \\
\hline $\begin{array}{l}\text { Предварительный диа- } \\
\text { гноз }\end{array}$ & & $\begin{array}{l}\text { Одонтогенный острый } \\
\text { периостит челюстей } \\
\text { (указать локализацию). }\end{array}$ \\
\hline $\begin{array}{l}\text { Дополнительные мето- } \\
\text { ды исследования }\end{array}$ & $\begin{array}{l}\text { Прицельная рентгено- } \\
\text { графия в области «при- } \\
\text { чинного» зуба. }\end{array}$ & $\begin{array}{l}\text { Для определения со- } \\
\text { стояния периодонта и } \\
\text { близлежащих костных } \\
\text { тканей. }\end{array}$ \\
\hline $\begin{array}{l}\text { Клинический } \text { анализ } \\
\text { крови }\end{array}$ & $\begin{array}{l}\text { Лейкоцитоз, } \\
\text { формулы } \\
\text { увеличенна. }\end{array}$ & $\begin{array}{l}\text { Резко выраженная ин- } \\
\text { токсикация организма. }\end{array}$ \\
\hline $\begin{array}{l}\text { Клинический } \text { анализ } \\
\text { мочи }\end{array}$ & Наличие белка в моче & $\begin{array}{l}\text { Резко выраженная ин- } \\
\text { токсикация организма }\end{array}$ \\
\hline
\end{tabular}


Невправляемый вывих суставного диска, его деформация характеризуется ограничением подвижности нижней челюсти вследствие механического препятствия при внутренних нарушениях в суставе, наблюдается деформация суставной головки, суставного бугорка при системных заболеваниях, артрозах и артритах.

Аускультативные признаки. Щелчки наблюдаются при нарушениях координированных движений между суставной головкой и суставным диском при внутренних нарушениях. Хруст связан с деформацией суставных поверхностей, уменьшением количества суставной жидкости, шум трения связан с уменьшением количества суставной жидкости.

\section{5. Травматические повреждения челюстно-лицевой области}

Схема ориентировочной основы действия по диагностике травматических повреждений челюстно-лицевой области -S02.4 (МКБ-10)

\begin{tabular}{|c|c|c|}
\hline $\begin{array}{l}\text { Последовательность } \\
\text { действий }\end{array}$ & $\begin{array}{l}\text { Клинические симпто- } \\
\text { мы }\end{array}$ & $\begin{array}{l}\text { Цель использования, } \\
\text { клинический пример }\end{array}$ \\
\hline \multirow[t]{2}{*}{$\begin{array}{l}\text { Опрос больного } \\
\text { Психоэмоциональное } \\
\text { состояние }\end{array}$} & Обеспокоенность & $\begin{array}{l}\text { Острая и хроническая } \\
\text { травма } \\
\text { лицевой областиюстно- }\end{array}$ \\
\hline & $\begin{array}{l}\text { Безразличие } \\
\text { Подавленность }\end{array}$ & $\begin{array}{l}\text { Хроническая интокси- } \\
\text { кация }\end{array}$ \\
\hline Жалобы & $\begin{array}{l}\text { На боль (локализация, } \\
\text { характер, нарушение } \\
\text { чувствительности) }\end{array}$ & $\begin{array}{l}\text { Боль является одним из } \\
\text { признаков травмы че- } \\
\text { люстно-лицевой обла- } \\
\text { сти, её интенсивный } \\
\text { характер зависит от ло- } \\
\text { кализации и степени } \\
\text { повреждения ткани }\end{array}$ \\
\hline $\begin{array}{l}\text { Изменение общего со- } \\
\text { стояния }\end{array}$ & $\begin{array}{l}\text { Головная боль, голо- } \\
\text { вокружение, рвота, ре- } \\
\text { троградная амнезия, } \\
\text { бессознательное со- } \\
\text { стояние }\end{array}$ & $\begin{array}{l}\text { Имеют большое значе- } \\
\text { ние в диагностике по- } \\
\text { вреждений ЦНС. } \\
\text { Травма не редко может } \\
\text { повлечь за собой функ- } \\
\text { циональное и космети- } \\
\text { ческое нарушение че- }\end{array}$ \\
\hline
\end{tabular}




\begin{tabular}{|c|c|c|}
\hline & & люстно-лицевой \\
\hline Анамнез заболевания & $\begin{array}{l}\text { Время получения } \\
\text { травмы, механизм по- } \\
\text { лучения травмы, ок- } \\
\text { зание первой помощи }\end{array}$ & $\begin{array}{l}\text { Выяснение этих дан- } \\
\text { ных имеет значение } \\
\text { для оказания квалифи- } \\
\text { цированной помощи }\end{array}$ \\
\hline Анамнез жизни & $\begin{array}{l}\text { Перенесенные и со- } \\
\text { путствующие заболе- } \\
\text { вания, вредные при- } \\
\text { вычки }\end{array}$ & $\begin{array}{l}\text { Необходимо учиты- } \\
\text { вать, т.к. заболевания } \\
\text { крови, сердечно- } \\
\text { сосудистые заболева- } \\
\text { ния, сахарный диабет, } \\
\text { болезни печени влияют } \\
\text { на течение и заживле- } \\
\text { ние повреждений че- } \\
\text { люстно-лицевой } \\
\text { области }\end{array}$ \\
\hline $\begin{array}{l}\text { Аллергологический } \\
\text { анамнез }\end{array}$ & $\begin{array}{l}\text { Опрос больных (со- } \\
\text { провождающих лиц } \\
\text { при бессознательном } \\
\text { состоянии больного) }\end{array}$ & $\begin{array}{l}\text { Имеет значение для } \\
\text { выбора метода обезб- } \\
\text { ливания и медикамен- } \\
\text { тозного лечения }\end{array}$ \\
\hline Осмотр & $\begin{array}{l}\text { Сознание, } \\
\text { рефлексы. } \\
\text { Реакция зрачков } \\
\text { Температура тела } \\
\text { Пульс } \\
\text { АД } \\
\text { Наличие сопутствую- } \\
\text { щих повреждений }\end{array}$ & $\begin{array}{l}\text { Травма челюстно- } \\
\text { лицевой области может } \\
\text { сопровождаться сотря- } \\
\text { сением, ушибом голов- } \\
\text { ного мозга, внутриче- } \\
\text { репным кровоизлияни- } \\
\text { ем, переломом основа- } \\
\text { ния черепа. АД и } \\
\text { пульс характеризуют } \\
\text { повреждение ЦНС и } \\
\text { состояние сердечно- } \\
\text { сосудистой системы. } \\
\text { Повышение темпера- } \\
\text { туры тела может сви- } \\
\text { детельствовать о нали- } \\
\text { чии воспалительного } \\
\text { процесса }\end{array}$ \\
\hline Дыхание & & $\begin{array}{ll}\text { Может } & \text { быть результа- } \\
\text { том } & \text { возникновения }\end{array}$ \\
\hline
\end{tabular}




\begin{tabular}{|c|c|c|}
\hline & & $\begin{array}{lll}\text { препятствий в } & \text { дыха- } \\
\text { тельных путях } & \text { (ино- } \\
\text { родное тело, } & \text { отёк, } \\
\text { смещение тканей) }\end{array}$ \\
\hline Конфигурация лица & Форма лица изменена & $\begin{array}{l}\text { В результате отёка, } \\
\text { кровоизлияния, смеще- } \\
\text { ния костных фрагмен- } \\
\text { тов. При переломе } \\
\text { верхней челюсти по } \\
\text { типу ФОР ІІ и ФОР ІІІ } \\
\text { лицо удлиняется за } \\
\text { счёт смещения костных } \\
\text { фрагментов (отломков) } \\
\text { вниз }\end{array}$ \\
\hline $\begin{array}{l}\text { Цвет и состояние кож- } \\
\text { ных покровов }\end{array}$ & $\begin{array}{l}\text { Наличие кровотечения } \\
\text { или следов крови, } \\
\text { подкожное кровоизли- } \\
\text { яние. }\end{array}$ & $\begin{array}{l}\text { Хорошее кровоснабже- } \\
\text { ние челюстно-лицевой } \\
\text { области обуславливает } \\
\text { быстрое развитие кро- } \\
\text { воподтёков, особенно } \\
\text { часто в области век } \\
\text { «симптом очков». Тип } \\
\text { перелома ФОР II и } \\
\text { ФОР III }\end{array}$ \\
\hline Выражение лица. & & $\begin{array}{l}\text { Лицо может приобре- } \\
\text { тать страдальческое } \\
\text { выражение }\end{array}$ \\
\hline Открывание рта & $\begin{array}{l}\text { Открывание рта огра- } \\
\text { ничено }\end{array}$ & $\begin{array}{l}\text { За счёт болезненности } \\
\text { и смещения костных } \\
\text { обломков }\end{array}$ \\
\hline $\begin{array}{l}\text { Осмотр полости рта. } \\
\text { Состояние слизистой } \\
\text { оболочки, полости рта } \\
\text { (зубы, язва). }\end{array}$ & $\begin{array}{l}\text { Нарушение целостно- } \\
\text { сти слизистой оболоч- } \\
\text { ки полости рта }\end{array}$ & $\begin{array}{l}\text { Может свидетельство- } \\
\text { вать об открытом пере- } \\
\text { ломе челюстей. }\end{array}$ \\
\hline Пальпация и перкуссия: & $\begin{array}{l}\text { 1. Болезненность } \\
\text { 2. Консистенция } \\
\text { 3. Деформация }\end{array}$ & $\begin{array}{lr}\text { Данные } & \text { симптомы яв- } \\
\text { ляются } & \text { характерными } \\
\text { для } & \text { перелома } \\
\text { челюстей } & \end{array}$ \\
\hline
\end{tabular}




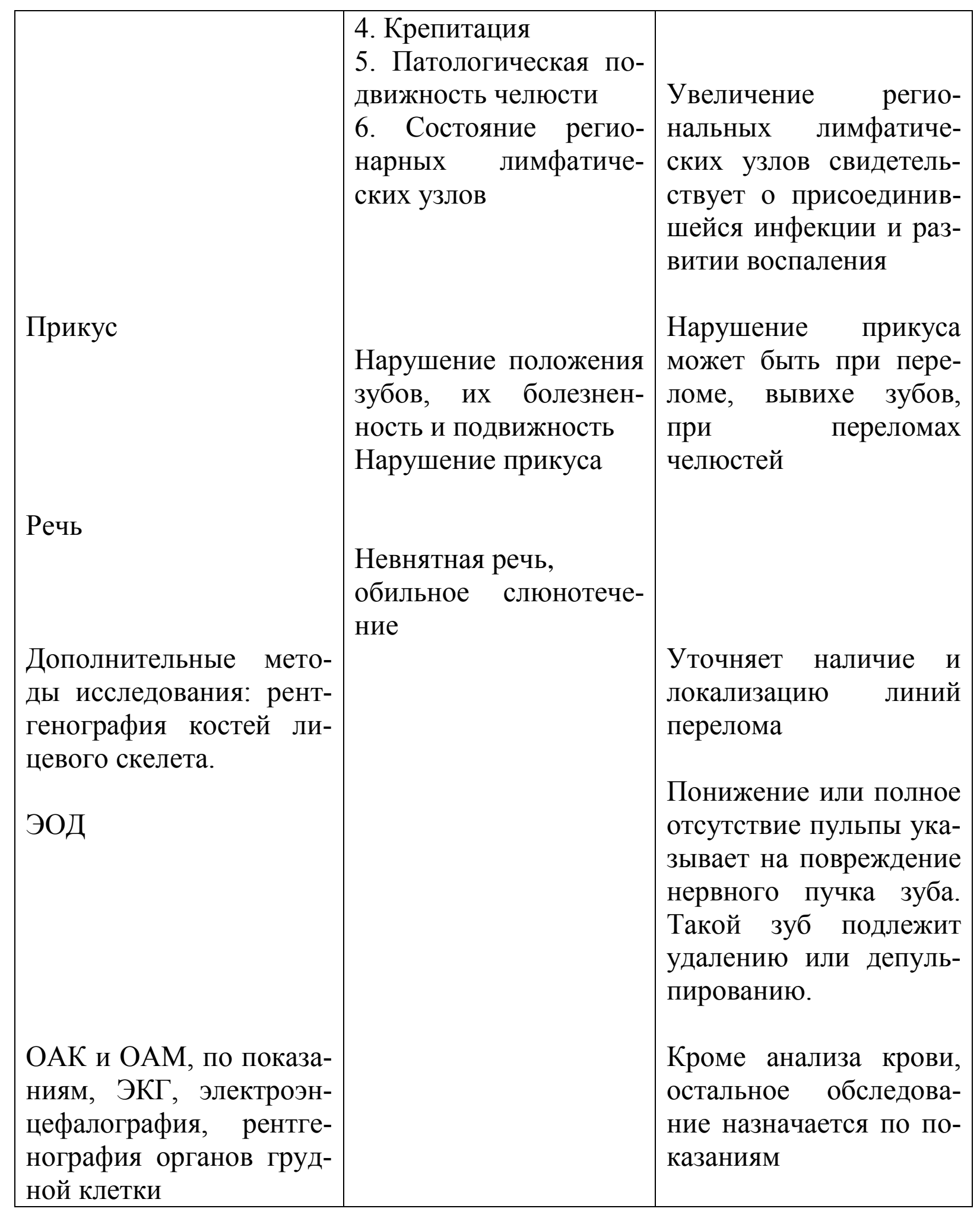




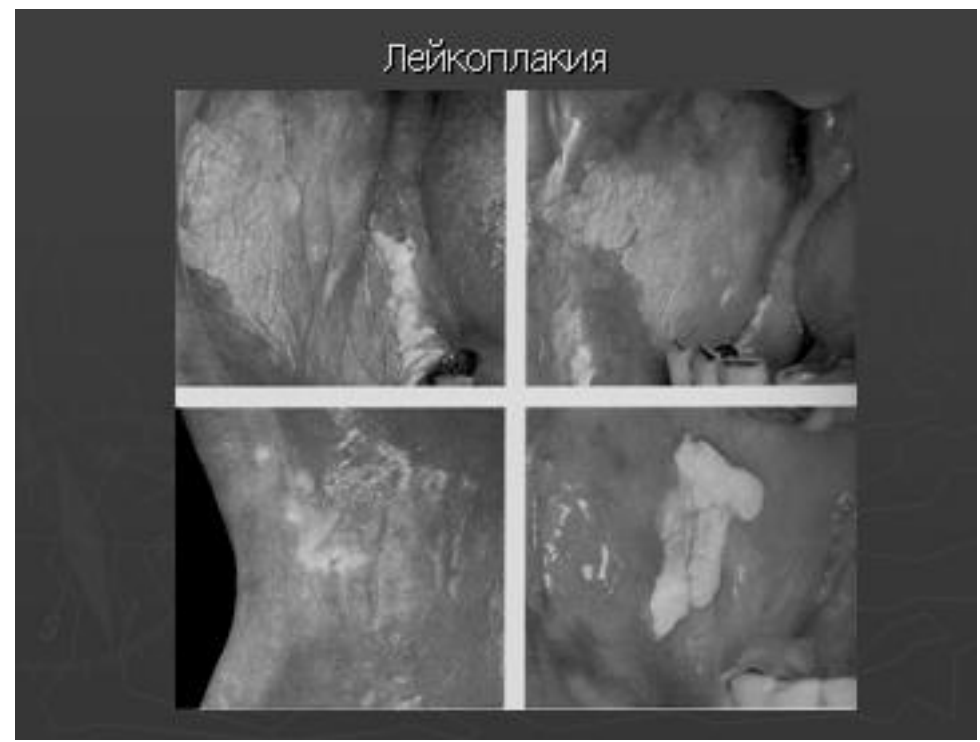

Рис. 21. Морфологические элементы, их проявления при заболеваниях СОПР, языка, губ.

\section{6. Опухолевые процессы в челюстно-лицевой области}

Нередко опухолевые процессы в челюстно-лицевой области выявляются впервые врачом-стоматологом при обращении пациента с другим заболеванием: заболеваниями твёрдых тканей зуба, пародонта, заболеваниями слизистой полости рта, языка, после восстановления целостности зубного ряда (при частичном отсутствии зубов), полного съёмного протезирования и др.

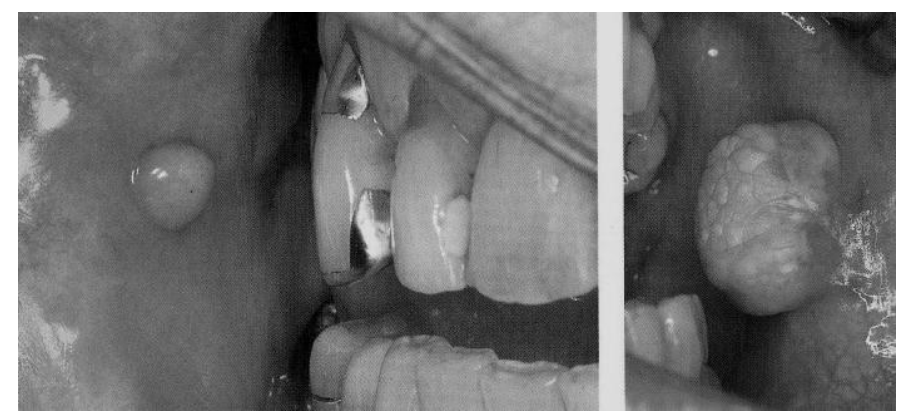

Рис. 22. Фиброма - К12.12(МКБ-10). 


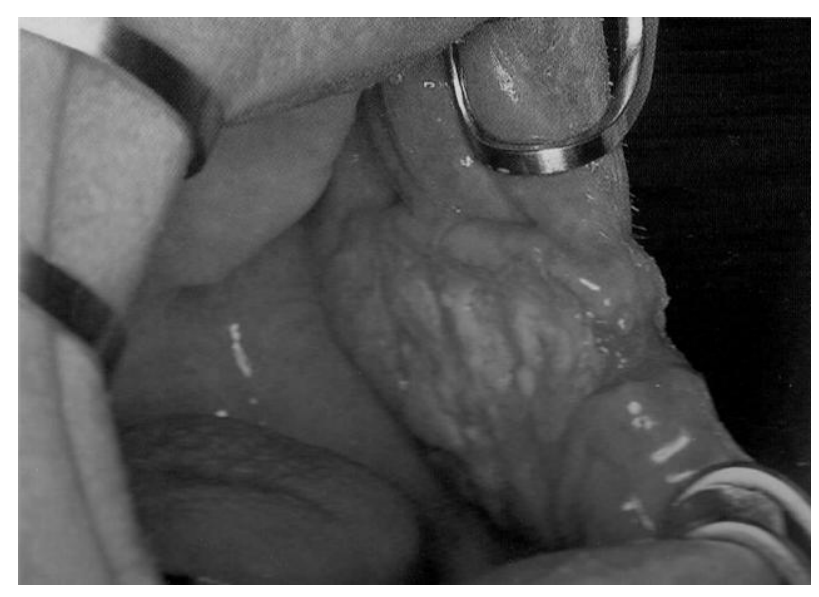

Рис. 23. Карцинома слизистой оболочки щеки.

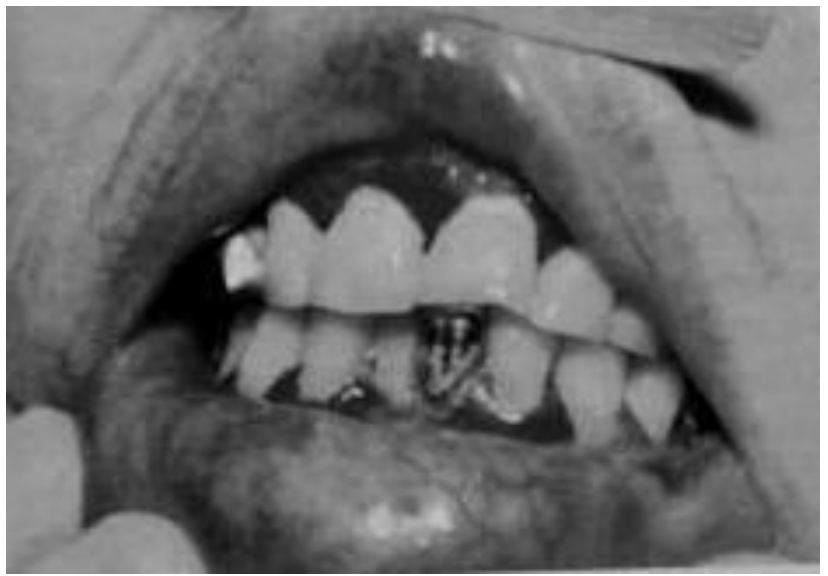

Рис. 24. Экссудативно-гиперемическая форма красного плоского лишая К12 нередко трансформируется в эрозивно-язвенную форму.

Схема ООД. Методы обследования с целью диагностики заболеваний слизистой полости рта К12 (МКБ-10), языка К14.0 (МКБ-10), губ К13.0 (МКБ10)

\begin{tabular}{|l|l|l|l|}
\hline № & $\begin{array}{l}\text { Последовательность } \\
\text { обследования }\end{array}$ & $\begin{array}{l}\text { Клинические } \\
\text { симптомы }\end{array}$ & $\begin{array}{l}\text { Цель использования, } \\
\text { клинический пример }\end{array}$ \\
\hline 1 & $\mathbf{2}$ & $\mathbf{3}$ & $\mathbf{4}$ \\
\hline 1. & $\begin{array}{l}\text { Опрос больного } \\
\text { I. Жалобы }\end{array}$ & $\begin{array}{l}\text { Боль в каком-либо } \\
\text { участке слизистой } \\
\text { оболочки полости } \\
\text { рта }\end{array}$ & $\begin{array}{l}\text { Раздражение, давление } \\
\text { нервных окончаний при } \\
\text { воспалении и других па- } \\
\text { тологических процессах }\end{array}$ \\
& $\begin{array}{l}\text { Неприятные ощу- } \\
\text { щения (покалыва- } \\
\text { ния, жжения) }\end{array}$ & $\begin{array}{l}\text { Нарушение вегетатив- } \\
\text { ной иннервации (глос- } \\
\text { салгия), анемия, канди- } \\
\text { доз, съёмное или } \\
\text { несъёмное протезирова- }\end{array}$ \\
\hline
\end{tabular}




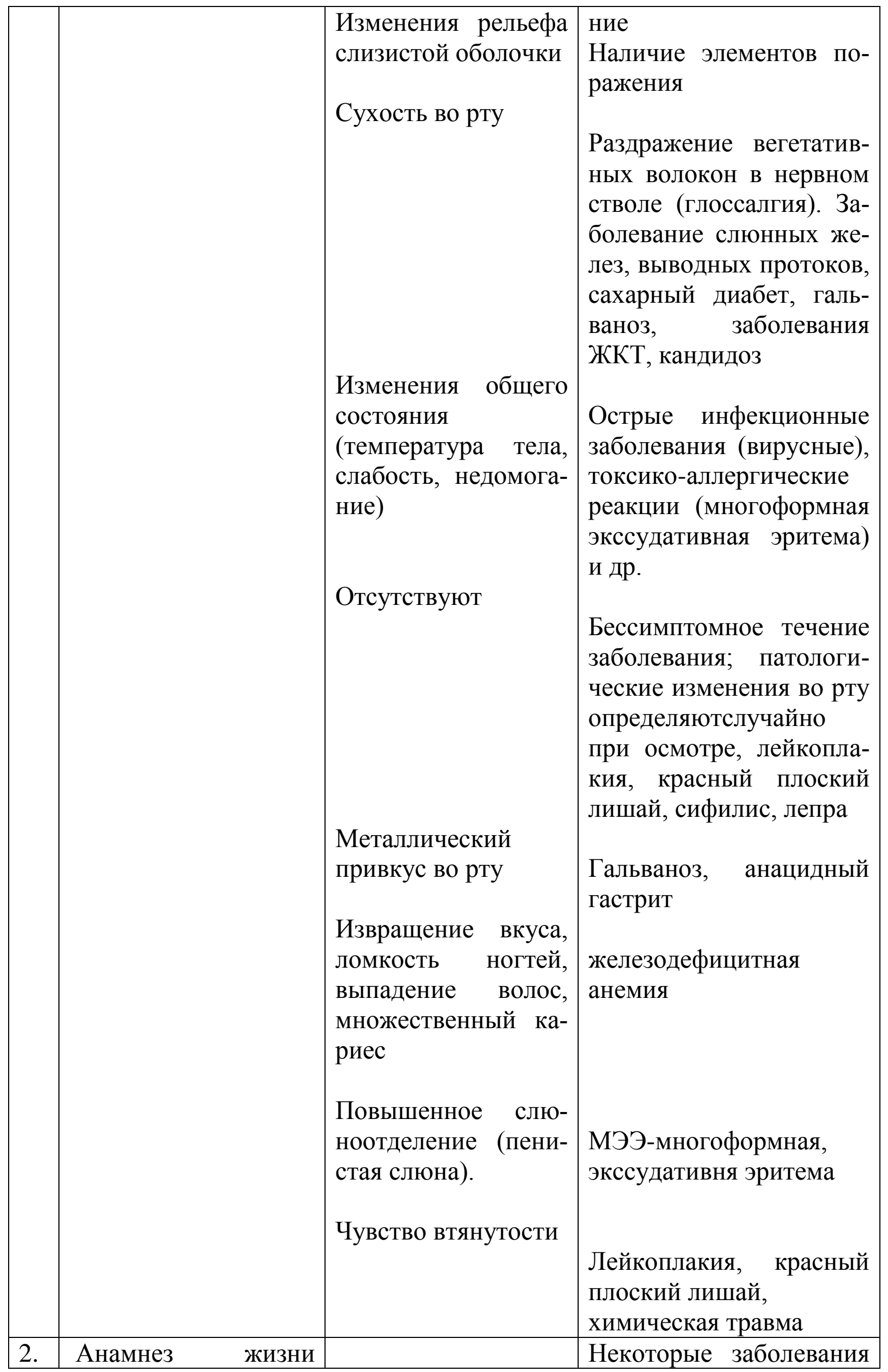




\begin{tabular}{|c|c|c|}
\hline $\begin{array}{l}\text { (an. } \\
\text { Пол, возраст }\end{array}$ & & 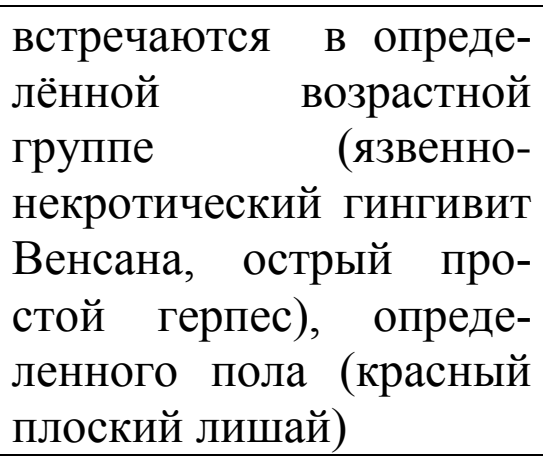 \\
\hline $\begin{array}{l}\text { Перенесенные и } \\
\text { сопутствующие } \\
\text { заболевания }\end{array}$ & $\begin{array}{l}\text { Заболевания желу- } \\
\text { дочно-кишечного } \\
\text { тракта, онколечение } \\
\\
\text { Эндокринные або- } \\
\text { левания (сахарный } \\
\text { диабет) } \\
\text { Заболевания крови } \\
\text { (лейкозы, анемии, } \\
\text { полицитемия и др.), } \\
\text { вирусный гепатит, } \\
\text { ТБС } \\
\text { Заболевания сер- } \\
\text { дечно-сосудистой } \\
\text { системы }\end{array}$ & $\begin{array}{l}\text { Глосситы, глоссодиния, } \\
\text { гиповитаминозы, заеда, } \\
\text { язвенно-некротические } \\
\text { поражения, заболевания } \\
\text { пародонта } \\
\text { Способствуют развитию } \\
\text { пародонтита, кандидоза, } \\
\text { красного плоского ли- } \\
\text { шая (КПЛ) } \\
\text { Имеют проявления в по- } \\
\text { лости рта }\end{array}$ \\
\hline $\begin{array}{l}\text { Профессиональные } \\
\text { вредности }\end{array}$ & $\begin{array}{l}\text { Химические пред- } \\
\text { приятия нефтепере- } \\
\text { рабатывающей про- } \\
\text { мышленности } \\
\text { Контакт с пестици- } \\
\text { дами } \\
\text { Контакт с радиоак- } \\
\text { тивными вещества- } \\
\text { ми, тяжелыми ме- } \\
\text { таллами } \\
\text { Работа на улице, в } \\
\text { поле }\end{array}$ & $\begin{array}{l}\text { Контакт с канцероген- } \\
\text { ными веществами спо- } \\
\text { собствует развитию } \\
\text { предраковых заболева- } \\
\text { ний, злокачественных } \\
\text { новообразований } \\
\text { Лучевая болезнь, отрав- } \\
\text { ление солями тяжелых } \\
\text { металлов: свинцом, } \\
\text { висмутом, ртутью } \\
\text { Повышенная инсоляция } \\
\text { предрасполагает к раз- }\end{array}$ \\
\hline
\end{tabular}




\begin{tabular}{|c|c|c|c|}
\hline & & & $\begin{array}{l}\text { витию предраковых за- } \\
\text { болеваний, к развитию } \\
\text { актинического, мете-- } \\
\text { рологического хейлита }\end{array}$ \\
\hline & Вредные привычки & $\begin{array}{l}\text { Курение, приём ал- } \\
\text { коголя, жевание } \\
\text { наркотических ве- } \\
\text { ществ }\end{array}$ & $\begin{array}{l}\text { Развитие предраковых } \\
\text { состояний слизистой } \\
\text { оболочки полости рта } \\
\text { (лейкоплакия, хейлит } \\
\text { Манганотти др.) }\end{array}$ \\
\hline & & $\begin{array}{l}\text { Привычное прику- } \\
\text { сывание слизистой }\end{array}$ & $\begin{array}{l}\text { Хроническая механиче- } \\
\text { ская травма (мягкая } \\
\text { лейкоплакия) }\end{array}$ \\
\hline & $\begin{array}{l}\text { Аллергологический } \\
\text { статус }\end{array}$ & $\begin{array}{l}\text { Аллергия к продук- } \\
\text { там питания, } \\
\text { к лекарствам, к бы- } \\
\text { товым веществам }\end{array}$ & $\begin{array}{l}\text { Развиваются } \text { и тяжелее } \\
\text { протекают } \text { различные } \\
\text { аллергические заболева- } \\
\text { ния (экзематозный хей- } \\
\text { лит) }\end{array}$ \\
\hline & Наследственность & $\begin{array}{l}\text { Наличие аналогич- } \\
\text { ной болезни у род- } \\
\text { ственников }\end{array}$ & $\begin{array}{l}\text { Буллезный эпидермолиз, } \\
\text { экзематозный хейлит }\end{array}$ \\
\hline 3. & $\begin{array}{l}\text { Развитие настоящего } \\
\text { заболевания } \\
\text { (an. morbi) }\end{array}$ & $\begin{array}{l}\text { Начальные симпто- } \\
\text { мы заболевания } \\
\text { Давность заболева- } \\
\text { ния, особенности } \\
\text { течения } \\
\text { Возможная причина } \\
\text { болезни } \\
\text { Частота рецидивов, } \\
\text { обследования } \\
\text { Эффективность } \\
\text { проводимого ранее } \\
\text { лечения }\end{array}$ & $\begin{array}{l}\text { Возможен продромаль- } \\
\text { ный период } \\
\text { Влияние на тяжесть, те- } \\
\text { чение заболевания, раз- } \\
\text { витие осложнений, на } \\
\text { выбор метода лечения } \\
\text { Травмирующий фактор } \\
\text { Характеризует тяжесть } \\
\text { течения заболевания } \\
\text { Позволяет подобрать } \\
\text { оптимальный метод ле- } \\
\text { чения и лекарственные } \\
\text { средства }\end{array}$ \\
\hline
\end{tabular}




\begin{tabular}{|c|c|c|}
\hline $\begin{array}{l}\text { Осмотр больного } \\
\text { А. } \\
\text { Внеротовая область } \\
\text { (кожные покровы) }\end{array}$ & $\begin{array}{lr}\text { Грудная } & \text { клетка, } \\
\text { предплечье, кисти, } \\
\text { сгибательная } \\
\text { верхность конечно- } \\
\text { стей, стопы }\end{array}$ & $\begin{array}{l}\text { Красный плоский ли- } \\
\text { шай, ящур, МЭЭ, хро- } \\
\text { нический рецедивиру- } \\
\text { ющий герпес (ХРГ), } \\
\text { опоясывающий лишай, } \\
\text { пузырчатка }\end{array}$ \\
\hline \multirow[t]{3}{*}{$\begin{array}{l}\text { Психоэмоциональное } \\
\text { состояние }\end{array}$} & Обеспокоенность & $\begin{array}{l}\text { Острая и хроническая } \\
\text { травма слизистой поло- } \\
\text { сти рта, язвенно- } \\
\text { некротический гингиво- } \\
\text { стоматит Венсана, глос- } \\
\text { салгия }\end{array}$ \\
\hline & Безразличие & $\begin{array}{l}\text { Хроническая интокси- } \\
\text { кация солями тяжелых } \\
\text { металлов, авитаминозы }\end{array}$ \\
\hline & Подавленность & $\begin{array}{l}\text { Хронический рецедиви- } \\
\text { рующий афтозный сто- } \\
\text { матит (ХРАС), раковая } \\
\text { язва, туберкулёзная язва } \\
\text { и т.д. }\end{array}$ \\
\hline \multirow[t]{2}{*}{$\begin{array}{l}\text { Состояние видимых } \\
\text { кожных покровов, } \\
\text { красной каймы губ и } \\
\text { видимых слизистых } \\
\text { оболочек носа, глаз }\end{array}$} & Цвет & $\begin{array}{l}\text { Цвет кожи изменен при } \\
\text { нарушении общего со- } \\
\text { стояния организма (бо- } \\
\text { лезни крови и др.) }\end{array}$ \\
\hline & $\begin{array}{l}\text { Наличие элементов } \\
\text { поражения на коже }\end{array}$ & $\begin{array}{l}\text { Красный плоский ли- } \\
\text { шай, красная волчанка, } \\
\text { пузырчатка, хрониче- } \\
\text { ский рецидивирующий } \\
\text { герпес, опоясывающий } \\
\text { лишай, ревматизм }\end{array}$ \\
\hline \multirow[t]{2}{*}{$\begin{array}{l}\text { Носогубная складка } \\
\text { Наличие: }\end{array}$} & $\begin{array}{l}\text { Наличие } \text { элементов } \\
\text { поражения r на } \\
\text { слизистой оболочке } \\
\text { глаз, носа }\end{array}$ & $\begin{array}{l}\text { Многоформная экссуда- } \\
\text { тивная эритема, пузыр- } \\
\text { чатка, вирусные пора- } \\
\text { жения, синдром Бехчета }\end{array}$ \\
\hline & Сглажена & $\begin{array}{l}\text { Неврит лицевого нерва, } \\
\text { острые одонтогенные }\end{array}$ \\
\hline
\end{tabular}




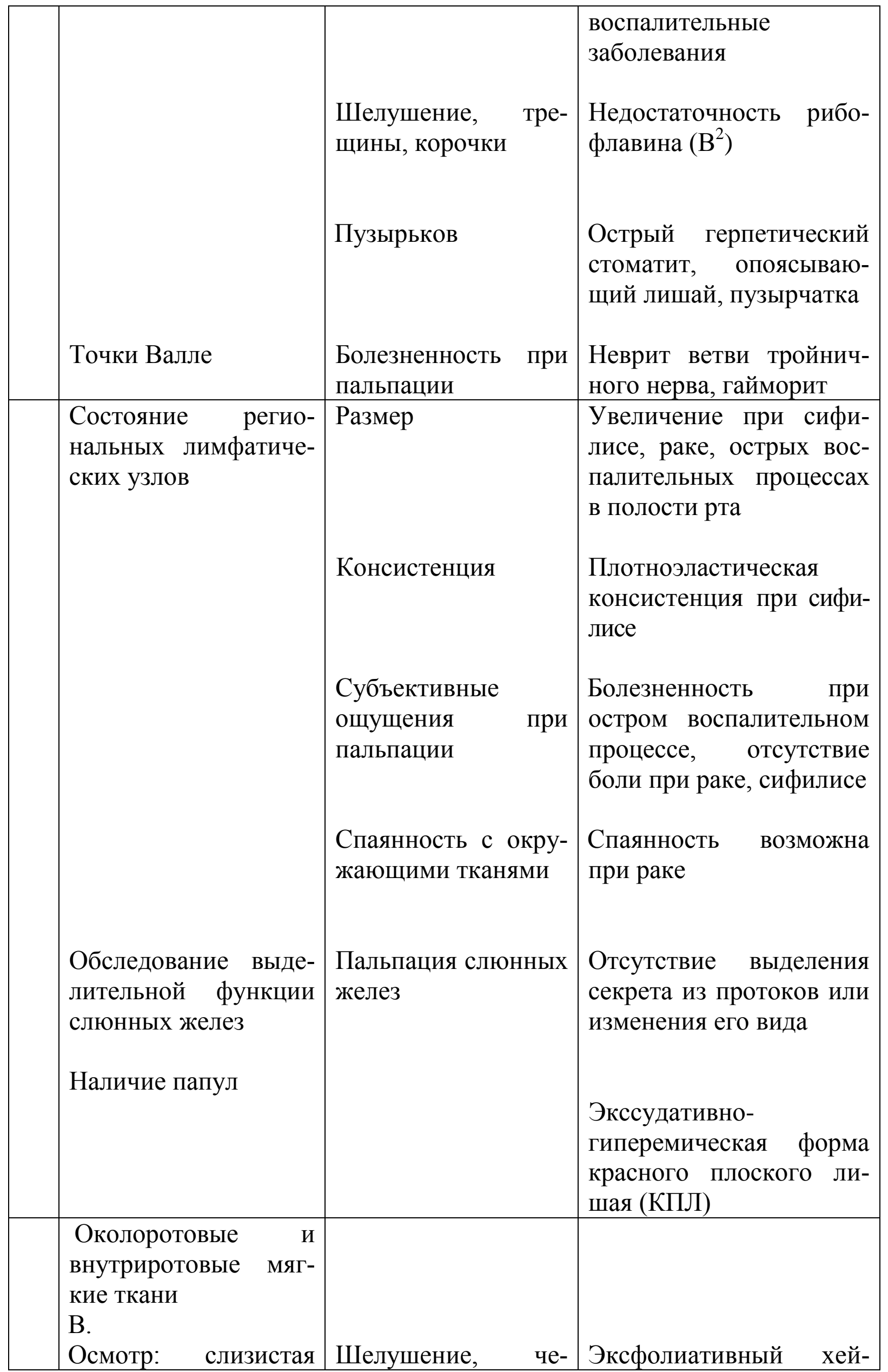




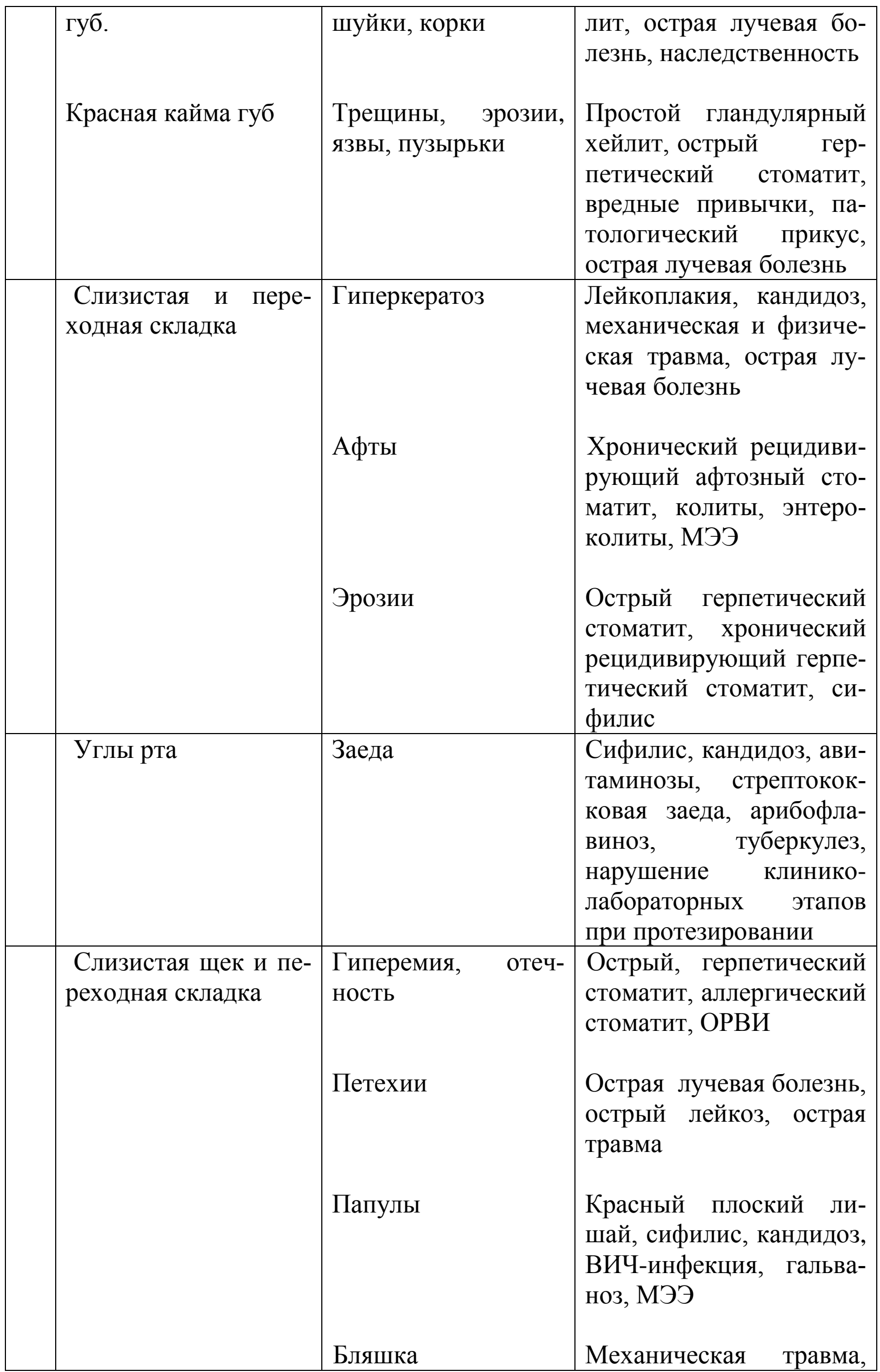




\begin{tabular}{|c|c|c|}
\hline & 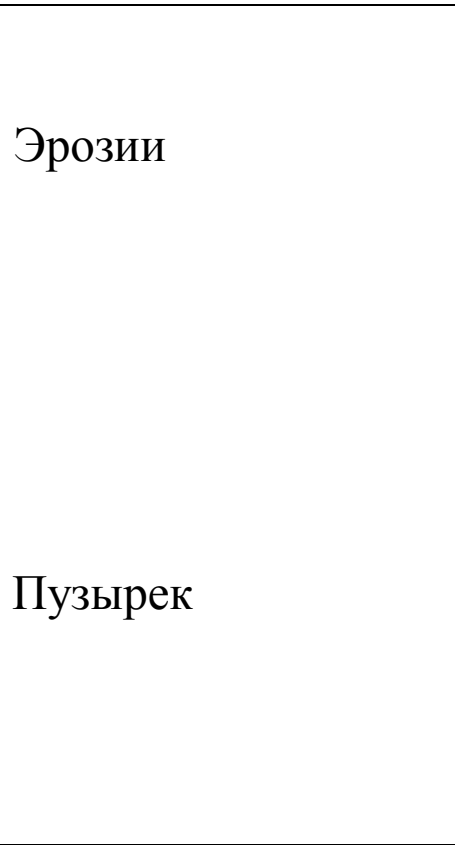 & $\begin{array}{l}\text { лейкоплакия } \\
\text { Многоформная экссуда- } \\
\text { тивная эритема, острый } \\
\text { герпетический стоматит, } \\
\text { аллергический стоматит, } \\
\text { красный плоский лишай, } \\
\text { сифилис, синдром Сти- } \\
\text { вена-Джонсона } \\
\text { Аллергические высыпа- } \\
\text { ния, острый герпетиче- } \\
\text { ский стоматит, ветряная } \\
\text { оспа, МЭЭ, КПЛ (бул- } \\
\text { лёзная форма) }\end{array}$ \\
\hline $\begin{array}{l}\text { Десна и альвеоляр- } \\
\text { ный край }\end{array}$ & 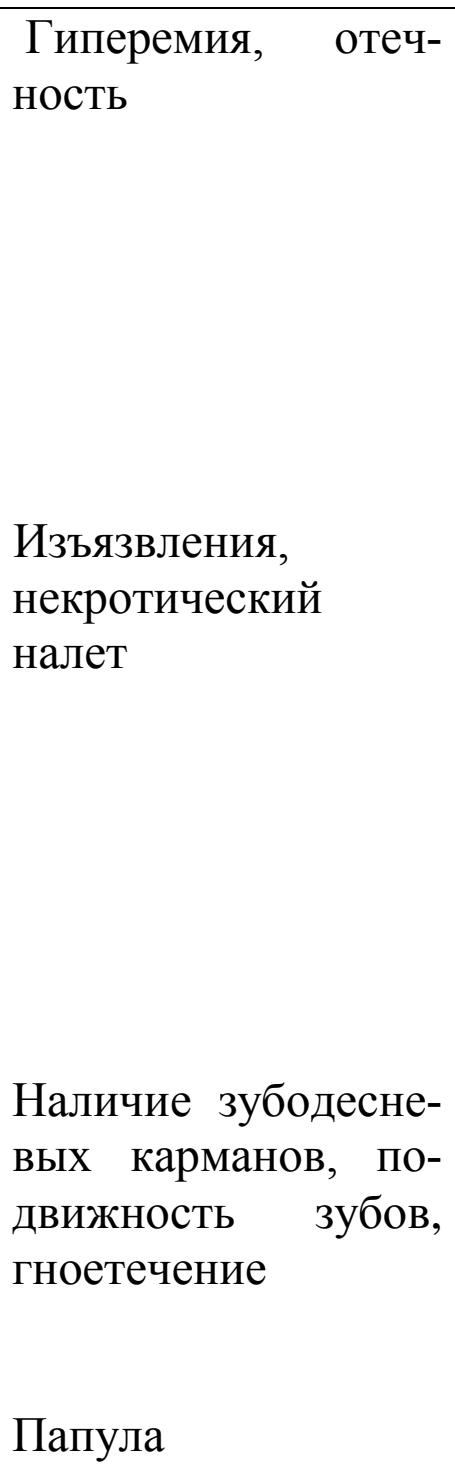 & $\begin{array}{l}\text { Гингивит, пародонтит, } \\
\text { заболевания ЖКТ, ал- } \\
\text { лергический стоматит, } \\
\text { острый герпетический } \\
\text { стоматит, острые одон- } \\
\text { тогенные заболевания } \\
\text { челюстно-лицевой обла- } \\
\text { сти } \\
\text { Язвенно-некротический } \\
\text { гингивостоматит Вен- } \\
\text { сана, сахарный диабет, } \\
\text { острый лейкоз, ВИЧ- } \\
\text { инфекция, сердечно- } \\
\text { сосудистые заболевания, } \\
\text { сифилис, съёмное про- } \\
\text { тезирование } \\
\text { Пародонтит тяжелой } \\
\text { степени, сахарньй диа- } \\
\text { бет, травматическая ок- } \\
\text { клюзия, заболевания } \\
\text { ЖКТ } \\
\text { КПЛ, кандидоз, МЭЭ }\end{array}$ \\
\hline Язык & $\begin{array}{l}\text { Слизистая языка яр- } \\
\text { ко-красного цвета, } \\
\text { сосочки языка }\end{array}$ & $\begin{array}{l}\text { Острый кандидоз, пер- } \\
\text { нициозная анемия, ал- } \\
\text { лергическая реакция на }\end{array}$ \\
\hline
\end{tabular}




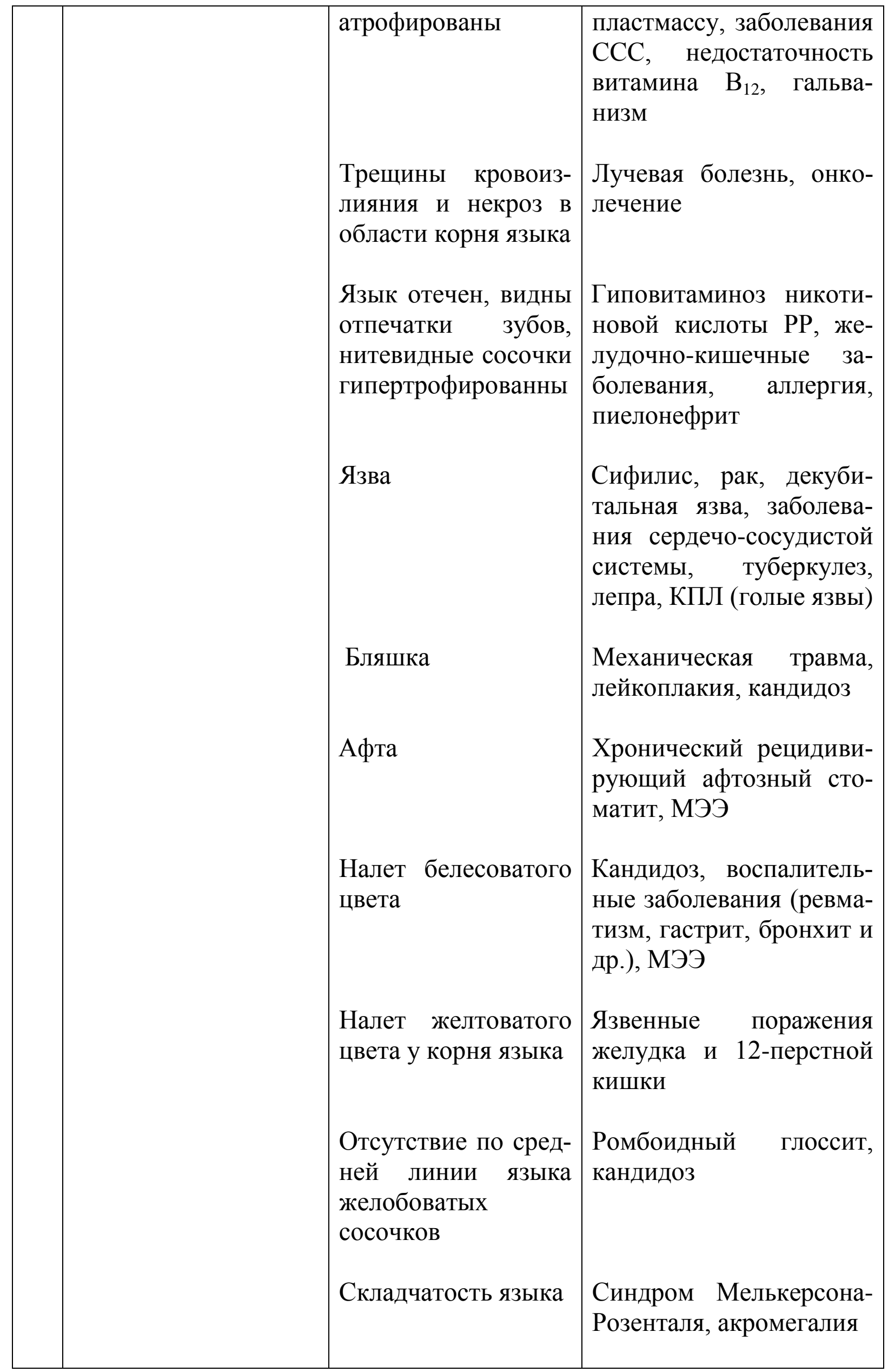




\begin{tabular}{|c|c|c|}
\hline & $\begin{array}{l}\text { Утолщение ните- } \\
\text { видных сосочков по } \\
\text { средней линии, не } \\
\text { захватывая края у } \\
\text { кончика языка } \\
\\
\text { Очаговая десквама- } \\
\text { ция языка в задней } \\
\text { его трети в виде } \\
\text { красных пятен на } \\
\text { фоне обложного } \\
\text { языка } \\
\text { Папула }\end{array}$ & $\begin{array}{l}\text { Черный волосатый язык, } \\
\text { пяпиллярно-пигментная } \\
\text { дистрофия языка, по- } \\
\text { лоскание полости рта } \\
\text { красящими лекарствен- } \\
\text { ными препаратами } \\
\text { Географический язык в } \\
\text { период обострения яз- } \\
\text { венной болезни желудка } \\
\text { и двенадцатиперстной } \\
\text { кишки } \\
\text { Сифилис, кандидоз, } \\
\text { МЭЭ, КПЛ (боковая по- } \\
\text { верхность языка) }\end{array}$ \\
\hline Дно полости рта & $\begin{array}{l}\text { Желтый оттенок } \\
\text { Участки некроза в } \\
\text { местах травмы } \\
\text { Участок гиперемии } \\
\text { и отека в проекции } \\
\text { передних резцов } \\
\text { Язва }\end{array}$ & 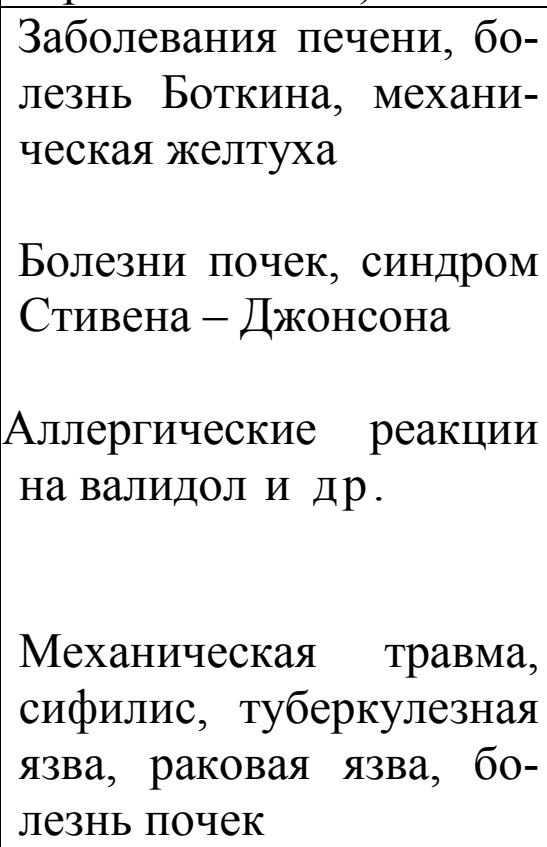 \\
\hline $\begin{array}{l}\text { Твердое и } \quad \text { мягкое } \\
\text { нёбо верхней челю- } \\
\text { сти }\end{array}$ & $\begin{array}{l}\text { Бледность } \\
\text { Темно - вишневого } \\
\text { цвета } \\
\text { Папилломатоз твёр- } \\
\text { дого неба }\end{array}$ & $\begin{array}{l}\text { Болезни печени (болезнь } \\
\text { Боткина, механическая } \\
\text { желтуха) } \\
\text { Болезни крови, авита- } \\
\text { минозы } \\
\text { Эритремия, заболевания } \\
\text { ССС } \\
\begin{array}{l}\text { Механическая травма, } \\
\text { съемное протезирование }\end{array}\end{array}$ \\
\hline
\end{tabular}




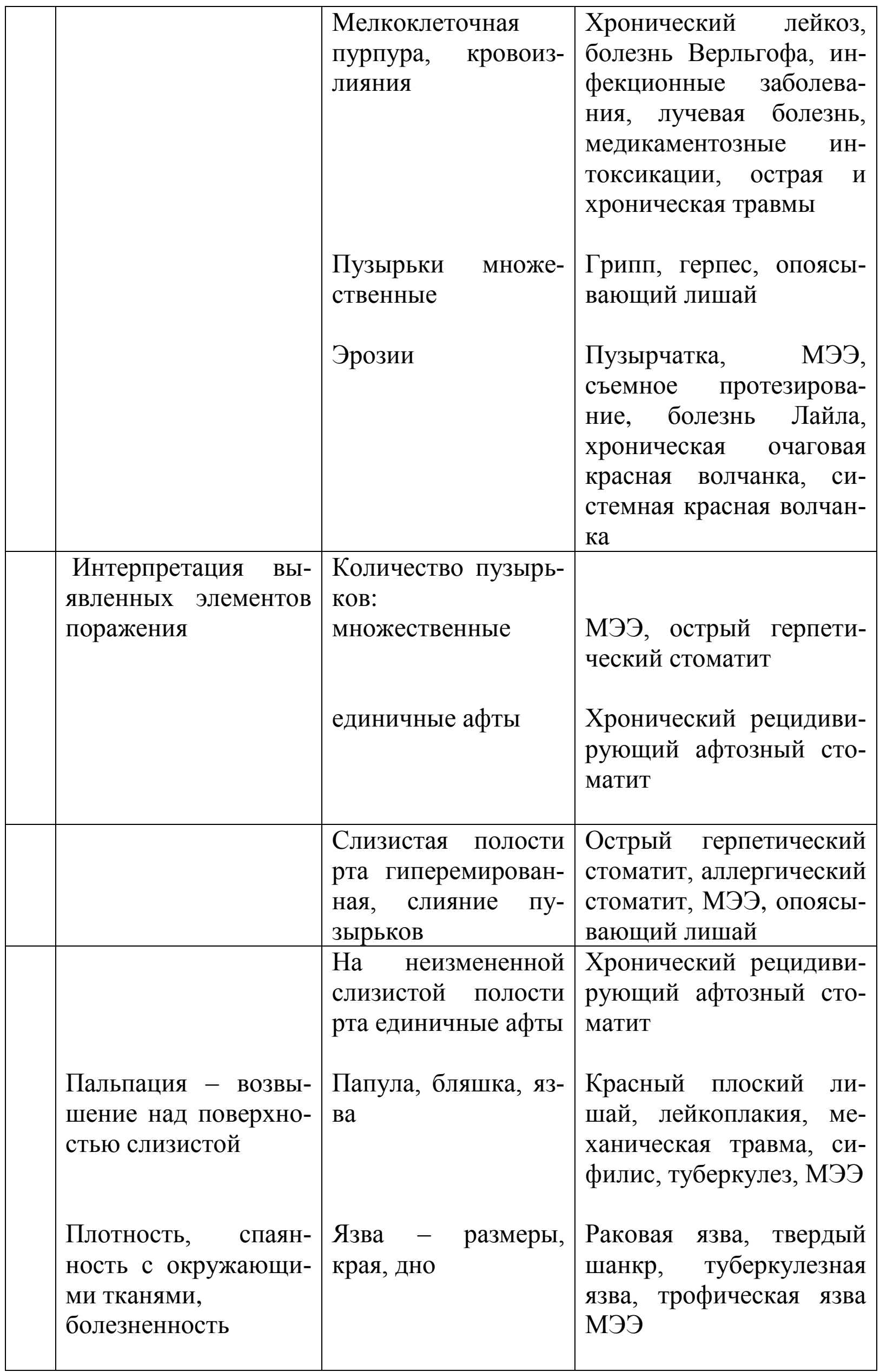




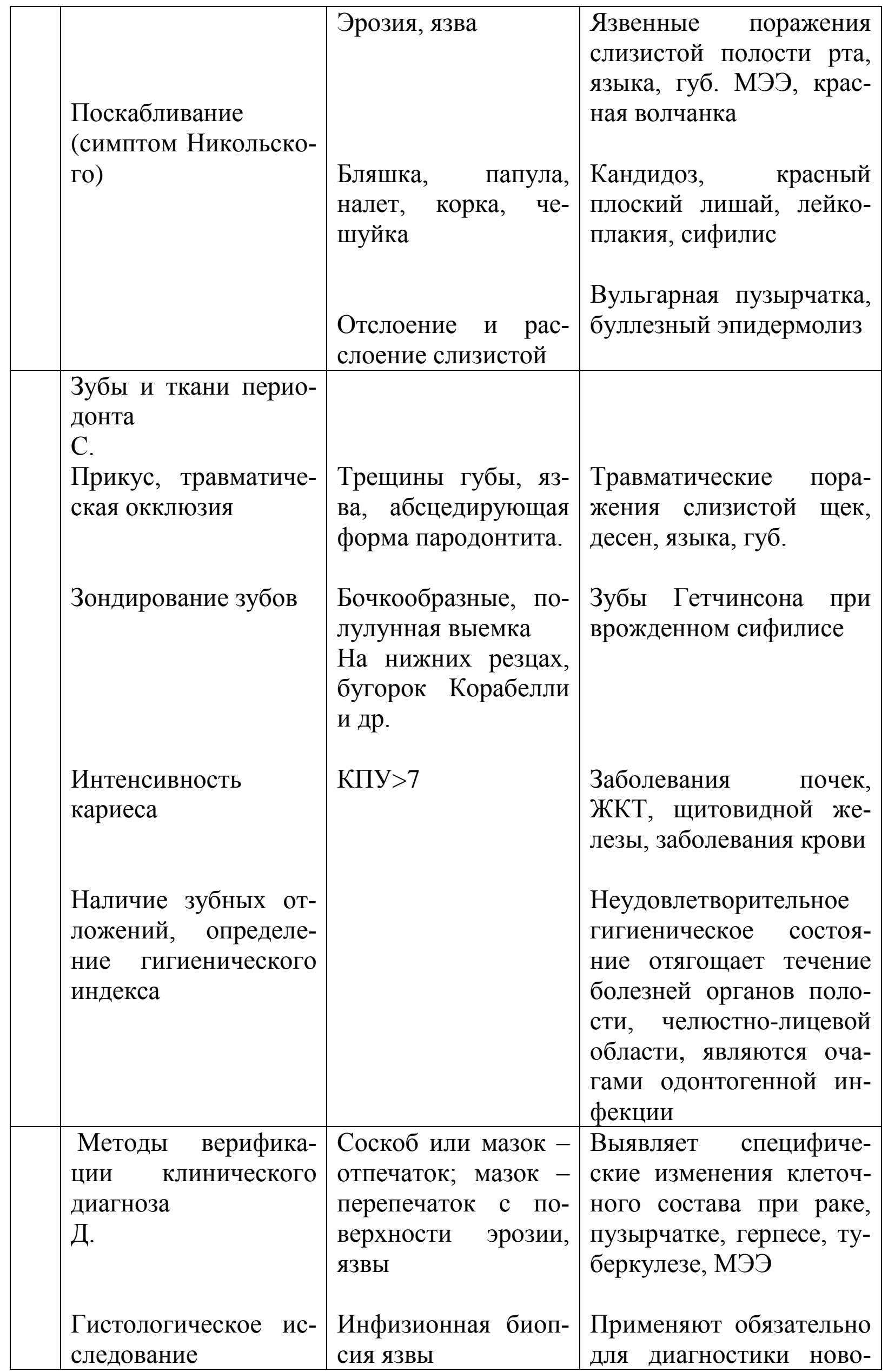




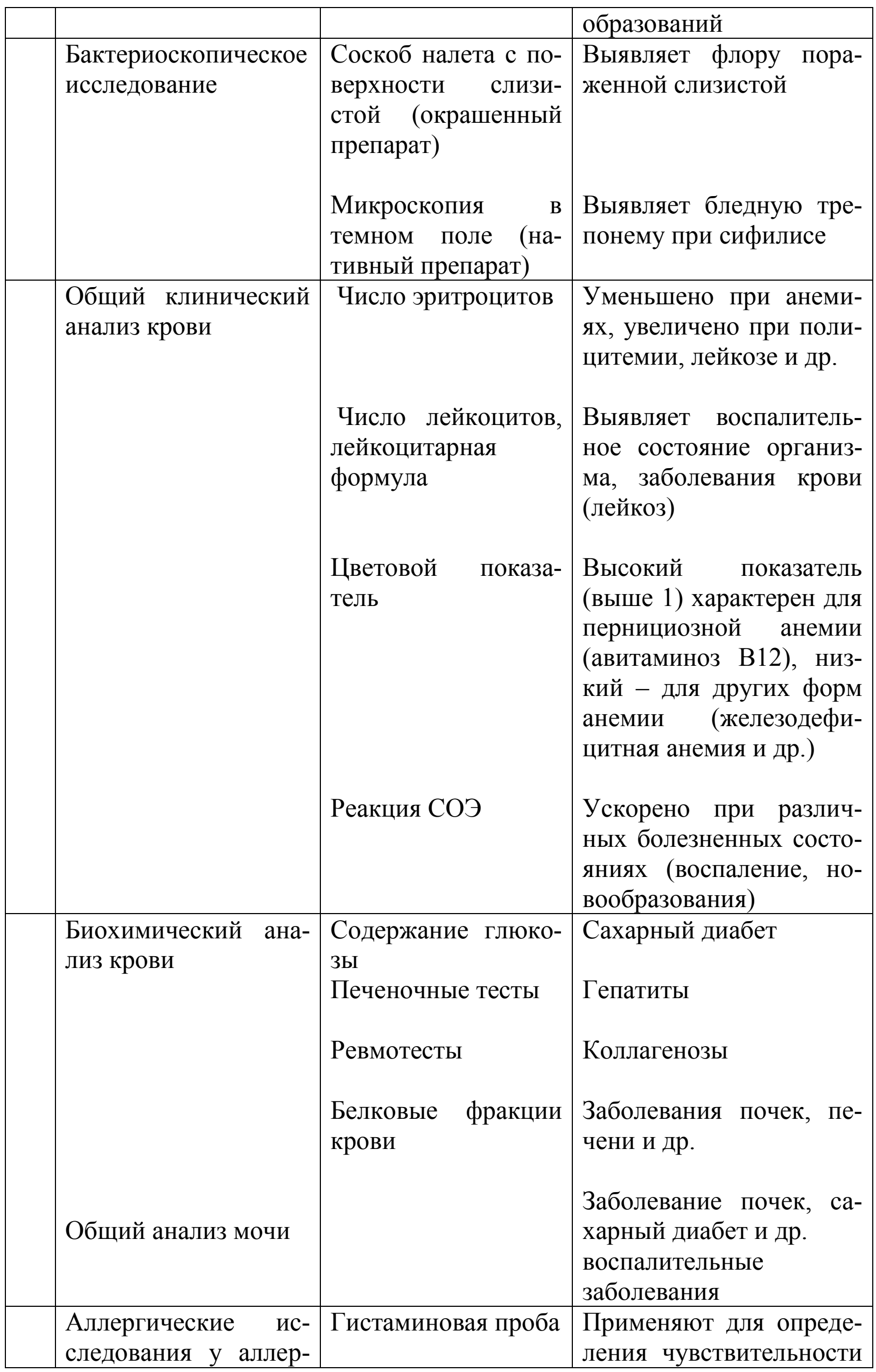




\begin{tabular}{|c|c|c|}
\hline голога & $\begin{array}{l}\text { Кожно- } \\
\text { аллергические про- } \\
\text { бы } \\
\text { Реакция торможе- } \\
\text { ния миграции лей- } \\
\text { коцитов } \\
\text { Реакция бластной } \\
\text { трансформации } \\
\text { эритроцитов } \\
\text { Реакция лейкоцито- } \\
\text { за }\end{array}$ & $\begin{array}{l}\text { к гистамину. } \\
\text { Положительная проба } \\
\text { при хроническом реци- } \\
\text { дивирующем афтозном } \\
\text { стоматите, МЭЭ. } \\
\text { Положительная реакци- } \\
\text { ия при хроническом ре- } \\
\text { цидивирующем афтоз- } \\
\text { ном стоматите и МЭЭ } \\
\text { Проводят с различными } \\
\text { аллергенами для выяв- } \\
\text { ления причинного ал- } \\
\text { лергена } \\
\text { Проводят с различными } \\
\text { аллергенами для выяв- } \\
\text { ления причинного ал- } \\
\text { лергена } \\
\text { Проводят с различными } \\
\text { аллергенами }\end{array}$ \\
\hline $\begin{array}{l}\text { Иммунологические } \\
\text { исследования }\end{array}$ & $\begin{array}{l}\text { Прямая и непрямая } \\
\text { реакции иммуно- } \\
\text { флюоресценции } \\
\text { (РИФ) } \\
\text { Определение co- } \\
\text { держания Т- - B- } \\
\text { лимфоцитов }\end{array}$ & $\begin{array}{l}\text { Используют для диффе- } \\
\text { ренциации пузырных } \\
\text { заболеваний и красной } \\
\text { волчанки } \\
\text { Применяют при аллер- } \\
\text { гических заболеваниях } \\
\text { для выявления состоя- } \\
\text { ния Т- и В-лимфоцитов }\end{array}$ \\
\hline $\begin{array}{l}\text { Серологические ис- } \\
\text { следования }\end{array}$ & $\begin{array}{l}\text { 1. Реакция Вассер- } \\
\text { мана } \\
\text { 2. ИФА } \\
\text { 3. РПГА } \\
\text { 4. Микрореакция на } \\
\text { стекле } \\
\text { 5. Реакция иммуно- } \\
\text { флюоресценции }\end{array}$ & $\begin{array}{l}\text { Изучают для диагности- } \\
\text { ки сифилиса }\end{array}$ \\
\hline $\begin{array}{l}\text { Люминесцентные ис- } \\
\text { следования }\end{array}$ & Свечения Вуда & $\begin{array}{l}\text { Используют для диагно- } \\
\text { стики красной волчанки, }\end{array}$ \\
\hline
\end{tabular}




\begin{tabular}{|c|c|c|}
\hline & & $\begin{array}{l}\text { лейкоплакии, красного } \\
\text { плоского лишая }\end{array}$ \\
\hline $\begin{array}{l}\text { Рентгенологические } \\
\text { исследования }\end{array}$ & $\begin{array}{l}\text { 1. Внутриротовая } \\
\text { рентгенография }\end{array}$ & $\begin{array}{l}\text { Выявление очагов одон- } \\
\text { тогенной инфекции у } \\
\text { больных с бактериаль- } \\
\text { ной аллергией }\end{array}$ \\
\hline & $\begin{array}{l}\text { 2. Внеротовая (об- } \\
\text { зорная рентгено- } \\
\text { грамма) } \\
\text { 3. Рентгенограмма } \\
\text { легких }\end{array}$ & $\begin{array}{l}\text { Выявление очагов одон- } \\
\text { тогенной инфекции у } \\
\text { больных с бактериаль- } \\
\text { ной аллергией } \\
\text { Травматическая, рако- } \\
\text { вая, туберкулёзная язва }\end{array}$ \\
\hline $\begin{array}{l}\text { Исследования рото- } \\
\text { вой жидкости }\end{array}$ & $\begin{array}{l}\text { 1. Визуальная оцен- } \\
\text { ка (количество, вяз- } \\
\text { кость, пенистость) } \\
\text { 2. рН - метрия } \\
\text { 3. Определение } \\
\text { гальванических то- } \\
\text { ков у лиц с ортопе- } \\
\text { дическими метал- } \\
\text { лическими кон- } \\
\text { струкциями } \\
\text { 4. Определение пе- } \\
\text { реносимости стома- } \\
\text { тологических мате- } \\
\text { риалов по методике } \\
\text { Фолля }\end{array}$ & $\begin{array}{l}\text { Аллергические заболе- } \\
\text { вания полости рта }\end{array}$ \\
\hline $\begin{array}{l}\text { Консультации у спе- } \\
\text { циалистов }\end{array}$ & $\begin{array}{l}\text { 1. Гастроэнтеролог } \\
\text { 2. Эндокринолог } \\
\text { 3. Аллерголог и др. } \\
\text { 4. Дерматовенеро- } \\
\text { лог } \\
\text { 5. Онколог } \\
\text { 6. Невролог } \\
\text { 7. Психотерапевт } \\
\text { 8. Психиатр }\end{array}$ & По показаниям \\
\hline
\end{tabular}

\section{РАЗДЕЛ ІІІ. МЕТОДЫ ОБСЛЕДОВАНИЯ ПРИ ЗАБОЛЕВАНИЯХ ЧЕЛЮСТНО-ЛИЦЕВОЙ ОБЛАСТИ}




\section{1. Субъективные методы обследования челюстно-лицевой области}

При заболеваниях челюстно-лицевой области предъявляют жалобы не только на острые боли при заболеваниях пульпы, периодонта, пародонта, но и на эстетическую неудовлетворённость, обусловленную отсутствием фронтальной группы зубов, разрушением или отломом естественной коронки передних зубов, аномалийным положением передних зубов, изменением цвета и формы имеющихся искусственных коронок (пластмассовых, комбинированных) или мостовидных протезов. На нарушение фиксации протеза, перелом базиса протеза, расцементировку искусственных коронок, штифтовых зубов или мостовидных протезов. Болевые ощущения могут быть при наличии кламмера, нарушении технологии одонтопрепарирования витального зуба без должного охлаждения или неправильно изготовления коронки.

Боль локализованного характера в слизистой оболочке обусловлена травмой при глубоком прикусе, частичном отсутствии зубов и дистальным смещением нижней челюсти, а также вторичной деформацией зубных рядов.

Жалобы на боль, жжение, покалывание, пощипывание в языке, слизистой щек и нёба могут быть проявлением аллергической реакции на некачественно изготовленные съемные и несъемные протезы (механическая травма), а также непереносимостью материала зубных протезов. Неприятные ощущения связаны нарушением теплообмена тканей протезного ложа, специфическим поражением слизистой оболочки (красный плоский лишай, лейкоплакия, глоссалгия, глоссадения, кандидоз) или проявлением общего заболевания организма (кандидоз, сахарный диабет, заболевания ЖКТ, заболевания крови, аллергические заболевания и др.).

При жалобах на «металлический вкус» в полости рта необходимо уточнить время появления (во время еды, после еды), после наложения несъемного протеза или металлической пломбы.

Анамнез настоящего заболевания. Врачу необходимо выяснить самые ранние проявления болезни, характер и особенности ее течения, вид и объем проведенного ранее лечения, результаты лечения. Необходимо выяснить самые ранние проявления болезни, особенности ее течения. Данные анамнеза врач группирует, а опрос направляет так, чтобы он давал нужные сведения для клинического обследования и способствовал постановке правильного диагноза. Во время опроса необходимо установить доверительный контакт с больным, определить его нервно-психический статус, интеллект и на этом основании проанализировать жалобы, ход развития болезни. Врач наводящими вопросами должен помочь больному изложить историю болезни, не пассивно выслушивать больного, а корректно уточнять тот или иной момент. Уточняется динамика заболевания: когда появились первые симптомы, какими они были, кто их заметил (больной, окружающие, врач), куда обращался пациент за помощью, какое лечение проводилось и с каким результатом. Следует ознакомиться с имеющейся у 
пациента документацией по поводу проведенного обследования (выписка из истории болезни, данные лабораторных и других исследований, рентгенограммы, заключения консультантов).

При жалобах на боли и припухлость в челюстно-лицевой области следует уточнить, как развивался процесс, и установить источник инфекции. При нарастании общих и местных симптомов воспалительного процесса необходима госпитализация и, возможно, проведение экстренных операций.

При наличии специфических воспалительных очагов, язв, дефектов челюстно-лицевой области и слизистой оболочки рта следует собрать сведения о наследственности, образе жизни, контактах с больными, животными и другие для исключения туберкулеза, сифилиса, сибирской язвы, ВИЧ-инфекции, а также уточнить результаты обследований, проведенных при этих заболеваниях.

При локализации процесса в области слюнных желез из анамнеза нужно выяснить, имелось ли увеличение железы, связано ли оно с приемом пищи. Следует уточнить развитие заболевания после операций на внутренних органах, особенно брюшной полости, малого таза, после вирусной или другой инфекции, а также заболеваний внутренних органов.

Независимо от характера основных жалоб необходимо выяснить удалялись ли у обследуемого зубы, когда и по каким причинам. Удаление зуба вследствие его подвижности заставляет врача выдвинуть несколько гипотез о возможных причинах. Это может быть функциональная перегрузка, пародонтит, общее заболевание организма. Необходимо определить, были ли осложнения после оперативного вмешательства, проводилось или нет непосредственное протезирование? Удаление зуба (зубов) часто является пусковым моментом в развитии заболеваний ЗЧС. В ряде случаев при расспросе больных удается установить взаимосвязь состояния ЗЧС с общим заболеванием (сахарный диабет, язвенная болезнь, ревматизм, атеросклероз, заболевание печени и др.).

Основные причины потери зубов это травма, различные воспалительные заболевания (периодонтиты, периоститы, остеомиелиты и др.), опухоли (доброкачественные, злокачественные). В некоторых случаях отсутствие зубов обусловлено задержкой их прорезывания или отсутствием зачатков. Важно также сообщение обследуемого о том, что после удаления боковых зубов появились щели между передними зубами, изменилось положение передних зубов и т.п. Это сообщение заставляет врача предположить перестройку в зубо-челюстной системе, вызванную удалением зубов. Большое значение имеет длительность нарушения целостности зубного ряда. Например, зубы (зуб) были удалены несколько лет назад, пациент не протезировался. Эти сведения позволяют врачу выяснить причину деформации зубных рядов (феномен Попова-Годдона - вертикальная, горизонтальная или сочетанная форма).

Очень важно выяснить «протезный статус» пациента. Если больной ранее пользовался протезами, необходимо уточнить: когда были изготов- 
лены протезы, как проходила адаптация, удовлетворял ли протез больного (жевание, эстетика, фонетика), не было ли неприятных ощущений (сухость, обильное слюноотделение). Врачу-стоматологу необходимо помнить, что протезирование - метод лечения, которым можно либо сохранить на долгие годы ЗЧС, либо ее разрушить. Протез любой конструкции наряду с положительным влиянием может оказывать и отрицательное воздействие на органы, ткани и среды всего организма в целом. Исследования отечественных авторов показали, что патологические изменения в зубочелюстной системе развиваются после частичной утраты зубов в 77\% случаев, а при нерациональном протезировании в 95\% случаев. Вопрос о повторном протезировании возникает при снижении лечебных, профилактических свойств и возрастающем нежелательном действии протезов. При повторном ортопедическом лечении следует уточнить, какими протезами пользовался пациент ранее (съемными или несъемными). Многие пациенты приходят на прием к врачу с убеждением в невозможности пользоваться съемными протезами. Негативный настрой часто усилен выражениями медицинского персонала о трудностях адаптации и фиксации съемных протезов. Трудности психологического характера должны быть учтены при диагностировании и составлении плана лечения. Если ранее были изготовлены протезы (съемные) и пациент ими не пользовался, то следует выяснить причины (балансировка, плохая фиксация, невозможность пережевывания пищи).

На психоэмоциональный настрой пациента влияют частые расцементировки искусственных коронок, штифтовых конструкций или мостовидных протезов, изменение цвета искусственных зубов, виниров, откол облицовочного материала, нарушение дикции, неудачно изготовленные несъемные и съёмные протезы.

При травме устанавливается время, место и обстоятельства получения травмы, ее причину (бытовая, транспортная, уличная, производственная, спортивная). Выясняют, терял ли больной сознание, и на какое время. Отмечает ли тошноту, рвоту, головокружение, кровотечение из носа, ушей, когда и кем была оказана первая медицинская помощь, в чем она заключалась, каким транспортом пострадавший был доставлен в лечебное учреждение. Время и как вводилась противостолбнячная сыворотка или столбнячный анатоксин, в каких дозировках. Следует отметить получение травмы в состоянии алкогольного опьянения.

При обращении больных с неврогенными болями необходимо собрать неврологический статус пациента. При обращении больного по поводу кровотечения, связанного с травмой, оперативным вмешательством (в том числе удалением зуба), необходимо расспросить о длительности кровотечения при ранее перенесенных операциях, порезах, ушибах. При обращении больных по поводу болей и нарушения функции височнонижнечелюстного сустава необходимо выяснить связь процесса с заболеваниями сердечно-сосудистой системы, опорно-двигательного аппарата и др. 
При опухолях и опухолеподобных поражениях лица, челюстей, органов полости рта необходимо выяснить связь процесса с другими заболеваниями внутренних органов, ЛОР-органов, кожи и др., необходимо уточнить особенности роста новообразования (распространенный или ограниченный), сопровождающие симптомы (боли и их характер, нарушение функции и др.).

Врожденные дефекты и деформации требуют выяснения данных семейного анамнеза (наследственность), характер течения первой половины беременности (особенно второй и третий месяц внутриутробного развития плода) и родов, особенности развития в детском возрасте и позже. При приобретенных дефектах и деформациях уточняют причину их возникновения (травматические повреждения, неспецифические и специфические воспалительные процессы, ожог, опухолевые заболевания - уточнить особенности роста новообразования (распространенный или ограниченный), сопровождающие симптомы (боли и их характер, нарушение функции и др.)).

При приобретенных дефектах и деформациях необходимо исключить такие заболевания, как сифилис, хронический остеомиелит челюсти, актиномикоз, нома.

Необходимо уточнить наличие у больного иммунопатологических заболеваний и состояний. Выявление первичных или вторичных иммунодефицитных состояний и сопутствующих им заболеваний позволит правильно оценить функциональное состояние организма, уточнить диагноз.

Во время расспроса больного врач должен выяснить причины возникновения боли, момент появления, ее характер и интенсивность, в связи с чем она уменьшается или увеличивается.

Анамнез жизни посвящается физическому, психическому и социальному развитию пациента. Необходимо выяснить у пациента:

1. Место рождения и жизни.

2. Условия жизни больного, питания (характер принимаемой пищи, регулярность приема пищи).

3.Наличие трудовой деятельности, условия труда, производственные вредности (их характер).

4. Перенесенные и сопутствующие заболевания, какие заболевания перенес, начиная с детского возраста (в хронологической последовательности), наличие у родителей и родственников таких заболеваний, как туберкулёз, сифилис, алкоголизм, психические заболевания, злокачественные новообразования, заболевания пародонта, кариес.

5. Непереносимость лекарственных веществ.

6. Вредные привычки: курение, употребление алкоголя, наркотиков (с каких лет, количество).

7. Гигиена полости рта.

8. Мотивация больного к поддержанию и сохранению своего здоровья. 
Место рождения и жизни. Большое значение имеют знания природных условий: географическое расположение, высота проживания, солнечная радиация, влажность воздуха. Нарушения состава и качества воды (наличие микроэлементов, жёсткость воды, РН воды и т.д.), могут привести к кариозным и некариозным поражениям твёрдых тканей зуба. При избытке фтора в питьевой воде возникает очаг эндемического зоба, при котором даже при лёгкой степени флюороза отсутствует истирание эмалевых бугров, что в последующем приводит к травматическому повреждению пародонта за счёт супраконтактов.

Диспепсические расстройства в период кальцификации зубов могут быть причиной клиновидных дефектов или патологической стираемости в сформированной зубочелюстной системе. Нарушения в режиме питания в период развития и роста челюстей (например, искусственное вскармливание, постоянный приём мягкой протёртой пищи в период молочного и сменного прикуса) способствуют развитию зубочелюстных аномалий. Определённую роль в возникновении ряда заболеваний (очаговый пародонтит, гингивит, отложение зубного камня) играет характер разжёвывания пищи. На стороне привычного жевания (фиксированный функциональный центр разжёвывания) может развиться очаговый пародонтит, на противоположной стороне - зубные отложения.

Профессия может обусловить развитие той или иной патологии. Работа в кислотных цехах, угольных шахтах и в мукомольной промышленности приводит к стираемости зубов, а у работников акрилового производства отмечается непереносимость протезов из акриловых материалов в виде дерматозов. У работников кондитерских предприятий наблюдается множественный кариес острого течения. На кирпичных заводах, на предприятиях, где выделяются фтористые соединения и у сварщиков могут наблюдаться на слизистой полости рта некротические поражения.

Кислотный некроз эмали встречается у работников химической промышленности. Это позволяет получить правильное представление о физическом и нравственном здоровье. Следует выяснить, какие заболевания перенес больной, как они протекали, какое проводилось лечение и его результаты. При сборе анамнеза необходимо обратить внимание на сопутствующие заболевания. Иногда при расспросе удается установить, что ухудшение состояния зубочелюстной системы наступило в период обострения заболеваний желудочно-кишечного тракта или после гриппа.

При наличии специфических воспалительных очагов, язв, дефектов челюстно-лицевой области и слизистой оболочки полости рта следует собрать сведения о наследственности, образе жизни, контактах с больными, животными и другие для исключения туберкулеза, сифилиса, сибирской язвы, ВИЧ-инфекции, а также уточнить результаты обследований, проведенных при этих заболеваниях. Врач должен выяснить общесоматический статус пациента. Например, бронхиальная астма является противопоказанием к применению оттискных материалов, имеющих запах. У этих больных нельзя проводить перебазировку протезов в полости рта (в данном 
случае перебазировка производится лабораторным методом). Проводя опрос, врач должен направить разговор в нужном направлении. Во время беседы пациенты стараются фиксировать внимание врача на моменты, которые с их точки зрения являются главными, но не являются главными с точки зрения врача. От умения врача установить контакт с больным, создать обстановку заинтересованной беседы, правильно задавать вопросы во многом зависит и качество получаемой информации. Опрос больного это классический метод обследования больного, важность которого не уменьшилась и в настоящее время. Сбор анамнеза требует от врача многих знаний как специальных, так и психологических, и хорошего навыка.

В кабинете врача диагноз устанавливается по данным анамнеза приблизительно в 50\% случаев, о чём свидетельствовали корифеи отечественной медицины: М.Я. Мудров, С.П. Боткин, А.А. Остроумов, на основании объективного обследования - 30\%, по методам верификации клинического диагноза - 20\% случаев. Анамнез должен быть не только правильно собран, но и грамотно проанализирован с учётом личности больного. Достоверность данных анамнеза оценивается при сопоставлении их физикальными, инструментальными и лабораторными показателями.

\section{2. Объективные методы обследования челюстно-лицевой области. Рекомендации ВОЗ. Внеротовая область}

Обследование больного начинают с общего осмотра и определения его состояния (удовлетворительное, средней степени тяжести, тяжелое и крайне тяжелое).

Обследование челюстно-лицевой области включает внешний осмотр, антропометрические измерения, пальпацию, перкуссию, осмотр полости рта, инструментальное исследование (зондами, тупыми и острыми иглами и др.). Проводится оценка состояния органов и слизистой оболочки полости рта, зубов, зубных рядов, пародонта, оценку несъемных и съемных конструкций протезов, исследование диагностических моделей, а также методы верификации (анализ крови, мочи, слюны, биоптатов и мазков, аллергологические тесты), функциональные и рентгенологические исследования.

Клиническое обследование при необходимости может быть дополнено взятием соскоба, проведением пункции или биопсии, биохимическими, микробиологическими, иммунологическими исследованиями, томографией и др.

По рекомендации ВОЗ объективное обследование проводят в следующей последовательности:

\section{Внеротовая область.}

Внешний осмотр начинается во время сбора анамнеза, незаметно для больного. При этом врач решает вопросы эстетического оптимума: эмоциональное состояние, цвет кожи лица: возможен цианоз (синюшность кожных покровов). Различают периферический цианоз и центральный. Пери- 
ферический цианоз развивается при замедлении кровообращения и наблюдаются холодные конечности . Центральный цианоз проявляется равномерной синюшностью всего тела, конечности - теплые. Нарастающий цианоз любого происхождения имеет неблагоприятный прогноз. Бледность кожи может быть временной или постоянной.

Внезапная бледность может наблюдаться при резком уменьшении количества крови в сосудах кожи и скоплении ее в сосудах брюшной полости (обморок, коллапс). Бледность может развиться при кровотечениях, анемиях. Красная, влажная кожа свойственна анафилактическому шоку. Клиническое значение имеет кровоизлияние в кожу. Обширные кровоподтеки свидетельствуют о нарушении свертываемости крови. Мелкие петехии возникают преимущественно при поражении сосудистой стенки. Появление геморрагии при любом заболевании свидетельствует о его тяжести, увеличивающейся интоксикации.

Отеки являются важным признаком многих заболеваний. В частности, при поражении почек лицо отечное, бледное. При наличии митрального порока - лицо цианотичное, губы синюшные. Длительно существующие отеки плотные, сопровождаются цианозом. Почечные отеки мягкие при пальпации, явления цианоза не наблюдается.

Во время обследования определяют тип дыхания (ротовое, носовое), симметричность лица, его рельефа, обусловленного соединением костей лицевого скелета, уровнем развития подкожного жирового слоя. Важно определить состояние хрящевого отдела носа, глазных и ротовой щелей, ушных раковин и кожным покрытием, форму лица (квадратное, овальное, коническое). Во время опроса обращают внимание на:

состояние кожных покровов лица (цвет, тургор, сыпь, рубцы и т.д.);

выраженность подбородочной и носогубной складок (сглажены, умеренно выражены, углублены);

положение углов рта (приподняты, опущены);

линию смыкания губ (наличие заеды);

степень обнажения передних зубов или альвеолярной части при разговоре и улыбке;

положение подбородка (прямое, выступает, западает, смещен в сторону);

симметричность половин лица;

высоту нижней части лица (пропорциональная, увеличена, уменьшена).

Визуальной и метрической оценкой лица при различных по динамическим состояниям выявляют признаки гармоничного развития лица:

три его части (верхняя, средняя и нижняя) по высоте примерно равны;

носогубный угол колеблется в пределах $90-100^{\circ}$;

угол выпуклости лица составляет $160-170^{\circ}$;

сагиттальный наклон верхних передних зубов в пределах 90-100; 
трансверзальный наклон верхних передних зубов варьирует от 5 до $10^{\circ}$, а этот же показатель для одноименных нижних зубов равен $0^{\circ}$;

углы изгиба верхнего зубного ряда, верхней губы и горизонтальной профилировки глазных щелей одинаковы и колеблются в пределах $170^{\circ}$;

ширина фильтра равна ширине двух верхних центральных резцов;

межглазничная ширина равна ширине (длине) одного глаза, а оба эти параметра идентичны ширине верхних резцов:

высота уха равна высоте каждой трети лица, а в сагиттальной плоскости гармонирует с профилем носа.

Конфигурация лица может быть изменена вследствие смещения нижней челюсти кзади, в сторону или западения в скуловой области, удлинения среднего отдела лица, западения спинки носа и других нарушений, обусловленных травмой.

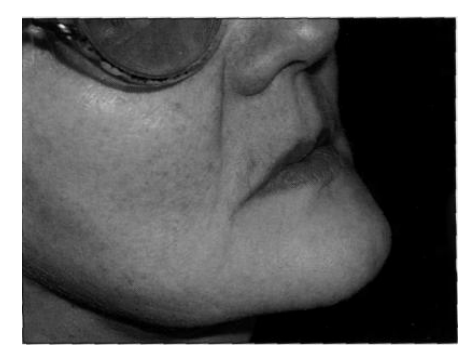

Рис. 25. К. Ронкин. Снижение высоты нижнего отдела лица.

Обращают внимание также на ушибы, ссадины, раны, гематомы.

Лицо в норме чаще бывает асимметрично. При наличии асимметрии лица и шеи определяется: отек, размеры отека, гиперемия, синюшность отека, его локализация. Определяется также наличие инфильтрата, опухолевидного образования, деформации, рубцов. Асимметрия, связанная со смещением нижней челюсти в «привычную» окклюзию, недоразвитием или гиперплазией ветви нижней челюсти (подбородок смещается в ту сторону, где ветвь короче).Также связанная с аномалией прикуса, анкилозом, микрогенией, деформирующим артрозом, гипертрофией жевательных мышц, изменение высоты нижнего отдела лица (рис.26)

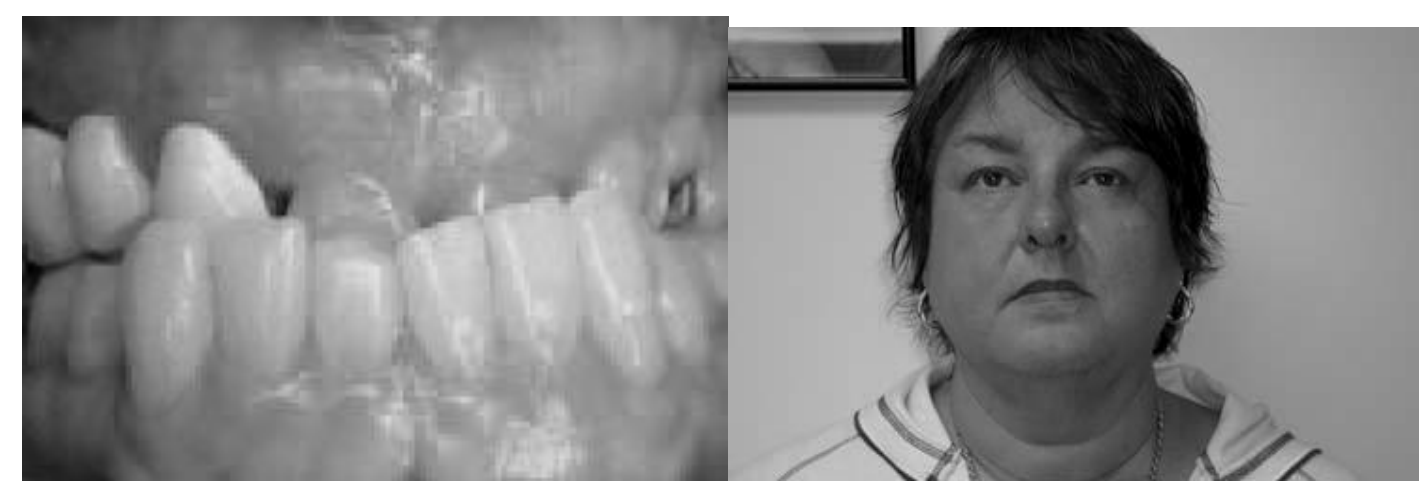


Рис. 26. К. Ронкин. Двусторонняя дисфункция ВНЧС в сочетании с нейромышечной дисфункцией жевательных мышц. Мезиальный прикус, деформация окклюзионной плоскости верхнего нижнего зубных рядов.

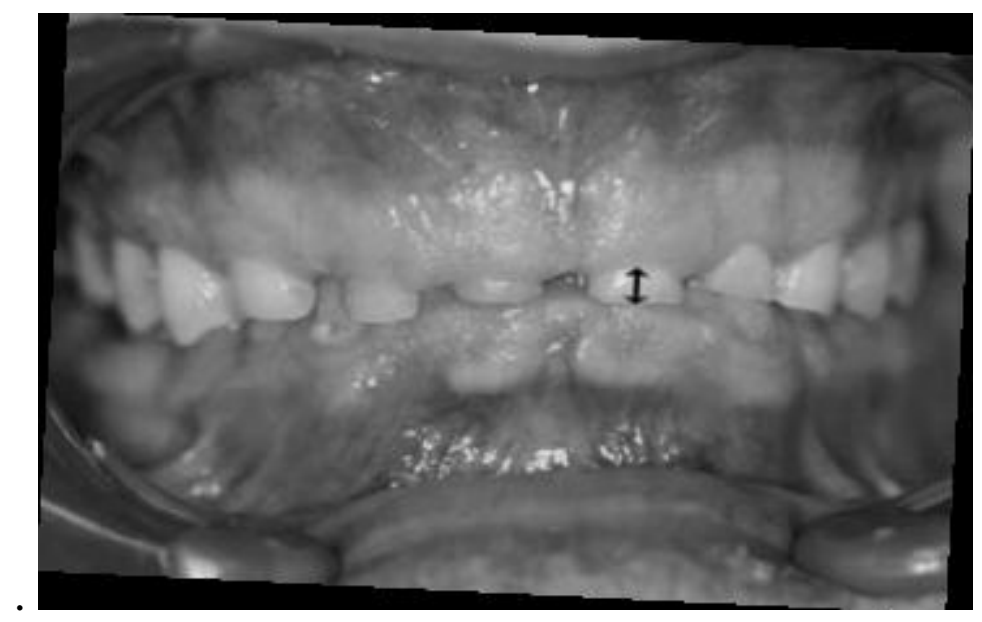

Рис. 27. (К. Ронкин). Изменение положения нижней челюсти в результате патологической стираемости. Снижение высоты нижнего отдела лица

Шелушение на коже лица, на красной кайме губ, наличие морфологических элементов наблюдаются при авитаминозах, инфекционных заболеваниях, дерматозах, аллергических заболеваниях. При определении количества и консистенции слюны обращают внимание на заболевания ЖКТ, болезни слюнных желёз, синдром Шегрена.

При увеличении межальвеолярной высоты отмечается стук зубов во время разговора или еды. При понижении высоты нижнего отдела лица верхняя губа укорачивается, носогубные складки становятся более глубокими, опускаются углы рта и кончик носа. Западение щек свидетельствует о значительной или полной потере зубов (рис28)

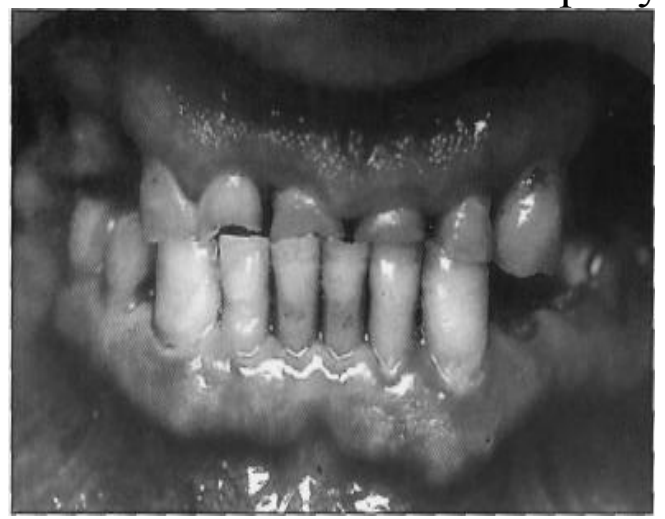

Рис. 28. Частичное отсутствие зубов на обеих челюстях. Повышенное стирание твёрдых тканей зубов (горизонтальная форма). Снижение высоты нижнего отдела лица на 5 мм.

При парезе лицевого нерва, дисфункциональном состояниии ВНЧС, острых одонтогенных воспалительных заболеваниях носогубная складка сглажена.

Пальпация точек Валле проводится для проведения дифференциального диагноза (невралгия тройничного нерва, синусит). Состояние ВНЧС - 
определяют диапазон его движений, наличие возможных отклонений, мышечное напряжение. Наличие парафункций, бруксизм.

Необходимо провести наклоны, повороты, запрокидывание головы, чтобы определить ее движения.

При внешнем осмотре обращают внимание на характер движения нижней челюсти (плавный, рывкообразный, смещение вправо, влево), степень открывания рта (полное, неполное), наличие сужения ротовой щели, хруста и щелканья в ВНЧС. Определяют наличие ограниченного раскрывания рта и небольшое отклонение нижней челюсти в сторону поражённого сустава при опускании (рис.29).

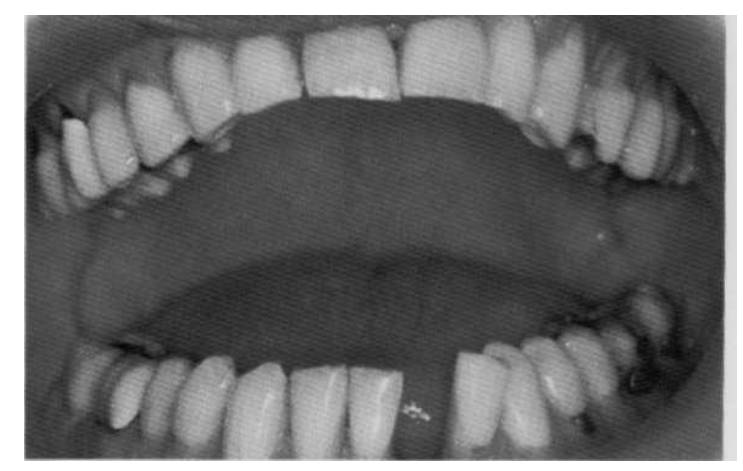

Рис. 29. Х. Смуклер.

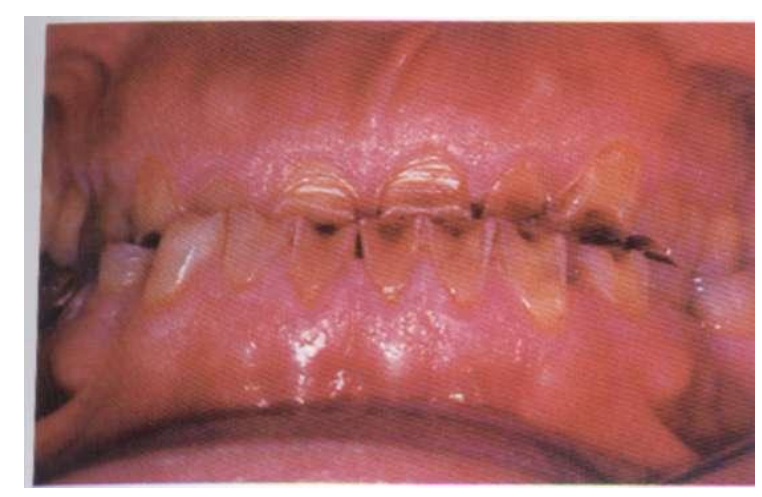

Рис. 30. Х. Смуклер. Химическая эрозия зубов (частое употребление лимонов). Снижение высоты нижнего отдела лица

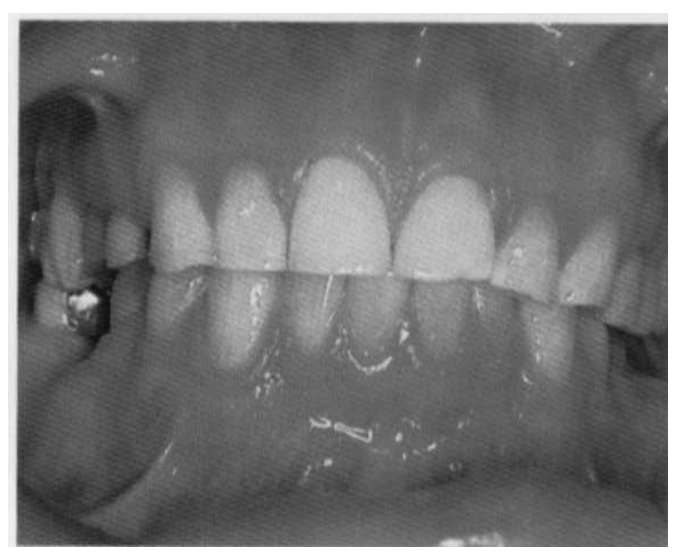


Рис. 31. Х. Смуклер. Патологическая стираемость в результате ночной парафункциональной активности. Снижение высоты нижнего отдела лица

Хватова В.А. в работе «Функциональная окклюзия в норме и патологии» (1993 год) предлагает для определения идеальной окклюзии следующие признаки:

интактная зубочелюстная система;

в центральной окклюзии одновременный двусторонний контакт опорных бугров всех боковых зубов с краевыми ямками и выступами двух соседних зубов противоположной челюсти. За исключением задне-щечных бугров нижних моляров и передненебных бугров верхних моляров, находящихся в контакте с центральными фиссурами своих антагонистов. Легкий контакт передних зубов;

интактный пародонт, отсутствие патологической подвижности зубов, направление функциональной нагрузки вдоль оси зуба;

стертость твердых тканей зубов, соответствующая возрасту и не превышающая $1 / 3$ коронковой части зуба (физиологическая стертость);

совпадение центральной окклюзии с центральным соотношением челюстей или расположение кпереди от него на 1-2 мм по срединносагиттальной линии;

двусторонний первоначальный контакт скатов бугров жевательных зубов в положении центрального соотношения челюстей и последующее «скольжение по центру» в центральную окклюзию без бокового смещения нижней челюсти;

в передней окклюзии разобщение боковых зубов;

в боковой окклюзии на рабочих сторонах контакт клыков или наряду с клыками в контакте щечные бугры премоляров и моляров. Остальные зубы разобщены;

при физиологическом покое нижней челюсти расстояние между зубами 2-4 мм;

отсутствие парафункциональной активности мышц (скрип, сжатие зубов), стабильность фазной ЭМГ-активности мышц во время функции жевания;

двусторонний тип жевания, симметричные контакты в боковых окклюзиях;

центрическое симметричное положение головок ВНЧС в ямках в центральной окклюзии, симметричная амплитуда движения суставных головок при открывании рта (головки не выходят за пределы вершин суставных бугорков);

отсутствие боли жевательных мышц, ВНЧС и суставного шума; смещение нижней челюсти при открывании рта по средней линии без боковых отклонений и зигзагообразных сдвигов;

амплитуда открывания рта 40-50 мм, боковых движений - 7 мм; 
ощущение "отсутствия окклюзии";

отсутствие жалоб на эстетические и фонетические нарушения.

Одновременно все признаки идеальной окклюзии редко встречаются. У взрослых обычно имеются те или иные морфологические отклонения со стороны вида смыкания, строения зубных рядов, положения отдельных зубов в зубной дуге и др.

В положении идеальной окклюзии мышцы находятся в наиболее сбалансированном состоянии. Это означает, что в мышцах эффективно происходят процессы оксигенации и детоксикации.

Хорошо отдохнувшие мышцы, не содержащие токсинов, эффективно осуществляют свою функцию. Мышцы в гипертонусе накапливают значительное количество токсинов, не успевают реоксигенировать и, как результат, могут быть источником болевых ощущений.

Нервно-мышечная система основывается на том, что нижняя челюсть должна иметь комфортное положение физиологического покоя, когда все мышцы, участвующие в перемещении нижней челюсти, находятся в расслабленном и сбалансированном состоянии. Из такого положения физиологического покоя нижняя челюсть имеет возможность беспрепятственного перемещения по правильной траектории движения в положение максимального бугорково-фиссурного контакта верхних и нижних зубов, обеспечивая правильную окклюзию. При этом резцовые контакты верхних и нижних зубов не должны удерживать нижнюю челюсть в наиболее заднем положении, центральные контакты в боковых участках должны быть точечными и не иметь преждевременных контактов на наклонных плоскостях бугров.

В этом случае зубочелюстная система будет работать нормально. Жевательная нагрузка будет распределяться равномерно вдоль продольных осей всех жевательных зубов.

Если функция жевания не нарушена, отсутствуют жалобы на патологические состояния органов зубочелюстно-лицевой системы, что свидетельствует об адаптации больного к этим отклонениям, то окклюзию можно рассматривать как приемлемую и не проводить ее коррекцию.

Оправдано устранение аномалий прикуса, преждевременной потери зубов (особенно постоянных моляров) у детей и подростков, так как в дальнейшем в результате дополнительной потери зубов, их разрушения могут произойти тяжелые деформации зубных рядов.

Различные симптомы дисфункции могут быть у лиц с нормальной окклюзией, и в этих случаях нужно думать о неокклюзионных парафункциях, обусловленных, например, психосоматическими заболеваниями; о структурных изменениях ВНЧС, не связанных с окклюзией (например, о ревматоидном артрите).

После осмотра исследуют пульс. Частота пульса у взрослого колеблется в пределах 60-85 уд/мин.

Внешний осмотр заканчивается пальпацией патологически измененных тканей, подчелюстных и подбородочных лимфатических узлов. 
После осмотра приступают к пальпации. Пальпация - метод диагностического исследования путем ощупывания определенной части тела. При пальпации мягких тканей определяется консистенция припухлости (мягкая, плотная), болезненность, зона распространения, подвижность, спаянность с окружающими тканями (собирается кожа в складку над припухлостью или нет), наличие участков размягчения и флюктуации (симптом нахождения жидкости в замкнутой полости). Истинная флюктуация определяется в двух взаимно-перпендикулярных направлениях. Флюктуация, ощущаемая только в одном направлении, является ложной (при опухолях мягких тканей — липоме).

Пальпируются все неровности, утолщения костной ткани, определяется их симметричность, болезненность, уточняются размеры. Следует обратить внимание на состояние регионарных лимфатических узлов. Пальпация лимфатических узлов позволяет установить их величину, консистенцию, болезненность. При острых воспалительных процессах лимфатические узлы быстро увеличиваются в размерах, резко болезненные, ограничение их подвижности, может наблюдаться флюктуация. При хронических воспалительных заболеваниях лимфоузлы медленно увеличиваются, слегка болезненные, подвижность сохраняется.

При пальпации поднижнечелюстных, задних ушных и шейных лимфоузлов врач одной рукой наклоняет голову больного вниз, другой рукой последовательно ощупывает их тремя пальцами. Подподбородочные лимфоузлы пальпируются в таком же положении указательным пальцем. Щечные, носогубные, нижнечелюстные (супрамандибулярные) лимфоузлы пальпируются бимануально - пальцами одной руки со стороны полости рта, другой - снаружи. Околоушные лимфатические узлы пальпируются двумя-тремя пальцами в проекции ветви нижней челюсти или позадичелюстной области, а также бимануально - по переднему краю околоушных желез. Врач становится позади больного, пальпирует надключичные лимфатические узлы тремя пальцами, помещенными на ключице. которые расположены в большой и малой надключичных ямках.

Пальпация позволяет уточнить границы патологических изменений, консистенцию тканей, способность кожи собираться в складку, наличие рубцов, свищевых ходов. При наличии припухлости околочелюстных мягких тканей определяют ее консистенцию, спаянность кожи с подлежащими тканями, ее цвет. Если тупой конец инструментов при давлении оставляет след, то это указывает на отек воспалительной природы. Он может иметь место при различных воспалительных заболеваниях и травме лица и челюстей. При абсцессе, флегмоне, лимфадените и других воспалительных заболеваниях в околочелюстных мягких тканях определяется уплотнение околочелюстных мягких тканей, болезненность. При пальпации с трудом собирается в складку или не образует ее. Цвет изменен от розового до ярко-красного или багрово-синего, температура тканей повышена. Необходимо отмечать границы патологических изменений, определять участки 
наибольшей болезненности и флюктуации, спаянность пораженных тканей с подлежащими костями лицевого скелета, наличие свищей.

Следует обращать внимание на нетипичные неровности кости, болевые ощущения при пальпации. Сравнительное пальпаторное исследование костей лицевого скелета проводят по костным контурам лица и главным образом в местах соединения костей, обращая внимание на нетипичные неровности кости, болевые ощущения при пальпации. При переломе челюстей, скуловой кости нарушается функция открывания рта в виде ограничения, смещения нижней челюсти в сторону и др.

Пальпаторно исследуют височно-нижнечелюстной сустав - головку мыщелкового отростка, сочленения ее с суставной впадиной, определяют объем движений нижней челюсти при открывании и закрывании рта, в стороны. Пальпацией определяют чувствительность выхода периферических ветвей тройничного нерва в точках Балле (надглазничного, подглазничного и подбородочного нервов). Различные заболевания и повреждения нервов лица и челюстей сопровождаются болями, нарушениями чувствительности. При пальпаторном исследовании боли могут усиливаться или может развиться приступ. При обследовании отмечается также нарушение чувствительности кожи лица (анестезия, парестезия, гипестезии, гиперестезии).

При подозрении на онкологические заболевания применяют глубокую пальпацию. Опухоли и опухолеподобные заболевания могут иметь различную консистенцию: тестоватую, плотноэластическую, хрящеватую и др., гладкую или бугристую поверхность, четкие или плохо определяемые границы. Значение имеет пальпация регионарных лимфатических узлов - поднижнечелюстных, подбородочных и других шейных, подбородочных, лицевых и пр. Для пальпации поднижнечелюстных узлов врач правой рукой наклоняет голову больного вниз, а левой последовательно ощупывает их тремя пальцами, наклоняя голову больного в соответствующую сторону. Подбородочные лимфатические узлы ощупывает в таком же положении указательным пальцем, а сосцевидные - II пальцем, двигая его вперед к заднему краю ветви нижней челюсти и кзади - к переднему краю грудино-ключично-сосцевидной мышцы.

Околоушные лимфатические узлы пальпируются в проекции поверхности ветви нижней челюсти, в позадичелюстной области - в толще слюнной железы и бимануально - по переднему краю околоушной слюнной железы. Латеральные шейные лимфатические узлы пальпируют 2-3 пальцами кпереди и кзади от грудино-ключично-сосцевидной мышцы, от сосцевидного отростка книзу к ключице. Далее, став позади больного, тремя пальцами (II, 11I, IV), помещенными на ключице, ощупывают надключичные лимфатические узлы.

Для дифференциальной диагностики хронических лимфаденитов челюстно-лицевой области и шеи с внеорганными доброкачественными и первичными злокачественными опухолями этой области, с метастазами опухолей в регионарные лимфатические узлы, с лимфомами, с врождён- 
ными новообразованиями применяется морфологическая верификация. В.А. Коробкиным разработана методика тонкоигольной аспирационной биопсии, способом которой осуществляется получение морфологического материала для цитологического исследования.

\section{3. Околоротовые и внутриротовые мягкие ткани}

Обследование полости рта заключается в определении открывания рта, осмотре преддверия и собственно полости рта, глотки. В норме степень открывания рта соответствует 5 см или на три поперечника II, III, IV пальцев, введенных между центральными резцами. Определяют: свободно ли и безболезненно открывание рта, нет ли хруста в сочленении, каково смещение нижней челюсти в сторону. Воспалительные процессы с вовлечением жевательных мышц делают открывание рта затруднительным и болезненным. В таких случаях следует отметить сведение челюстей (воспалительная контрактура жевательных мышц I, II и III степени).

Осмотр преддверия полости рта начинают с губ, отмечая характер окраски каймы, исследуют слизистую оболочку, ее цвет, степень увлажненности, пальпируют щеку, область жирового тела щеки. Большое внимание должно быть уделено исследованию уровня прикрепления уздечек верхней и нижней губ и языка, прикреплению тяжей слизистой оболочки переходных складок. Высокое и низкое прикрепление уздечек губ (нижней и верхней) ведёт к развитию деструктивных изменений в пародонте. Если при отведении губы уздечка оттягивает десну от шейки зуба - необходима её коррекция, при возникновении ишемии в слизистой области прикрепления уздечки также необходима хирургическая коррекция.

Осмотр собственно полости рта проводят при хорошем освещении. Лучше осматривать ее с помощью лобного рефлектора или стоматологическим зеркалом с вмонтированной в него лампочкой, слизистую оболочку десен (десневой край, десневые сосочки, десневую борозду) уздечки губ, подъязычные складки и сосочки, резцовый сосочек, поперечные небные складки. При осмотре слизистой оболочки рта фиксируют внимание на малых слюнных железах - губных, щечных, молярных, небных, язычных и др. Изучение слизистой оболочки полости рта необходимо при осмотре у стоматолога любой специальности. При наличии патологических изменений в виде афт, папул, петехий, эрозий и др. необходимо направить пациента к врачу интернисту, так как многие соматические заболевания могут проявляться именно на слизистой оболочке полости рта. Результаты осмотра необходимы не только для построения правильного диагноза, но и несут в себе элементы онкологической настороженности (острые края зубов, некачественные протезы и другие травмирующие факторы - причина злокачественных новообразований слизистой оболочки рта, особенно у лиц пожилого возраста).

Особое внимание стоматолог должен обратить на слизистую оболочку миндалин и задней стенки глотки, и на способ глотания. 
При нормальном глотании губы спокойно сложены, зубы сжаты, кончик языка упирается в твёрдое нёбо за верхними резцами. Если при глотании язык упирается в верхние или нижние резцы, это способствует вестибулярному их наклону, а затем веерообразному расхождению. Причиной вестибулярного наклона и веерообразного расхождения может быть макроглоссия и неправильное развитие челюстей.

Пальпаторно исследуют альвеолярные отростки челюстей (альвеолярные дуги, альвеолярные возвышения), небный отросток верхней челюсти (носовой гребень, резцовый шов, небные ости и борозды), ткани за бугром верхней челюсти.

Делая массаж слюнных желез, следует обращать внимание на возможные характерные изменения: густую консистенцию слюны, мутный цвет, наличие в ней хлопьев, сгустков, слюнных тромбов.

При заболеваниях слюнных желез проводят зондирование протоков, что позволяет установить их направление, наличие стеноза, стриктуры или полной облитерации его, конкремент в протоке.

При осмотре языка обращают внимание на его форму, размер, состояние слизистой оболочки, ее цвет и степень влажности, выраженность сосочков. Пальпацию языка производят при выдвижении его кпереди, захватив кончик марлевой салфеткой. Исследуя глотку, осматривают мягкое небо (небный язычок, небно-язычные, небно-глоточные дужки), трубнонебную складку, небную миндалину и др., определяют глоточный рефлекс. При осмотре и исследовании подъязычных областей применяют бимануальную пальпацию: со стороны подъязычной складки и поднижнечелюстной области исследуют глубокие ткани дна полости рта.

В случае перфорации дна верхнечелюстной пазухи при удалении зуба исследуют лунку, определяют попадание жидкости через рот в полость носа. Устанавливают глубину пазухи путем введения в нее зонда. Обследуя больного с травмой костей лица, определяют патологическую подвижность, болезненность зубов, разрыв слизистой оболочки. При пальпации отломков отмечают их подвижность, крепитацию и болезненность. Обращают внимание на смыкание зубов, смещение нижней челюсти при открывании рта.

При подозрении на опухоль и опухолеподобное заболевание необходимо уточнить локализацию образования, его размеров, консистенции, подвижности, связи с зубами и др. При язве исследуют плотность ее краев, состояние дна. При выявлении язв, трещин, инфильтратов в области слизистой оболочки полости рта, языка, челюстно-лицевой области и шеи необходимо в день обращения верифицировать клинический диагноз, т.е. установить природу заболевании, используя цитологическую диагностику. Забор морфологического материала для цитологического исследования следует проводить методом соскоба, трепан-биопсии, инцизионной биопсии (мазки отпечатки), тонкоигольной аспирационной биопсии. Верификация клинического диагноза позволит избежать таких непрофильных рекомендаций как «понаблюдать». 
Осмотр полости рта при дефектах и деформациях лица и челюстей начинают с ротовой щели (форма губ), обращают внимание на открывание рта, исследуют альвеолярные и небный отростки верхней челюсти, небную кость и мягкое небо. Определяют локализацию и размер дефекта, состояние окружающей его слизистой оболочки.

Клиническое обследование пациента должно включать ряд диагностических методов и исследований. Вид и объем их зависят от характера заболевания или травмы челюстно-лицевой области, и от условий проведения обследования (в поликлинике или стационаре), и от уровня оснащенности лечебного учреждения.

Объективное обследование больного проводится с помощью клинических и специальных методов, таких как осмотр, антропометрические измерения, пальпация, перкуссия. Проводят оценку состояния органов и слизистой оболочки полости рта, зубов, зубных рядов, пародонта, оценку несъемных и съемных конструкций протезов, исследование диагностических моделей, а также лабораторные (анализ крови, мочи, слюны, биоптатов и мазков, аллергологические тесты), функциональные и рентгенологические исследования. Например (рис32)

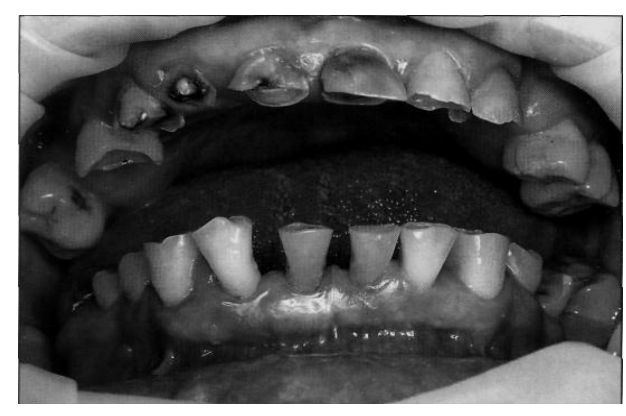

Рис. 32. Клиническая ситуация. Частичное отсутствие зубов на обеих челюстях.Неравномерное повышенное стирание твердых тканей зубов. Деформация зубных рядов. Хронический генерализованный пародонтит средне-тяжелой степени. Снижение высоты нижнего отдела лица 


\section{РАЗДЕЛ IV. ЗУБЫ И ТКАНИ ПАРОДОНТА}

Схема ООД Методы обследования с целью диагностики заболеваний органов полости рта

Классификация по МКБ-10 (Приложение 2)

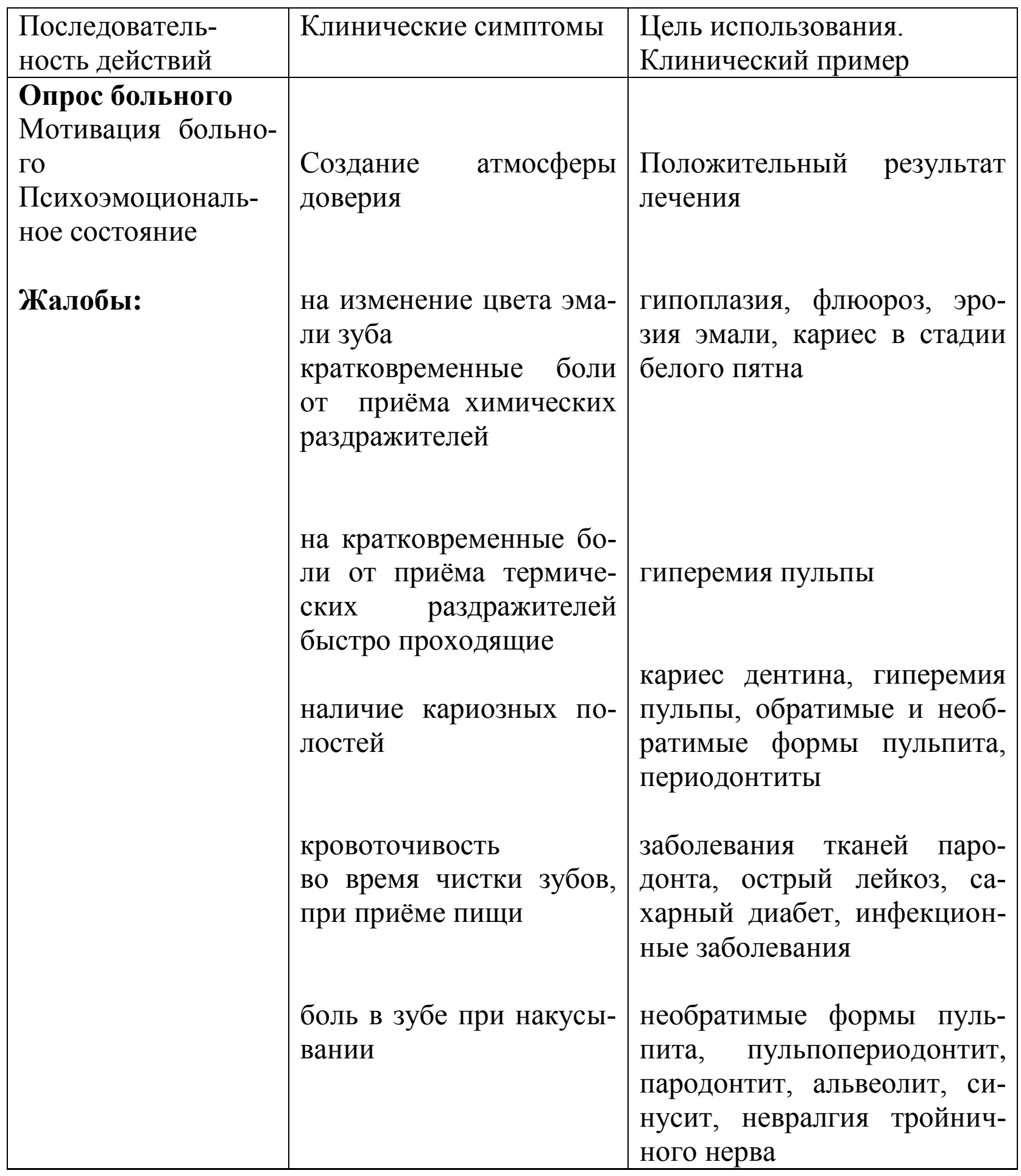


слабость, недомогание, головокружение

шум в ушах, понижение слуха, заложенность ушей

боль, усиливающаяся при разговоре, жевании

непонятная речь

сухость в полости рта, жжение языка, СОПР

ночная, самопроизвольная приступообразная локализованная боль

ночная, самопроизвольная приступообразная иррадиирующая боль ревматоидный артрит, инфекционные заболевания, заболевания ЖКТ, щитовидной железы, анемии и др.

\section{воспалительно-}

дегенеративные заболевания ВНЧС, ЛОР-болезни, гипертоническая болезнь, атеросклероз сосудов головного мозга и др.

воспалительно-

дегенеративные заболевания ВНЧС, воспалительные заболевания периодонта, пародонта, альвеолите и др.

воспалительно-

дегенеративные заболевания ВНЧС, заболевания щитовидной железы, вторичная адентия, опухоль языка

воспалительно-

дегенеративные заболевания ВНЧС, кандидоз, сахарный диабет, анемия, заболевания ЖКТ, ЦНС и др.

необратимые формы пульпита, острый верхушечный периодонтит, пульпопериодонтит, папиллит (наличие искусственной коронки или кламмера)

необратимые формы пульпита, воспалительнодегенеративные заболевания ВНЧС, синусит, альвеолит, ретроградный, конкрементозный пульпит, перекоро- 


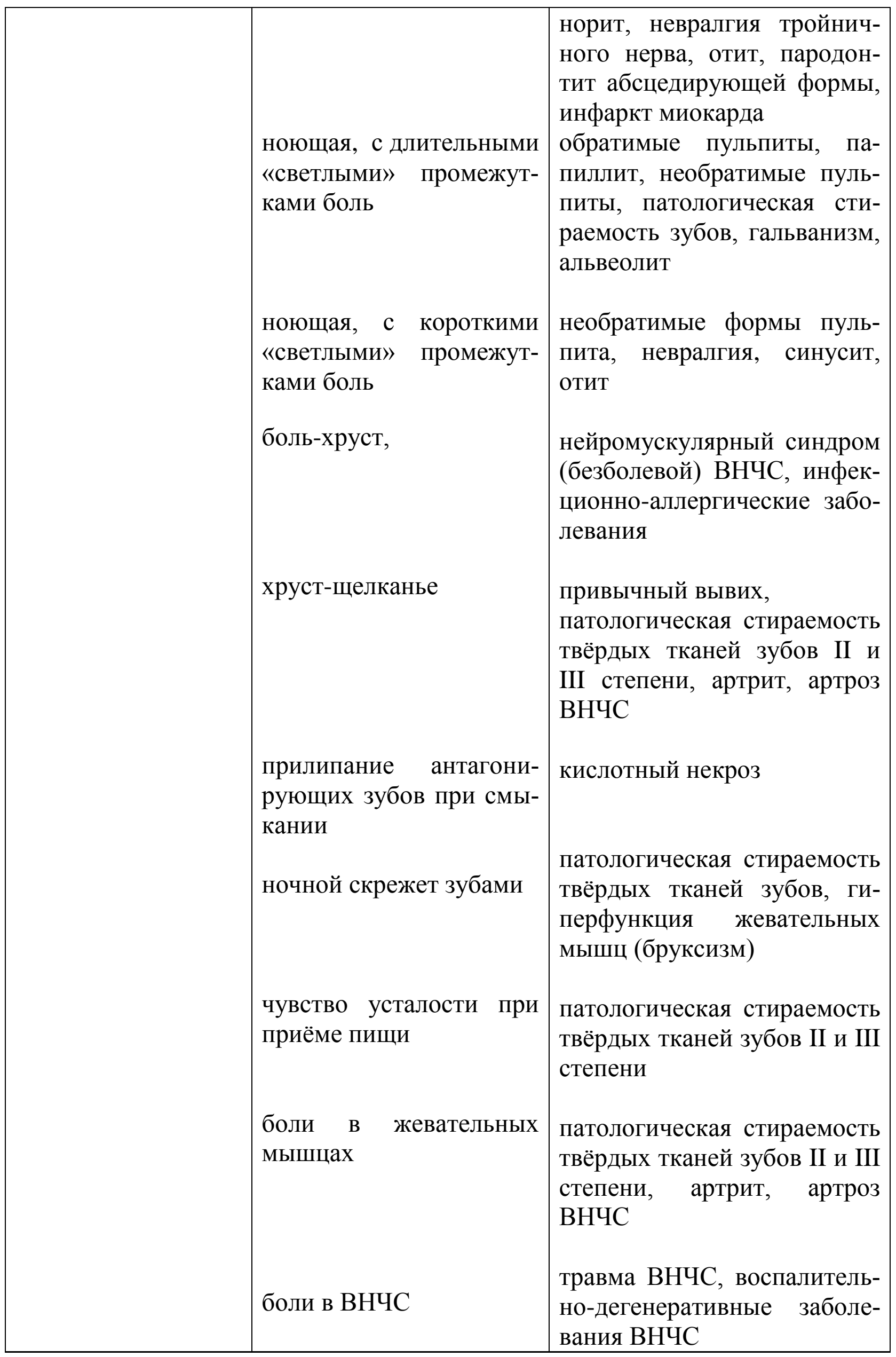




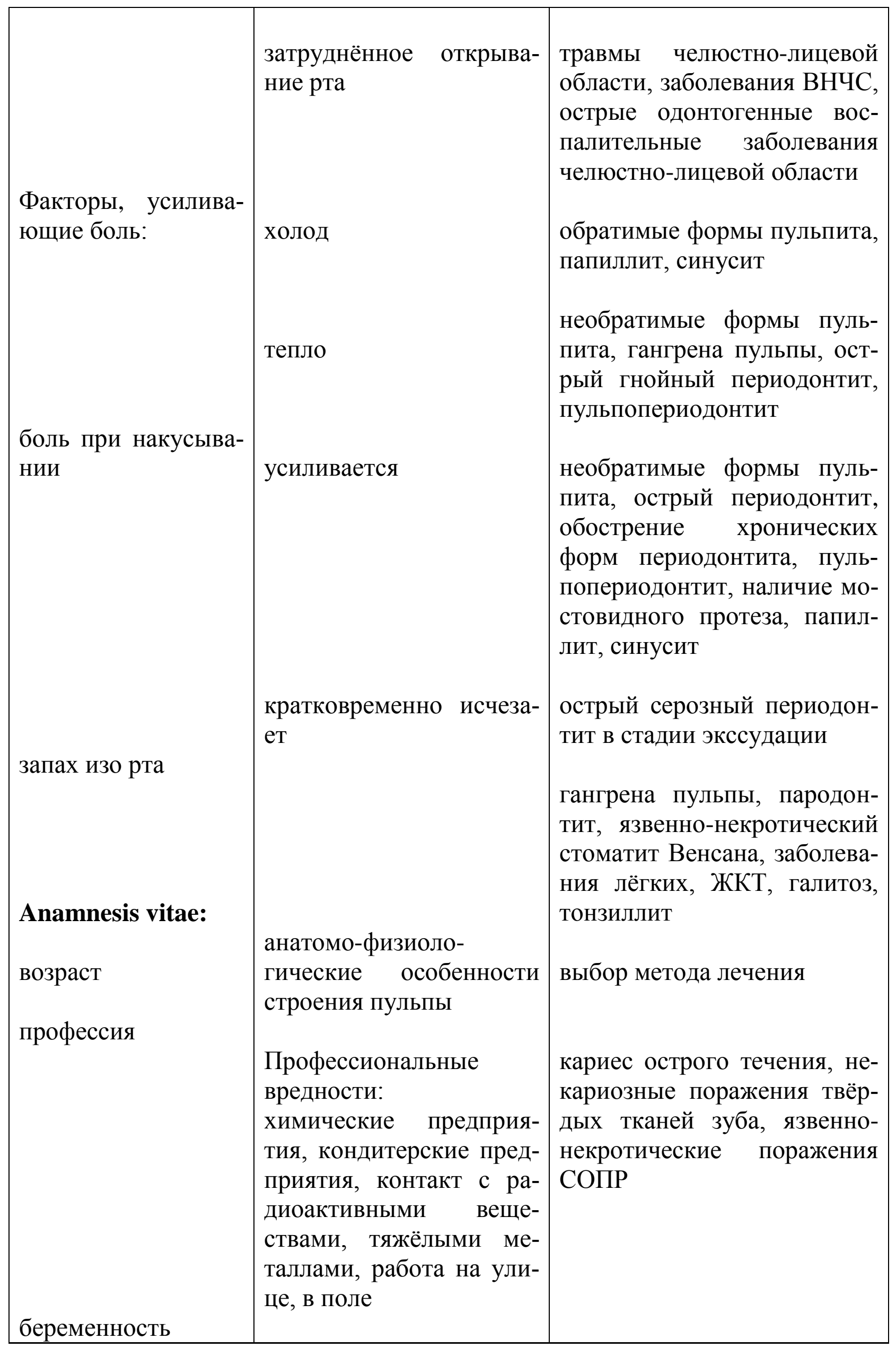




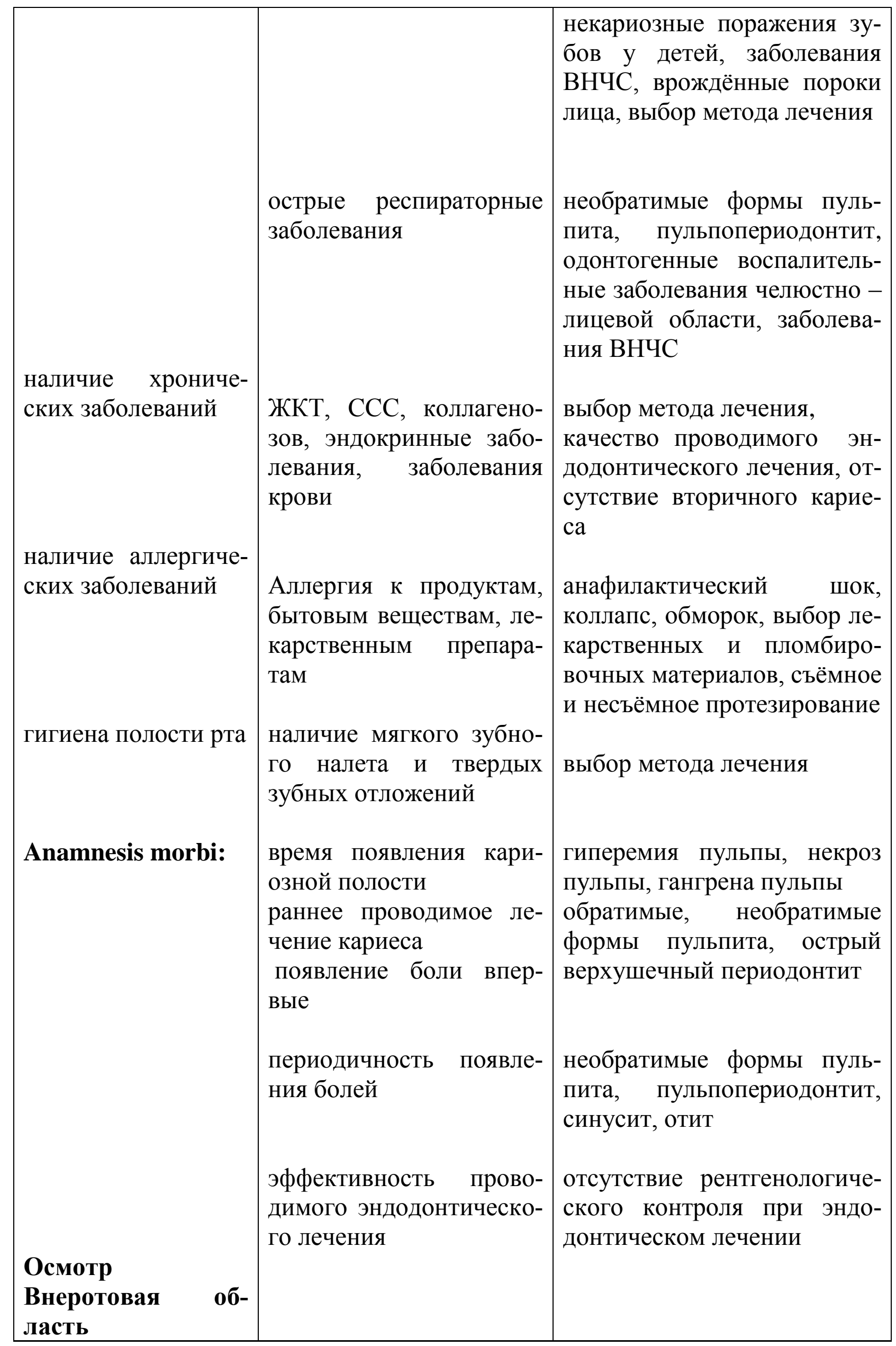




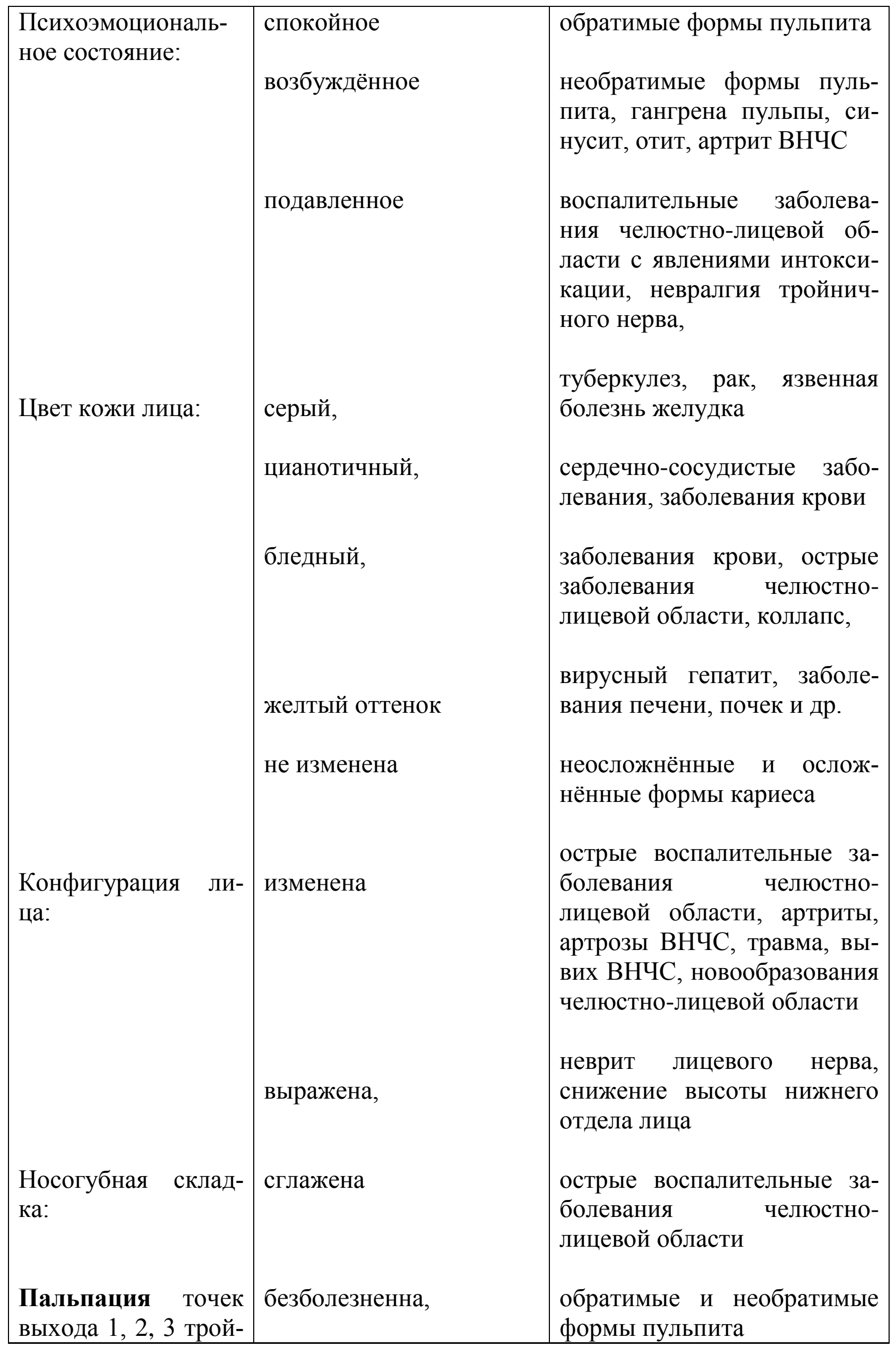




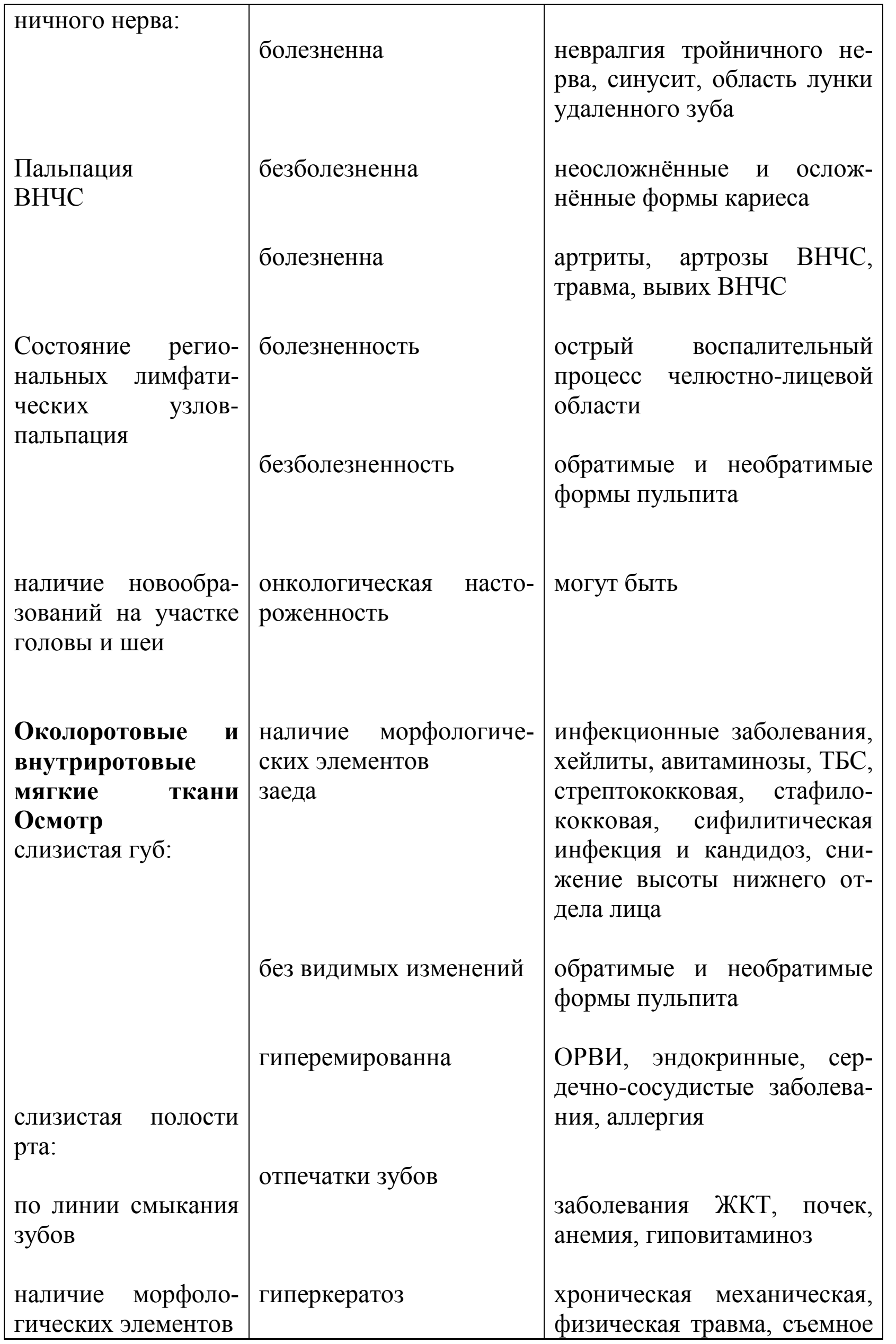




\begin{tabular}{|c|c|c|}
\hline & & протезирование \\
\hline $\begin{array}{l}\text { наличие новообра- } \\
\text { зований в полости } \\
\text { рта }\end{array}$ & $\begin{array}{l}\text { онкологическая } \\
\text { роженность }\end{array}$ & могут быть \\
\hline язык: & наличие налёта & $\begin{array}{l}\text { острые } \\
\text { воспалительные заболева- } \\
\text { ния, заболевания ЖКТ, кан- } \\
\text { дидоз, }\end{array}$ \\
\hline сосочки языка & атрофированы & $\begin{array}{l}\text { заболевания крови, канди- } \\
\text { доз }\end{array}$ \\
\hline & жёлтый оттенок & $\begin{array}{l}\text { болезнь Боткина, вирусный } \\
\text { гепатит, }\end{array}$ \\
\hline дно полости рта & $\begin{array}{l}\text { участки некроза в ме- } \\
\text { стах травмы }\end{array}$ & $\begin{array}{l}\text { сахарный диабет, заболева- } \\
\text { ния крови, протезирование } \\
\text { при частичной потере зубов }\end{array}$ \\
\hline & $\begin{array}{l}\text { жёлтый оттенок } \\
\text { бледность }\end{array}$ & $\begin{array}{l}\text { заболевания печени, болезнь } \\
\text { Боткина, вирусный гепатит } \\
\text { болезни крови, авитаминозы }\end{array}$ \\
\hline & тёмно-вишнёвый цвет & $\begin{array}{l}\text { эритремия, заболевания сер- } \\
\text { дечно-сосудистой системы }\end{array}$ \\
\hline $\begin{array}{l}\text { твёрдое и мягкое } \\
\text { нёбо }\end{array}$ & $\begin{array}{l}\text { Папилломатоз твёрдого } \\
\text { нёба }\end{array}$ & съёмное протезирование \\
\hline $\begin{array}{l}\text { Зубы и ткани па- } \\
\text { родонта }\end{array}$ & & \\
\hline $\begin{array}{l}\text { Прикус: } \\
\text { ортогнатический, }\end{array}$ & $\begin{array}{l}\text { отсутствие травматиче- } \\
\text { ской окклюзии }\end{array}$ & $\begin{array}{l}\text { проведение окклюзиограм- } \\
\text { мы }\end{array}$ \\
\hline глубокий & $\begin{array}{l}\text { наличие травматической } \\
\text { окклюзии, }\end{array}$ & $\begin{array}{l}\text { санация полости рта } \\
\text { обратимые и необратимые } \\
\text { формы пульпита, } \\
\text { пародонтит, ретроградный } \\
\text { пульпит }\end{array}$ \\
\hline прямой & скользящий & $\begin{array}{l}\text { воспалительно- } \\
\text { дегенеративные заболевания } \\
\text { ВНЧС }\end{array}$ \\
\hline КПУ >7 & наличие вторичного ка- & выбор метода лечения пуль- \\
\hline
\end{tabular}




\begin{tabular}{|c|c|c|}
\hline \multirow[t]{2}{*}{ ГИ >1 } & $\begin{array}{l}\text { риеса } \\
\text { изменение цвета зуба }\end{array}$ & $\begin{array}{l}\text { пита } \\
\text { некариозные поражения, за- } \\
\text { болевания периодонта, ре- } \\
\text { зультат эндодонтического } \\
\text { лечения, ревматизм }\end{array}$ \\
\hline & изменение формы зуба & $\begin{array}{l}\text { наследственные пороки раз- } \\
\text { вития зуба, патологическая } \\
\text { стираемость зубов } \\
\text { патологическая стираемость } \\
\text { зубов, флюороз, травма }\end{array}$ \\
\hline \multirow[t]{3}{*}{$\begin{array}{l}\text { изменение высоты } \\
\text { коронки зуба }\end{array}$} & обнажение дентина & $\begin{array}{l}\text { I степень (Бушан М. Г.) па- } \\
\text { тологической стираемости }\end{array}$ \\
\hline & $\begin{array}{l}\text { укорочение коронки зу- } \\
\text { ба, не доходящее до } \\
\text { экватора } \\
\text { (в пределах } 1 / 3 \text { длины } \\
\text { коронки зуба) }\end{array}$ & $\begin{array}{l}\text { II степень (Бушан М. Г.) па- } \\
\text { тологической стираемости }\end{array}$ \\
\hline & $\begin{array}{l}\text { укорочение коронки зу- } \\
\text { ба от } 1 / 2 \text { до } 2 / 3 \text { длины } \\
\text { коронки }\end{array}$ & $\begin{array}{l}\text { III степень (Бушан М. Г.) } \\
\text { патологической стираемо- } \\
\text { сти }\end{array}$ \\
\hline $\begin{array}{l}\text { отметить } \quad \text { зубную } \\
\text { формулу }\end{array}$ & & $\begin{array}{l}\text { отметить клинической фор- } \\
\text { мулой Виола, интенсив- } \\
\text { ность кариеса (КПУ) }\end{array}$ \\
\hline $\begin{array}{l}\text { частичная потеря } \\
\text { зубов }\end{array}$ & $\begin{array}{l}\text { классификация } \\
\text { Кеннеди }\end{array}$ & $\begin{array}{l}\text { локализованная патологиче- } \\
\text { ская стираемость твердых } \\
\text { тканей зубов, в КПУ преоб- } \\
\text { ладание значения элемента } \\
\text { «У» }\end{array}$ \\
\hline $\begin{array}{l}\text { наличие дефекта в } \\
\text { эмали и дентине зу- } \\
\text { ба }\end{array}$ & $\begin{array}{l}\text { интенсивное стирание } \\
\text { эмали и дентина сопро- } \\
\text { вождается вскрытием } \\
\text { полости зуба или обра- } \\
\text { зованием дентиклей }\end{array}$ & $\begin{array}{l}\text { эрозия эмали, гипоплазия, } \\
\text { флюороз, клиновидный де- } \\
\text { фект, кариес, патологиче- } \\
\text { ская стираемость твердых } \\
\text { тканей зубов обратимые и } \\
\text { необратимые формы пуль- } \\
\text { пита }\end{array}$ \\
\hline
\end{tabular}




\begin{tabular}{|c|c|c|}
\hline одонтопрепариро- & восстановление зубного & гиперемия пульпы \\
\hline $\begin{array}{l}\text { вание под искус- } \\
\text { ственную коронку }\end{array}$ & $\begin{array}{l}\text { ряда и анатомической } \\
\text { формы зуба }\end{array}$ & $\begin{array}{l}\text { травматический пульпит } \\
\text { конкрементозный пульпит } \\
\text { некроз пульпы травматиче- } \\
\text { ский пульпит }\end{array}$ \\
\hline $\begin{array}{l}\text { лунка } \\
\text { зуба }\end{array}$ & $\begin{array}{l}\text { отсутствие сгустка кро- } \\
\text { ви }\end{array}$ & альвеолит \\
\hline $\begin{array}{l}\text { трещины эмали зу- } \\
\text { ба }\end{array}$ & $\begin{array}{l}\text { профессиональная гиги- } \\
\text { ена полости рта }\end{array}$ & $\begin{array}{l}\text { пульпит начальный } \\
\text { ремия пульпы) }\end{array}$ \\
\hline $\begin{array}{l}\text { наличие кариозной } \\
\text { полости: }\end{array}$ & нависающие края эмали & $\begin{array}{l}\text { острое течение кариеса, } \\
\text { пульпит начальный (гипе- } \\
\text { ремия), острый, гнойный } \\
\text { (пульпарный абсцесс), }\end{array}$ \\
\hline $\begin{array}{l}\text { глубокая кариозная } \\
\text { полость }\end{array}$ & $\begin{array}{l}\text { отсутствие жевательной } \\
\text { поверхности зуба более } \\
60 \%\end{array}$ & $\begin{array}{l}\text { хронические формы пуль- } \\
\text { пита и периодонтита }\end{array}$ \\
\hline цвет дентина: & светлый & $\begin{array}{l}\text { пульпит начальный (гипе- } \\
\text { ремия пульпы), острый, } \\
\text { гнойный } \\
\text { сцесс) }\end{array}$ \\
\hline \multirow{3}{*}{$\begin{array}{l}\text { сообщение кариоз- } \\
\text { ной полости с } \\
\text { полостью зуба: }\end{array}$} & тёмный & $\begin{array}{l}\text { хронические формы пуль- } \\
\text { пита и периодонтита }\end{array}$ \\
\hline & полость зуба не вскрыта & $\begin{array}{l}\text { пульпит начальный (гипе- } \\
\text { ремия пульпы), острый, } \\
\text { гнойный } \\
\text { сцесс) }\end{array}$ \\
\hline & полость зуба вскрыта & $\begin{array}{l}\text { травматический пульпит, } \\
\text { хронический, хронический } \\
\text { гиперпластический, травма- } \\
\text { тический пульпит, бифурка- } \\
\text { ция корня }\end{array}$ \\
\hline цвет пульпы: & $\begin{array}{l}\text { розовый } \\
\text { кровоточит }\end{array}$ & $\begin{array}{l}\text { травматический пульпит, } \\
\text { хронический, хронический } \\
\text { гиперпластический, } \\
\text { травматический пульпит, }\end{array}$ \\
\hline
\end{tabular}




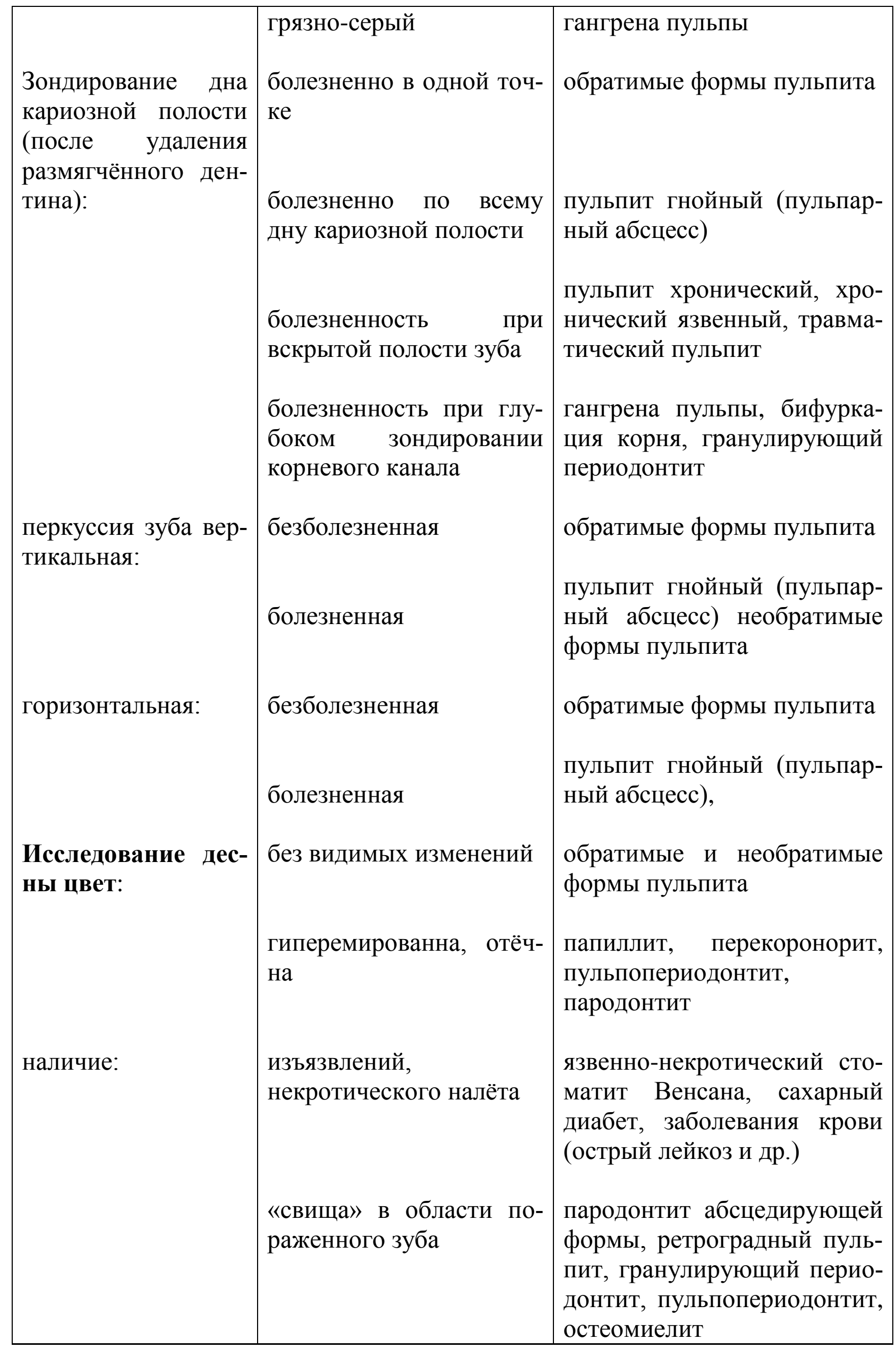




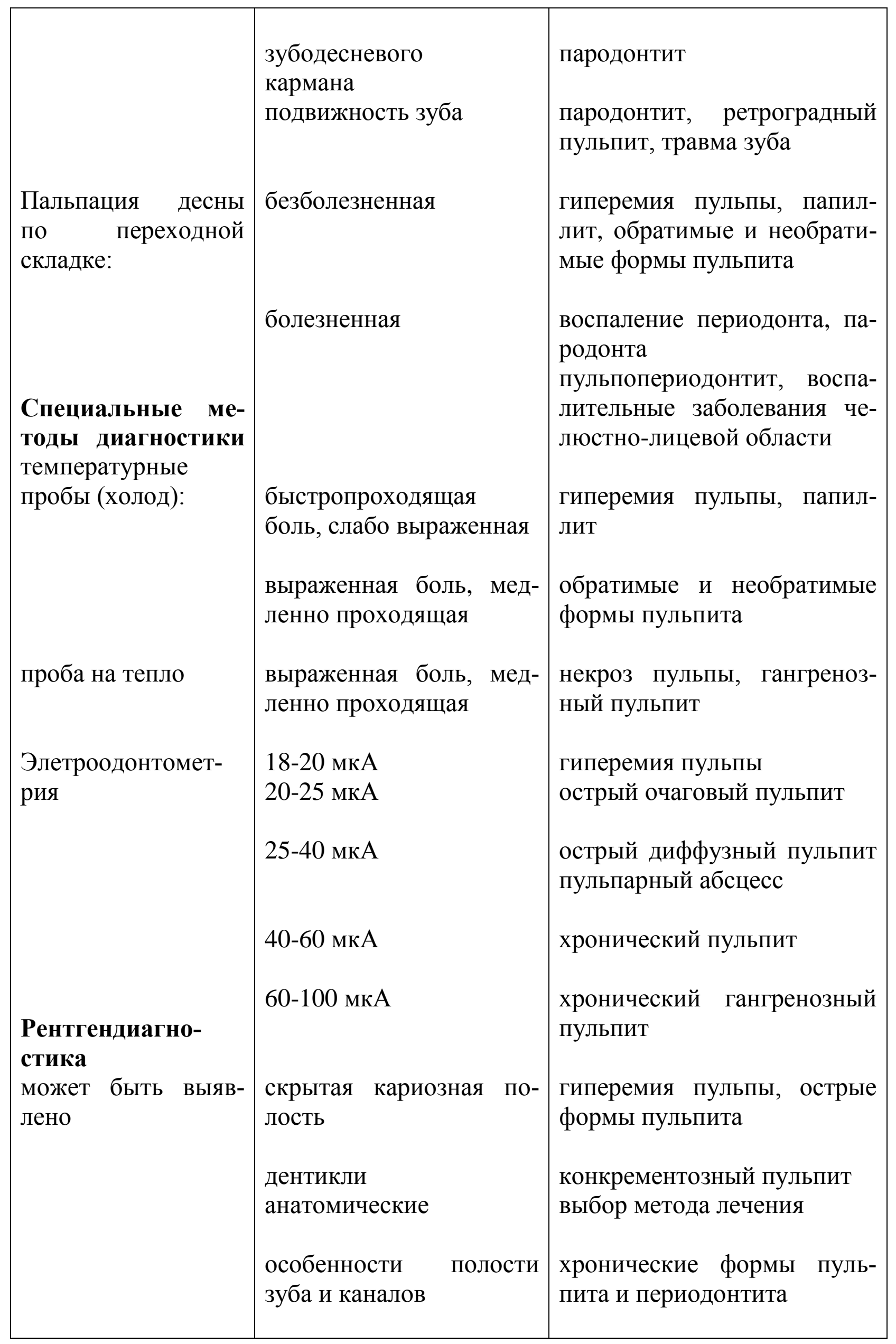




\begin{tabular}{|c|c|c|}
\hline $\begin{array}{l}\text { Сообщение кариоз- } \\
\text { ной полости с поло- } \\
\text { стью зуба }\end{array}$ & необратимое укорочение & $\begin{array}{l}\text { периапикальные } \\
\text { тельные процессы } \\
\text { пародонтит средней степени }\end{array}$ \\
\hline $\begin{array}{l}\text { одонтогенная ре- } \\
\text { зорбция }\end{array}$ & $\begin{array}{lc}\text { отдельных } \quad \text { корней } & \text { в } \\
\text { многокорневых зубах } & \end{array}$ & $\begin{array}{l}\text { тяжести, } \\
\text { пульпит, } \\
\text { пратроградный } \\
\text { ткань проникает в пульпу }\end{array}$ \\
\hline & 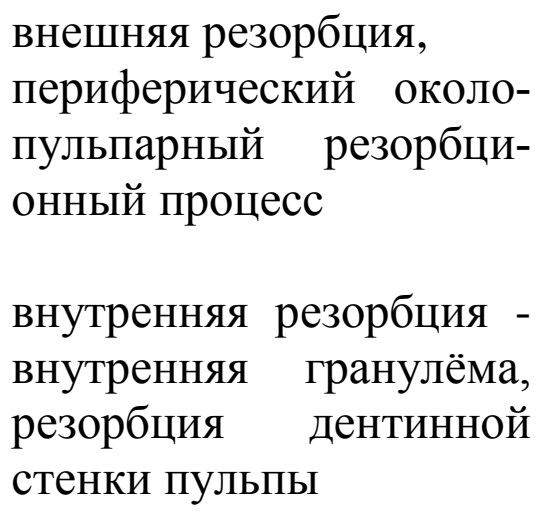 & $\begin{array}{l}\text { хронический пульпит, ган- } \\
\text { грена пульпы }\end{array}$ \\
\hline $\begin{array}{l}\text { Расширение перио- } \\
\text { донтальной щели }\end{array}$ & $\begin{array}{l}\text { в области верхушки } \\
\text { корня }\end{array}$ & $\begin{array}{l}\text { хронический фиброзный пе- } \\
\text { риодонтит }\end{array}$ \\
\hline
\end{tabular}

Проводят осмотр зубных рядов, отмечают наличие сверхкомплектных зубов, прорезывание нижних зубов мудрости, определяют характер смыкания зубов, записывают зубную формулу. Оттянув щеку шпателем, отмечают состояние сосочков околоушных желез; приподняв язык к небу, обследуют протоки поднижнечелюстных и подъязычных (большой и малые протоки) слюнных желез и выделение ими слюны.

\section{1Некариозные поражения}

Исследование отдельных зубов проводят в определенной последовательности: начиная с любой челюсти, осматривают каждый зуб в направлении от третьих моляров одной стороны до третьих моляров другой стороны. При этом определяют цвет, форму, положение, устойчивость, состояние клинических коронок зубов, количество зубов и их расположение, положение зуба (дистопия, вторичные перемещения в горизонтальной или вертикальной плоскостях). При флюорозе К00.3 (МКБ10), дисплазии или гипоплазии эмали К00.40(МКБ10), стираемости твердых тканей зуба К03. (МКБ10) наблюдается изменение цвета и формы зубов (рис.30) 


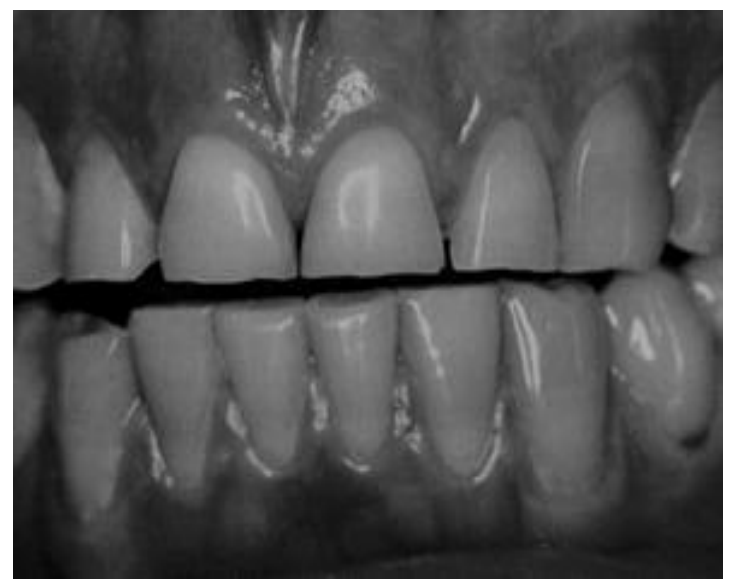

Рис. 30. Х. Смуклер. Патологическая стираемость.

Заболевание флюорозом К00.3 (МКБ10) определяется по индексу - DFI -Дину

Оценка состояния флюороза определяется по четырехбалльной системе, где 0 - нормальное - изменение эмали отсутствует; 0,5 - сомнительное - единичные белые пятна; 1,0 - незначительное - небольшие непрозрачные белые участки эмали, занимающие менее $25 \%$ поверхности зуба; 2,0 - легкое - непрозрачные белые участки эмали, занимающие $50 \%$ поверхности зуба; 3,0 - среднее - коричневые пятна, занимающие более $50 \%$ поверхности зуба; 4,0 - тяжелое - коричневые пятна охватывают всю поверхность зуба, зуб подвержен гипопластическим изменениям. Отмечаются эрозивные поражения или высокая степень стираемости. Оценке подвергаются только два наиболее пораженные зуба. Распространенность флюороза определяют процентом лиц из числа осмотренных подростков, имеющих пораженные флюорозом зубы.

СООД «Диагностические признаки флюороза К00.3, кариеса К02.0 и гипоплазии К00.40 в стадии пятна» (МКБ10)

\begin{tabular}{|c|c|c|c|}
\hline Признаки & Флюороз & Кариес & Гипоплазия эмали \\
\hline $\begin{array}{l}\text { Время } \text { возник- } \\
\text { новения }\end{array}$ & До прорезывания & $\begin{array}{l}\text { После прорезы- } \\
\text { вания }\end{array}$ & До прорезывания \\
\hline Поражённые зу- & Преимущественно & В одинаковой & Преимущественно \\
\hline бы & $\begin{array}{l}\text { постоянные (вре- } \\
\text { менные редко) }\end{array}$ & $\begin{array}{l}\text { степени вре- } \\
\text { менные и по- } \\
\text { стоянные зубы }\end{array}$ & постоянные \\
\hline Локализация & $\begin{array}{l}\text { Вестибулярная, } \\
\text { язычная (не ти- } \\
\text { пичная для карие- } \\
\text { са) }\end{array}$ & $\begin{array}{l}\text { Фиссуры и дру- } \\
\text { гие естествен- } \\
\text { ные углубле- } \\
\text { ния, контактные } \\
\text { поверхности, } \\
\text { шейки зубов. }\end{array}$ & $\begin{array}{l}\text { Вестибулярная, } \\
\text { язычная (не ти- } \\
\text { пичная для карие- } \\
\text { са) }\end{array}$ \\
\hline
\end{tabular}




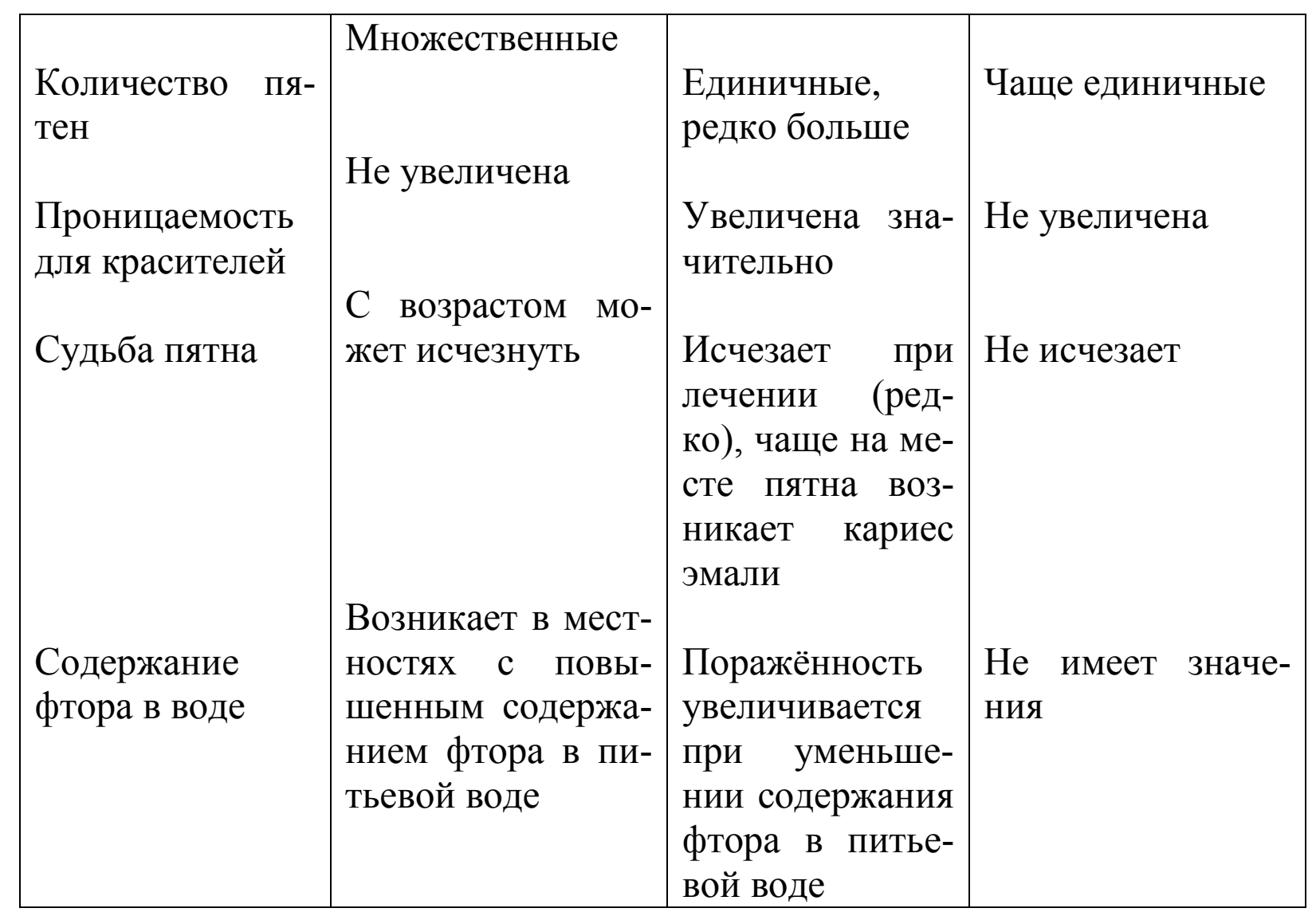

СООД «Диагностические признаки эрозивной формы флюороза К00.3»

\begin{tabular}{|c|c|c|c|}
\hline Признак & Флюороз & Кариес эмали & Гипоплазия \\
\hline Жалобы & $\begin{array}{l}\text { Эстетический } \\
\text { дефект }\end{array}$ & $\begin{array}{l}\text { Кратковременные } \\
\text { боли от химиче- } \\
\text { ских раздражите- } \\
\text { лей }\end{array}$ & $\begin{array}{l}\text { Эстетический } \\
\text { дефект }\end{array}$ \\
\hline Локализация & $\begin{array}{l}\text { Вестибулярная, } \\
\text { язычная, жева- } \\
\text { тельная поверх- } \\
\text { ность моляров }\end{array}$ & $\begin{array}{l}\text { Фиссуры и дру- } \\
\text { гие естественные } \\
\text { углубления, кон- } \\
\text { тактные поверх- } \\
\text { ности, шейки зу- } \\
\text { бов }\end{array}$ & $\begin{array}{l}\text { Вестибулярная, } \\
\text { язычная, жева- } \\
\text { тельная поверх- } \\
\text { ность моляров }\end{array}$ \\
\hline $\begin{array}{l}\text { Основной при- } \\
\text { знак очага пора- } \\
\text { жения }\end{array}$ & $\begin{array}{l}\text { Дефект эмали в } \\
\text { виде мелких или } \\
\text { крупных эрозий, } \\
\text { стёртость и ско- } \\
\text { лы эмали }\end{array}$ & $\begin{array}{l}\text { Шероховатость, } \\
\text { дефект в преде- } \\
\text { лах эмали. Зонд } \\
\text { задерживается }\end{array}$ & $\begin{array}{l}\text { Небольшие } \\
\text { углубления в ви- } \\
\text { де ямок или бо- } \\
\text { розд с гладкой } \\
\text { поверхностью }\end{array}$ \\
\hline & & Увеличена значи- & Не увеличена \\
\hline
\end{tabular}




\begin{tabular}{|l|l|l|l|}
\hline $\begin{array}{l}\text { Проницаемость } \\
\text { для красителей }\end{array}$ & Не увеличена & тельно & \\
\hline
\end{tabular}

\section{2 Кариес зубов К02}

При обследовании интактных зубов необходимо обратить внимание на поражение фиссур в виде темно-коричневой окраски или меловатобелые изменения на участках эмали. Определить поверхности, которые податливые кариесу (при отсутствии кариозных полостей, прилипание зонда на участке фиссуры) (рис33).

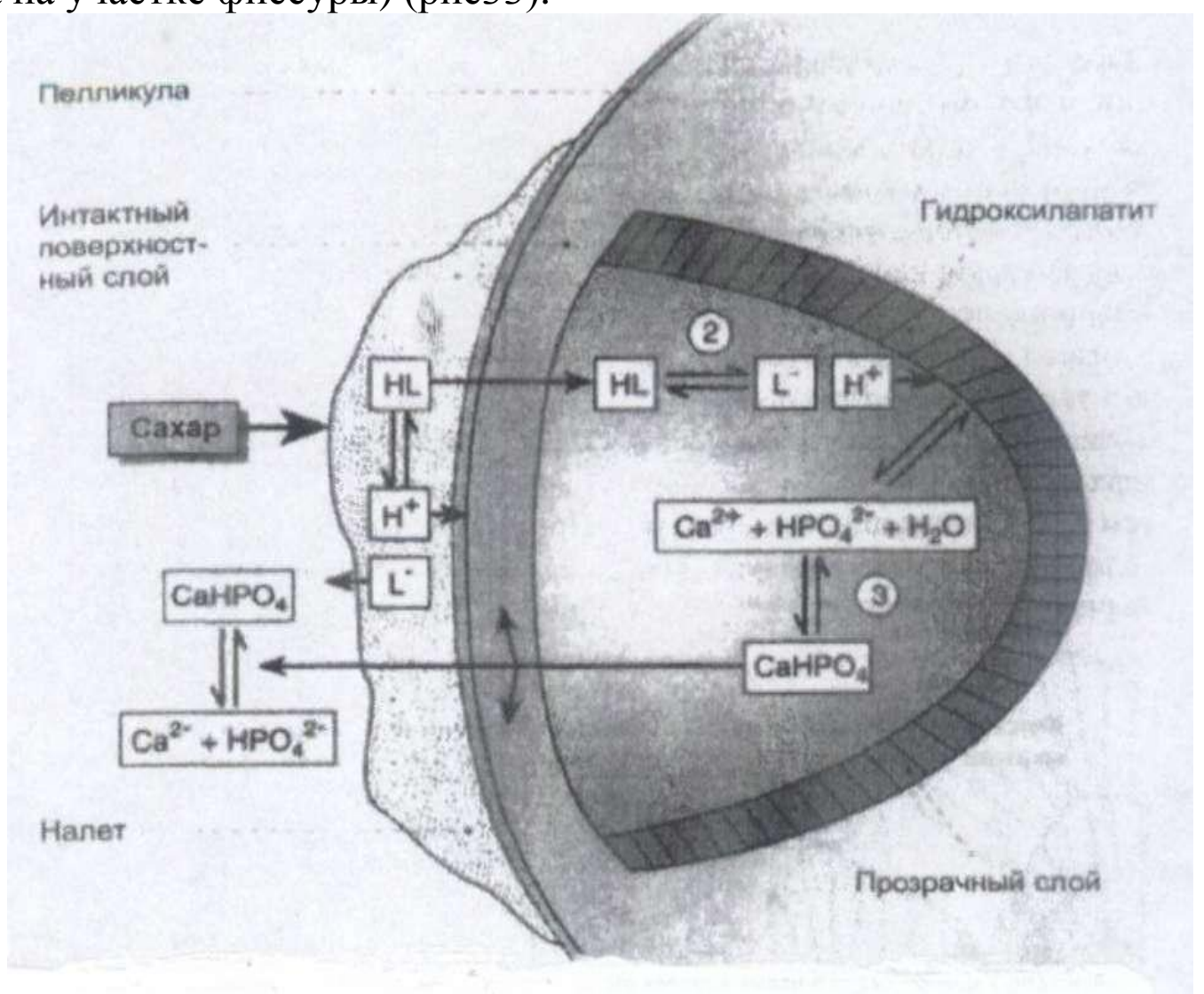

Рис. 33 Мюллер Х.П. Химические реакции при возникновении на чального кариеса эмали с образованием интактной поверхности.

При наличии дефекта твердых тканей зуба с размягченным дентином, проводят определение интенсивности кариеса (КПУ). В значение элемента «К» в структуре КПУ отмечают осложненные формы кариеса: пульпит, периодонтит и зубы, подлежащие операции удаления. Элемент «П»-ранее поставленные пломбы, элемент «У» - ранее удаленные зубы. При определении кариозной полости необходимо провести описание элементов кариозной полости: размеры кариозной полости, размеры входного отверстия, края кариозной полости, дно кариозной полости (рис.34) 


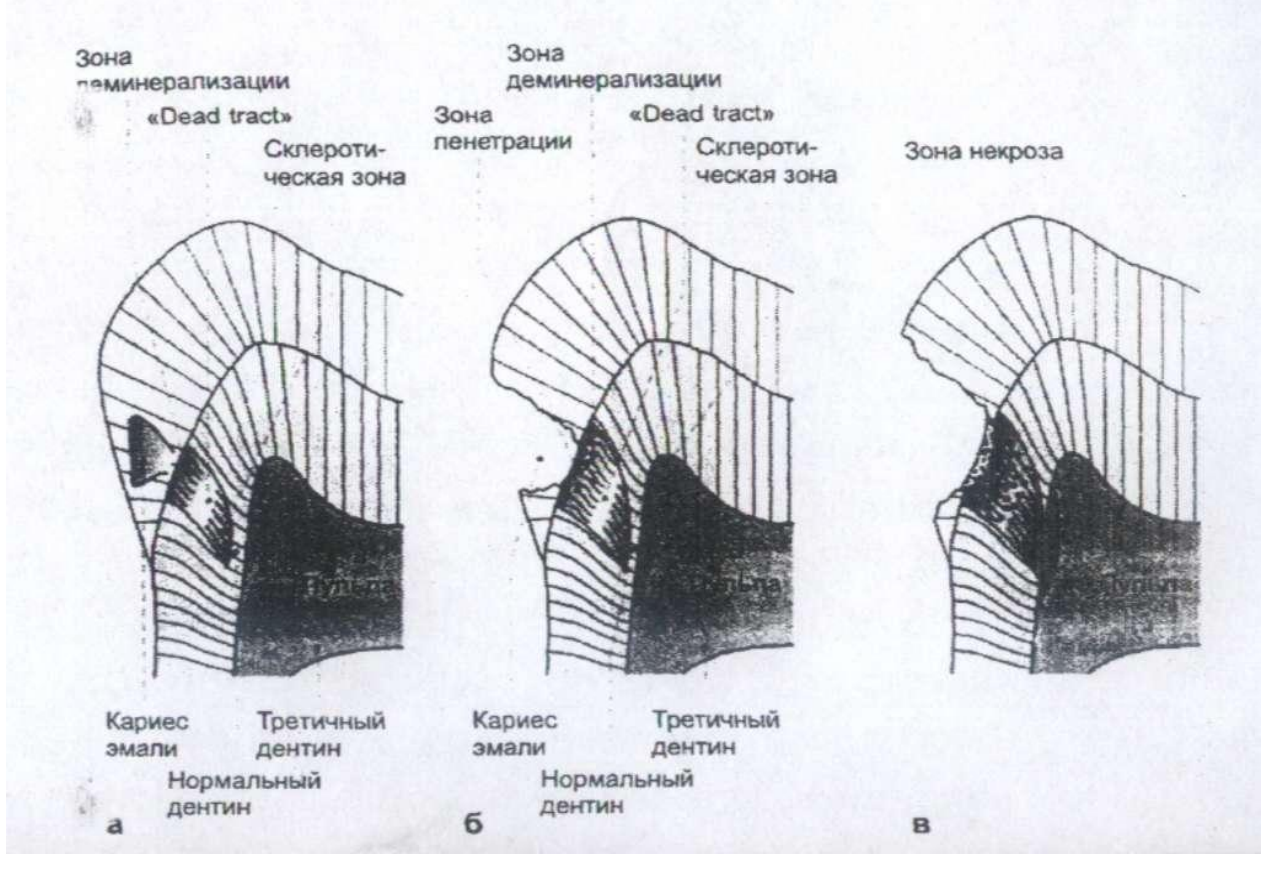

Рис. 34. Различные стадии кариеса (Мюллер Х.П.).

Схематичное изображение различных стадий кариеса дентина:

А - дентинно-пульповый комплекс реагирует гистопатологическими изменениями на кариозное поражение. На границе пульпы с дентином образуется третичный дентин. По направлению к периферии зуба располагаются слой нормального дентина, склеротическая зона, зона «Dead tracts» и на эмалево-дентинной границе - зона деминерализации.

Б - после поражения эмали микроорганизмы проникают в дентинные канальцы (зона пенетрации). Процесс кариозной деминерализации в деминерализированной зоне становится более интенсивным. Происходит распространение кариозного процесса на эмалево-дентинном соединении.

В - на продвинутых стадиях кариеса наблюдается интенсивное инфицирование дентинных канальцев. В зоне некроза обнаруживают распадающийся и размягчённый дентин, а также микроорганизмы с противолитической активностью. «Dead tracts», слои здорового, неповреждённого дентина над пульпой отсутствуют.

Классификация кариеса по локализации

К02 Кариес зубов

К02.0 Кариес эмали. Стадия «белого (мелового) пятна» (начальный кариес) К02.1 Кариес дентина

К02.2 Кариес цемента

К02.3 Приостановившийся кариес зубов

К02.4 Одонтоклазия

Детская меланодентия

Меланодонтоклазия 

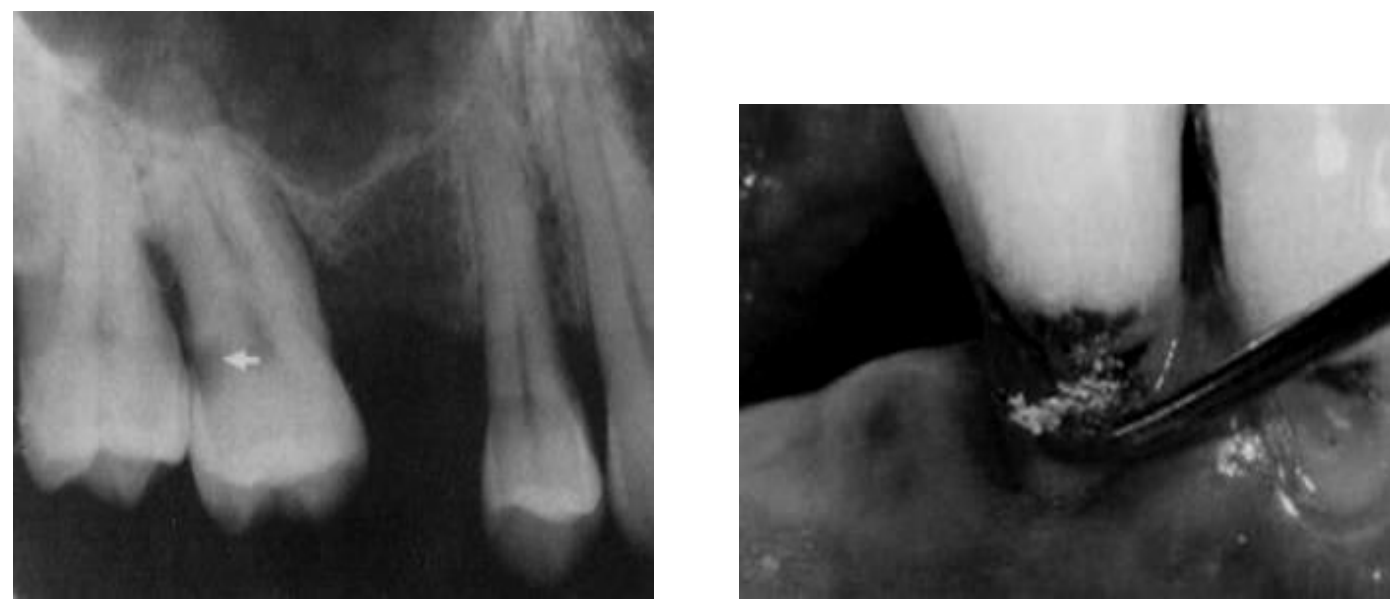

Рис. 35. Кариес цемента.

При осмотре дна кариозной полости определяют состояние полости зуба и отмечают: полость зуба - вскрыта, раскрыта, кровоточит. При зондировании полости зуба определяют болезненность, безболезненность, при зондировании устья корневого канала наличие кровоточивости, болезненность, безболезненность. Глубокое зондирование корневого канала - болезненно, безболезненно. При проведении сравнительной перкуссии - вертикальной, горизонтальной определяют болезненность или безболезненность. Наличие свищевого хода, симптом вазопареза - положительный, отрицательный. Симптом Мармассе - положительный, отрицательный.

Степень разрушения твердых тканей коронки и корня зуба необходимо определить в два этапа: до и после удаления всех размягченных тканей. После удаления размягченных тканей можно с уверенностью говорить о возможности сохранения оставшейся части твердых тканей зубов. При оценке качества пломбы определяют степень ее прилегания к тканям зуба, отсутствие или наличие вторичного кариеса, эстетический оптимум. Зубы человека могут иметь различную окраску — от молочного и белого до темно-коричневого.

Отмечают изменение цвета всей коронки или отдельных ее участков. Зубы, лишенные пульпы, становятся тусклыми, принимают сероватый оттенок, иногда имеют желтоватый оттенок в результате применения биомицина или других препаратов. При кариесе цвет зуба меняется соответственно степени выраженности патологического процесса. Амальгамы окрашивают зуб в темный цвет. При травме зуба, сопровождающейся некрозом пульпы, цвет зуба становится розоватым и со временем темнеет. Курение, а также применение различных растворов (крепкий чай, кофе) приводит к изменению цвета зубов.

Устойчивость зуба определяется пинцетом в направлениях: щечногубном, язычно-небном, медиальном, дистальном, вертикальном, соотношение внеальвеолярной и внутриальвеолярной частей зубов. 


\section{3. Заболевания пародонта. Математические индексы в стома- тологии}

При обследовании десны и альвеолярного края определяют цвет, архитектонику, тургор, ширину, отечность, подвижность. Обращают внимание на гипертрофию, величину гипертрофии десны, рецессию десны, фестончатость десневого кратера, атрофию десневых сосочков, нарушение целостности, изъязвления, кровоточивости при надавливании. Определяют наличие патологических десневых карманов, глубину в миллиметрах, выделение из них серозного или гнойного экссудата, грануляций. Наличие над- и поддесневых зубных отложений. Наличие пародонтального абсцесса. Подвижность зуба. Определение индекса CPITN, PMA, КПИ. Распространенность и интенсивность заболеваний пародонта определяется, согласно рекомендациям ВО3, по индексу CPITN и PMA.

CPITN - периодонтальный индекс потребности в лечении заболеваний тканей пародонта. Обследуют окружающие ткани на верхней и нижней челюсти в области секстантов 17/16, 11, 26/27, 37/36, 46/47. Регистрация данных индекса проводится по следующим кодам:

0 - нет признаков кровоточивости, зубного камня, патологического кармана;

1 - кровоточивость после зондирования;

2 - поддесновый зубной камень;

3 - патологический карман глубиной 3,5-5,5 мм;

4 - патологический карман глубиной 6 мм и более.

Учитывается признак наибольшей тяжести поражения путем записи значения кода у каждого из 6 обследованных зубов. По этим данным можно вычислить количество сектантов с кодами «0»- здоровый пародонт, «1» с кровоточивостью и т.д. и определить средние величины для группы обследованных.

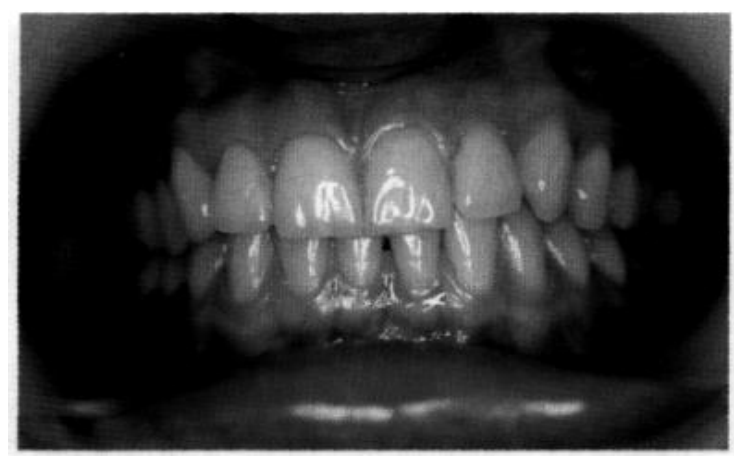

Рис. 36. Интактный пародонт. 


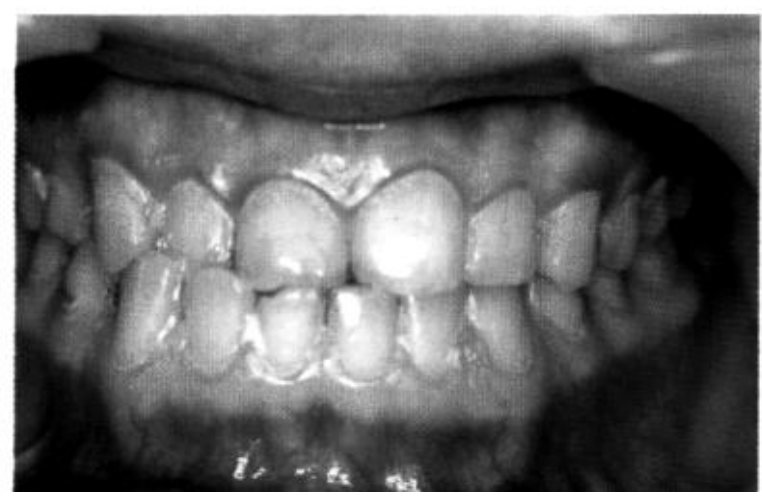

Рис. 37. Острый катаральный гингивит.

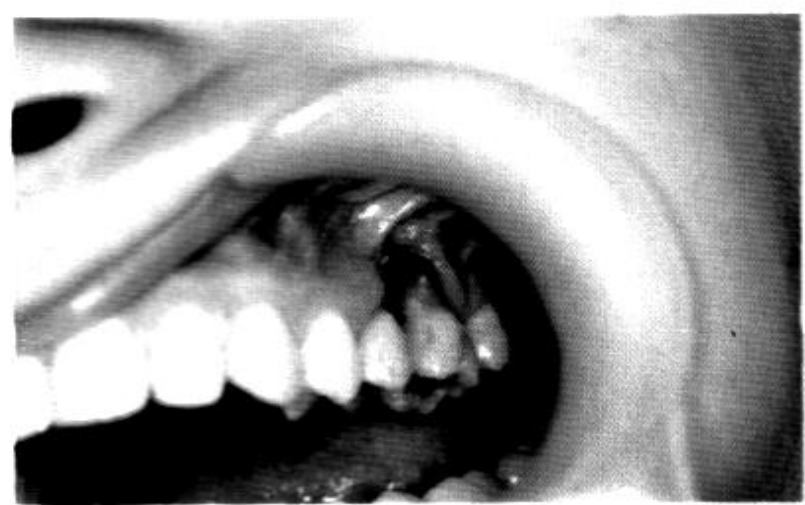

Рис. 38. Очаговый пародонтит тяжелой степени в области 15 и 16 зубов вследствие ожога мышьяковистой пастой.

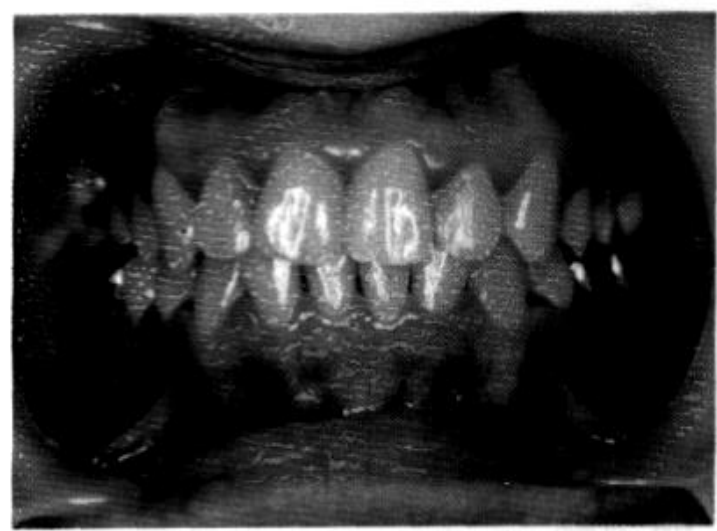

Рис. 39. Пародонтит лёгкой степени. 


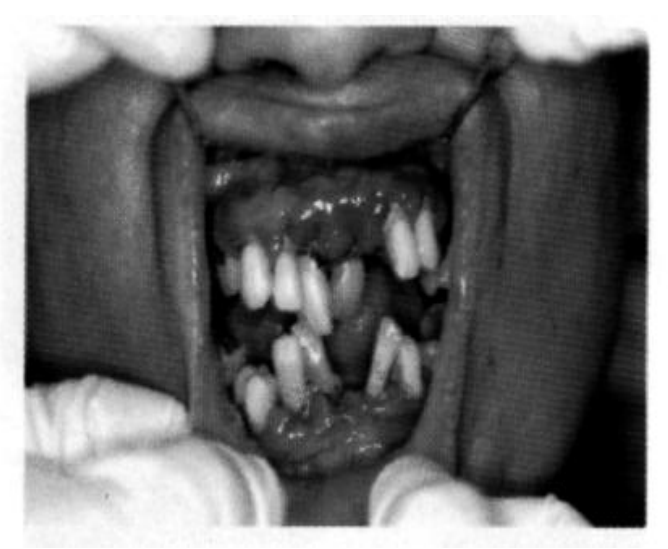

Рис. 40. Пародонтит тяжелой степени на фоне инсулинозависимого сахарного диабета.

РМА - папиллярно-маргинально-альвеолярный индекс - индекс гингивита. Воспаления сосочка (Р) оценивается баллом 1, воспаление края десны (М) - 2 воспаление альвеолярной десны (А) - 3.

Цифровое значение индекса РМА - сумма показателей состояния маргинального пародонта всех имеющихся зубов и всегда выражается целым числом.

РМА $=100 \%$ х сумма баллов $/ 3$ х 30

Для оценки гигиенического состояния полости рта применяется индекс Федорова Ю.А. Володкиной В.В. и упрощённый индекс гигиены «ИГР-У. Индекс Фёдорова Ю.А. Володкиной В.В. определяется с помощью $2 \%$ водного раствора метиленового синего. Им смазывают вестибулярные поверхности $43 ; 42 ; 41 ; 31 ; 32 ; 33$. В зависимости от количества налета окрашиваются разные участки поверхности зубов и с различной интенсивностью. Окраска оценивается качественно по трех бальной системе: интенсивно окрашенные поверхности всего зуба - 3 балла, слабое - 2 балла, отсутствие окрашивания - 1балл.

Рассчитывают по формуле $\mathrm{K}_{\mathrm{cp}}=\mathrm{E} \mathrm{Kn} / \mathrm{n}$,

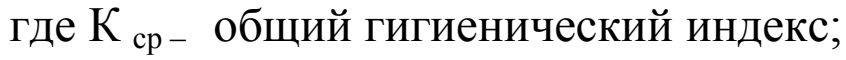

Е - сумма баллов

$\mathrm{K}_{\mathrm{n}}$ - гигиенический индекс очистки одного зуба

$\mathrm{n}$ - количество зубов

Оценочные критерии гигиены полости рта по индексу Федорова Ю.А. Володкиной В.В.: 1.1- 1.5 - хороший уровень гигиены, 1.6 - $2.0-$ удовлетворительный, $2.1-2.5$ - неудовлетворительный, 2.6 - 3.0 - плохой. Формула для расчета упрощенного индекса гигиены рта "ИГР - У" (Oni-s, Green Wermillion 1964) следующая:

ИГР $-\mathrm{y}=\mathrm{E} 3 \mathrm{H} / \mathrm{n} .+\mathrm{E} 3 \mathrm{~K} / \mathrm{n}$

$\mathrm{S}$ - сумма значений;

ЗН - зубной налет;

ЗК - зубной камень; 
$\mathrm{n}$ - количество обследованных зубов (обычно шесть зубов).

Методика: визуально с помощью зубоврачебного зонда определяется зубной налет и зубной камень на губных поверхностях 11 и 31, щечных поверхностях 1.6, 26 и язычных поверхностях 3.6 и 4.6.

0 баллов - ЗН и ЗК не обнаружен;

1 балл - ЗН и наддесневой ЗК покрывают 1/3 поверхности зуба;

2 балла - ЗН и ЗК покрывают $2 / 3$ поверхности зуба или поддесневой ЗК определяется в виде отдельных конгломератов;

3 балла - ЗН и ЗК покрывают > 2/3 поверхности зуба или поддесневой ЗК окружает пришеечную часть зуба. Оценочные критерии гигиены полости рта по индекс «Oni - s»:

0 -0,6 - уровень гигиены хороший;

0,7 - 1,6 -уровень гигиены средний;

$1,7-2,5$ - уровень гигиены плохой;

2,6 и > - уровень гигиены очень плохой.

\section{4. Способ определения интенсивности заболеваний тканей} пародонта (Приоритет изобретения 10 ноября 2002 года. Срок действия патента до 2022 года).

По определению ВОЗ «приемлемый уровень здорового пародонта» составляет 4 здоровых секстанта в возрасте 18 лет. Поэтому, при эпидемиологическом исследовании подростков Кубрушко Т.В., Гейн С.С., Гейн С.В., Фетисовой Е.В., было рассчитано среднее значение гигиены полости рта в зависимости от количества здоровых секстантов в группе осмотренных по формуле:

$$
y=b-a x
$$

Определяют гигиенический индекс (У) у каждого обследуемого, а затем значение гигиенического индекса на группу обследуемых подставляют в формулу: $y=b-a \cdot x$ и высчитывают среднее количество здоровых секстантов пародонта. Выявили, что при гигиеническом индексе равном 1,31 количество здоровых секстантов пародонта составляет 6, говорят о здоровом пародонте в обследуемой группе и хорошей профилактической работе. При гигиеническом индексе равном 2,4 и выше отсутствуют здоровые секстанты код «0», что соответствует недостаточной организации стоматологической помощи (согласно ВО3).

Выведение формулы $y=b-a \cdot x$ и расчет параметров проводились с использованием методов корреляционно - регрессионного анализа Н.Ш. Кремер, В.Е. Гмурман

Гигиенический индекс представляет собой дискретную случайную величину, изменяющуюся от 0 до 3 с шагом 0,25 .

Результаты вычислений представлены на диаграмме, на которой по оси абсцисс отложены значения интенсивности заболевания тканей пародонта, а по оси ординат - значения гигиенического индекса. Сплошной линией выделено полученное уравнение регрессии: $y_{x}=2,45-0,19 x$ 


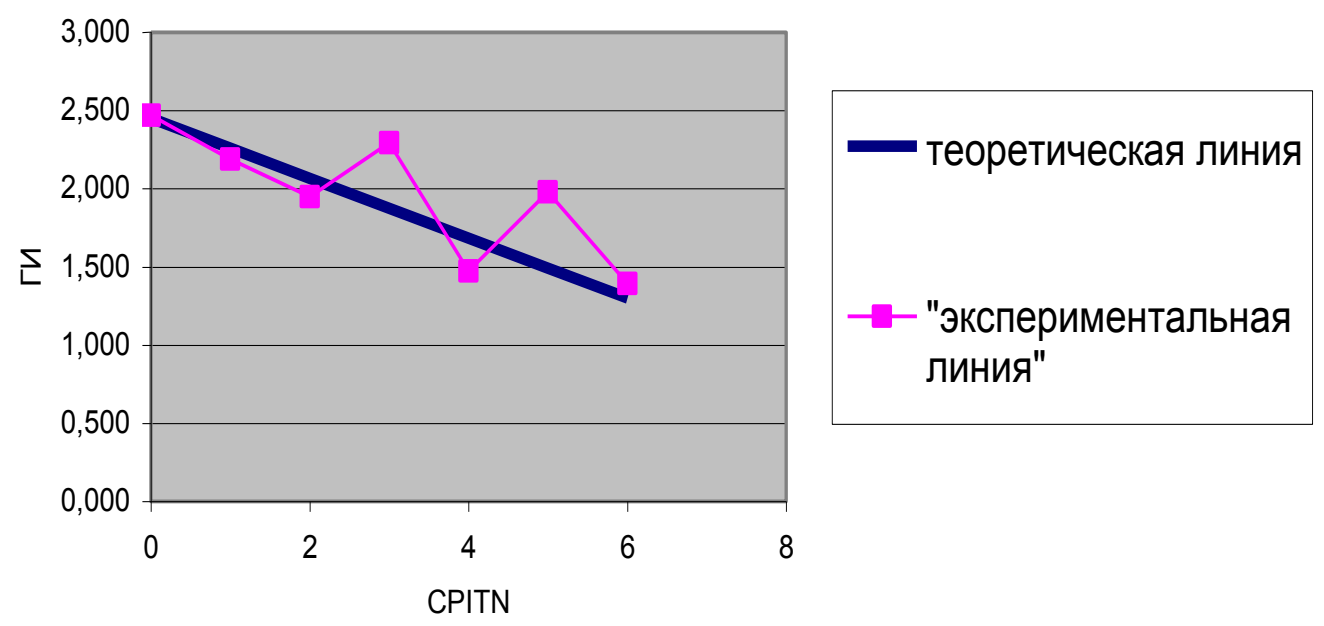

Рис. 41. Зависимость интенсивности заболевания тканей пародонта от значений гигиенического индекса.

Например: для некоторой группы 15-летних подростков среднее значение гигиенического индекса (У) равно 2,25.

Подставляя $\mathrm{y}=2,25$ в формулу $y_{x}=2,45-0,19 x$ получим: $x=\frac{2,25-2,45}{-0,19}=1,05$ для подростков в возрасте 15 лет количество секстантов, имеющих код «0» по индексу CPITN при гигиеническом индексе 2,25 равно 1,05 , т.е. в группе при гигиеническом индексе 2,25 определяется высокий уровень интенсивности заболевания пародонта. При гигиеническом индексе - 1,31 количество секстантов, имеющих код «0» равно 6, т.е. в группе подростков, имеющих гигиенический индекс 1,31 , низкий уровень интенсивности заболевания пародонта.

Таким образом, использование предложенного способа дает возможность получить объективную количественную оценку интенсивности заболеваний пародонта в полости рта без дополнительного диагностирования индекса CPITN. По установленной зависимости можно определить эффективность профилактических мероприятий при заболевании тканей пародонта по значению гигиенического индекса. Контроль гигиены не представляет затруднений и не требует много времени и может быть выполнено не только стоматологом, но и другими: врачом интернистом, средним медицинским работником.

\section{5. Рецессия десны}

В отечественной литературе для обозначения рецессии десны длительное время применялись термины «ретракция» и «атрофия» Т.Ф. Виноградова с соавторами (1983 г.) предложила называть эту патологию Vобразным атрофическим гингивитом. 


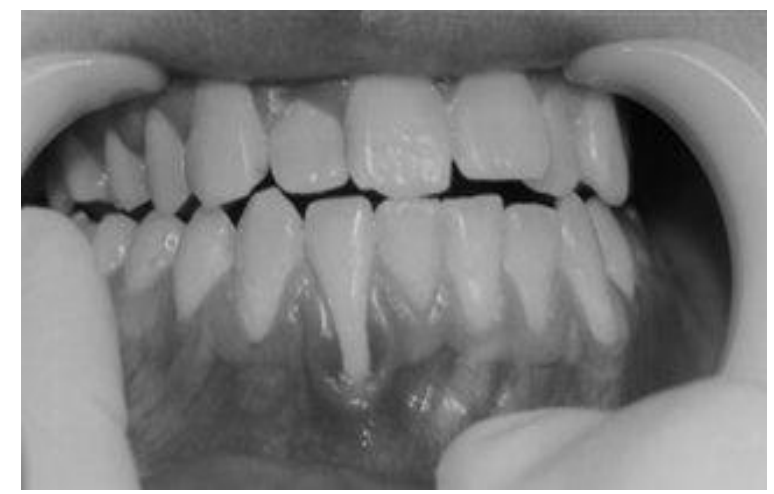

Рис.42 Рецессия десны

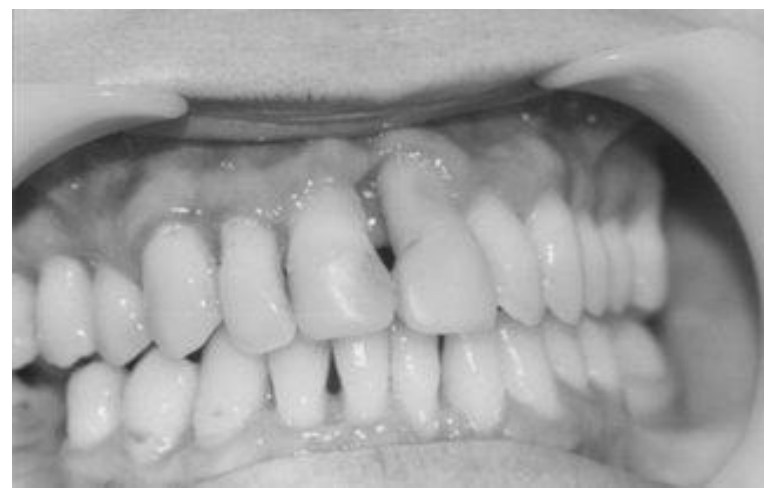

Рис. 43. Рецессия десны

Рецессия десневого края чаще всего локализуется с вестибулярной стороны в области верхних клыков и премоляров, а также нижних клыков и резцов; реже - с вестибулярной или оральной стороны верхних моляров. У пациентов 21-30 лет высота рецессии десны в среднем составляет 0,37 мм на верхней челюсти и 0,71 мм на нижней челюсти. В возрасте $31-$ 40 лет соответственно 1,1 и 1,5 мм; у людей 41-50 лет - 1,98 и 2,05 мм; в возрасте 51-60 лет - 1,11 и 2,98 мм. Более выраженная рецессия десны встречается реже, однако именно она требует серьезного хирургического лечения с целью нормализации эстетики. Наиболее распространенной во всем мире является классификация, предложенная P.D.Miller в 1985 году. I класс - рецессия в пределах свободной десны. Потеря десны и/или кости в межзубных промежутках отсутствует (подкласс А - узкая, подкласс Б - широкая) На рис.1 представлена клиническая картина рецессии десны у пациентки 3., 28 лет, на фоне мелкого преддверия полости рта.

\section{При этом выделяется 3 типа рецессий:}

I. Травматическая рецессия:

- локализованная;

- генерализованная.

II. Симптоматическая рецессия: 
- локализованная;

- генерализованная;

- системная.

\section{III. Физиологическая рецессия:}

- системная.

По степени тяжести выделяется легкая (до 3 мм), средней тяжести (3-5 мм) и тяжелая (6 и более мм) рецессия. Также рекомендовано различать 2 типа рецессии: видимую и скрытую. Видимая рецессия может быть определена врачом как расстояние от эмалево-цементной границы до десневого края (высота рецессии) и расстояние между вертикальными краями рецессии на уровне эмалево-цементной границы (ширина рецессии). Скрытая рецессия обнаруживается только при зондировании.

Зондирование пародонтальных карманов проводят с помощью углового стоматологического градуированного зонда, конец которого затуплен. Зонд вводят в периодонтальную щель с четырех сторон (вестибулярная, оральная, контактные). Погружение зонда от анатомической шейки зуба на половину вертикального размера коронки свидетельствует о глубине поражения, равной $1 / 4$ длины стенки альвеолы, на величину коронки - на $1 / 2$, погружение, равное полуторной величине коронковой части, приравнивается к атрофии $3 / 4$ вертикального размера стенки зубной альвеолы. Данные зондирования заносят в одонтопародонтограмму. 


\section{РАЗДЕЛ У. ЧАСТИЧНОЕ И ПОЛНОЕ ОТСУТСТВИЕ ЗУБОВ}

\section{1. Деформация зубных рядов и прикуса}

При осмотре десневого края обращают внимание на его соотношение с анатомической шейкой зуба. При ряде заболеваний происходит рецессия (уменьшение объема) десны за счет сокращения, укорочения, исчезновения некоторых элементов ее структуры. Определяют соотношение внеальвеолярной (коронковой) и внутриальвеолярной (корневой) части зуба (1:2 - норма, 2:1 - патологическое состояние). Изменения в опорноудерживающем аппарате зуба выявляют при помощи перкуссии. Болевые ощущения, их интенсивность информируют врача о состоянии околоверхушечных тканей. Звук, получаемый при перкуссии, позволяет выяснить состояние пульпы зуба. Депульпированный зуб с запломбированным каналом дает приглушенный звук, зуб с незапломбированным каналом формирует тимпанический звук (пустоты).

На основании рентгеновского снимка может быть выявлена степень обтурации каналов (пломбирование до верхушки корня или только его часть), а также наличие патологического процесса в окружающих его тканях и пригодность зуба (корня) в качестве опоры для протеза (коронка, штифтовый зуб, штифтовая конструкция). При наличии коронковой части зуба над уровнем десны в пределах 1-2 мм корень зуба используют под штифтовый зуб (искусственная коронка в них жестко соединена со штифтом).

При расположении корня зуба на уровне десны или ниже уровня десны (3,5-4 мм) - его используют под штифтовую конструкцию-литая культевая штифтовая вкладка и покрывная (наружная) коронка.

Исследование зубных рядов. При осмотре верхней и нижней зубных дуг определяют:

число имеющихся зубов;

наличие, топографию и протяженность дефектов в зубных рядах;

замещены или нет отсутствующие зубы протезами и их вид;

характер контактов между рядом стоящими зубами;

форма зубных дуг;

соотношение внеальвеолярной и внутриальвеолярной частей;

уровень и положение каждого зуба;

уровень окклюзионной поверхности;

наличие окклюзионной плоскости;

наличие пломб и их состояние.

Правильно сформированный зубной ряд верхней челюсти взрослого человека имеет форму эллипса, нижней челюсти - параболы. Зубы прилегают один к другому, образуя выпуклыми поверхностями коронок контактные пункты. При аномалийном прорезывании зубы могут располагаться вестибулярно, орально, выше, ниже уровня рядом стоящих зубов, мезиально, дистально, а также могут быть повернутыми вокруг оси. 
Частичное отсутствие зубов может способствовать смещению, выдвижению зубов в сторону отсутствующих антагонистов, либо наклоняться в сторону дефекта зубного ряда. Выявленное смещение зуба в любом направлении - это симптом патологического состояния зубочелюстной системы. При описании расположения зубов в зубном ряду в медицинской карте стоматологического больного отмечаются только атипично расположенные зубы, а также все отсутствующие. Вносятся данные о состоянии твердых тканей зуба и наличии зубных протезов.

\section{Зубная формула}

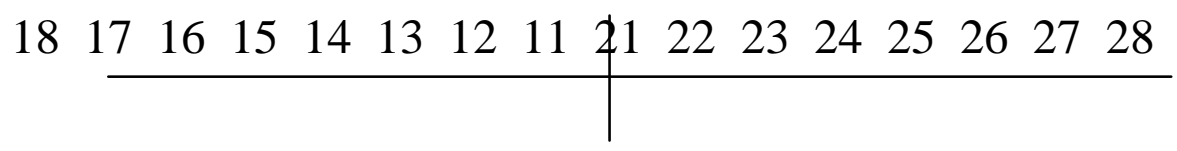

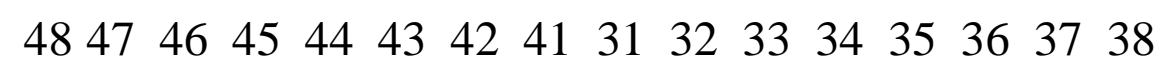

Вариантов отсутствующих зубов может быть великое множество от одного отсутствующего зуба в зубном ряду до наличия на челюсти всего одного зуба. Для систематизации этих вариантов предложены топографо-анатомические классификации дефектов зубных рядов, образующихся в результате потери зубов. Широкое применение получила классификация Кеннеди. Потеря зубов ведет к тканевой перестройке в пародонте из-за отсутствия жевательной нагрузки. Частичное отсутствие зубов (частичная вторичная адентия) непосредственным образом влияет на качество жизни пациента. Частичное отсутствие зубов обусловливает нарушение, вплоть до полной утраты, жизненно важной функции организма - пережевывания пищи, что сказывается на процессах пищеварения и поступления в организм необходимых питательных веществ, а также нередко является причиной развития заболеваний желудочно-кишечного тракта воспалительного характера.

Не менее серьезными являются последствия частичного отсутствия зубов (частичной вторичной адентии) для социального статуса пациентов: нарушения артикуляции и дикции сказываются на коммуникационных способностях пациента, эти нарушения, одновременно с изменениями внешности вследствие утраты зубов и развивающейся атрофии жевательных мышц, могут обусловить изменения психоэмоционального состояния вплоть до нарушений психики.

Частичное отсутствие зубов (частичная вторичная адентия) является также одной из причин развития специфических осложнений в челюстнолицевой области, таких, как феномен Попова-Годдона, дисфункции височно-нижнечелюстных суставов и соответствующего болевого синдрома.

Несвоевременное восстановление целостности зубных рядов при их частичном отсутствии (частичной вторичной адентии) обусловливает раз- 
витие таких функциональных нарушений, как перегрузка пародонта оставшихся зубов, развитие патологической стираемости, нарушения биомеханики зубочелюстной системы.

Особенностью данной патологии является отсутствие у пациентов болевого синдрома. При отсутствии одного или двух, а иногда и нескольких зубов больные нередко не ощущают дискомфорта и не обращаются к врачу.

Частичное отсутствие даже одного зуба в любой функционально ориентированной группе зубов может привести к развитию феномена ПоповаГодона, прямого или отраженного травматических узлов, в результате чего развивается воспаление в десневом крае, деструкция костной ткани и развитие патологических карманов, в первую очередь, в области зубов, ограничивающих дефект.

При отсутствии одного или нескольких фронтальных зубов на верхней челюсти клиническая картина характеризуется симптомом «западения» верхней губы. При значительном отсутствии боковых зубов отмечается «западение» мягких тканей щек, губ. Частичное отсутствие зубов на обеих челюстях без сохранения антагонирующих пар зубов в каждой функционально ориентированной группе зубов приводит к снижению высоты нижнего отдела лица, нередко к развитию ангулярных хейлитов («заеды»), патологии височно-нижнечелюстного сустава, изменениям конфигурации лица, выраженным носогубным и подбородочной складкам, опущению углов рта.

Частичное отсутствие жевательных зубов обусловливает нарушения функции жевания, больные жалуются на плохое пережевывание пищи.

При осмотре полости рта оценивают состояние зубных рядов, обращают внимание на число и состояние оставшихся зубов, наличие и расположение дефектов зубных рядов и их протяженность, замещены ли отсутствующие зубы или дефекты отдельных зубов ортопедическими конструкциями. В случае наличия ортопедических конструкций оценивают их функциональное состояние. Обращают внимание на характер контактов между рядом стоящими зубами, на форму зубных дуг, уровень и положение каждого зуба, уровень окклюзионной поверхности и окклюзионной плоскости (деформацию зубных рядов).

Следует обратить внимание на наличие и расположение антагонирующих пар зубов, окклюзионные контакты, соотношение зубных рядов, соотношение челюстей, вид прикуса, окклюзионные и артикуляционные соотношения зубных рядов, оценивают состояние слизистых оболочек.

При обследовании полости рта обращают внимание на выраженность и расположение уздечек и щечных складок.

Акцентируют внимание на наличие и выраженность атрофии альвеолярных отростков (рис.44). 


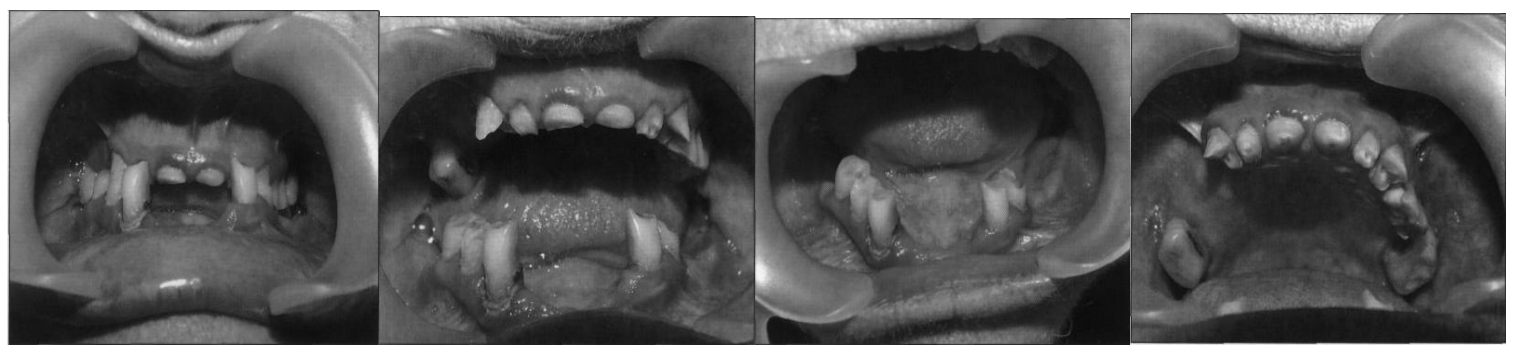

Рис. 44. Частичное отсутствие зубов на обеих челюстях. Неравномерное повышенное стирание твёрдых тканей зубов (смешанная форма). Хронический генерализованный пародонтит. Снижение высоты нижнего отдела лица на 9 мм.

Установление вида прикуса позволяет правильно сконструировать лечебный аппарат (протез), определить врачебную тактику (рис.45).

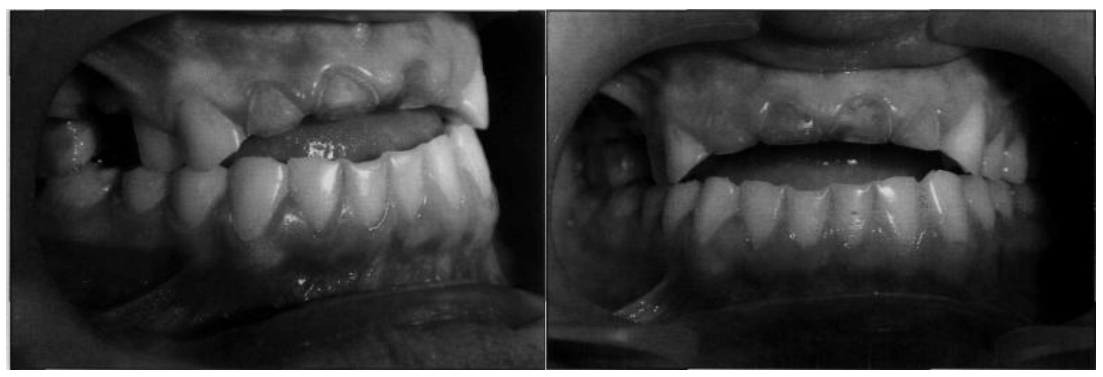

Рис. 45. Химический некроз.

Необходимо определить степень резцового перекрытия. В норме при ортогнатическом виде прикуса верхние резцы перекрывают нижние на 1/3. Если эта величина возрастает, то это характеризует наличие другого вида прикуса или патологических изменений. Одновременно с увеличением степени резцового перекрытия из-за дистального смещения нижней челюсти меняется характер окклюзионного соотношения. Очень важным обстоятельством в характеристике прикуса является наличие контакта режущих краев нижних фронтальных зубов с зубными бугорками верхних передних зубов (характерно для глубокого резцового перекрытия). Например: при прогнатии отсутствует артикулирующий контакт, а в некоторых случаях нижние зубы травмируют слизистую твердого неба, что характерно и для глубокого прикуса.

Несовпадение линии центра, вертикальной линии между центральными резцами верхней и нижней челюстей является симптомом различных заболеваний: поражение правого или левого ВНЧС, перелом челюстей, патологическая перестройка в зубных рядах из-за частичной потери зубов, наличие функции жевания только на одной стороне.

Расположение режущих краев резцов и клыков ниже красной каймы губ, значительное их обнажение при разговоре свидетельствует об их перемещении вертикально или вестибулярно Смещение в вестибулярном 
направлении сопровождается образованием диастемы и трем, а сами зубы отодвигают губу кверху, такое смещение приводит к образованию открытого прикуса или обусловливает перемещение нижних резцов вверх.

Сохранность окклюзионной поверхности имеет важное диагностическое значение и в группе жевательных зубов. При ортогнатическом, бипрогнатическом видах прикуса и физиологической прогении наблюдается плавное искривление линии зубного ряда, начиная от первого премоляра (кривая Шпее). Кривая Шпее при прямом прикусе отсутствует. Диагностическим симптомом следует считать нарушение плавности кривой, вызываемое смещением зуба или ряда зубов вверх или вниз по отношению к рядом стоящим зубам.

Деформация зубных рядов наиболее часто встречается при потере антагонистов (на нижней челюсти встречается реже). Искривление окклюзионной поверхности может наступить и при сохранении интактных зубных рядов, когда часть антагонирующих зубов подвержена патологической стираемости или окклюзионная поверхность некоторых зубов имеет некачественную (завышенную) пломбу. Аналогичная деформация может возникнуть при лечении частичного отсутствие зубов съемными протезами с пластмассовыми зубами, мостовидными протезами с пластмассовой облицовкой. В этих случаях одновременно с истиранием пломбировочного материала или пластмассовых зубов происходит перемещение антагонирующих зубов. Перестройка зубного ряда сначала возникает вблизи дефекта, а затем распространяется на весь зубной ряд. К вторичному перемещению зубов следует отнести изменение их положения не только при дефектах зубных рядов, но и при пародонтопатиях, одонтогенных опухолях и функциональной перегрузке.

Типичными являются следующие направления движения зубов: вертикальное перемещение верхних и нижних зубов, взаимное вертикальное перемещение верхних и нижних зубов, дистальное и мезиальное перемещение, наклон зубов в язычно-небном направлении, поворот зуба вокруг оси, комбинированное перемещение (веерообразное перемещение зубов).

Зубы, лишенные антагонистов, смещаются в направлении отсутствующих антагонистов противоположной челюсти, что вызывает деформацию как самого зубного ряда, так и челюсти. Подобная деформация ЗЧС у взрослого человека развивается постепенно через 3-5 лет после удаления зубов, а у детей — в течение нескольких месяцев. Лишенные антагонистов зубы могут смещаться до уровня слизистой оболочки альвеолярного отростка противоположной челюсти. В результате травмы развивается декубитальная язва. Более грозным симптомом деформации является блокирование горизонтальных жевательных движений. Блокирующие движения влекут за собой потерю зубов и функциональную перегрузку зубов, оказавшихся в блоке.

Разнообразие клинических форм зубочелюстных деформаций требует внимательного подхода к решению вопроса об устранении их при подготовке к ортопедическому лечению. 


\section{2. Обследование больного при полном отсутствии зубов.}

Отсутствие зубов непосредственным образом влияет на качество жизни пациента, обусловливает нарушение жизненно важной функции организма - пережевывания пищи, что сказывается на процессах пищеварения и поступления в организм необходимых питательных веществ, нередко является причиной развития заболеваний желудочно-кишечного тракта.

Не менее серьезными являются последствия отсутствия зубов для социального статуса пациентов: нарушения артикуляции и дикции сказываются на коммуникационных способностях пациента, эти нарушения одновременно с изменениями внешности вследствие утраты зубов и развивающейся атрофии жевательных мышц могут обусловить изменения психоэмоционального состояния вплоть до нарушений психики. Отсутствие зубов является также одной из причин развития специфических осложнений в челюстно-лицевой области, таких, как дисфункции височнонижнечелюстных суставов и соответствующего болевого синдрома.

Изменения, развивающиеся в полости рта после удаления зубов, захватывают не только альвеолярные отростки, но и слизистую оболочку, покрывающую их. Необходимо обратить внимание на степень открывания рта: характер соотношения челюстей, степень атрофии альвеолярных отростков, характер атрофии, форма альвеолярного отростка, поверхность, скат альвеолярного отростка, форму и выраженность позадимолярных бугров (рис.46).

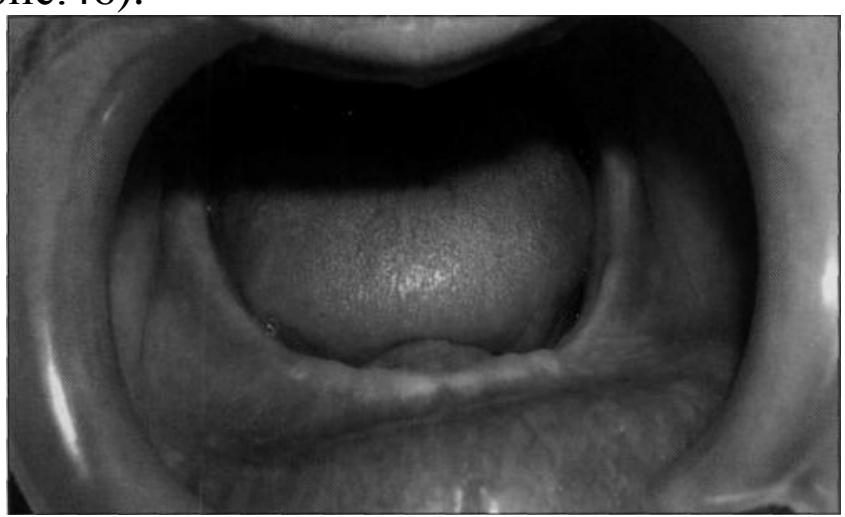

Рис. 46. Полное отсутствие зубов на нижней челюсти. Повышенная болевая чувствительность слизистой оболочки протезного ложа.

Твердое небо образовано соединением двух горизонтальных небных пластин по срединному шву. Выбухая, этот шов образует «торус», форма и размеры которого варьируют. Шов может быть плоским, втянутым и выпуклым. Необходимо отметить форму свода твердого неба (готическое, куполообразное, плоское) и его высоту (высокое, средней высоты, низкое).

Мягкое небо является непосредственным продолжением твердого неба и может иметь три формы ската (угол наклона мягкого неба к глотке) - крутой, пологий и средний. При крутом скате задний край твердого 
неба соответствует месту перехода неподвижной слизистой в подвижную (в виде узкой полосы). При пологом скате ширина пассивно-подвижной слизистой увеличивается, что позволяет удлинить базис протеза и тем самым улучшить фиксацию. Положение мягкого неба может меняться при открытой полости рта и во время откусывания пищи — мягкое небо опущено; при закрытой полости рта- несколько приподнято; при разговоре - сильно приподнято.

Определяется состояние внутренних косых линий: могут быть острые, плоские, резко выраженные, невыраженные, болезненные или безболезненные. Большое значение имеют слизистые бугорки. Они могут быть плотными, мягкими, подвижными, неподвижными или податливыми.

Анатомические образования нижней и верхней челюстей необходимо также пальпировать для обнаружения острых выступов.

Оценка состояния слизистой оболочки полости рта. Учитывают цвет и влажность. Цвет может меняться от бледно-розового до синюшного. В этих случаях необходимо дифференцировать, связано ли изменение цвета с действием протезов (гиперемия, синюшность) или с заболеваниями желудочно-кишечного тракта, инфекционными заболеваниями (беловатый налет, бледность). На слизистой щек и боковых поверхностях языка могут быть видны отпечатки зубов, декубитальные язвы, разлитая гиперемия, другая патология. Слизистая оболочка полости рта может быть подвижной, неподвижной и пассивно-подвижной. Неподвижная слизистая оболочка покрывает альвеолярный отросток и твердое небо. В области срединного шва она прикрепляется без подслизистого слоя. В боковых и задних отделах твердого неба она содержит большое количество слизистых желез, смещается только под давлением по направлению к надкостнице. Необходимо определить границы перехода неподвижной слизистой оболочки в подвижную, а в последней границу перехода пассивно-подвижной слизистой в активно-подвижную слизистую. Пассивно-подвижная слизистая - участок слизистой, имеющий выраженный подслизистый слой, может смещаться в различных направлениях.

Слизистая оболочка всегда податлива, однако степень податливости различна. Податливая слизистая оболочка не всегда подвижна. Зона пассивно-подвижной слизистой оболочки с вестибулярной стороны получила название нейтральной зоны. Место перехода активно-подвижной слизистой оболочки альвеолярного отростка в такую же слизистую щеки называют переходной складкой. Нейтральная зона не совпадает с переходной складкой, а располагается на верхней челюсти ниже, а на нижней — выше ee.

Оральная часть нейтральной зоны на верхней челюсти проходит в области перехода твердого неба в мягкое, нередко затрагивая вибрирующую зону - участок слизистой оболочки, который выявляется при произношении звука «а». Ширина пассивно-подвижной слизистой оболочки в области линии «а» может достигать 6 мм. 
Периферический край протеза, соприкасаясь с мягкими тканями, образует клапан. Клапанная зона шире зоны переходной складки. Край протеза, упираясь в переходную складку, несколько вызывает ее напряжение, а щечный скат периферического края протеза соприкасается со слизистой оболочкой щеки. Со стороны неба клапан образуется за счет погружения края протеза в пассивно-подвижные ткани на месте перехода твердого неба в мягкое нёбо. Топография клапанной зоны строго индивидуальна и зависит от ряда факторов: индивидуальной особенности строения челюсти, степени атрофии альвеолярного отростка и тела челюсти, индивидуальной особенности строения мягких тканей, покрывающих челюсти.

Слизистая оболочка, покрывающая беззубые верхние и нижние челюсти, характеризуется определенным гистологическим строением, толщиной, степенью податливости и чувствительности. Под податливостью слизистой оболочки подразумевают ее свойства сжиматься под действием давления и восстанавливать свою первоначальную форму после снятия нагрузки. Податливость можно установить при помощи ручки зонда, но для более точного определения предложены различные приборы (В.И. Кулаженко, М.Н. Соломонов, В.Ю. Курляндский и др.). В зависимости от податливости слизистой оболочки врач выбирает методику получения функционального оттиска и оттискной материал. Оценивать состояние слизистой оболочки принято по Суппле: первый класс - как на верхней, так и на нижней челюсти имеются хорошо выраженные альвеолярные отростки, покрытые слегка податливой слизистой оболочкой; небо также покрыто равномерным слоем слизистой оболочки, умеренно податливой в задней его трети; естественные складки слизистой оболочки (уздечка губ, щек и языка) как на верхней, так и на нижней челюсти достаточно удалены от вершины альвеолярной части. Второй класс - слизистая оболочка атрофирована, покрывает альвеолярные гребни и небо тонким, как бы натянутым слоем; места прикрепления естественных складок расположены несколько ближе к вершине альвеолярной части. Третий класс - альвеолярные части и задняя треть твердого неба покрыты разрыхленной слизистой оболочкой, такое состояние слизистой оболочки часто сочетается с низким альвеолярным гребнем. Четвертый класс - подвижные тяжи слизистой оболочки расположены продольно и легко смещаются при незначительном давлении оттискной массой; тяжи могут ущемляться, что затрудняет или делает невозможным пользование протезом; такие складки наблюдаются главным образом на нижней челюсти (болтающийся мягкий гребень, преимущественно при отсутствии альвеолярной части).

Тип беззубых челюстей оценивается по И.М. Оксману, классификация удобна для практического применения, так как она едина для верхних и нижних беззубых челюстей. Первый тип - высокая альвеолярная часть, высокие бугры верхней челюсти, выраженный свод неба и высокое расположение переходной складки и точек прикрепления уздечек и тяжей. Второй тип - атрофия альвеолярной части и бугров верхней челюсти средне выраженная, менее глубокое небо и более низкое прикрепление подвиж- 
ной слизистой оболочки. Третий тип - значительная, но равномерная атрофия альвеолярной части и бугров, уплощенный небный свод, подвижная слизистая оболочка прикреплена на уровне вершины альвеолярной части, Четвертый тип - неравномерная атрофия альвеолярной части, т.е. сочетаются признаки первого, второго и третьего типов.

На амбулаторном приёме врача-стоматолога, нередко обращаются пациенты после фиксации несъёмных и съёмных конструкций с жалобами на дискомфорт в полости рта. Поэтому стоматологу необходимо обратить внимание и подробно описать состояние конструкций - цвет, форма, целостность, соответствие анатомической форме естественных зубов, выраженность жевательных бугров, характер взаимоотношений при артикуляции. При несъёмном протезировании оценивают количество опорных элементов и исскуственных зубов, вид протеза, тщательно осматривают промежуточную часть протеза - отношение к альвеолярному отростку (касательная, седловидная), наличие промывного канала. Оценивают устойчивость несъёмной конструкции на естественных зубах и характер взаимоотношения с зубами-антагонистами, отмечают наличие протезов из разнородных металлов и эстетические качества.

Описывают наличие реставраций и починок базиса, толщину, форму краёв, границы базиса протеза, положение кламмеров на зубах, постановку искусственных зубов при съёмном протезировании, отмечают конструкцию (пластиночный или бюгельный), расположение дуги, характер взаимоотношения с зубами-антагонистами. Оценивают фиксацию и стабилизацию протеза во время функции. Для определения качества проведённого ортопедического лечения необходимо изготовить и сопоставить диагностические модели, которые дают возможность оценить состояние до ортопедического лечения, после одонтопрепарирования и наложения и фиксации протезов.

Итак, в результате полученной информации, следует обратить внимание на важность межпредметных знаний для постановки клинического диагноза, в основе которого лежит алгоритм диагностического процесса. 


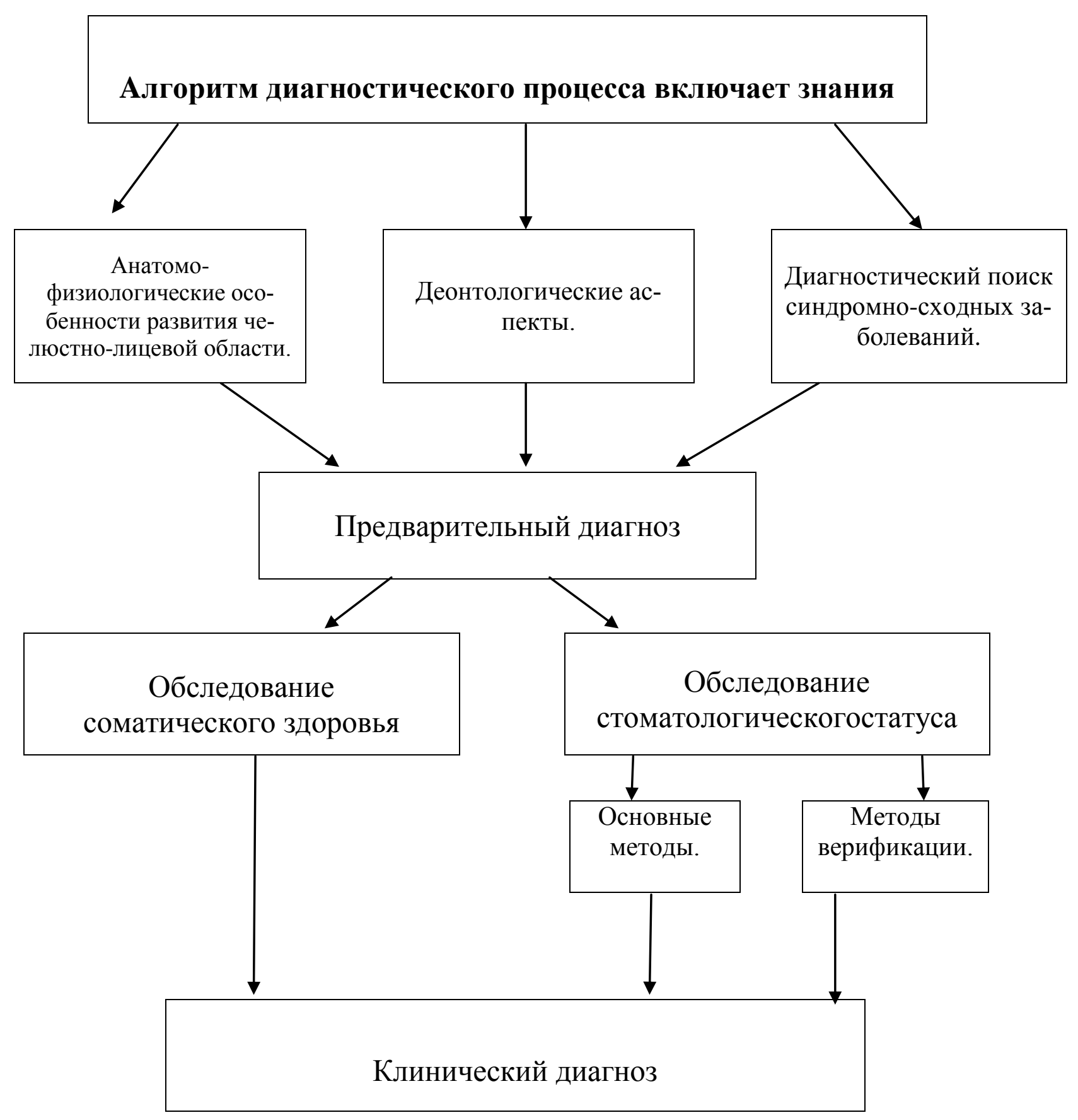




\section{6. Клинический диагноз}

Болезнь характеризуется общим или частичным снижением приспособляемости к внешней среде и ограничением жизнедеятельности того или иного органа и организма. Заболевание - возникновение болезни у отдельного человека. Каждая болезнь проявляется определённым признаком или группой признаков, представляющих собой отклонение от нормы. Этот признак называют симптомом.

Выяснение симптомов, этиологии, патогенеза, течения болезни у данного больного, его физического и психического состояния, степени, характера морфологических и функциональных нарушений возможно лишь при правильном тщательном клиническом обследовании. Чем точнее будет поставлен диагноз, тем более правильно врач составит план лечения и целенаправленнее проведёт лечение.

Врач-стоматолог при обследовании больного должен выявить не только заболевания зубочелюстной системы, но и перенесенные и сопутствующие общие заболевания (желудочно-кишечного тракта, крови, эндокринной системы и др.), так как самые ранние симптомы различных форм патологии проявляться в полости рта и на коже лица. При обследовании больного врачи-стоматологи в большинстве случаев не предусматривают изучение соматического статуса пациентов с привлечением врачейинтернистов. Остаются невыясненными заболевания внутренних органов, на фоне которых возникают нередко патологические изменения полости рта: изменения цвета, формы зубов, заболеваний тканей пародонта, слизистой оболочки полости рта, языка, губ, состояния подчелюстных лимфатических узлов, которые свидетельствуют о грозных заболеваниях организма.

\section{Пути распространения инфекции из стоматологического очага}

\begin{tabular}{|c|c|}
\hline Заболевания органов полости рта & $\begin{array}{c}\text { Осложснения, вызываемые } \\
\text { заболеваниями органов полости } \\
\text { рта }\end{array}$ \\
\hline $\begin{array}{l}\text { Осложненные формы кариеса } \\
\text { Хронические заболевания слюнных } \\
\text { желез } \\
\text { Околокорневые кисты } \\
\text { Хронический остеомиелит челюсти } \\
\text { Гингивиты } \\
\text { Пародонтиты } \\
\text { Подкожные гранулёмы } \\
\text { Воспалительные заболевания пери- }\end{array}$ & $\begin{array}{l}\text { 1. Воспалительные заболевания } \\
\text { верхних дыхательных путей (ларин- } \\
\text { гиты, тонзиллиты, бронхиты, пнев- } \\
\text { монии) } \\
\text { 2. Воздействие микроорганизмов и } \\
\text { их метаболитов, токсинов на пище- } \\
\text { варение, функцию печени } \\
\text { 3. Воздействие инфекции на сердеч- } \\
\text { но сосудистую систему. Возможное } \\
\text { распространение инфекции по сосу- }\end{array}$ \\
\hline
\end{tabular}


дам (ревматизм и пороки сердца, заболевания почек, на течение беременности, медиастенит, сепсис.

4. Распространение в полость носа (синусит, отит - через евстахиеву трубу)

5. Аллергические реакции

6. Воздействие токсинов на ЦНС и общее самочувствие

Диагностика происходит от греческого «через» и «знания», означает, что только достаточные знания о компонентах заболевания, проявлениях симптомов могут обеспечить идентификацию и постановку диагноза. Выбор диагностических методов, их использование и понимание получаемой информации основаны на знании механизмов возникновения и последующего течения патологического процесса.

Основная цель сбора диагностических данных направлена на сохранение здоровья людей.

Использование методов диагностики в лечении заболеваний служит следующим задачам: установить соответствие тяжести заболевания и степени субъективных ощущений пациента, оценить объективные критерии заболевания и поставить диагноз; выявить и исключить факторы, которые могут способствовать прогрессированию болезни.

Недостаточное обследование больного и неправильный анализ полученных данных вместо ликвидации заболевания вызывают разрушение ЗЧС, несмотря на удовлетворительные или хорошие ближайшие результаты лечения.

Диагностика - это сложный и ответственный процесс в деятельности врача, необходимыми элементами которого являются аналитическая и синтетическая работа мысли, опирающаяся на данные по изучению больного. Для правильного проведения диагностического процесса необходимо знать и уметь применять на практике все методы исследований, фиксировать и правильно трактовать полученные при этом признаки, симптомы заболеваний, знать основные и специфические признаки заболеваний зубочелюстной системы, классификацию этих заболеваний, владеть особенностями врачебного мышления.

Диагностические ошибки можно исключить только в том случае, когда общая клиническая подготовка современного врача-стоматолога способствует развитию клинического мышления, способность сопоставлять симптомы, наблюдаемые в полости рта, с общим состоянием организма и анализировать результаты инструментальных исследований. Диагностический процесс - это диалог врача с больным, который является ведущим и направляющим. 


\section{ПАМЯТКА ДЛЯ ВРАЧА}

Так как БЕСЕДА - это и познавательный аспект, и психологическое воздействие, СЛЕДОВАТЕЛЬНО, не стоит обманывать ожидания больного, но:

\begin{tabular}{|c|c|}
\hline $\begin{array}{l}\text { Какой бы мрачный прогноз не видел- } \\
\text { ся, врачу в итоге интервьо необходимо } \\
\text { помнить: }\end{array}$ & ИНАЧЕ: \\
\hline $\begin{array}{l}\text { Выражение лица врача всегда спокойное, } \\
\text { взгляд уверенный. }\end{array}$ & $\begin{array}{l}\text { Появление тревоги у больно- } \\
\text { го. }\end{array}$ \\
\hline $\begin{array}{l}\text { Понятная доступная речь без употребле- } \\
\text { ния медицинских терминов. }\end{array}$ & $\begin{array}{l}\text { Неясные моменты при обще- } \\
\text { нии, смущение больного. }\end{array}$ \\
\hline Присутствие слов ободрения. & Напряженная обстановка. \\
\hline $\begin{array}{l}\text { Внушение оптимизма, который должен } \\
\text { быть: } \\
\text { 1) достаточно взвешенным; } \\
\text { 2) сообразным имеющемуся у больного } \\
\text { представлению о его заболевании. }\end{array}$ & $\begin{array}{l}\text { 1) может быть утрачено до- } \\
\text { верие к врачу; } \\
\text { 2) спровоцировано негатив- } \\
\text { ное отношение к планируе- } \\
\text { мым методам обследования и } \\
\text { лечения }\end{array}$ \\
\hline $\begin{array}{l}\text { Акцент на обязательное избавление от } \\
\text { частых и чрезмерно беспокоящих симп- } \\
\text { томов болезни (например, боли). }\end{array}$ & $\begin{array}{l}\text { Утрата доверия к врачу и от- } \\
\text { рицательный результат лече- } \\
\text { ния. }\end{array}$ \\
\hline $\begin{array}{l}\text { Максимальное позитивное освещение не- } \\
\text { ясных моментов, подчеркивая, что забо- } \\
\text { левание: } \\
\text { - является достаточно распространенным, } \\
\text { поддающимся лечению. }\end{array}$ & \\
\hline $\begin{array}{l}\text { Совместное обсуждение хода лечения и } \\
\text { его цель. }\end{array}$ & \\
\hline
\end{tabular}

В повседневной врачебной практике, врач может увидеть лишь внешние, иногда весьма скудные и трудно различимые проявления болезни. В других случаях проявления болезни оказываются множественными, картина заболевания становится неопределённой и врачу необходимо не только отличить болезненное состояние от здоровья, но и определить форму, тяжесть и стадию развития патологии. В профессиональной деятельности врача выбор адекватных средств и методов лечения является одной из неотъемлемых и обязательных компонентов.

Одним из важнейших аспектов лечебной деятельности является диагностика заболеваний.

Без установления природы и характера заболевания невозможно осуществление адекватного лечения, контроля и оценки его эффективности. 
Целью диагностического исследования является выявление комплекса признаков (симптомов), специфически присущих, какому-либо известному заболеванию, чтобы в результате выделить из общей массы известных форм патологии ту, что следует идентифицировать как искомую для данного конкретного больного. Итогом такого диагностического исследования и анализа его результатов является клинический диагноз.

Диагноз представляет собой результат сложного процесса раскрытия сущности заболевания, отражения лежащих в основе заболевания патологических процессов и особенностей его течения в зависимости от локализации и вовлечённости в патогенетические цепочки причинноследственных связей различных систем, органов и тканей больного.

Различают три вида диагноза - клинический, патологоанатомический и судебно-медицинский. В учении о диагнозе выделяют два типа клинического диагноза - диагноз больного и диагноз болезни.

Диагноз больного даёт полную картину состояния больного с указанием этиологии и характеристику патогенетической последовательности всего комплекса функциональных и морфологических изменений и основных симптомов, определяющих клинику и морфологию заболевания. Он должен быть максимально полным, точным, нозологическим, основанным на международной номенклатуре и классификации. Клинический диагноз включает отражение видение патогенетических механизмов болезни, соотношение уровней организации живой системы, таких как участие систем управления и контроля (эндокринных органов, иммунной системы) и горизонтальных связей (межтканевых, межорганных, межсистемных) в формировании клинической, клинико-лабораторной и патологоанатомической (морфологической) картин каждого из конкретных случаев заболевания.

Диагноз болезни используется в практической и научной деятельности врачей. В целом он отвечает тем же требованиям, что и диагноз больного, но он конкретней и лаконичней диагноза больного, с акцентом на заболевание, заставившее пациента обратиться к врачу. Клинический диагноз следует начинать с ведущей нозологической единицы заболевания.

Клинический диагноз должен включать и учитывать информацию об общем состоянии больного.

Информация о соматических и системных заболеваниях необходима при составлении плана обследования и плана лечения для того, чтобы максимально решать вопросы взаимодействия в системе планируемых мероприятий с представителями смежных специальностей, помогает повысить точность прогноза заболевания, послужившим поводом для обращения к врачу.

Например, диагноз может выглядеть:

Хронический пародонтит генерализованный К05.30 Подвижность 1.3, 2.7, 3.6 зубов 1степени. Индекс CPITN Код«3»- 2 секстанта. Обнажение фуркаций в области 2.6, 2.7 зубов 2 класс А по Tarnow - Fletcher. Мелкое преддверие полости рта на нижней челюсти. Низкое прикрепление уздечки верхней губы. Прикус смешанный. Тесное положение фронталь- 
ных зубов верхней и нижней челюстей К07.30. Частичные дефекты зубных рядов- Зкл. Кеннеди К08.1 Множественные супраконтакты. К02.8 Множественный кариес зубов 2 и 5 классов по БЛЭК. Дефекты пломб в области $1.7,1.3,3.4,3,6$ зубов. Неудовлетворительное состояние гигиены полости рта: ГИ=2,2. Фон: гипертоническая болезнь II - В стадии.

\section{7. Деонтологические аспекты на амбулаторном поликлиниче- ском приёме врача-стоматолога}

Особое значение на амбулаторном поликлиническом приеме следует придавать соблюдению деонтологических норм. Деонтология - это система взглядов, представления о долге и моральных основах работы и поведения врача. Вопросы взаимоотношений врач - медицинская сестра - больной постоянно находятся в центре внимания общественных интересов и исследований, проводимых в этой области. Нормальное взаимоотношение врача и больного должны сочетать четыре компонента: поддержка, понимание, уважение, сочувствие. От подхода врача к больному зависит успех лечения. Больной должен верить врачу. Это доверие складывается из многих факторов: поведение врача и персонала, состояние кабинета, оборудования, организация рабочего места, соблюдение санитарноэпидемиологического режима при проведении лечебных манипуляций и т д. Вежливая, приветливая встреча, вызывающая у больного чувство, что его здесь ждут и ему рады, - лучший способ налаживания контакта. Мимика, выражение лица, жесты регистратора подтверждают уверенность больного в правильности выбора «своей клиники» и «своего лечащего врача». Основные принципы этики и деонтологии, которые необходимо соблюдать врачу стоматологу:

при обследовании и лечении не создавать дополнительной нагрузки на психику больного;

активно воздействовать на психику больного с целью устранения излишнего эмоционального напряжения;

больной хочет убедиться в высокой квалификации врача, умение врача донести до больного свой интеллект, стройность, ясность и конкретность клинического мышления, обоснованность и аргументированность метода лечения, стоимость лечения и гарантии;

зафиксировать у больного чувство безопасности и успеха лечения, особого отношения к нему не только на период лечения, но и на будущее;

врачи и больные в настоящее время находятся в совершенно новом правовом поле - устанавливаются договорные отношения, где определяются обязанности сторон;

законодательными актами РФ регламентируются взаимоотношения, где определяются обязанности сторон;

врач по согласованию с администрацией может отказаться от лечения больного при несоблюдении медицинских предписаний; 
врач несет ответственность за недоброкачественное выполнение своих профессиональных обязанностей и разглашение врачебной тайны.

Важнейшими деонтологическими факторами в работе врачастоматолога, влияющими на положительный исход лечения патологических состояний зубочелюстной системы, являются:

использование медикаментозных средств для снятия психоэмоционального напряжения;

исключение боли при одонтопрепарировании;

восстановления у больного эстетического и функционального оптимума;

мотивация пациента к сохранению не только здоровья органов полости рта, но и здоровья всего организма.

Медицинские работники должны взвешивать и контролировать каждое свое высказывание и обязательно учитывать впечатление, которое их беседа оказывает на больного. Необходимо напомнить слова М.Я. Мудрова о том, что во время обследования больной сам исследует медицинского работника.

Мотивация к сохранению здоровья и доверия к стоматологу основывается на определённых взаимоотношениях врача и пациента: стоматолог должен профессионально отвечать на вопросы пациента о влиянии здоровья на состояние полости рта. Выработать чувство сопричастности и общей ответственности разговора о здоровье, проявлять искреннее подчёркнутое внимание к его информации - наводящие и уточняющие вопросы, детализация и повторение сказанного. Во время беседы проявление уважения к личности пациента о его здоровье, должна быть у врача мимика соучастия, удивления, огорчения, беспокойства. Важно для врача адекватно реагировать на то, как воспринимает пациент его комментарии. При проявлении у пациента признаков ипохондрии, изменённой фиксации на своём здоровье необходимо подчеркнуть, что вы внимательно изучите информацию, и в процессе лечения будете уточнять всё то, что касается здоровья и самочувствия, в случае необходимости направите на консультацию к врачам-интернистов. В конце беседы о здоровье стоматологу необходимо демонстрировать свою ответственность за здоровье больного, показать индивидуальный подход и профессиональное мышление.

Во время амбулаторного стоматологического приёма наиболее часто встречаются в обращении с больными ошибки:

равнодушие, незаинтересованность (частая причина жалоб на врачей-стоматологов);

осуждение предыдущего стоматологического лечения, проведённого другим врачом;

дача «мудрых советов» больному (подайте жалобу на врача или обратитесь в судебные инстанции; предложите врачу вернуть деньги за некачественное лечение и т.д.); 
грубость врача с больным (всё это пустяки) и псевдоласкательное обращение к больному (золотце, милочка, голубчик, дедушка, бабуля) унижают и оскорбляют больного.

Выполнение деонтологических принципов создаёт предпосылки для успешного обследования, лечения и эффективных контактов с больными.

\section{8. Первичная документация на амбулаторном приёме врача-стоматолога}

Получение достоверной информации, отражающей в полной мере состояние здоровья пациентов, доступность медицинской помощи, ее качество и другие вопросы организации амбулаторно-поликлинической помощи требуют знания правил ведения первичной медицинской документации. Врачи не всегда оценивают значимость этой проблемы и не фиксируют внимание на основных учетно-оперативных медицинских, юридических документах, используемых в работе.

Медицинская документация - это документы установленной формы, предназначенные для регистрации результатов лечебных, диагностических, профилактических, реабилитационных, санитарно-гигиенических и других мероприятий. Она позволяет обобщать и анализировать данную информацию. Медицинская документация является учетной и отчетной, ее держателем выступают медицинские учреждения, следовательно, врачи медицинских учреждений несут ответственность за неправильное оформление соответствующих документов.

Медицинские документы являются важнейшей составной частью лечебно-диагностического процесса, обеспечивая при оказании медицинской помощи больным в амбулаторно-поликлинических условиях взаимодействие медицинских работников и мониторинг за состоянием здоровья пациентов. Только правильно оформленная первичная медицинская документация (в том числе медицинская карта) позволяет медицинскому персоналу принимать адекватные решения в конкретных клинических ситуациях.

\section{Требования к оформлению медицинской карты амбулаторного больного:}

заполнять титульный лист медицинской карты в соответствии с приказами Минздрава СССР от 31.12.1987 № 1338 и Минздравсоцразвития России от 22.11. 2004 № 225;

отражать жалобы больного, анамнез заболевания, результаты объективного обследования, клинический (верифицированный) диагноз, назначенные диагностические и лечебные мероприятия, необходимые консультации, а также всю информацию по наблюдению больного на догоспитальном этапе (профилактические медицинские осмотры, результаты диспансерного наблюдения, обращения на станцию скорой медицинской помощи и др.); 
выявлять и фиксировать факторы риска, которые могут усугублять тяжесть течения заболевания и повлиять на его исход;

излагать объективную обоснованную информацию для обеспечения «защиты» медицинского персонала от возможности жалобы или судебного иска;

фиксировать дату каждой записи;

каждая запись должна быть подписана врачом (с расшифровкой ФИО);

оговаривать любые изменения, дополнения с указанием даты внесения изменений и подписью врача;

не допускать записей, не имеющих отношения к оказанию медицинской помощи данному пациенту;

записи в амбулаторной карте должны быть последовательными, логичными и продуманными;

своевременно направлять больного на заседание врачебной комиссии и медико-социальную экспертизу;

уделять особое внимание записям при оказании экстренной медицинской помощи и в сложных диагностических случаях;

обосновывать назначенное лечение льготной категории пациентов;

предусматривать для льготных категорий больных выписку рецептов в трех экземплярах (один вклеивается в амбулаторную карту). Медицинская карта амбулаторного больного состоит из листков долговременной информации (вклеиваются в начало карты) и листков оперативной информации.

В листках долговременной информации отражаются: паспортная часть, в листе сигнальных отметок - группа крови, резус-фактор, аллергические реакции, перенесенные инфекционные заболевания.

К листку долговременной информации относится лист для записи заключительных (уточненных) диагнозов. Эти записи крайне необходимы для полноты и точности учета заболеваемости. Своевременная выписка всех диагнозов в лист заключительных диагнозов позволяет врачу легко и быстро получить сведения о прежних заболеваниях, перенесенных больным, что важно для оценки состояния его здоровья. Записи в листе заключительных диагнозов позволяют лечащему врачу решать также вопросы диспансерного наблюдения, специального лечения, необходимости в консультировании и т. д.

Впоследствии медицинская карта амбулаторного больного дополняется листками оперативной информации в порядке текущих событий. Лечащий врач в первичной медицинской документации фиксирует дату, а в некоторых случаях и час обращения в ЛПУ.

С учетом жалоб обратившегося, их детализации, анамнеза заболевания, данных объективного обследования врач устанавливает нозологическую модель пациента (приказ Минздрава России от 03.08.1999 № 303 «О введении в действие отраслевого стандарта «Протоколы ведения больных»). Модель учитывает стадию, фазу заболевания и возможные ослож- 
нения. При постановке диагноза особое внимание следует уделять его обоснованности.

На амбулаторном приёме врача-стоматолога на каждого больного заполняется медицинская карта стоматологического больного (форма 043/y), в которой последовательно должны быть отражены субъективные и объективные методы обследования, план комплексного обследования больного, обоснование клинического диагноза, план лечения, алгоритм проводимого лечения, диспансеризация. В нее четко вносят также результаты лабораторных исследований больного. Следует напомнить, что медицинская карта стоматологического больного является обязательным официальным не только врачебным и юридическим документом, но и аттестатом врачебной зрелости, свидетельствующим об уровне клинического мышления и профессиональной компетентности врача. Она предназначена для непрерывной регистрации состояния больного и результатов лечения. Медицинская карта стоматологического больного как юридический документ в течение 5 лет после последнего посещения больного хранится в регистратуре, после чего сдается в архив.

\begin{tabular}{|c|c|}
\hline & Код формы по ОКУД \\
\hline & Код учереждения по ОКПО \\
\hline Министерство здравоохранения РФ & $\begin{array}{l}\text { Медицинская документация } \\
\text { Форма № 0'43-У Утвержде- }\end{array}$ \\
\hline Наименование учреждения & $\mid \begin{array}{ll}\text { на } & \text { Минздравом } \\
04.10 .80 \text { № } 1030 & \text { СССР }\end{array}$ \\
\hline
\end{tabular}

МЕДИЦИНСКАЯ КАРТА СТОМАТОЛОГИЧЕСКОГО БОЛЬНОГО № _ 200 г.

Фамилия, имя, отчество

Возраст

Пол (м., ж.)

Адрес

Диагноз

жалобы 
Перенесенные и сопутствующие заболевания

Развитие

настоящего

заболева-

ния

Данные объективного исследования, внешний осмотр

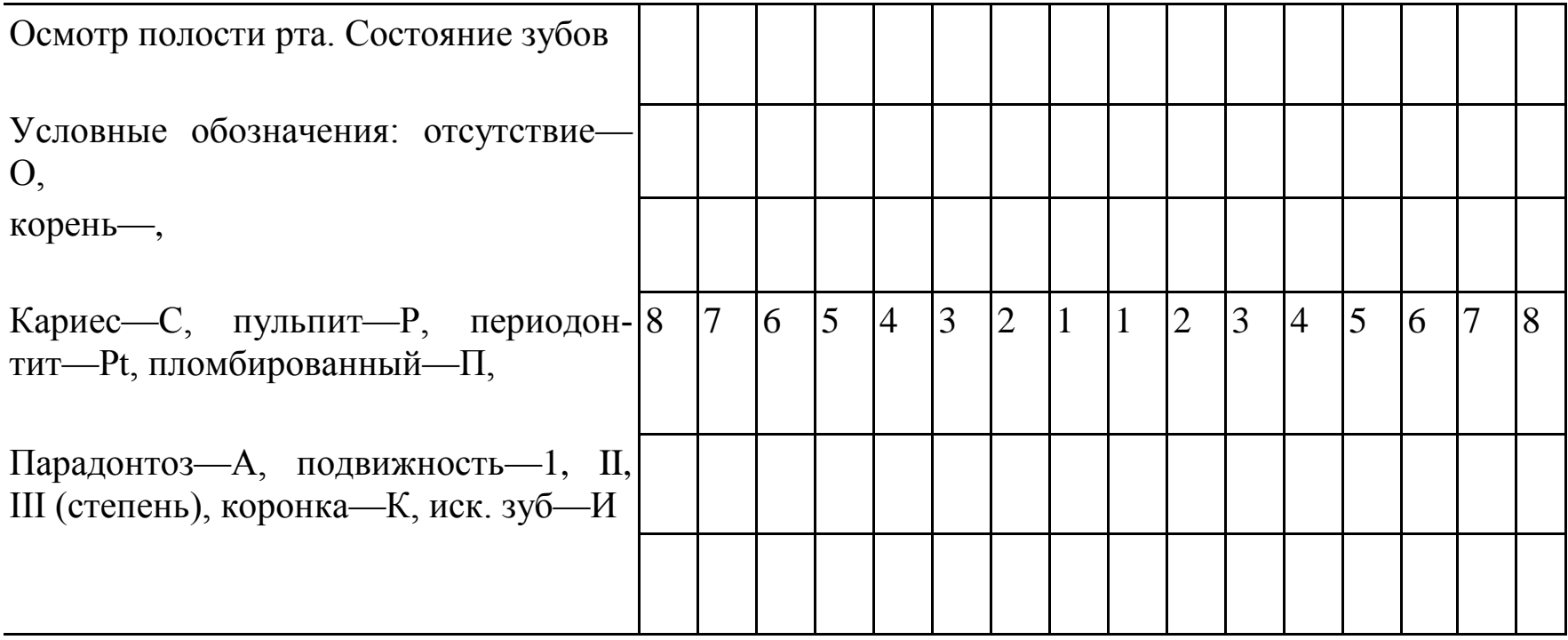

Прикус

Состояние слизистой оболочки полости рта, десен, альвеолярных отростков и неба

Данные рентгеновских лабораторных исследований

Медицинская карта стоматологического больного выполняет в клинике следующие функции: является планом для тщательного обследования больного; регистрирует данные анамнеза, обследования больного и лабо- 
раторных исследований; отражает состояние органов и тканей полости рта. Регистрирует ход лечения и изменения, наступившие в состоянии больного; дает возможность для сравнения результатов обследований, проведенных в различное время; предоставляет сведения для научных исследований; является юридическим документом.

Согласно приказа № 145 от 23 марта 2011 года МЗиСР РФ «Об утверждении показателей оценки деятельности специалистов с высшим и средним медицинским образованием, участвующих в реализации мероприятий по повышению доступности амбулаторной медицинской помощи», основными учетными медицинскими документами при оценке деятельности специалистов являются: учётная форма № 025/y-04 «Медицинская карта амбулаторного больного», учётная форма № 030/y-04 «Контрольная карта диспансерного наблюдения», учётная форма № 025-12/у «Талон амбулаторного пациента».

\section{7. Заключение}

Обзор учебно-методической литературы позволил остановиться на вопросах, которые отражены в работе А.А. Лебедева, М.В. Гончаровой «Превентивная медицина - медицина XXI века» (2008 г.), где отмечено, что главный постулат медицины XX века - лечение болезней. Медицинская помощь оказывается после визита пациента к врачу, т.е. по потребности (обращаемости). «Патология должна сформироваться, чтобы её лечить. Лечение контролируется самим врачом, решения принимаются на основании персонального опыта, личных навыков и умений. Происходит постоянное увеличение затрат на лечение заболеваний и их осложнений.

Медицина XXI века - это медицина превентивная, сохраняющая и оберегающая здоровье человека. Превентивная медицина - медицина профилактическая, принципами которой является не пассивное ожидание болезни, а проведение предупреждающих и корригирующих мероприятий задолго до развития болезни, она ориентирована в первую очередь на поддержание здоровья, улучшение ее качества, на предотвращение процессов преждевременного старения организма (Приложение 1.) Превентивная медицина с целью тщательного «сканирования» рисков заболевания использует все известные методы диагностики, позволяет обнаружить болезнь до ее клинических проявлений и вовремя принять предупредительные меры. Превентивная медицина является врачебным искусством, которым не смогут овладеть все врачи, актуальным является разработка диагностических систем, что позволяет сделать диагностику доступной для многих врачей. Стране и обществу необходима новая медицинская научно-практическая школа для распространения системного клинического мышления.

\section{Правила медицины XX и XXI века}




\begin{tabular}{|c|c|}
\hline Меді & $\begin{array}{l}\text { Медицина XXI века } \\
\text { Правила превентивной медицины }\end{array}$ \\
\hline Главный постулат-лечение болезней & $\begin{array}{l}\text { Главный постулат-сохранение } \\
\text { укрепление здоровья }\end{array}$ \\
\hline $\begin{array}{l}\text { Медицинская помощь оказывается } \\
\text { после визита пациента к врачу, т.е. } \\
\text { по потребности (обращаемости). } \\
\text { «Патология должна сформировать- } \\
\text { ся, чтобы её лечить» }\end{array}$ & $\begin{array}{l}\text { Потребность в медицинской помо- } \\
\text { щи предугадывается (просчитывает- } \\
\text { ся). Медицинское обслуживание ос- } \\
\text { новывается на постоянном наблю- } \\
\text { дении - динамическом мониторинге } \\
\text { здоровья }\end{array}$ \\
\hline $\begin{array}{l}\text { Лечение контролируется самим вра- } \\
\text { чом, решения принимаются на ос- } \\
\text { новании персонального опыта, лич- } \\
\text { ных навыков и умений }\end{array}$ & $\begin{array}{l}\text { Пациент - главный контролёр (па- } \\
\text { циент имеет право привлекать неза- } \\
\text { висимых экспертов для контроля ка- } \\
\text { чества оказываемой медицинской } \\
\text { помощи). Решения, принимаемые } \\
\text { врачом о назначении лечения, от- } \\
\text { крыты для пациента }\end{array}$ \\
\hline $\begin{array}{l}\text { Постоянное увеличение затрат на } \\
\text { лечение заболеваний и их осложне- } \\
\text { ний }\end{array}$ & $\begin{array}{l}\text { Постоянное сокращение потерь, свя- } \\
\text { занных с утратой здоровья (увели- } \\
\text { чение продолжительности жизни). }\end{array}$ \\
\hline $\begin{array}{l}\text { Монолог врача } \\
\text { Врач - пациент }\end{array}$ & $\begin{array}{l}\text { Диалог между врачом и пациентом } \\
\text { Врач - пациент }\end{array}$ \\
\hline
\end{tabular}

Поэтому, данное пособие предназначено в помощь врачу для развития системного клинического мышления.

Для диагностического поиска синдромно-сходных заболеваний на врачебном приёме врача-стоматолога общей практики необходимы знания прикладной анатомии челюстно-лицевой области, которые позволяют обнаружить болезнь до ее клинических проявлений и вовремя принять предупредительные меры. В пособии отмечено, что в зубочелюстной системе чаще всего наблюдается сочетание различных заболеваний и их осложнений независимо от жалоб больного и клинических симптомов необходимо исследовать всю зубочелюстно-лицевую область и каждый ее орган, оценивать общее состояние организма, уточнять сопутствующие общесоматические заболевания, применяя так называемый методический тип диагностического исследования.

В диагностический поиск синдромно-сходных заболеваний включены такие направления, как острая и хроническая боль, парестезии, нарушение конфигурации лица, наличие морфологических элементов в виде схем ориентировочной основы действия. Появление язв, трещин, инфильтратов в области слизистой оболочки полости рта и языка - информативный признак как доброкачественных, так и злокачественных процессов. Важно, что авторы рекомендуют верифицировать диагноз непосредственно в день обращения - проводить цитологическую диагностику и по ее результатам выполнять соответствующую терапию. 
Рассмотрены виды нарушений конфигурации лица, острые одонтогенные воспалительные заболевания, такие как острый периодонтит, острый гнойный периостит, флегмоны, аденофлегмоны, фурункулы, карбункулы. В диагностике одонтогенных флегмон отмечено 4 местных признака, встречающихся в различных комбинациях - наличие причинного зуба, выраженности разлитого воспалительного уплотнения (инфильтрата) и окружающего его отёка мягких тканей околочелюстной области, нарушение двигательной функции нижней челюсти от ограничения до невозможности открывать рот, признак болезненного глотания. Описанные отличительные признаки флегмон очень важны для врача-стоматолога на амбулаторном стоматологическом приёме.

В пособии отмечено, что наличие ряда симптомов является признаком различных заболеваний, что и отражено в схеме ориентировочной основы действий: «Методы обследования с целью диагностики заболеваний органов полости рта». В жалобах больного часто превалируют субъективно оцениваемые и наиболее важные с его точки зрения явления, которые, доминируя в физиологическом и психологическом восприятии, могут завуалировать другие сложные заболевания зубочелюстной системы, но протекающие без субъективных для больного ощущений. Важно помнить, что в зубочелюстной системе чаще всего имеется сочетание различных заболеваний и их осложнений.

Описаны все методы исследований (СООД, Приложение 2, 3, 4, 5), которые дают возможность при проведении диагностического процесса фиксировать и правильно интерпретировать данные обследования. Отмечены основные и специфические признаки заболеваний зубочелюстной системы, их классификации, которые основаны на владении врачебного мышления на этапах обследования, особенно при анализе и синтезе полученных субъективных и объективных данных для установления этиологии заболевания, его патогенеза и, наконец, для постановки диагноза и определения метода лечения и врачебной тактики.

В пособии использованы схемы ориентировочной основы действия, такие как «Методы обследования с целью диагностики заболеваний слизистой полости рта, языка, губ», «Диагностические признаки глоссалгии, глоссодинии и глоссита». Схема ориентировочной основы действий по диагностике острых одонтогенных периоститов челюстей, по диагностике травматических повреждений челюстно-лицевой области, «Диагностические признаки флюороза, кариеса и гипоплазии в стадии пятна», «Диагностические признаки эрозивной формы флюороза». При описании математических индексов, применяемых на амбулаторном приёме врачастоматолога, авторы пособия применяли методы доказательной медицины.

Систематизированы и отмечены клинические проявления деформаций зубных рядов и прикуса, где определяют число имеющихся зубов; наличие, топографию и протяженность дефектов в зубных рядах; наличие пломб и их состояние. 
Не менее серьезными являются последствия отсутствия зубов для социального статуса пациентов: нарушения артикуляции и дикции сказываются на коммуникационных способностях пациента, эти нарушения, одновременно с изменениями внешности вследствие утраты зубов и развивающейся атрофии жевательных мышц, могут обусловить изменения психоэмоционального состояния, вплоть до нарушений психики.

Отсутствие зубов является также одной из причин развития специфических осложнений в челюстно-лицевой области, таких как дисфункции височно-нижнечелюстных суставов и соответствующего болевого синдрома.

Основная цель сбора диагностических данных направлена на сохранение здоровья людей.

Использование методов диагностики позволяет установить соответствие тяжести заболевания и степени субъективных ощущений пациента, оценить объективные критерии заболевания и поставить диагноз, выявить и исключить факторы, которые могут способствовать прогрессированию болезни.

Рассмотрены основные направления диагностики, необходимыми элементами которого являются анализ и синтетиз, опирающиеся на данные по изучению больного. Для правильного проведения диагностического процесса необходимо знать и уметь применять на практике все методы исследований, фиксировать и правильно трактовать полученные при этом признаки, симптомы заболеваний, знать основные и специфические признаки заболеваний зубочелюстной системы, классификацию этих заболеваний, владеть особенностями врачебного мышления.

Вопросы взаимоотношений врач - медицинская сестра - больной постоянно находятся в центре внимания общественных интересов и исследований, проводимых в этой области. Нормальное взаимоотношение врача и больного должны сочетать четыре компонента: поддержка, понимание, уважение, сочувствие. От подхода врача к больному зависит успех лечения. Больной должен верить врачу. Это доверие складывается из многих факторов: поведение врача и персонала, состояние кабинета, оборудования, организация рабочего места, соблюдение санитарно-эпидемиологического режима при проведении лечебных манипуляций и т д. Вежливая, приветливая встреча, вызывающая у больного чувство, что его здесь ждут и ему рады, - лучший способ налаживания контакта. Мимика, выражение лица, жесты регистратора подтверждают уверенность больного в правильности выбора «своей клиники» и «своего лечащего врача».

Получение достоверной информации, отражающей в полной мере состояние здоровья пациентов, доступность медицинской помощи, ее качество и другие вопросы организации амбулаторно-поликлинической помощи требуют знания правил ведения первичной медицинской документации. Врачи не всегда оценивают значимость этой проблемы и не фиксируют внимания на основных учетно-оперативных медицинских, юридических документах, используемых в работе. 
Медицинская документация - это документы установленной формы, предназначенные для регистрации результатов лечебных, диагностических, профилактических, реабилитационных, санитарно-гигиенических и других мероприятий. Она позволяет обобщать и анализировать данную информацию. Медицинская документация является учетной и отчетной, ее держателем выступают медицинские учреждения, следовательно, врачи медицинских учреждений несут ответственность за неправильное оформление соответствующих документов.

В заключительной части пособия (Приложение) «Синдромносходные заболевания органов полости рта» рассмотрены дополнительные методы обследования, интерпретация которых даёт возможность при проведении диагностического процесса фиксировать и правильно интерпретировать данные обследования.

Медицинская этика не позволяет оставлять пациента без помощи, если врач знает, что она ему (больному) необходима, чтобы использовать неизбежные негативные последствия в качестве основания для проведения лечения. В то же время со стороны пациента также некорректно допускать заболевания, чтобы потом осуждать результаты лечения или более того возлагать на врача ответственность за будущие расстройства.

Если врач только ставит диагноз, но не проводит лечение, то к его советам нужно относиться с большой осторожностью. Для подтверждения своей квалификации такие коллеги должны сами осуществлять назначенные ими мероприятия и на практике доказывать их эффективность.

Современный врач-стоматолог - это типичный knowledge worker (работник, вооружённый знаниями).

Он может способствовать достижению здоровья полости рта, улучшить эстетические характеристики зубов и лица. Однако он не может пообещать, тем более обеспечить достижение состояния полного телесного, психического и социального благополучия. 


\section{ПРИЛОЖЕНИЕ 10}

10.Европейские цели стоматологического здоровья к 2020 г. (ВОЗ 1999 г.)

\begin{tabular}{|c|c|c|}
\hline Цель & Возраст & Критерии стоматологического здоровья \\
\hline 1. & 6 лет & $\begin{array}{l}\text { 1.1. } 80 \% \text { и более будут здоровы (свободны } \\
\text { от кариеса) } \\
\text { 1.2. Средний - КП временных зубов не бу- } \\
\text { дет превышать } 2,0\end{array}$ \\
\hline 2. & 12 лет & $\begin{array}{l}\text { 2.1. Средняя интенсивность кариеса посто- } \\
\text { янных зубов - КПУ не превысит } 1,5 \text {, где } \\
\text { компонент «К» будет < } 0,5 \\
2.2 \text { Среднее количество секстантов } \\
(\mathrm{CP} 1 \mathrm{TN}) \text { с кодом «0» будет не }<5,5 \\
\end{array}$ \\
\hline 3. & 15 лет & $\begin{array}{l}\text { 3.1. Средняя интенсивность кариеса - КПУ } \\
\text { не превысит } 2,3, \text { где компонент «К» будет } \\
<0,5 \\
3.2 \text {. Не будет удалённых зубов по поводу } \\
\text { кариеса } \\
3.3 \text { Среднее количество секстантов } \\
\text { (CР1TN) с кодом «0» будет не }<5,0\end{array}$ \\
\hline 4. & 18 лет & $\begin{array}{l}\text { 4.1. Не будет удалённых зубов по поводу } \\
\text { кариеса и болезней пародонта } \\
4.2 \text { Среднее количество секстантов } \\
(\mathrm{CP} 1 \mathrm{TN}) \text { с кодом «0» будет не }<4,0\end{array}$ \\
\hline 5. & 35-44 года & 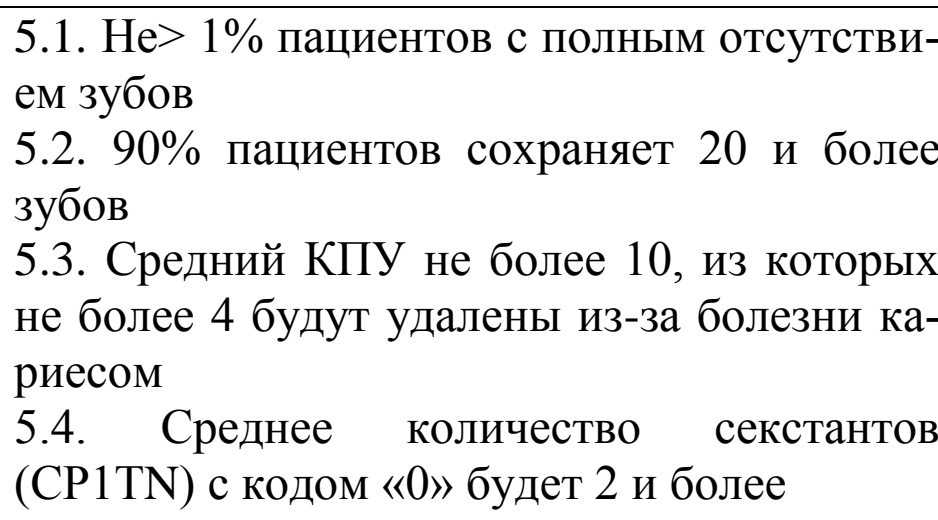 \\
\hline
\end{tabular}




\begin{tabular}{|c|c|c|}
\hline 6. & 65-74 года & $\begin{array}{l}\text { 6.1. Не более } 10 \% \text { пациентов с полным от- } \\
\text { сутствием зубов } \\
6.2 .90 \% \text { пациентов будут иметь функцио- } \\
\text { нально полноценный прикус (естественный } \\
\text { или восстановленный) } \\
6.3 \text {. Среднее количество секстантов } \\
\text { (СР1TN) с глубокими карманами не превы- } \\
\text { сит } 0,5 \text { (код-4). }\end{array}$ \\
\hline
\end{tabular}

ПРИЛОЖЕНИЕ 10.1

Международная классификация стоматологических болезней на основе МКБ - 10 МКБ - С. Третье издание. ВОЗ.1997

КЛАСС ХІ - БОЛЕЗНИ ОРГАНОВ ПИЩЕВАРЕНИЯ

Блок (КО0-К14) - Болезни полости рта, слюнных желез и челюстей. Болезни органов пищеварения

Ко0 Нарушение развития и прорезывания зубов

Исключены: ретенированные и импактные зубы (К01.-)

К00.0 Адентия

К00.00 Частичная адентия (гиподентия) (олигодентия)

К00.01 Полная адентия

К00.09 Адентия неуточненная

К00.01 Сверхкомплектные зубы

Включены: добавочные зубы

Исключены: импактные сверхкомплектные зубы (К01.18)

К00.10 Областей резца и клыка мезиодентия (срединный зуб)

К00.11 Области премоляров

К00.12 Области моляров, дистомолярный зуб, четвертый моляр, парамолярный зуб

К00.19 Сверхкомплектные зубы неуточненные

К00.02 Аномалии размеров и формы зубов

К00.20 Макродентия

К00.21 Микродентия

К00.22 Сращение

К00.23 Слияние [синодентия] и раздвоение [шизодентия]

К00.24 Выпячивание зубов [добавочные окклюзионные бугорки]

Исключена: бугорковая аномалия Карабелли, рассматриваемая как вариант нормы и неподлежащая кодированию

К00.25 Инвагинированный зуб [«зуб в зубе»] [Дилатированная одонтома] аномалия резца, небная борозда (копьевидная конические резцы), лопатообразные резцы, Т-образные резцы

К00.26 Премоляризация

К00.27 Аномальные бугорки и эмалевые жемчужины (адамантома) 
Исключены: выпячивание зубов (добавочные окклюзионные бугорки) (К00.24) бугорковая аномалия Карабелли, рассматриваемая как вариант нормы, неподлежамая кодированию

К00.28 (Бычий зуб) (тауродонтизм) К00.29 Другие неуточненные аномалии размеров и форм зубов

\section{К00.3 Крапчатые зубы}

Исключены: отложения (наросты) на зубах (К03.6) зуб Тернера (К00.46)

К00.30 Эндемическая (флюорозная) крапчатость эмали (флюороз зубов)

К00.31 Неэндомическая крапчатость эмали (нефлюорозное помутнение эмали)

К00.39 Крапчатые зубы неуточненные

К00.4 Нарушения формирования зубов

Исключены: наследственные нарушения структуры зуба (К00.5) резиы Гетченсона (А50.51) крапчатые зубы (К00.3) моляры в виде тутовых ягод (A50.52)

К00.40 Гипоплазия эмали

К00.41Пренатальная гипоплазия эмали

К00.42 Неонатальная гипоплазия эмали

К00.43 Аплазия и гипоплазия цемента

К00.44 Дилацерация (трещины эмали)

К00.45 Одонтодисплазия (региональная одонтодисплазия)

К00.46 Зуб Тернера

К00.48 Другие уточненные нарушения формирования зубов

К00.49 Нарушения формирования зубов неуточненное

К00.5. Наследственные нарушения структуры зуба, не классифицированные в других рубриках

К00.50 Незавершенный амелогенез

К00.51 Незавершенный дентиногенез, изменения в зубах при незавершенном остеогенезе (Q78.0)

Исключены: дисплазия дентина (К00.58) раковинные зубы (К00.58)

К00.52 Незавершенный одонтогенез

К00.58 Другие наследственные нарушения структуры зуба, дисплазия дентина раковинные зубы

К00.59 Наследственные нарушения структуры зуба неуточненные

\section{К00.6 Нарушения прорезывания зубов}

К00.60 Натальные (прорезавшиеся к моменту рождения) зубы

К00.61 Неонатальные (у новорожденного, прорезавшиеся преждевременно) зубы

К00.62 Преждевременное прорезывание (раннее прорезывание)

К00.63 Задержка (персистентная) смены первичных (временных) зубов

К00.64 Позднее прорезывание

К00.65 Преждевременное выпадение первичных (временных) зубов

Исключена: эксфолиаџия зубов (связанная с болезнью окружающих тканей) $($ К08.0X)

К00.68 Другие уточненные нарушения прорезывания зубов 
К00.69 Нарушения прорезывания зубов неуточненные

К00.7 Синдром прорезывания зубов

К00.8 Другие нарушения развития зубов

Включена: выраженная окрашенность зубов БДУ

Исключены: изменения ивета зубов локального происхождения (К03.6, K03.7)

К00.80 Изменения цвета зубов в процессе формирования вследствие несовместимости групп крови

К00.81 Изменение цвета зубов в процессе формирования вследствие врожденного порока биллиарной системы

К00.82 Изменение цвета зубов в процессе формирования вследствие порфирии

К00.83 Изменение цвета зубов в процессе формирования вследствие применения тетрациклина

К00.88 Другие уточненные нарушения развития зубов

К00.9 Нарушение развития зубов неуточненные

К01 Ретенированные и импактные зубы

Исключены: Ретенированные и импактные зубы с неправильным положением их или соседних зубов (К07.3)

К01.0. Ретенированные зубы

Ретенированный зуб - это зуб, изменивший свое положение при прорезывании без препятствия со стороны соседнего зуба

К01.1. Импактные зубы

Импактный зуб - это зуб, изменивший свое положение при прорезывании из-за препятствия со стороны соседнего зуба.

К01.10 Резец верхней челюсти

К01.11 Резец нижней челюсти

К01.12 Клык верхней челюсти

К01.13 Клык нижней челюсти

К01.14 Премоляр верхней челюсти

К01.15 Премоляр нижней челюсти

К01.16 Моляр верхней челюсти

К01.17 Моляр нижней челюсти

К01.18 Сверхкомплектный зуб

К01.19 Импактный зуб неуточненный

К02 Кариес зубов

К02.0 Кариес эмали. Стадия «белого (мелового) пятна» (начальный кариес)

К02.1 Кариес дентина

К02.2 Кариес цемента

К02.3 Приостановившийся кариес зубов

К02.4 Одонтоклазия

Детская меланодентия

Меланодонтоклазия

Исключена: внутренняя и внешняя патологическая резорбция зубов (K03.3) 
К02.8 Другой уточнённый кариес зубов

К02.9 Кариес зубов неуточнённый

К03 Другие болезни твердых тканей зубов

К03.0 Повышенное стирание зубов

К03.00 Окклюзионное

К03.01 Апроксимальное

К03.08 Другое уточненное стирание зубов

К03.08 Стирание зубов неуточненное

К03.1 Сошлифовывание (абразивный износ) зубов

К03.10 Вызванное зубным порошком. Клиновидный дефект БДУ

К03.11 Привычное

К03.12 Профессиональное

К03.13 Традиционное ритуальное

К03.18 Другое уточненное сошлифовывание зубов

К03.19 Сошлифовывание зубов неуточненное

К03.2 Эрозия зубов

К03.20 Профессиональная

К03.21 Обусловленная персистирующей регургитацией или рвотой

К03.22 Обусловленная диетой

К03.23 Обусловленная лекарствами и медикаментами

К03.24 Идиопатическая

К03.28 Другая уточненная эрозия зубов

К03.29 Эрозия зубов неуточненная

К03.3 Патологическая резорбция зубов

К03.30 Внешняя (наружная)

К03.31 Внутренняя (внутренняя гранулема) (розовое пятно)

К03.39 Патологическая резорбция зубов неуточненная

К03.4 Гиперцементоз

Исключен: гипериементоз при болезни Педжета

К03.5 Анкилоз зубов

К03.6 Отложения (наросты) на зубах

Включено: окрашивание зубов БДУ

К03.60 Пигментированный налет черный, зеленый, оранжевый

К03.61 Обусловленные привычкой употреблять табак

К03.62 Обусловленные привычкой жевать бетель

К03.63 Другие обширные мягкие отложения белые отложения (material alba)

К03.64 Наддесневой зубной камень

К03.65 Поддесневой зубной камень

К03.66 Зубной налет

К03.68 Другие уточненные отложения на зубах К03.69 Отложение на зубах неуточненное

К03.7 Изменения цвета твердых тканей зубов после прорезывания

Исключены: отложения (наросты) на зубах (К03.6)

К03.70 Обусловленные наличием металлов и металлических соединений 
К03.71 Обусловленные кровоточивостью пульпы

К03.72 Обусловленные привычкой жевать бетель табак

К03.78 Другие уточненные изменения цвета

К03.79 Изменение цвета неуточненное

К03.8 Другие уточненные болезни твердых тканей зубов

К03.80 Чувствительный дентин

К03.81 Изменения эмали, обусловленные облучением. При необходимости идентифицировать излучение, вызвавшее поражение, используют дополнительный код внешних причин (класс XX)

К03.88 Другие уточненные болезни твердых тканей зубов

К03.9 Болезнь твердых тканей зубов неуточненная

К04 Болезни пульпы и периапикальных тканей

К04.0 Пульпит

К04.00 Начальный (гиперемия)

К04.01 Острый;

К04.02 Гнойный (пульпарный абсцесс);

К04.03 Хронический

К04.04 Хронический язвенный;

К04.05 Хронический гиперпластический;

К04.08 Другой уточненный пульпит;

К04.09 Пульпит неуточненный.

К04.1 Некроз пульпы. Гангрена пульпы

К04.2 Дегенерация пульпы

- дентикли;

- пульпарные кальцификации

- пульпарные камни

К04.3 Неправильное формирование твердых тканей в пульпе.

К04.3x Вторичный или иррегулярный дентин.

Исключены: пульпарные кальцификации (К04.2)

Пульпарные камни (К04.2)

К04.4 Острый апикальный периодонтит пульпарного происхождения

Острый апикальный периодонтит

К04.5 Хронический апикальный периодонтит

Апикальная гранулёма

К04.6 Периапикальный абцесс со свищом

Включены: дентальный, дентоальвеолярный абцесс со свищём

Периодонтальный абиесс пульпарного происхождения

К04.60 Имеющий сообщение (свищ) с верхнечелюстной пазухой

К04.61 Имеющий сообщение (свищ) с носовой полостью

К04.62 Имеющий сообщение (свищ) с полостью рта

К04.63 Имеющий сообщение (свищ) с кожей

К04.69 Периапикальный абцесс со свищом неуточнённый

К04.7 Периапикальный абцесс без свища

Дентальный абцесс

Дентоальвеолярный абцесс 
Периодонтальный абцесс пульпарного происхождения

Периапикальный абцесс без свища

К04.8 Корневая киста

Включена: киста:

апикальная (периодонтальная)

периапикальная

К04.80 Апикальная и боковая

К04.81 Остаточная

К04.82 Воспалительная парадентальная

Исключена: образовавшаяся в прочессе формирования зубов боковая киста периодонтальная (К09.04)

К04.89 Корневая киста неуточнённая

К04.9 Другие и неуточнённые болезни пульпы и периапикальных тканей

К05 Гингивит и болезни пародонта

Включена: болезнь беззубого альвеолярного края

К05.0 Острый гингивит

Исключены: острый перикоронит (К05.22), острый некротизирующий язвенный (фузоспирохетозный) гингивит (гингивит Венсана) (А69.10), гингивостоматит, вызванный вирусом простого герпеса (B00.2X)

К05.00 Острый стрептококковый гингивостоматит

К05.00 Другой уточненный острый гингивит

К05.09 Острый гингивит неуточненный

К05.1 Хронический гингивит

К05.10 Простой маргинальный

К05.11 Гиперпластический

К05.12 Язвенный

Исключен: некротизируюший язвенный гингивит (А69.10)

К05.13 Десквамативный

К05.18 Другой уточненный хронический гингивит

К05.19 Хронический гингивит неуточненный

К05.2 Острый пародонтит

К05.20 Периодонтальный абсцесс (пародонтальный абсцесс) десневого происхождения без свища, периодонтальный абсцесс десневого происхождения, не связанный со свищом

Исключены: острый апикальный периодонтит пульпарного происхождения (К04.4), острый периапикальныи абсиесс пульпарного происхождения (K04.6, K04.7)

К05.21 Периодонтальный абсцесс (парододонтальный абсцесс) десневого происхождения со свищом

Исключены: острый апикальный периодонтит пульпарного происхождения (К04.4), острый периапикальный абсиесс пульпарного происхождения (K04.6,K04.7)

К05.22 Острый перикоронит

К05.28 Другой уточненный острый пародонтит 
К05.29 Острый пародонтит неуточненный

К05.3 Хронический пародонтит

К05.30 Локализованный

К05.31 Генерализованный

К05.32 Хронический перикоронит

К05.33 Утолщенный фолликул (гипертрофия сосочка)

К05.38 Другой уточненный хронический пародонтит

К05.39 Хронический пародонтит неуточненный

К05.4 Пародонтоз. Юношеский (ювенильный) пародонтоз

К05.5 Другие болезни пародонта

К06 Другие изменения десны и беззубого альвеолярного края

Исключены: атрофия беззубого альвеолярного края (К08.2), гингивит (K05.0, K05.1)

К06.0 Рецессия десны

Включены: Постинфекционная, постоперационная

К06.00 Локальная

К06.01 Генерализованная

К06.09 Рецессия десны неуточненная

К06.1 Гипертрофия десны

Включена: бугристость

К06.10 Фиброматоз десны

К06.18 Другая уточненная гипертрофия десны

К06.19 Гипертрофия десны неуточненная

К06.2 Поражения десны беззубого альвеолярного края, обусловленного травмой

К06.20 Обусловленная травматической окклюзией

К06.21 Обусловленная чисткой зубов щеткой

К06.22 Фрикционный (функциональный) кератоз

К06.23 Гиперплазия вследствие раздражения (гиперплазия, связанная с ношением съемного протеза)

К06.28 Другие уточненные поражения десны и беззубого альвеолярного края, обусловленные травмой

К06.29 Неуточненные поражения десны и беззубого альвеолярного края, обусловленные травмой

К06.8 Другие уточненные изменения десны и беззубого альвеолярного края

К06.80 Киста десны взрослых

Исключена: киста десны новорожденных (К09.82)

К06.81 Гигантоклеточная периферическая гранулема (гигантоклеточный эпулис)

К06.82 Фиброзный эпулис

К06.83 Пиогенная гранулема

Исключена: пиогенная гранулема других локализаџий, нежели десна или беззубый альвеолярный край (К13.40)

К06.84 Атрофия гребня частичная 
К06.88 Другие изменения

К06.9 Изменения десны и беззубого альвеолярного края неуточненные К07 Челюстно-лицевые аномалии (включая аномалии прикуса) К07.0 Основные аномалии размеров челюстей

Исключены: акромегалия (Е22.0), атрофия или гипертрофия половиньл лииа (Q67.4), синдром Робина (Q87.0) односторонняя мыщелковая гиперплазия (К10.81), односторонняя мыщелковая гипоплазия (К10.82)

К07.00 Макрогнатия верхней челюсти (гиперплазия верхней челюсти)

К07.01 Макрогнатия нижней челюсти (гиперплазия нижней челюсти)

К07.02 Макрогнатия обеих челюстей

К07.03 Микрогнатия верхней челюсти (гипоплазия верхней челюсти)

К07.04 Микрогнатия нижней челюсти (гипоплазия нижней челюсти)

К07.05 Микрогнатия обеих челюстей

К07.08 Другие уточненные аномалии размеров челюстей

К07.09 Аномалия размеров челюстей неуточненная

К07.1 Аномалии челюстно-черепных соотношений

К07.10 Асимметрия

Исключень: атрофия половины лица (Q67.40) гипертрофия половиныл лица (Q67.41) односторонняя мыщелковая гиперплазия (К10.81) односторонняя мыцеелковая гипоплазия (К10.82)

К07.11 Прогнатия нижней челюсти

К07.12 Прогнатия верхней челюсти

К07.13 Ретрогнатия нижней челюсти

К07.14 Ретрогнатия верхней челюсти

К07.18 Другие уточненные аномалии челюстно-черепных соотношений

К07.19 Аномалия челюстно-лицевых соотношений неуточненная

К07.2 Аномалии соотношений зубных дуг

К07.20 Дистальный прикус

К07.21 Мезиальный прикус

К07.22 Чрезмерно глубокий горизонтальный прикус (горизонтальное перекрытие)

К07.23 Чрезмерно глубокий вертикальный прикус (вертикальное перекрытие)

К07.24 Открытый прикус

К07.25 Перекрестный прикус (передний, задний)

К07.26 Смещение зубных дуг от средней линии

К07.27 Заднеязычный прикус нижних зубов

К07.28 Другие уточненные аномалии соотношений зубных дуг

К07.29 Аномалии соотношений зубных дуг неуточненные

К07.3 Аномалии положения зубов

К07.30 Скученность, черепицеобразное перекрытие

К07.31 Смещение

К07.32 Поворот

К07.33 Нарушение межзубных промежутков диастемы

К07.34 Транспозиция 
К07.35 Ретенированные или импактные зубы с неправильным положением их или соседних зубов

Исключены: ретенированные или импактные зубы с нормальным положением их или соседних зубов (К01.0, К01.1)

К07.38 Другие уточненные аномалии положения зубов

К07.39 Аномалии положения зубов неуточненные

К07.4 Аномалии прикуса неуточненные

К07.5 Челюстно-лицевые аномалии функционального происхождения

Исключен: бруксизм (скрежетание зубами) (F45.82)

К07.50 Неправильное смыкание челюстей

К07.51 Нарушение прикуса вследствие нарушения глотания

К07.54 Нарушение прикуса вследствие ротового дыхания

К07.55 Нарушение прикуса вследствие сосания языка, губ или пальца

К07.58 Другие уточненные челюстно-лицевые аномалии функционального происхождения

К07.59 Неуточненные

К07.6 Болезни височно-нижнечелюстного сустава

К07.60 Синдром болевой дисфункции височно-нижнечелюстного сустава (синдром Костена)

К07.61 «Щелкающая» челюсть

К07.62 Рецидивирующий вывих и подвывих височно-нижнечелюстного сустава

К07.63 Боль в височно-нижнечелюстном суставе, не классифицированная в других областях

К07.64 Тугоподвижность височно-нижнечелюстного сустава, не классифицированная в других рубриках

К07.65 Остеофит височно-нижнечелюсного сустава

К07.68 Другие уточнённые болезни височно-нижнечелюстного сустава

К07.69 Болезнь височно-нижнечелюстного сустава неуточнённая

К08 Другие изменения зубов и их опорного аппарата

К08.0 Эксфолиация зубов вследствие системных нарушений

Исключена: адентия (К00.0)

К08.0 Эксфолиация зубов (связанная с болезнью окружающих тканей, включая системные нарушения, например, при токсическом действии ртути (Т56.1) или гипофосфатазии (Е83.3))

Исключено: преждевременное выпадение первичных (временных) зубов (K00.65)

К08.1 Потеря зубов вследствие несчастного случая, удаления или локализованного пародонтита

Исключен: Вывих зуба (S03.2)

К08.2 Атрофия беззубого альвеолярного края

К08.3 Оставшийся корень зуба

К08.8 Другие уточненные изменения зубов и их опорного аппарата

К08.80 Зубная боль БДУ

К08.81 Неправильная форма альвеолярного отростка 
К08.82 Гипертрофия альвеолярного края БДУ

К08.88 Другие изменения

Ко8.9 Изменения зубов и их опорного аппарата неуточненная К09 Кисты области рта не классифицированные в других рубриках

Исключены: корневая киста (К04.8), мукочеле слюнной железы (К11.6)

К09.0 Кисты, образовавшиеся в процессе формирования зубов

К09.00 Киста при прорезывании зубов

К09.01 Киста десны

К09.02 Роговая (первична) киста

К09.03 Фолликулярная (одонтогенная) киста

К09.04 Боковая периодонтальная киста

К09.08 Другие уточненные одонтогенные кисты, образовавшиеся в процессе формирования зубов

К09.09 Одонтогенная киста, образовавшаяся в процессе формирования зубов неуточненная

\section{К09.1 Ростовые (неодонтогенные) кисты области рта}

Включены: «щелевые» кисты

К09.10 Глобуломаксиллярная (верхнечелюстной пазухи) киста

К09.11 Средненебная киста

К09.12 Носонебная (резцового канала) киста

К09.13 Небная сосочковая киста

К09.18 Другие уточненные ростовые кисты области рта

К09.19 Ростовая киста области рта неуточненная

К09.2 Другие кисты челюстей

Исключены: скрытая костная киста челюсти (К10.02), киста Стафне (K10.02)

К09.20 Аневризматическая костная киста

К09.21 Единичная костная (травматическая) (гемморагическая) киста

К09.22 Эпителиальные кисты челюсти, неидентифицированные одонтогенные или неодонтогенные

К09.28 Другие уточненные кисты челюсти

К09.29 Киста челюсти неуточненная

К09.8 Другие уточненные кисты области рта, не классифицированные в других рубриках

К09.80 Дермоидная киста

К09.81 Эпидермоидная киста

К09.82 Киста десны новорожденных

Исключена: киста десны у взросльх (К06.80)

К09.83 Киста неба новорожденных жемчужина Эпштейна

К09.84 Носоальвеолярная (носогубная) киста

К09.85 Лимфоэпителиальная киста

К09.88 Другие уточненные кисты области рта

К09.9 Киста области рта неуточненная

К10 Другие болезни челюстей

К10.0 Нарушения развития челюстей 
К10.00 Торус нижней челюсти

К10.01 Торус твердого неба

К10.02 Скрытая костная киста

дефект развития кости в нижней челюсти

киста Стафне

статическая костная киста

К10.08 Другие уточненные нарушения развития челюстей

К10.09 Нарушение развития челюстей неуточненное

К10.1 Гигантоклеточная гранулема центральная

Гигантоклеточная гранулема БДУ

Исключена: периферическая гигантоклеточная гранулема (К06.81)

К10.2 Воспалительные заболевания челюстей

При необходимости идентифицировать излучение, вызвавшее поражение, используют дополнительный код внешних причин (класс XX)

К 10.20 Остеит челюсти

Исключены: альвеолярный остеит (К10.3) сухая лунка (К10.3)

К10.21 Остеомиелит челюсти

Исключен неонатальный остеомиелит верхней

челюсти [неонатальный максиллит] (К10.24)

К10.22 Периостит челюсти

К10.23 Хронический периостит челюсти

гиалиновая микроангиопатия пульсирующая гранулема

К10.24 Неонатальный остеомиелит верхней челюсти

[неонатальный максиллит]

К10.25 Секвестр

К10.26 Радиационный остеонекроз

К10.28 Другие уточненные воспалительные заболевания челюстей

К10.29 Воспалительное заболевание челюстей неуточненное

К10.3 Альвеолит челюстей

К10.3 Альвеолярный остеит

К10.3Сухая лунка

К10.8 Другие уточненные болезни челюстей

Исключена: полиостозная фиброзная дисплазия (Q78.1)

К10.80 Херувизм 1

К10.81 Односторонняя гиперплазия мыщелкового отростка нижней челюсти

К10.82 Односторонняя гиперплазия мыщелкового отростка нижней челюсти

К10.83 Фиброзная дисплазия челюсти

К10.88 Другие уточненные болезни челюстей

экзостоз челюсти

К10.9 Болезнь челюстей неуточненная

К11 Болезни слюнных желез

Исключены: опухоли слюнных желез (C07.—, C08.—, D10.-, D11.-

К11.0 Атрофия слюнной железы 
К11.1 Гипертрофия слюнной железы

К11.2 Сиалоаденит

Исключены: эпидемический паротит (В26.-) увеопаротидная лихорадка [болезнь Герфордта] (D86.8)

К11.3 Абсцесс слюнной железы

К11.4 Свищ слюнной железы

Исключен: врожденный свищ слюнной железы (Q38.43)

К11.5 Сиалолитиаз

Камни в слюнном протоке

К11.6 Мукоцеле слюнной железы

Ранула

К11.60 Слизистая ретенционная киста

К11.61 Слизистая киста с экссудатом

К11.69 Мукоцеле слюнной железы неуточненное

К11.7 Нарушения секреции слюнных желез

Исключены: сухость полости рта БДУ (R68.2)

синдром сухости [синдром Шегрена] (M35.0)

К11.70 Гипосекреция

К11.71 Ксеростомия

К11.72 Гиперсекреция [птиализм]

К11.78 Другие уточненные нарушения секреции слюнных желез

К11.79 Нарушение секреции слюнных желез неуточненное

К11.8 Другие болезни слюнных желез

Исключен: синдром сухости [синдром Шегрена] (М35.0)

К11.80 Доброкачественное лимфоэпителиальное поражение слюнной железы

К11.81 Болезнь Микулича

К11.82 Стеноз [сужение] слюнного протока

К11.83 Сиалэктазия

К11.84 Сиалоз

К11.85 Некротизирующая сиалометаплазия

К11.88 Другие уточненные болезни слюнных желез

К11.9 Болезнь слюнной железы неуточненная

Сиалоаденопатия БДУ

К12 Стоматит и родственные поражения

Исключена: очаговая эпителиальная гиперплазия (В07.X2)

- герпетическая ангина (B08.5X)

• гнойный вегетирующий стоматит (L08.0X)

стоматит:

• острый гангренозный (А69.0)

- аллергический (L23.0)

• кандидозный (B37.0)

• контактный (К12.14)

- вызванный вирусом Коксаки, БДУ (В34.1)

• эпизоотический ящур (B08.8) 
- фузоспирохетозный (А69.0)

- медикаментозный (Т36-Т50)

- микотический (В37.0)

• никотиновый (К13.24)

• везикулярный с экзантемой (В08.4)

- стрептококковый гингивостоматит (К05.00)

- болезнь, вызванная вирусом везикулярного стоматита [лихорадка Индианы] (А93.8X)

\section{К12.0 Рецидивирующие афты полости рта}

К12.00 Рецидивирующие (малые) афты афтозный стоматит

язвенное поражение [Canker sore]

афты Микулича

малые афты

рецидивирующие афтозные язвы

К12.01 Рецидивирующий слизисто-некротический периаденит

рубцующийся афтозный стоматит

большие афты

афты Саттона

К12.02 Герпетиформный стоматит [герпетиформная сыпь]

Исключены: герпетиформный дерматит (L13.0X)

герпетический гингивостоматит (B00.2X)

К12.03 Афты Беднара

К12.04 Травматическое изъязвление

Исключено: травматическое изъязвление языка (К14.01)

изъязвление языка БДУ (К14.09)

К12.08 Другие уточненные рецидивирующие афты полости рта

К12.09 Рецидивирующие афты полости рта неуточненные

К12.1 Другие формы стоматита

К12.10 Стоматит артефициальный

К12.11 "Географический" стоматит

Исключен: "географический" язык (КИЛ)

К12.12 Стоматит, связанный с ношением зубного протеза

Исключены: кандидозный стоматит, связанный с ношением зубного протеза (В37.03), травматическое изъязвление, связанное с ношением зубного протеза (К12.04)

К12.13 Папиллярная гиперплазия неба

К12.14 Контактный стоматит

стоматит "ватного валика"

К12.18 Другие уточненные формы стоматита

К12.19 Стоматит неуточненный

К12.2 Флегмона и абсцесс области рта

Флегмона

Абсцесс подчелюстной области 
Исключены: абсцесс:

- периапикальный (К04.6-К04.7)

- периодонтальный (К05.21)

- перитонзиллярный (J36)

- слюнной железы (К11.3)

- языка (К14.00)

К13 Другие болезни губ и слизистой оболочки полости

Включены: изменения эпителия языка

Исключены: некоторые изменения десны и беззубого альвеолярного края (К05-К06), кисты области рта (К09.- ), болезни языка (К14.-) ,стоматит и родственные поражения (К12.- )

К 13.0 Болезни губ

Исключены: актинический хейлит(L56/8X) арибофлавиноз (E53.0)

К13.00 Ангулярный хейлит, ангулярный хейлоз, трещина спайки губ (заеда) НКДР

Исключена: трещина спайки губ (заеда) в следствие:

- кандидоза

• недостаточности рибофлавина (Е53.0)

К13.01 Хейлит гландулярный апостематозный

К13.02 Хейлит эксфолиативный

К13.03 Хейлит БДУ

К13.04 Хейлодиния

К13.08 Другие уточненные болезни губ

К13.09 Болезнь губ неуточненная

К13.1 Прикусывание щеки и губ

К13.22 Лейкоплакия и другие изменения эпителия полости рта, включая язык

2 Поражения (такие, как лейкоплакия, эритроплакия) без указания на тяжелую дисплазию представлены в данном разделе; при этом можно использовать следующие шестизначные подрубрики:

0 - без выявления дисплазии (или степень 0)

1 - незначительная (легкая) дисплазия (или степень 1)

Исключены: кандидозная лейкоплакия (В37.02)

очаговая эпителиальная гиперплазия (В07.X2)

фрикционный кератоз (К06.22)

функциональный кератоз (К06.22)

волосатая лейкоплакия (К13.3)

К13.20 Лейкоплакия идиопатическая

К13.21 Лейкоплакия, связанная с употреблением табака

Исключены: никотиновый лейкокератоз неба (К13.24)

небо курильщика (К13.24)

К13.22 Эритроплакия

К13.23 Лейкедема 
К13.24 Небо курильщика [никотиновый лейкокератоз неба] [никотиновый стоматит]

К13.28 Другие изменения эпителия

К13.29 Неуточненные изменения эпителия лейкоплакия БДУ

К13.3 Волосатая лейкоплакия

К13.4 Гранулема и гранулемоподобные поражения слизистой оболочки полости рта

К13.40 Пиогенная гранулема

Исключена: пиогенная гранулема десны (К06.83)

К13.41 Эозинофильная гранулема слизистой оболочки полости рта

Исключены: эозинофильная гранулема кости (D76.00)

гистиоцитоз X (D76.- )

K13.42 Веррукозная ксантома [гистиоцитоз Y]

К13.48 Другие уточненные гранулемы и гранулемоподобные поражения слизистой оболочки полости рта

К13.49 Гранулема и гранулемоподобные поражения слизистой оболочки полости рта неуточненные

К13.5 Подслизистый фиброз полости рта

К13.6 Гиперплазия слизистой оболочки полости рта вследствие раздражения

Исключена: гиперплазия беззубого альвеолярного края вследствие раздражения [гиперплазия, связанная с ношением съемного протеза] (К06.23)

К13.7 Другие и неуточненные поражения слизистой оболочки полости рта

К13.70 Избыточная меланиновая пигментация

- меланоплакия

- меланоз курильщика

К13.71 Свищ полости рта

Исключен: ороантральный свищ (Т81.8)

К13.72 Добровольная татуировка

Исключена: амальгамовая пигментация (Т81.50)

К13.73 Очаговый муциноз полости рта

К13.78 Другие уточненные поражения слизистой оболочки полости рта белая линия

К13.79 Поражение слизистой оболочки полости рта неуточненное

К14 Болезни языка

Исключены: эритроплакия языка (К13.22)

- очаговая эпителиальная гиперплазия (B07.X2)

- волосатая лейкоплакия (К13.3)

- лейкодема и лейкоплакия языка (К13.2)

- макроглоссия (врожденная) (Q38.2Х)

- подслизистый фиброз языка (К13.5)

К14.0 Глоссит

Исключен: атрофический глоссит (К14.42) 
К14.00 Абсцесс языка

К14.01 Травматическое изъязвление языка

К14.08 Другие уточненные глосситы

К14.09 Глоссит неуточненный изъязвление языка БДУ

К14.1 "Географический" язык

- Доброкачественный мигрирующий глоссит

- Эксфолиативный глоссит

\section{К14.2 Срединный ромбовидный глоссит}

К14.3 Гипертрофия сосочков языка

К14.30 Обложенный язык

К14.31 "Волосатый" язык

• черный "волосатый" язык

- черный "ворсинчатый" язык [lingua villosa nigra]

Исключены: волосатая лейкоплакия (К13.3)

"волосатый" язык вследствие приема антибиотиков (К14.38)

К14.32 Гипертрофия листовидных сосочков

К14.38 Другая уточненная гипертрофия сосочков языка

"волосатый" язык вследствие приема антибиотиков

К14.39 Гипертрофия сосочков языка неуточненная

К14.4 Атрофия сосочков языка

К14.40 Вызванная привычками очищать язык

К14.41 Вызванная системным нарушением

К14.42 Атрофический глоссит БДУ

К14.48 Другая уточненная атрофия сосочков языка

К14.49 Атрофия сосочков языка неуточненная

К14.5 Складчатый язык

- Морщинистый язык

- Бороздчатый язык

- Расщепленный язык

Исключен: расщепленный язык врожденный (Q38.33)

К14.6 Глоссодиния

Исключены: нарушения вкусовой чувствительности (R43.-)

К14.60 Глоссопироз [жжение в языке]

К14.61 Глоссодиния [боль в языке]

К14.68 Другая уточненная глоссодиния

К14.69 Глоссодиния неуточненная

К14.8 Другие болезни языка

К14.80 Зубчатый язык [язык с отпечатками зубов]

К14.81 Гипертрофия языка

гемигипертрофия языка

Исключена: макроглоссия (врожденная) (Q38.2Х)

К14.82 Атрофия языка

гемиатрофия языка

Исключена: атрофия сосочков языка (К14.4)

К14.88 Другие уточненные болезни языка 
болезни язычной миндалины

К14.9 Болезнь языка неуточненная

Неинфекционный энтерит и колит

К50 Болезнь Крона [регионарный энтерит]

К50.8Х Проявления в полости рта

Болезни костно-мышечной системы и соединительной ткани

Инфекционные артропатии

М00 Пиогенный артрит

M00.vx Височно-нижнечелюстного сустава

М02 Реактивные артропатии

М02.3 Болезнь Рейтера

М02.3x Височно-нижнечелюстного сустава

Воспалительные полиартропатии

М05 Серопозитивный ревматоидный артрит

Включён: синдром Фелти

M05.vx Височно-нижнечелюстного сустава

М06 Другие ревматоидные артриты

M06.vx Височно-нижнечелюстного сустава

М08 Юношеский [ювенильный] артрит

Включена: болезнь Стилла

M08.vx Височно-нижнечелюстного сустава

М12 Другие специфические артропатии

12.2 Ворсинчато-узелковый [виллонодулярный] синовит (пигментный)

М12.2x Височно-нижнечелюстного сустава

M12.5 Травматическая артропатия

М12.5x Височно-нижнечелюстного сустава

М13 Другие артриты

М13.9 Артрит неуточнённый

M13.9x Височно-нижнечелюстного сустава

АРТРО3Ы

М15 Полиартроз

M15.vx Височно-нижнечелюстного сустава

М19 Другие артрозы

Включены: остоартрит, остеоартоз

M19.0 Первичный артроз других суставов

М19.0Х Височно-нижнечелюстного сустава

Травмы головы

Включены: травмыл:

Уxa

Глаза

Лицуа (любая часть)

Десньл (десни, альвеолярного гребня)

Челюсти

Области височно-нижнечелюстного сустава 
Полости рта

Нёба

Окологлазничной части

Волосистой части головь

Языка

Зуба

S00.5 Поверхностная травма губы и полости рта

S00.50 Поверхностная травма внутренней поверхности щеки

S00.51 Поверхностная травма других областей рта (включая язык)

S00.52 Поверхностная травма губы

S00.59 Поверхностная травма губы и полости рта неуточнённая

S01.4 Открытая рана губы и полости рта

Исключены: открытая рана щеки(S01.40)

Вывих зуба(S03.2)

Перелом зуба(S02.5)

S01.50 Открытая рана рта (включая язык)

S01.51 Открытая рана губы

S01.59 Открытая рана губы и полости рта неуточнённая

S02.4 Перелом скуловой кости и верхней челюсти

S02.40 Перелом альвеолярного отростка верхней челюсти

S02.41 Перелом скуловой кости (дуги)

S02.42 Перелом верхней челюсти

S02.47 Множественные переломы скуловой кости и верхней челюсти S02.5Перелом зуба

Включён: первичных (молочных) и постоянных зубов

$\mathrm{S} 02.50$ Перелом только эмали зуба, откол эмали

S02.51 Перелом коронки зуба без повреждения пульпы

S02.52 Перелом коронки зуба с повреждением пульпы

S02.53 Перелом корня зуба

S02.54 52 Перелом коронки и корня зуба

S02.57 Множественные переломы зубов

S02.59 Перелом зуба неуточнённый

S02.6 Перелом нижней челюсти

S02.60 Перелом альвеолярного отростка

S02.61 Перелом тела челюсти

S02.62 Перелом мыщелкового отростка

S02.63 Перелом венечного отростка

S02.64 Перелом ветви

S02.65 Перелом симфиза

S02.66 Перелом угла

S02.67 Множественные переломы нижней челюсти

S02.69 Перелом нижней челюсти неуточнённой локализации

S03 Вывих, растяжение и перенапряжение суставов и связок головы S03.0 Вывих челюсти 
Исключён: текущий случай вывиха височно-нижнечелюстного сустава (K07.62)

03.2 Вывих зуба

03.20 Люксация зуба

03.21Интрузия или экструзия зуба

03.22 Вывих зуба (экзартикуляция)

04 Травма черепных нервов

04.3Травма тройничного нерва

5-го черепного нерва

04.5Травма лицевого нерва

7-го черепного нерва

04.8 Травма других черепных нервов

04.80 Травма языкоглоточного нерва (9-го черепного нерва)

04.81 Травма подъязычного нерва (12-черепного нерва)

Последствия проникновения инородного тела через естественные отверстия

Т18.0 Инородное тело во рту

Термические и химические ожоги наружных поверхностей тела, уточнённые по их локализации

Т28.0 Термический ожог рта и глотки

Т28.5 Химический ожог рта и глотки

Отравления лекарственными средствами, медикаментами и биологическими веществами

T49 Отравления препаратами местного действия, влияющими преимущественно на кожу и слизистые оболочки, и средствами, используемыми в офтальмологической, отоларингологической и стоматологической практике

T49.7 Стоматологическими препаратами, применяемыми местно

Токсическое действие веществ, преимущественно немедицинского назначения

T57 Токсическое действие других неорганических веществ

T57.0 Мышьяка и его соединений

Внешние причины заболеваемости и смертности

Преднамеренное самоповреждение

Х62 Преднамеренное самоотравление и воздействие наркотиками и психодислептиками (галлюциногенами), не классифицированные в других рубриках

X62VX Кокаином, проявление в полости рта

X77 Преднамеренное самоповреждение паром, горячими испарениями и горячими предметами

X11.VX Проявления в полости рта

Осложнения терапевтических и хирургических вмешательств

Лекарственные средства, медикаменты и биологические вещества, являющиеся причиной неблагоприятных реакций при терапевтическом лечении 
(Y40,Y41, Y42, Y43, Y45, Y46,Y48, Y49,Y52,Y56) проявления в полости рта

\section{Приложение 10.2. Рентгенодиагностика заболеваний органов полости рта}

1. Интерпретация ортопантограмм, томограмм, сиалографии, пантомографии, прицельный $\mathrm{Rg}$ - снимок.

При обследовании обращают внимание на:

1) пороки развития твердых тканей зуба

2) оценку коронковой части; коронка соответствует (указать анатомическое название зуба)

- интактна

- покрыта искусственной коронкой

- реставрирована

- имеется кариозная полость на (указать поверхность), (не) сообщающаяся с полостью зуба

- разрушена на $1 / 3 ; 1 / 2 ; 2 / 3$; до уровня десны; ниже уровня десны

3) полсть зуба

- повторяет контуры коронки

- уменьшена: сужена в области (указать), за счет заместительного дентина

- имеется дентикль (свободный или пристеночный), какой объем полости занимает

- в полости зуба пломбировочный материал

- $\quad$ в полости зуба головка штифта

- в полости зуба перфорация в области: а) дна; б) боковой стенки; на каком уровне

4) соотношение коронки к корню зуба

5) корень зуба

- $\quad$ количество (если более одного, то каждый описать отдельно)

- степень сформированности, резорбции. Форма: а) прямой, б) изогнутый (в какой части корня: верхняя, средняя, коронковая и в каком направлении)

- линия перелома: а) в какой части корня: верхняя, средняя, коронковая; б) направление перелома 
- перфорация: в какой части корня (верхняя, средняя, коронковая)

6) корневой канал

- на каком протяжении просматривается

- ширина

- искривление: в какой части

- при наличии пломбировочного материала: а) протяженность пломбирования (на 1/3; 1/2; 2/34 полностью до верхушки; выведен за верхушку); б) плотность пломбирования (гомогенно; негомогенно (указать, в какой части инородное тело:

- а) инструмент (в какой части); б) штифт; периодонта и кортикальной пластинки на каком протяжении просматривается)

- изменение размера периодонтальной щели (расширена, облитерирована)

- разрушение кортикальной пластинки (участок)

7) форма корня и расстояние между ними

- состояние периодонта и кортикальной пластинки

- изменение размера периодонтальной щели (расширена, облитерирована)

- разрушение кортикальной пластинки (участок)

8) резорбция корней

9) наличие зубного камня

10) близость синуса

11) изменение альвеолярной кости: структура межальвеолярных перегородок, их форма и высота, тип резорбции, наличие костных карманов и кратеров, вовлечение фуркаций, присутствие кортикального слоя, степень минерализации губчатого вещества

12) костная ткань альвеолярных отростков челюстей

- не изменена

- очаги: а) деструкции; б) остеопороза; в) остеосклероза

- указать расположение по отношению к частям корня контуры: a) четкие (форма, размер контуров); б) нечеткие

13) межальвеолярные перегородки

- высота по отношению к шейке зуба (на уровне; $1 / 3 ; 1 / 2 ;>1 / 2$ )

- форма (треугольная, овальная, трапециевидная, прямоугольная)

- кортикальная пластинка (просматривается на всем протяжении; не просматривается; склерозирована)

- изменение костной ткани: остеопороза расположение, размеры очага); резорбция (вертикальная, горизонтальная; остеосклероз (расположение, размеры очага)

14) состояние максимальных контактов.

15) качество эндодонтического лечения

16) отношение корней зубов к верхнечелюстной пазухе

1 гр.- дно пазухи небный корень - 17, 16. 27, 24, 25, 14.15

2 гр. - 0-1,9 мм небный корень - 17.16, 26, 24, 25, 14, 15 
3 гр. $-2-3$ мм

4 гр. - 4-7 мм - щечные корни премоляров

5 гр.- 7 мм - щечные корни премоляров и моляров.

Ортопантомограмма

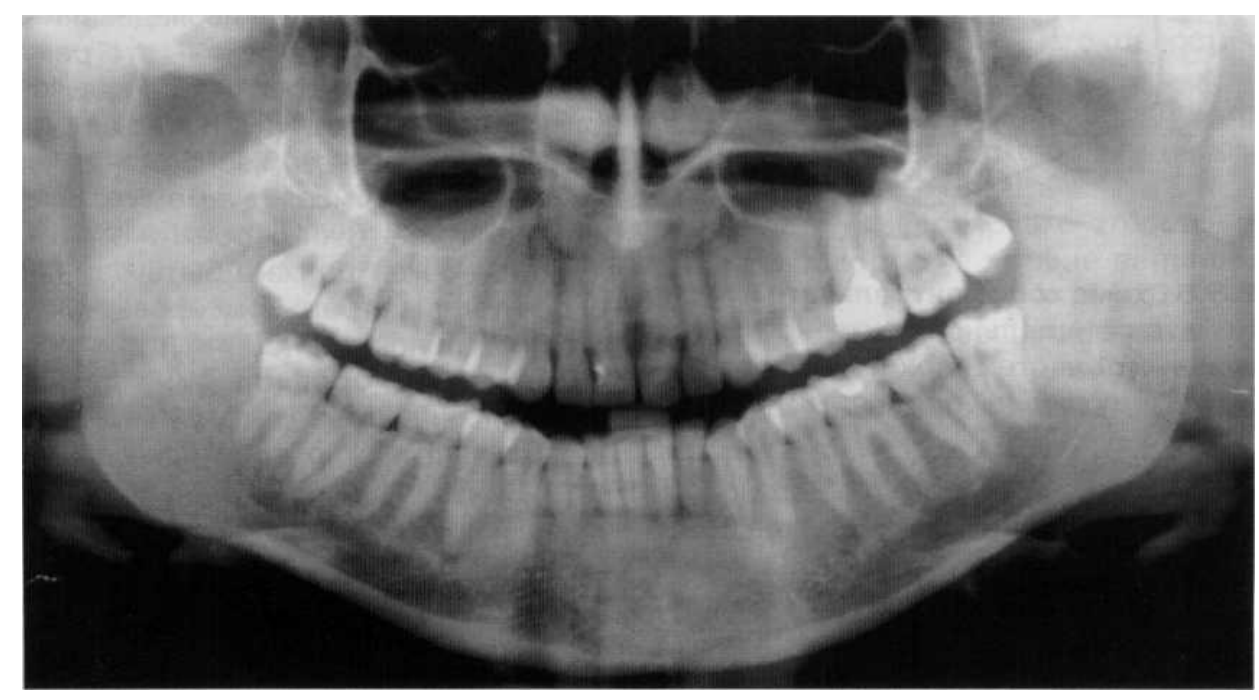

Периодонтит - воспаление тканей периодонта. Гранулирующий периодонтит представляет собой активную форму воспаления, характеризующуюся частыми обострениями. При гранулирующем периодонтите на внутриротовых рентгенограммах (независимо от степени обострения) в кости у верхушки корня зуба различают участок резорбции костной ткани с неровными и нечеткими контурами. Иногда обнаруживается частичная резорбция корня зуба. Деструкция костной ткани может распространяться на альвеолы соседних зубов. Периодонтит многокорневых зубов приводит к резорбции межкорневой костной перегородки. При этом на рентгенограммах корни зубов видны на фоне участка остеолиза костной ткани без четких границ. Хронический периодонтит центральных резцов нижней челюсти, особенно посттравматический, сопровождается разрежением кости вокруг их корней и по размерам и форме напоминает околокорневую кисту. Окончательный диагноз устанавливается после проведенного патогистологического исследования удаленных тканей.

Гранулематозный периодонтит (гранулема) длительное время протекает бессимптомно. На внутриротовых рентгеновских снимках у верхушки корня зуба обнаруживается очаг деструкции округлой формы с четкими ровными контурами. Верхушки корней зубов, обращенных в гранулему, нередко резорбированы. Различают следующие виды гранулем: межкорневые, апикальные (верхушечные), апиколатеральные и латеральные (боковые).

Фиброзный периодонтит по существу является исходом в рубец острого воспалительного процесса. На рентгенограмме периодонтальная щель у пораженного зуба на большом протяжении расширена, местами суживается. Если периодонтит в результате воспаления подвергся оссификации, периодонтальная щель на рентгенограмме отсутствует. 
Периостит. Обострение хронического периодонтита приводит к возникновению острого периостита челюстей. По рентгенологическим признакам острый периостит неотличим от периодонтита, а при хроническом течении может давать рентгенологические изменения. На нижней челюсти возникает муфтообразное плотное малоболезненное утолщение. Поверхность ее гладкая, границы нечеткие. На рентгенограммах вприкус обнаруживается мягкотканная тень инфильтрированной надкостницы. Хронический оссифицирующий периостит выявляется по наружной поверхности нижней челюсти в виде линейной тени или полусферического костного образования, уступающего по интенсивности структуре кортикального вещества челюсти. Рентгенологически характеризуется очагом остеопороза костной ткани с довольно четкими границами, что напоминает радикулярную кисту, но в отличие от нее периодонтальная щель зубов, расположенных в зоне поражения, не изменена.

Одонтогенный остеомиелит. Явления деструкции отчетливо не выражены при остром одонтогенном остеомиелите, поэтому рентгенологически острый одонтогенный остеомиелит челюсти отличить от периостита невозможно. Некроз кости наступает на 3-4-е сутки, первые признаки поражения костной ткани на рентгенограммах можно обнаружить только к концу 2-3-й недели. Появляются очаги остеолиза и некроза. В подострую фазу постепенно вокруг них возникает зона склеротического отграничения, отчетливее выраженная в нижней челюсти. В верхней челюсти спустя 5-6 недель, а в нижней - 6-7 недель рентгенологически отчетливо определяются полости, содержащие костные секвестры. Края секвестров неровные, зазубренные. Между ними и жизнеспособной костной тканью выявляется зона просветления, обусловленная гноем и грануляциями. В хроническую фазу по мере развития склероза формируются секвестральные полости. Вокруг них на нижней челюсти, в результате поднадкостничного костеобразования, формируется секвестральная капсула, отчетливо различимая на рентгенограмме. На верхней челюсти секвестральная капсула не образуется. Регенерация кости выражена значительно слабее, чем на нижней челюсти.

Хронический одонтогенный остеомиелит после удаления отторгнувшихся секвестров завершается репаративными процессами. После секвестрэктомии рентгенологический контроль необходим для определения эффективности хирургического лечения и выявления регенерации кости.

Посттравматический остеомиелит. Ранние признаки посттравматического остеомиелита могут быть обнаружены через 8-10 дней от начала клинического проявления (Н.А. Рабухина, 1974). Первый симптом, который настораживает врача хирурга-стоматолога - это отсутствие тенденции к сужению линии перелома и даже, напротив, увеличение ее. Контуры костных фрагментов становятся неровными и приобретают нечеткость границ. При прогрессировании процесса в краевых отделах отломков появляются очаги разрушения костной ткани, которые вначале имеют вид зон пятнистого остеопороза, а затем сливаются и превращаются в участки де- 
струкции. Характерным рентгенологическим симптомом секвестра является выраженная интенсивность тени по сравнению с плотностью здоровой кости челюсти.

Клинико-рентгенологический анализ при посттравматическом остеомиелите нижней челюсти позволил различать ограниченные и диффузные гнойно-деструктивные процессы в кости без консолидации и при консолидации отломков.

Ввиду своеобразия строения нижней челюсти, по мнению Н.А. Рабухиной (1974), при посттравматическом остеомиелите в кости чаще образуются губчатые секвестры, а кортикальные бывают лишь при некротизации участка кости вблизи основания челюсти или компактной стенки лунки.

Перикоронит. На рентгенограмме нижней челюсти в боковой проекции зуб мудрости выявляется в неправильном положении по отношению к нижней челюсти и другим зубам. Он может быть наклонен коронкой вперед (упирается в зуб, стоящий впереди) или назад (упирается в передний край ветви нижней челюсти). При строго вертикальном положении зуб находится в инклюзии. При повторных обострениях на рентгеновском снимке в боковой проекции можно обнаружить резорбцию костной ткани между вторым и третьим молярами или позади коронки зуба мудрости в переднем крае ветви нижней челюсти.

По мнению Harniseh (1961) расширение перикоронарного пространства с дистальной стороны коронки зуба мудрости до 2 мм является физиологической нормой.

Переломы нижней челюсти выявляются на внутриротовых, обзорных и боковых рентгенологических снимках. Характеризуются нарушением целостности (непрерывности) костной ткани челюсти со смещением или без смещения отломков в различных ее отделах, с наличием или без наличия зуба в линии перелома. При переломах в области тела нижней челюсти линии повреждения наружного и внутреннего коркового вещества могут не совпадать между собой, что выявляется на боковых рентгенограммах (симптом раздвоения). Это создает ложное впечатление о наличии у больного оскольчатого перелома.

Рентгенологическое исследование височно-нижнечелюстного сустава позволяет определить:

- изменение ширины и формы суставной щели (сужение наблюдается при хронических артритах, артрозах, фиброзных анкилозах, при патологии прикуса; отсутствие суставной щели - при костном анкилозе, расширение щели - при остром артрите);

- изменение со стороны суставных отделов костей (изменение форм и размеров головки наблюдается при хроническом артрите и артрозе, врожденных аномалиях развития - синдром I и II жаберных дуг, гипоплазии и аплазии, при вторичных деформирующих остеоартрозах);

- состояние мягких тканей, окружающих сустав и ветвь нижней челюсти (оссифицирующий миозит). 


\section{Приложение 10.3. Показатели лейкоцитарной формулы}

При различных формах острых воспалительных заболеваний количество лейкоцитов в периферической крови может оставаться в пределах нормы, чаще наблюдается лейкоцитоз, количество лимфоцитов и моноцитов может оставаться без изменений или уменьшается, число эозинофилов несколько уменьшается.

Нейтрофилия (нейтрофилез) наблюдается при воспалительных заболеваниях, интоксикациях, кровотечениях, болезнях крови. Также приводят к нейтрофилии психоэмоциональные возбуждения (под действием физической нагрузки, холода, жары, при ожогах, при травме и т.п.) и др. Значительный нейтрофилез с гиперлейкоцитозом при резком ядерном сдвиге (до метамиелоцитов и миелоцитов) обычно наблюдается при тяжелом течении инфекционного процесса (сепсисе) при сохранении на достаточно высоком уровне общей сопротивляемости организма. Значительный нейтрофилез с небольшим лейкоцитозом свидетельствует о тяжелом течении септической инфекции при ослабленной сопротивляемости организма. Значительный нейтрофилез при лейкопении - показатель тяжелой инфекции и плохой сопротивляемости организма.

Сдвиг лейкоцитарной формулы влево - повышенное содержание палочкоядерных (юных) нейтрофилов и даже появление метамиелоцитов.

Сдвиг лейкоцитарной формулы вправо - повышенное содержание сегментоядерных (зрелых форм) нейтрофилов. По мнению М.А. Базарновой и Т.Л. Сакун (1982) сдвиг вправо встречается у 20\% здоровых людей. При ограниченных воспалительных процессах и инфекционных заболеваниях появление сдвига лейкоцитарной формулы вправо обычно указывает на благоприятное течение заболевания.

Токсическая зернистость нейтрофилов нередко появляется раньше ядерного сдвига. Это указывает на прогрессирование гнойновоспалительного процесса и на то, что возможен неблагоприятный исход.

Нейтропения встречается при вирусных инфекциях (грипп, корь, оспа, краснуха, гепатит) и при бактериальных инфекциях (брюшной тиф, паратиф). Нейтропения встречается также при железодефицитной анемии, анафилактическом шоке, тиреотоксикозе, гипотиреозе и др.

Эозинофилия (увеличение более 5-6\%) наблюдается при аллергических заболеваниях, паразитарных инфекциях, инфекционных заболеваниях (скарлатина). Встречается при кожных болезнях (дерматиты, экземы, пузырчатка). Злокачественные опухоли (особенно с метастазами и некрозом), болезни крови (лимфогрануломатоз, хронический миелолейкоз, полицитемия), облучение, саркоидоз, ревматизм и др., приводят к эозинофилии.

Эозинопения - при большинстве пиогенных инфекций, эклампсии, шоке, при снижении иммунной сопротивляемости организма. 
Базофилия - наблюдается при хроническом миелолейкозе, полицитемии, микседеме, хроническом синусите, реакции гиперчувствительности, хронической гемолитической анемии, лимфогрануломатозе и др.

Лимфоцитоз встречается при инфекционном мононуклеозе, гепатите, токсоплазмозе, туберкулезе, сифилисе (вторичный и врожденный), лимфолейкозе, лимфосаркоме и др. Даже встречается у практически здоровых людей. Правильно трактовать лимфоцитоз можно только с учетом клинических проявлений и показателей гемограммы.

Лимфопения - при инфекциях, лимфогрануломатозе, почечной недостаточности, иммунодефицитных состояниях, при воздействии на организм ионизирующей радиации, некоторых медикаментозных средств и др.

Моноцитоз - при инфекционном мононуклеозе, период реконвалесценции после острых инфекций, туберкулезе, сифилисе, саркоидозе, при воспалительных заболеваниях и др. Моноцитоз расценивают как показатель развития защитных процессов в организме, но только при условии увеличения абсолютного числа моноцитов (а не за счет нейтропении).

Моноцитопения - при апластической анемии и др.

По изменению количественных взаимоотношений форменных элементов крови, по мнению многих авторов, можно судить о тяжести течения и прогнозе острых воспалительных заболеваний.

У больных с челюстно-лицевой патологией (воспалительные заболевания, травматические повреждения и др.) наблюдаются изменения показателей обмена витаминов. В норме в сыворотке крови эти показатели следующие: ретинол (витамин А) - 1,05-2,27 мкмоль/л (300-650 мкг/л); тиамин (витамин В - 41,5-180,9 нмоль/л (в цельной крови); рибофлавин (витамин $\mathrm{B}_{2}$ ) - 33 нмоль или 0,5мкг/л (в цельной крови); пантотеновая кислота (витамин $\mathrm{B}_{3}$ ) - 4,7-8,34 мкмоль/л; холин (витамин $\mathrm{B}_{4}$ ) $1,27 \pm 0,32$ мг/л (в плазме), пиридоксин (витамин $\mathrm{B}_{6}$ ) - 14,6-72,8 нмоль/л (в плазме), фолиевая кислота - 3,9-28,6 нмоль/л (в плазме); аскорбиновая кислота (витамин С) - 34-114 мкмоль/л (в плазме), токоферол (витамин Е) - 5-20мг/л; липоевая кислота $-10-50$ мкг/л; парааминобензойная кислота (витамин $H J-20-700$ мкг/л (в цельной крови).

При гнойно-воспалительных заболеваниях челюстно-лицевой области наблюдаются изменения в анализах мочи. Протеинурия может быть при появлении белка в плазме крови, а затем и в моче, где появляются белки с небольшой молекулярной массой, свободно проникающие через нормально функционирующий клубочковый фильтр (белок Бенс-Джонса, миоглобин, гемоглобин).

Лейкоциты в моче здоровых людей обнаруживаются в количестве 4-6 в поле зрения. Их количество значительно увеличивается при высокой температуре тела (лихорадке), интоксикации, пиелонефрите и др.

Увеличенная концентрация мочевины в моче обнаруживается при повышенном содержании белка в питании, интенсивном распаде белков тканей, нефрите, интоксикации, лихорадке и др. 
Повышение уровня общего азота мочи наблюдается при рассасывании инфильтратов, при анаэробной инфекции, интенсивном распаде белка, диабете и др. 


\section{Приложение 10.4. Состав и свойства ротовой жидкости.}

Слюна. В состав слюны входят три пары слюнных желёз (околоушные, подъязычные и подчелюстные) и большое количество мелких желез, располагающихся в слизистой оболочке полости рта. В полости рта слюна превращается в так называемую ротовую жидкость. Попадая в полость рта, слюна смешивается с микроорганизмами, слущенным эпителием, а так же частичками пищи и превращается в ротовую жидкость,которая выполняет несколько функций: пищеварительную, защитную, минерализующую, свертывающую. Слюна смачивает слизистую полости рта, тем самым предотвращает ее высыхание и образование трещин. Полость рта является входными воротами для различного рода инфекций. Слюна, благодаря ферментам и иммуноглобулинам, осуществляет бактерицидные свойства, тем самым обеспечивая местный иммунитет. Слюна, омывая органы полости рта, очищает от остатков пищи и микробов, являющихся основной причиной возникновения кариеса. Слюна имеет слабо щелочную $\mathrm{pH}$ 6,87.0 или нейтральную реакцию. В сутки выделяется около 1,5 л слюны. Минерализующая функция слюны обеспечивается за счет большого содержания в ней микроэлементов, таких, например, как кальций, фосфор, магний, марганец и т.д., поступающих в основном с пищей и водой. Свертывающая система слюны обеспечивается за счет, так называемых тромбопластина, антигепариновой субстанции, протромбинов и т.д. Все эти вещества выполняют фибринолитическую и гемокоагулирующую функции. Именно поэтому в полости рта быстро останавливается кровотечение и все процессы регенерации проходят на много быстрее, чем где бы то ни было. Следует отметить наличие буферных систем, отвечающих за рН полости рта. Благодаря этим буферным системам, кислоты и щелочи в полости рта нейтрализуются, тем самым, кислотно-щелочной баланс приходит в равновесие.

Наиболее важные органические вещества слюны

\begin{tabular}{|l|l|}
\hline \multicolumn{1}{|c|}{ Гликопротеины } & \multicolumn{1}{|c|}{ Другие протеины } \\
\hline Макромолекулярный гликопротеин & Лизоцим \\
(ГП) & Лактоферрин \\
Катионный ГП & Альфа - амилаза \\
Анионный ГП & Статерин \\
Фосфорсодержащий ГП & \\
Секреторные компоненты & \\
Иммуноглобулин А & \\
Иммуноглобулин G & \\
Иммуноглобулин М & \\
\hline
\end{tabular}




\section{Функции слюны и её отдельных компонентов}

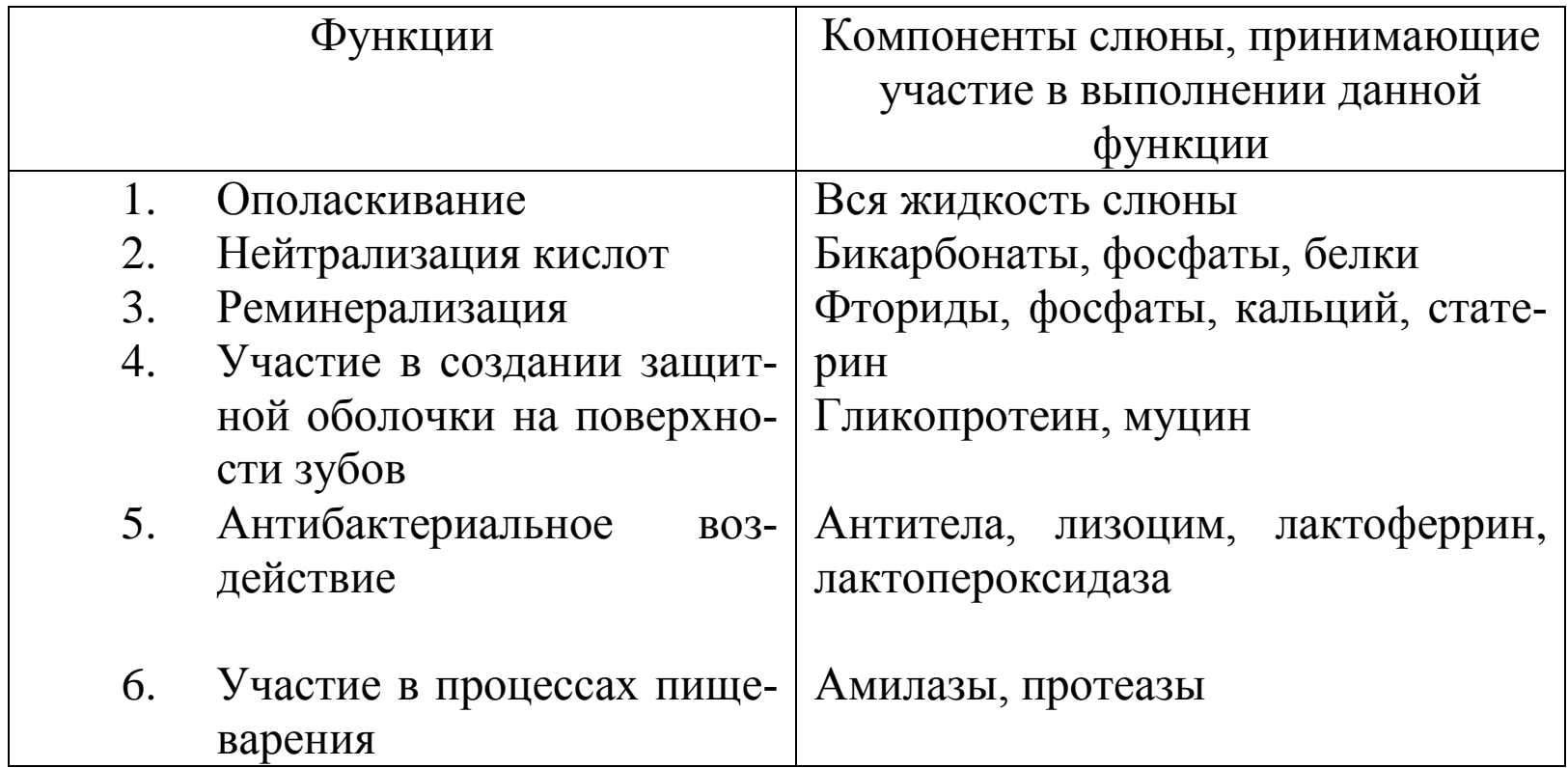

Скорость слюноотделения, значение $\mathrm{pH}$, буферная ёмкость слюны отдельных лиц в возрасте 15-55 лет. Представлены нормальные и очень низкие показатели.

\begin{tabular}{|c|c|c|}
\hline $\begin{array}{c}\text { Скорость слюноотделе- } \\
\text { ния, мг/мин }\end{array}$ & $\begin{array}{c}\text { Слюна в состоянии } \\
\text { покоя }\end{array}$ & $\begin{array}{c}\text { Стимулированная } \\
\text { слюна }\end{array}$ \\
\hline $\begin{array}{l}\text { Нормальная } \\
\text { Очень низкая }\end{array}$ & $\begin{array}{l}0,25-0,35 \\
<0,1\end{array}$ & $\begin{array}{l}1-3 \\
<0,7\end{array}$ \\
\hline Значения рН & & \\
\hline $\begin{array}{l}\text { Нормальная } \\
\text { Очень низкая }\end{array}$ & $\begin{array}{l}6,5-6,9 \\
<6,3\end{array}$ & $\begin{array}{l}7,0-7,5 \\
<6,8\end{array}$ \\
\hline $\begin{array}{l}\text { Буферная ёмкость слю- } \\
\text { ны }\end{array}$ & & \\
\hline $\begin{array}{l}\text { Нормальные конечные } \\
\text { значения рН } \\
\text { Очень низкие конечные } \\
\text { значения рН }\end{array}$ & $\begin{array}{l}4,25-4,75 \\
<3,5\end{array}$ & $\begin{array}{l}5,75-6,5 \\
<4\end{array}$ \\
\hline
\end{tabular}




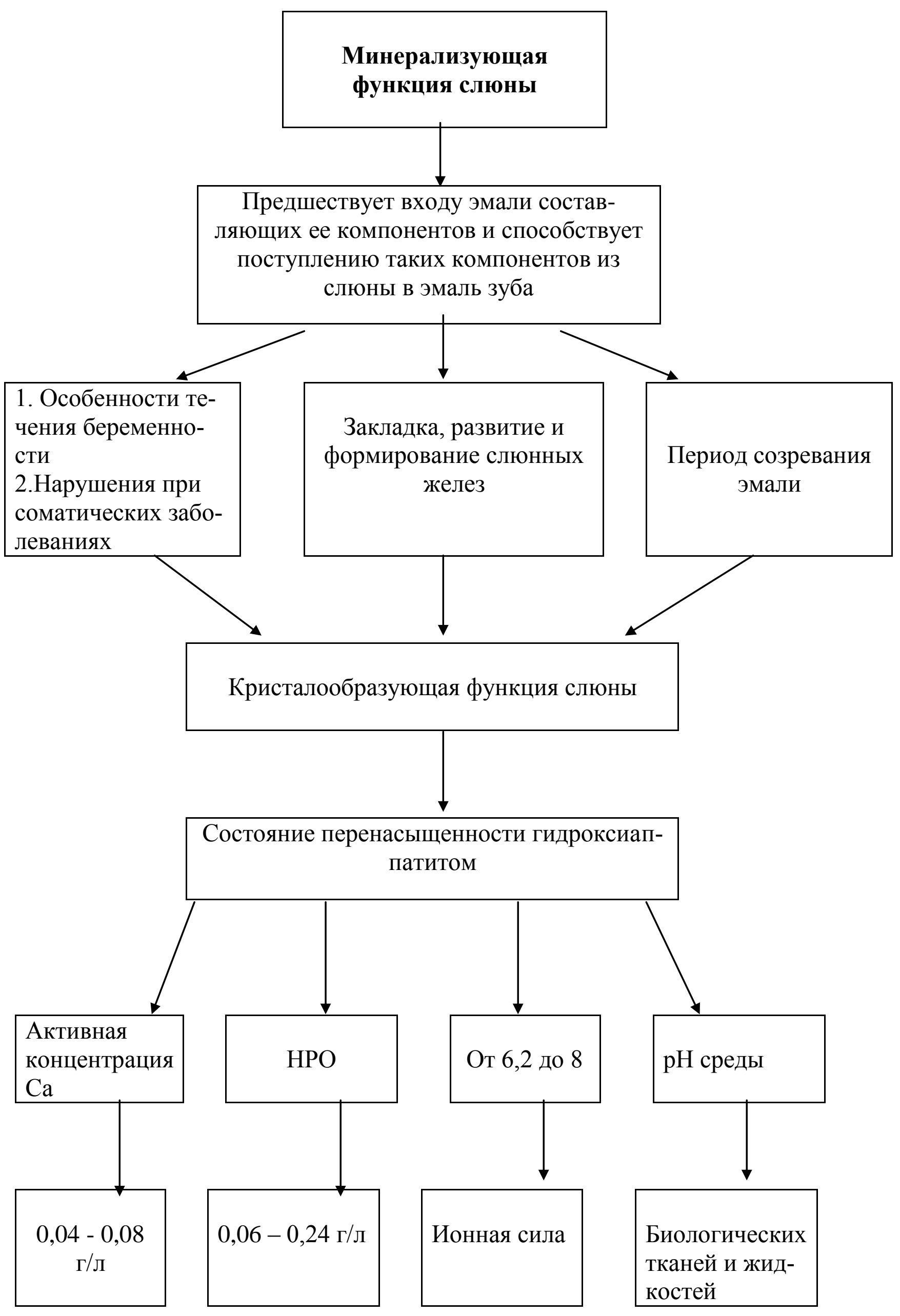


Слюна содержит многочисленные органические компоненты - протеины, углеводы, аминокислоты, ферменты, витамины и др.,основным из которых является белок. Количество общего белка в смешанной слюне составляет 0,8-3,0 г/л.

Различают следущие основные группы белков ротовой жидкости:

белки, богатые проливом, они связываются со стрептококками, связывают танины пищи и тем самым защищают СОПР от их повреждающего действия, придают вязкость слюне, способствуют созданию пелликулы зуба.

Белки, богатые гистидином, обладают бактерицидным действием,которые подавляют в микроорганизмах транспорт глюкозы и реакции гликолиза (Str. Mutans, Candida albicans)

Белки, богатые тирозином, препятствуют нуклеации и росту солей Са и Р, формирующих зубную эмаль, что обеспечивает защитное восстановительное действие для сохранения здоровых зубов.

Альбумины - большей частью попадают в слюну из десневой жидкости. Их количество возрастает при стоматитах, заболеваниях ЖКТ и других.

Гликопротеины слюны определяют вязкость.

Муцин - смачивает СОПР и зубы, защищает их от повреждения, способен адсорбироваться на поверхности зубов, образуя нерастворимую пленку. Обладает высокой вязкостью, эластичен,участвует в образовании пелликулы.

В смешанной слюне определяется активность более 10 ферментов, которые по происхождению делятся на 3 группы:

1) секретируемые паренхимой слюнной железы;

2) образующиеся в процессе ферментативной деятельности микроорганизмов;

3) образующиеся в результате распада лейкоцитов в полости рта;

Из ферментов слюны в первую очередь следует выделить аамилазу, которая уже в полости рта частично гидролизует углеводы, превращая их в декстрины, мальтозу и мальтазу.

Щелочная и кислая фосфатазы - отщепляют неорганический фосфат от органических соединений, их активность при воспалении мягких тканей полости рта и кариесе.

Нуклеазы слюны - РНК-аза и ДНК-аза, участвуют в расщеплении нуклеиновых кислот вирусов, что защищает организм от проникновения инфекционного фактора через полость рта.

Гиалуронидаза и каллекреин - изменяют уровень проницаемости тканей, играют важную роль в процессе поддержания нормального гомеостаза СОПР и твердых тканей зуба.

Лизоцим - термостабильный белок типа муколитического ферметна с относительной молекулярной массой от 1300 до 2500. Механизм бакте- 
риологического действия состоит в гидролизе связей $\mathrm{N}$-ацетилмурановой кислоты и $\mathrm{N}$-ацетилглюкозамина в полисахаридных цепях пептидогликогенного слоя клеточной стенки бактерий, в результате чего,изменяется её проницаемость, сопровождающаяся диффузией клеточного содержимого в окружающую среду.

Лактоферрин - конкурирует с бактериями за ионы железа и приводит к гибели тех, у которых развита система цитохромов.

Миелопероксидаза - в присутствии перекиси водорода, ионов хлора, брома, Йод встраивает ионы галогена в оболочки бактерий. Введение сильных окислителей в мембрану грамположительных и грамотрицательных бактерий приводит их к гибели.

\section{Иммуноглобулины слюны.}

Иммуноглобулины попадают в слюну из двух источников: в результате местного синтеза плазматическими клетками и из крови путем транссудации через десневой желобок, который является главным источником поступления лейкоцитов в полость рта.

Основном, местно образующимся, является $\boldsymbol{S}$ - $\boldsymbol{I g A}$,концентрация которого является показателем иммунобиологической реактивности. У него более высокая молекулярная масса в отличие от циркулирующей формы( $\boldsymbol{I g} \boldsymbol{A})$,вырабатываемой в лимфатической ткани. Механизм действия $\boldsymbol{S}-\boldsymbol{I g} \boldsymbol{A}$ на микроорганизмы заключается в том, что он активизирует альтернативным путем комплемент, что приводит к лизису микроба. $\boldsymbol{S}$ - $\boldsymbol{I g} \boldsymbol{A}$ препятствуют адгезии бактерий к эпителиальным клеткам, затрудняя их колонизацию в слизистой оболочке.Он образует комплексы с муцином.

Иммуноглобулин $\boldsymbol{M}$ находится в слюне в небольших количествах, синтезируется местно и избирательно секретируется. В отличии от $\boldsymbol{S}$-IgA он более лабилен в секретах желёз. У лиц с недостаточной выработкой $S$ $\operatorname{Ig} \boldsymbol{A}$ вкачестве компенсаторного механизма увеличена выработка $\boldsymbol{I g} \boldsymbol{M}$.

Иммуноглобулин $\boldsymbol{G}$ поступает из сыворотки крови через десневую жидкость, а также с секретом ОУСЖ. Абсолютное содержание $\boldsymbol{I g} \boldsymbol{G}$ может существенно изменяться при местных воспалительных процессах и увеличении сосудистой проницаемости. 


\section{ЛИТЕРАТУРА}

1.Алимская Е.А. Психопрофилактика в стоматологии // Новое в стоматологии. - 2002. - № 6 - С. 12-15

2.Бажанов Н.И., Гранин С.С. Обезболивание в поликлинической стоматологической практике. М.: Медицина. 1979. - 189 с.

3.Баум Л., Филипс Р.В., Лунд М.Р.: «Руководство по практической стоматологии».: пер. с англ. Кузьминой Э.М. - Медицина. 2005. - 679 с.

4.Барер Г.М., Лемецкая Т.Н. Болезни пародонта. Клиника, диагностика и лечение. М.; ВУНМЦ, 1996. — 86с.

5.Боровский Е.В., Грошиков В.К., Патрикеев. В.К., Барышева Ю.Д, Лемецкая Т.И. Терапевтическая стоматология / 3-е изд., перераб. и доп. М.: Медицина. 1982. - 560 с.: ил.

6.Боровский Е.В., Барышева Ю.Д., Максимовский Ю.М., Дмитрииева Л.А., Лемецкая Т.Н. Терапевтическая стоматология. 2-е изд. Испр. и дополн. М.:/ООО/ЛЛИА 1997 - 544 с.

7.Боровский Е.В. Терапевтическая стоматология М. 2005.- 450 с.

8.Боровский Е.В., Леонтьев В.К. Биология полости рта М.: Медицина. 1991. - $220 \mathrm{c}$.

9.Борисова Э.Г., Соловьёва С. Анализ ошибок и осложнений, возникающих в процессе работы врача стоматолога и приводящих к стоматоневрологическим заболеваниям. / Кафедра МГСМУ. 2010. - № 32. - С. 35-37

10.Быков В.Л. Гистология и эмбриология органов полости рта человека. / В.Л. Быков - 2-е издание, испр. - СПб.: Специальная литература. 1998. $248 \mathrm{c}$.

11.Егоров П.М., Карапетян И.С. Клиника и лечение болевого синдрома дисфункции височно-нижнечелюстного сустава. - М., Медицина. 1986 $125 \mathrm{c}$.

12. Григорьян А.С., Грудянов А.И., Рабухина Н.А., Фролова О.А. Болезни пародонта патогенез, диагностика, лечение. Руководство для врачей. М: Медицинское информационное агенство. 2004-320с.: ил.

13.Грошиков М.И. Некариозные поражения тканей зуба.- М., Медицина. 1985 -171c.

14.Давыдов А.Б. Диагностика и лечение карцином полости рта. - Тверь: ООО «Издательство «Триада», 2007. - 272c.

15.Евдокимов А.И. Руководство по хирургической стоматологии., М., Медицина, 1974.- 185 с. 
16.Золотко Ю.Л. Атлас топографической анатомии человека. М., Медицина. 1964.- т.1- 230 с.

17.Иванов В.С., Урбанович Л.И., Бережной В.П. Воспаление пульпы зуба. М.: Медицина. 1990. - 208 с.

18. Иванов В.С., Винниченко Ю.А., Иванова Е.В. Воспаление пульпы зуба. М.: Медицинское информационное агентство. 2003. - 264 с.

19.Иванов В.С Заболевания пародонта. 4-е изд. перераб. и доп. - М., «Мед.информ. агентство». 2001. - 300с.

20. Ивасенко П. И., Вагнер В. Д. Неотложные состояния в амбулаторной стоматологической практике. Издательство НГМА, Нижний Новгород. 2000. -86 c.

21.Карапетян И.С., Губайдулина Е.Я., Цегельник Л.Н. Предраковые состояния, опухолеподобные поражения и кисты лица, органов полости рта, челюстей, шеи. М., 1993.- 207c.

22. Копейкин В.Н. Ортопедическая стоматология: Учебник.-М: Медицина.1988. - 512с.

23.Клиническая оперативная челюстно-лицевая хирургия. Руководство для врачей. Под ред. проф. В.Н.Балина и Н.М.Александрова. 3-е издание., С-П, 1998.- 592c.

24.Коротких Н.Г., Морозов А.Н., Аникеев Ю.М. «Артроскопия височнонижнечелюстного сустава»: монография, Воронеж: Издательство Воронежского государственного университета. 2007. - 88c.

25.Коробкин В.А. Оценка эффективности и прогнозирование результата лечения больных раком слизистой оболочки полости рта и языка на основе многофакторного анализа с использованием данных проточной цитометрии /Дисс.д.м.н. Санкт-Петербург.1996.-536с.

26.Коробкин В.А. Диагностика хронических лимфаденитов челюстнолицевой области и шеи. Ленинград.1987.-160с

27.Кубрушко Т.В., Чесноков П.Е., Клименко Г.Я., Равинкин К.А., Хайн С.С «Управление эпидемиологической ситуацией и профилактикой патологий полости рта у подростков, проживающих в различных климатогеографических зонах»: монография, Воронеж:2009.-140с.

28.Кубрушко Т.В., Рыжова И.П., Милова Е.В. Современные диагностические и лечебные аспекты пульпита. Учебное пособие. Курск. 2011-151с.

29.Клинические ситуации с иллюстрациями. Учебно-методическое пособие для подготовки к итоговой государственной аттестации выпускников стоматологических факультетов медицинских вузов Российской Федера- 
ции. Ред. кол., отв. ред. Барер Г.М. М.: ГОУ ВУНМЦ МЗ РФ, 2008.-224с.: ил.

30.Лебедев А.А. Гончарова М.В. «Превентивная медицина-медицина XX1 века». Национальные проекты №12 (31) 2008 C 40-43) сайт Remedium.ru 31.Лукиных Л.М., Жулев Е.Н., Чуприна И.Н. Болезни пародонта. Нижний новгород: Изд-во Нижнегородской государственной медицинской академии. 2005.-322c

32Луцкая И.К. Руководство по стоматологии. Практическое пособие, Феникс. 2002. - С. 532

33.Леманн К.М. Основы терапевтической и ортопедической стоматологии: пер. с нем. / К.М Леманн, Э. Хельвиг; под ред. С.И Абакарова, В.Ф. Макеева. - Львов: Галл Дент. 1999. - 262с.: ил.

34.Леус П.А., Казеко Л.А. Особенности клинических проявлений рецессии десны. Минск. 1993.- 65с.

35.Marxkors R. Для самоопределения стоматолога / Новое в стоматологии. Научно-практический журнал-М. - №1/165/- 2010.- C.32-34www/newdent.ru 36.Международная классификация стоматологических болезней на основе МКБ-С-3-е изд. - Женева. 1997. - 248c.

37.Мюллер Х-П. Пародонтология . «ГалДент».Львов. 2004. - 256с.

38.Николаев А.И., Цепов Л.М. Практическая терапевтическая стоматология М МПИ 2003. - 542c.

39.Николаев А.И., Цепов Л. М. Практическая терапевтическая стоматология. - М.: Медпресс-информ.2000. - 453 с.

40.Новые образовательные и аттестационные технологии. - М.: ВУНМЦ. 2000. $-220 \mathrm{c}$.

41.Орехова Л.Ю., Кудрявцева Т.В., Осипова В.А., Бармашева А.А. Влияние сочетанных поражений осложнённого кариеса и воспалительных заболеваний пародонта на состояние зубочелюстной системы // Пародонтология. 2(31). 2004. - С. 8-14

42.Ортопедическая стоматология: Рук. для врачей, зубных техников, студентов стомат. фак. вузов и мед. Училищ / Н.Г. Аболмасов, Н.Н. Аболмасов, В.А. Бычков, А.Аль-Хаким. - Смоленск, 2000.-576 с.: ил.

43. Овруцкий Г.Д., Леонтьев В.К. Кариес зубов М: Медицина. 1986 - 143 с. 44.Пачес А.И. Опухоли головы и шеи. М., 1997.- 379c.

45.Пузин М.Н. Нейростоматологические заболевания. М., Медицина. 1997.- $230 \mathrm{c}$. 
46.Рабухина Н.А., Чупрынина Н.М. Ренгендиагностика заболеваний челюстно - лицевой области. - М.: Медицина. 1991. - 368c.

47.Рецессия десны. Эпидемиология, факторы риска. Принципы лечения: Метод. Рекомендации / А.М. Хамадеева, В.Д. Архипов, Д.А. Трунини и др.Самара1999.-47c.

48.Робустова Т.Г. Учебник хирургической стоматологии. Изд.3., М., 2000 $688 \mathrm{c}$.

49. Ронкин Константин Использование принципов нейро-мышечной стоматологии при реконструктивном протезировании пациента с патологией прикуса и дисфункцией височно-нижнечелюстного сустава (ВНЧС) Dental Market \#5 2006 C. $32-38$

50.Ронкин К. Мифы современной стоматологии с точки зрения положений нейромышечной концепции / Dental Market \#1 2010 C71 - 74

51.Ронкин К. Использование релаксации мышц головы и шеи с помощью миомонитора при ортопедическом или ортодонтическом лечении /Dental Market \#5 2009 C. 65-70

52.Рыбаков А.И., Иванов В.С. Клиника терапевтической стоматологии. 2-е изд. М.: Медицина. $-1980 .-320$ с. ил.

53.Рыжова И.П., Милова Е.В. Снижение атрофических процессов опорных тканей протезного ложа при ортопедическом лечении больных съемными конструкциями протезов. Материалы международной научно практической конференции «Стоматология Славянских государств» Белгород-2009, $296-300$ c.

54.Руководство по ортопедической стоматологии. Под редакцией Копейкина В.Н. М. Медицина. 2003. - 420 с.

55.Руководство по хирургической стоматологии и челюстно-лицевой хирургии. В 2-х частях. Под ред. член.-корр. РАМН. Безрукова В.М. и проф. Робустовой Т.Г., - М:. Медицина. 2000. - 1200с

56.Сагина О.В. Возможные пути развития государственной стоматологической помощи в России // Проблемы социальной гигиены, здравоохранения и истории медицины. М., 2005 - №6 С. 23-25

57.Соловьев М.М., Большаков О.П. Абсцесс, флегмона головы и шеи. С П. 1997. - $255 \mathrm{c}$.

58.В.М. Семенюк, В.Д. Вагнер, П.А. Онгоев. Ортопедическая стоматология в вопросах и ответах. - Москва: Медицинская книга. Н.Новгород: Издательство НГМА 2000. - 180с.

59.Справочик по стоматологии. Под ред. члена-корр. РАМН проф. В.М. Безрукова М. Медицина- 1998- 656 с. 
60. Струев И.В., Баркан И.Ю. Качественно - количественный метод определения мотивационного поля у стоматологических больных //Материалы XX I и XXII Всероссийских научно - практических конференций 2009. С. 29-30

61.«Стоматология» Учебник для студентов лечебного, педиатрического и медико-профилактического факультетов медицинских ВУЗов под ред. проф. Робустовой Т.Г., изд-во Медицина. Москва. 2008.- 525 с.

62.Тимофеев А.А. Руководство по челюстно-лицевой хирургии и хирургической стоматологии, 4-е изд., - Киев.2004-1062с.

63.Трезубов. В.Н. Ортопедическая стоматология (факультетский курс): Учеб. для студентов стоматолог. фак. мед. вузов /В.Н. Трезубов, А.С. Щербаков, Л.М. Мишнев; Под ред. В.Н. Трезубова. -6-е изд., перераб. и доп. - СПб.: Фолиант, 2002.-573 с.: ил.

64.Улитовский С.Б. Повышенная чувствительность зубов и качество жизни // Новое в стоматологии www.newodent. ru 2/166/2010. - С. 14-15.

66.Флетчер Р., Флетчер С, Вагнер Э. Клиническая эпидемиология. Основы доказательной медицины. М. Медиа Сфера, 3-е изд.2004. - 352c. (Пер. с англ.)

67.Хайман Смуклер. Нормализация окклюзии при наличии интактных и восстановленных зубов / Пер. А.Островского и Е. Ханина под ред. Н.И. Волосок, М.М. Антоник /Москва, С-Петербург, Киев, Алматы, Вильнюc.2006.-136c. www.dental-spa.ru

68.Хельвиг Э., Йоахим Климек, Томас Аттин. Терапевтическая стоматология. Перевод с немецкого под редакцией проф. А.М.Политун, проф. Смоляр Н.И. 1999. - 409 с.

69.Хватова В.А. Заболевания височно-нижнечелюстного сустава. М., 1982.-286c

72.Хватова В.А. Функциональная окклюзия в норме и патолгии.М.: Медицина. 1993. - 159с

73.Шаргородский А.Г. Воспалительные заболевания челюстно-лицевой области. М. 1985.-230c

74.Яковлева В. И. и др. Диагностика, лечение и профилактика стоматологических заболеваний.- Минск: Высшая школа. - 1994- 541с 
Издательство Курского государственного медицинского университета. 305041, г. Курск, ул. К. Маркса, 3.

Лицензия ЛР № 020862 от 30.04.99 г.

Тираж экз.

Отпечатано в типографии КГМУ.

305041, г. Курск, ул. К. Маркса, 3.

Заказ № 52. 


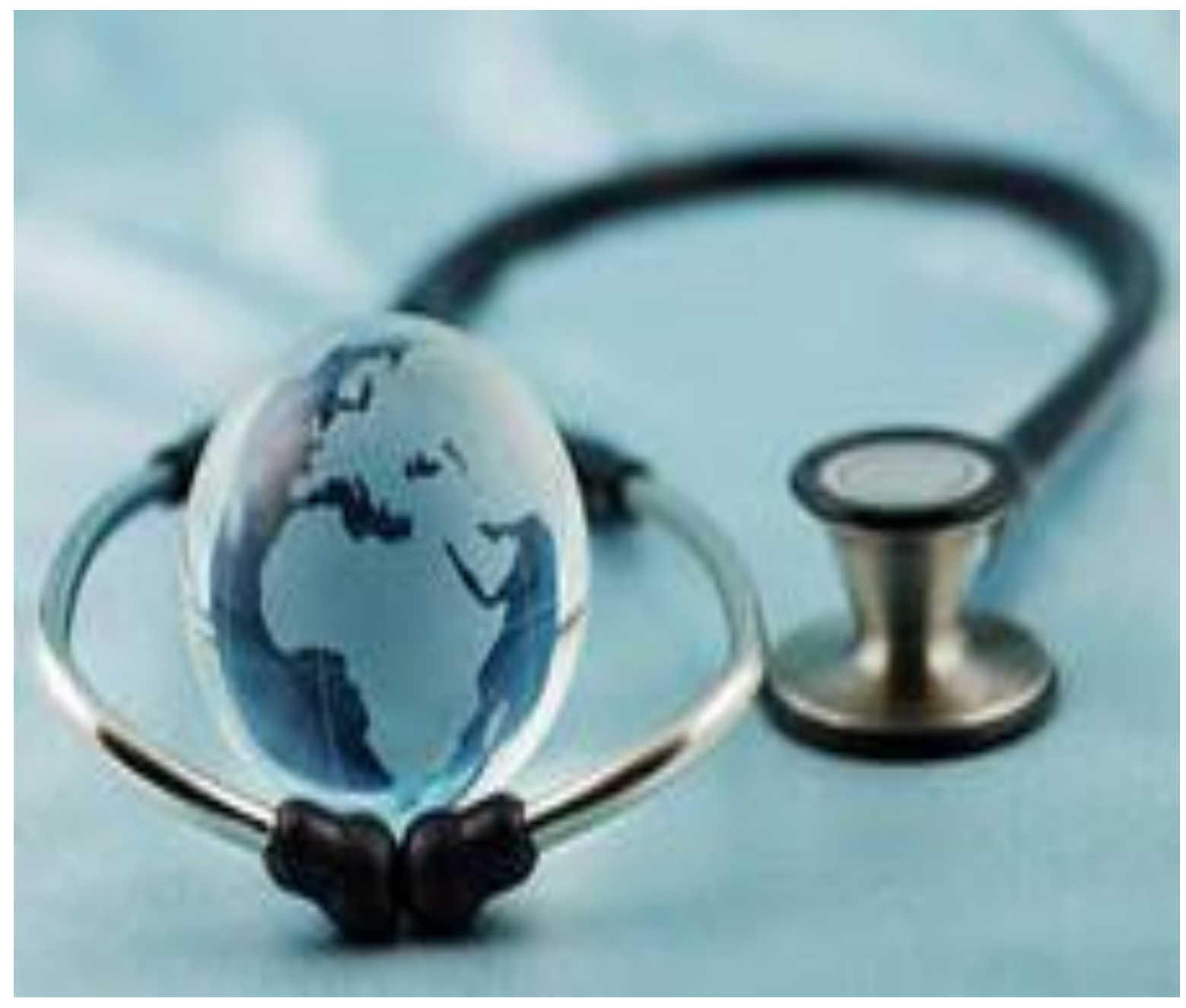

